\title{
POPULAR POLITICAL PARTICIPATION IN THE LATE ROMAN REPUBLIC
}

\author{
By \\ Claudine Lana Earley
}

\begin{abstract}
A thesis
submitted to the Victoria University of Wellington

in fulfilment of the requirements for the degree of Doctor of Philosophy in Classics
\end{abstract}

Victoria University of Wellington 
ABSTRACT

Roman democracy is in fashion. In particular, the publication of Fergus Millar's The Crowd in the Late Republic (1998) has stimulated debate on the democratic elements in Roman government during this period.

In this thesis I examine the nature of popular participation in the late Roman Republic. I focus on the decision-making power of the populus Romanus and popular pressure to effect reform in the favour of citizens outside the senatorial and equestrian orders. My findings are based on analysis of ancient literary and epigraphic sources, along with a critique of modern research on the topic.

The first chapter introduces the subject with a survey of current scholarly opinion and discussion of key concepts and terms. Chapter Two investigates how power was shared between senatus populusque Romanus and the distribution of power in the assemblies, concluding that participation was widespread as a result of the changing circumstances in the late Republic. As farmers and veterans moved to Rome, and slaves were freed and granted citizenship and the right to vote, the balance was tipped 
in the favour of the non-elite voter. Each class of the populus Romanus could participate in Roman politics, and certainly members of each did.

Having concluded my analysis of the formal avenues of participation, I move onto the informal. Chapter Three is the first of three chapters of case studies focusing on demonstrations and collective action which form the heart of this work. The first set of studies cover secession, mutiny and refusal of the draft. Chapter Four continues with studies of popular pressure to gain reforms to improve the food supply, restore tribunician power, obtain relief from crippling debt and land shortage. The final chapter of analysis, Chapter Five, investigates collective action at contiones, legislative assemblies, trials, ludi et gladiatores, triumphs, funerals, and elections.

The findings of these three chapters bring me to the conclusion that Rome was a democracy, if of a particular type. The nature of popular political participation in the late Republic resembled that of an emerging democracy with the non-elite gaining an increasing role in the decision-making process, albeit without constitutional definition. The citizens' right to participate in the formal assemblies was augmented by their ability to take part in less formal ways also. These informal methods ranged from popular involvement in contiones through to the application of pressure on senators 
through the threat of secession and mutiny. Only the rise of the principate, with formalised roles for the various sectors in society under one leader, brought these developments to an end. 


\section{ACKNOWLEDGEMENTS}

I owe my office mates over the years a debt of gratitude for their good company and patience. Thank you Mamari Stephens, Stephanie Head, Kosal Kong, Joe Sheppard, Jody Connor, Pippa Ström, Cynthia Werner, Simon Perris and Tania Hayes. And I must not forget those in the office next door who had their influence through the wall, especially Jayendra Chhana. Hannah Webling deserves to be singled out for her outstanding service to the postgraduates in the Classics programme. I would also like to thank Jeff Tatum for sending me his (then) unpublished chapter "Roman democracy?" and my supervisor Professor Art Pomeroy for his fine editing skills. I would never have been able to conduct my research without the help of the awesome interloans team at the university library and the generous scholarships offered by the university. Finally, I dedicate this to Aaron and our boys, whose affection, support and understanding encouraged me to complete this thesis. 


\section{CONTENTS}

$\begin{array}{ll}\text { Abstract } & \text { i }\end{array}$

Acknowledgements $\quad$ iii

Contents $\quad$ iv

CHAPTER 1: $\quad$ Introduction: Some kind of democracy? 1

CHAPTER 2: $\quad$ Senatus Populusque Romanus: 23

Power sharing between senate and people;

The distribution of power in the assemblies

CHAPTER 3: $\quad$ Demonstrations and Collective Action I: 102

Secession, mutiny and refusal of the draft;

The nature of popular demonstrations, their

leadership, organisation and composition

CHAPTER 4: $\quad$ Demonstrations and Collective Action II:

food supply, restoration of tribunicia potestas,

debt relief and agrarian reform

CHAPTER 5: $\quad$ Demonstrations and Collective Action III: 246

contiones, legislative assemblies, trials, ludi et

gladiatores, triumphs, champions, funerals,

elections, senatorial responses 
CHAPTER 6: $\quad$ Conclusion: What kind of democracy?

Bibliography

316 


\section{INTRODUCTION: SOME KIND OF DEMOCRACY?}

Popular political participation in the late Roman Republic took many forms.

The people voted in tribes to pass laws. Citizens gathered in centuries to elect consuls. The plebs refused the levy to secure new laws for debt relief. It is the purpose of this thesis to examine these formal practices and informal incidents in order to evaluate the nature of the democratic elements during this period. In this introduction, I will include a preliminary survey of political power in Rome, which will be continued in Chapter Two; a review of the latest scholarly opinions on the topic of the people's role in Roman politics; some reflections on the state of democracy today; and finally definitions of democracy and the people involved in the late Republican context.

The Roman people shared power with the senate. The Greek historian

Dionysius of Halicarnassus expresses the fundamentals of this powersharing arrangement:

We have had a law so long as we have inhabited this city by which the Senate is invested with sovereign power in everything except the appointing of magistrates, the enacting of laws, and the declaration or termination of wars; and the power of determining these three matters rests with the people, by their votes. (6.66.3) 
As Dionysius points out, Roman citizens decided who was invested with magisterial power, which bills became law and whether to begin or end conflict. These were the formal powers of the Roman people. I propose to assess the degree to which the people (populus Romanus) acted as the sovereign body of the late Roman Republic (ca. 133-50 BC), but will include episodes outside this period when they shed light on my analysis. ${ }^{1}$ The focus of my thesis will be on the level and effect of popular participation in both the formal side of the political process (especially elections and legislation) and the informal influence of the people on decision-making via demonstrations at public events and the contiones that preceded leglislative assemblies.

There is currently no agreement on the arena in which the people exercised more power. Jeff Tatum, for instance, holds that "the people exercised its powers only when it was articulated into one of the city's voting assemblies" for this was the only occasion in which they acted officially, ${ }^{2}$ while Moses Finley suggests that popular power was expressed through

\footnotetext{
${ }^{1}$ Analysis is best limited to this period because more sources from antiquity survive that were recorded during or shortly after the last 100 years of the Republic. See discussion below.

2 Tatum (2009: 4ff.). He finds the democratic element in the legislative assemblies but not the centuriate, whereas Yakobson (1999) argues that popular participation in electoral assemblies was significant and often decided the successful candidates. Based on the evidence of candidates' focus on winning over the wider popular strata and analysis of property classes, Yakobson concludes that the votes of the many did count.
} 
demonstrations and not assemblies, because magistrates dominated these and formal devices left little scope for popular participation. ${ }^{3}$ Much will turn on the way we choose to define "the people" and "democracy" (along with its cognates).

Millar's The Crowd in Rome in the Late Republic constitutes a preliminary study of the role of the people; my thesis will respond to Millar's conclusions which, among other things, equate public performance of politics with the existence of democracy. ${ }^{4}$ I am inclined to agree with Mary Beard and Michael Crawford who question Millar's findings on two accounts. First, they point out that public action does not necessarily mean democratic action. ${ }^{5}$ For this reason the following chapters include case studies of public action to assess its democratic elements. They also suggest that Millar broach the topic of population numbers, as we need to know how many participated before we can call a system participatory. ${ }^{6}$ While they make a valid point, recent efforts have revealed that it is nigh on impossible to make any progress on the hoary old subject of population

\footnotetext{
${ }^{3}$ Finley (1983: 86f., 91).

${ }^{4}$ Millar (1998).

${ }^{5}$ Similarly Mouritsen (2001: 46): “The fact than political proceedings are public does not in itself make them 'democratic'. That depends entirely on who attends them and .... on the relationship between the meetings and the political decision-making."

6 Beard and Crawford (1999: 90 f.). Cf. Millar (1998: 225).
} 
numbers, so this topic, although discussed in my thesis, is not a focus of my work.

I expect to find that popular opinion and pressure had a greater influence at the decision-making level of Roman government than previously supposed; there were democratic aspects in the late Republic. Popular power to influence decision-making increases in proportion to the limits placed on magisterial power.

Recent research has suggested that we reconsider the power dynamic of Roman politics. ${ }^{7}$ The unwritten Roman constitution, a combination of leges and iura tempered by mos and consuetudo (Cic. Leg. Man. 60), dictated that power was shared between the senate and people of Rome. Yet for a period classicists held that the elite controlled the state through clientela, ${ }^{8}$ so that power lay in the hands of the senate. Similarly, Claude Nicolet has argued that the strict hierarchy based upon property prevented the civic mass (as opposed to the "political class" or the timocratic oligarchy) from playing a direct role in politics. ${ }^{9}$ In response to such theories of senatorial dominance,

\footnotetext{
7 See especially Lintott (1999b: chh. 10 and 11).

8 A proponent of this view was Gelzer in his prosopographical The Roman Nobility, first published in 1912. The people and senate did, of course, have different spheres of influence, which will be a focal point of my analysis.

${ }^{9}$ Nicolet (1980).
} 
Fergus Millar has put the case for the sovereign power of the people, ultimately finding significant democratic aspects in the activities which took place in the Forum. ${ }^{10}$ His conclusions, however, require investigation: democracy does not necessarily result from popular sovereignty. In theory, citizens were meant to receive equal treatment before the law and equal political and civil rights. Yet, while some members of the Roman people were able to participate in the assemblies and meetings, the majority faced considerable hurdles. All citizens were permitted to take part in assemblies (with the exception of patrician exclusion from the concilium plebis), but factors such as failure to conduct a census and so enrol new citizens following the Social War, mobilisation of voters and distance from Rome affected the likelihood of participation.

The lower orders are often considered the victims of inequality in the late Republic - after all, it was they who struggled to survive, living hand to mouth. But the Roman judicial system disadvantaged the equestrian and senatorial orders more than the plebs. The very public trials of the elite exposed these members of the aristocracy to judgments based on political rhetoric. Many were condemned as a result of such unfair partisan practice. Also, when it came to capital punishment, political rights could be 
suspended if one was deemed a hostis; as we shall see, such treatment was applied to members of the elite as readily as to those more humble citizens.

Scholars have overemphasised the influence of the senate and patronage due to the elite bias of ancient (and more recent) sources. The elite body of the senate had undergone fragmentation in the 100 years preceding the demise of the Republic so that it no longer presented a cohesive body. The popular assemblies gained power as a result of competition between factions. Laws were no longer formulated by the senate as a whole, but by groups and even individuals, who used tribunician powers to secure the popular support necessary to pass their bills into law. Some were motivated by personal gain, such as material enrichment and political domination, while other groups and individuals had a popular political agenda, one that sought to benefit the people of Rome, the populus Romanus. ${ }^{11}$

\section{POPULAR PARTICIPATION AND DEMOCRACY}

"Democracy" and "democratic" are slippery terms, used by different people to describe very different regimes and phenomena. Some political theorists

${ }^{11}$ For the existence of political ideology at Rome, see Chapter Three below. 
consider democracy an "essentially contested concept" in that further specificity in definition rarely advances the topic. ${ }^{12}$ But I am skeptical of such cynicism. It will prove fruitful to investigate some concepts of democracy to advance an idea of popular participation and see where Rome of the late Republic fits in the spectrum. Will it be a different kind of democracy?

We are all familiar with the problems with today's deliberative democracies. ${ }^{13}$ Despite these shortcoming, some still measure the Roman system by modern standards, such as Morstein-Marx. He turns to Habermas to show how the Roman Republic fails to meet the standards of modern deliberative democracy because there was no equal access to decision-making and agenda-setting. ${ }^{14}$

Tatum evaluates the claim of Millar, Lintott and Yakobson that the Roman constitution contained democratic elements, or, as Lintott put it, was "some kind of democracy."15 The Roman people had power in practice. It is not

\footnotetext{
${ }^{12}$ Gallie (1964).

${ }^{13}$ On which see, for example, Talisse (2005).

${ }^{14}$ Morstein-Marx (2004: 22).

15 Lintott (1999b: 199-208) points out the obvious, viz. that Rome was nothing like democratic Athens, which he incidentally describes inaccurately as a world in which every male citizen enjoyed political equality and freedom of speech. It is clear that wealth and prestige counted in Athens as in Rome.
} 
enough for a state to possess the formal elements of democracy. After all, even totalitarian regimes have elections. Tatum refines his point:

the question is not whether republican Rome, either in theory or in practice, attained to contemporary standards of democracy (whatever they turn out to be), but rather, how, within the actualities of Roman society and the regular conduct of Roman political institutions, the people mattered to the actions of the governing class and to the decisions taken by the state. 16

It is this decision-making power that I will focus on. The Roman people had several means of influencing the way Rome was governed and the choices that were made. Popular pressure was ubiquitous. Robert Dahl has a definition of democracy that fits the context of the late Roman Republic: "a unique process for making collective and binding decisions". ${ }^{17}$

A good example of the semantic difficulties surrounding the term "democracy" can be seen in the work of the insightful ancient historian Moses Finley. In his examination of ancient and modern democracy, in which he compares the Athenian experience with that of the United States, he is critical of Rome in a footnote: what Romans had to say on democracy was derived from books and of little interest, since "Rome itself was never a democracy by any acceptable definition of that term, though popular

\footnotetext{
16 Tatum (2009: 14).

17 Dahl (1989: 5).
} 
institutions were incorporated into the oligarchical governmental system of the Roman Republic."18 Yet he later notes that the Founding Fathers set the US up as a republic, only to have it called a democracy by de Tocqueville and then the name to stick despite significant institutional changes. ${ }^{19}$

Majid Tehranian has provided an exhaustive list of elements fundamental to democracy, based on Lincoln's ideal of democracy as expressed in the Gettysburg Address ("government of the people, by the people, for the people"). Clearly the following summary is a wishlist seldom if ever achieved in sophisticated contemporary democracies let alone experimental early democracies such as those of classical Athens and Rome in the final generations of the Republic. Nonetheless, the following principles of political, economic, social and cultural democracy provide interesting criteria against which to measure the degree to which states promote and protect popular sovereignty and related rights and freedoms:

-political democracy: popular sovereignty; universal suffrage; protection of life, liberty, and pursuit of happiness; majority rule, minority rights; fair representation and periodic elections; peaceful succession; direct voting such as referenda on critical issues; rule of law, habeas corpus, bill of rights; and responsibilities of citizenship; economic democracy: protection of property; free markets; free competition; government regulation of trade and investment to ensure the absence of monopolies and fair standards in trade, exchange,

\footnotetext{
18 Finley (1985: 14).

${ }^{19}$ Finley (1985: 33)
} 
competition, health, and environment; -social democracy: social security for the unemployed, the retired, pregnant women, and children; the provision of public health, education and welfare; cultural democracy: universal education; access to means of communication; freedom of identity, including speech, assembly, religion, language, privacy, and lifestyle. ${ }^{20}$

Some theorists hold that democracy is a form of elitism: "the democratic method is that institutional arrangement for arriving at political decisions in which individuals acquire the power to decide by means of a competitive struggle for the people's vote." 21 This definition of the democratic method could be applied to Rome in the late Republic with interesting results: candidates for office competed for the vote in popular assemblies and, once elected, gained decision-making powers. But it is not a snug fit, for the popular power to legislate reduced magistrates' power as only the people could enact laws. In Rome, elected magistrates introduced bills, but did not vote on them except as members of a tribe, along with all other citizens. This is in contrast to contemporary deliberative democracies in which elected representatives vote bills into law. There is in addition a problem with the theory that elite politicians exercise overweening power when applied to contemporary democracies: it ignores the influence of the many between elections, including citizens approaching electorate representatives with problems, submissions and referenda. Ministers of Parliament do not

\footnotetext{
${ }^{20}$ Saikal and Schnabel (2003: 84 f.).

21 Schumpeter (1954: 269).
} 
isolate themselves from their electorate once elected. They must act responsibly and respond to requests and pressure from the citizens, or else face the consequences (e.g. Taito Phillip Field resigned from the Labour party after moves were made to expel him following allegations of improper use of his position and the resulting public outcry). ${ }^{22}$ Roman magistrates did not have to behave as well as this. Many examples exist of officials flouting their powers, but so too do instances of popular reaction to such bad behaviour. Consider the fate of Verres: his reputation was ruined once Cicero made public his allegation that Verres had executed a Roman citizen without trial. Also, the elitism theory relies on a coherent elite, whereas in reality competition within a fractured elite results in policy shaped by popular pressure, both in contemporary societies and in the late Roman Republic.

Another theory, espoused by Richard Mulgan, posits two sorts of democracy: restricted and unrestricted. The first is characterised by the existence of free elections and as such is too narrow and focused on representative democracy to be useful for our purposes: it leaves too little scope for citizen participation in decision-making which as we shall see was a fundamental facet of popular politics in the late republic. Unrestricted

22 NZ Herald Feb. 16, 2007. 
democracy, on the other hand, allows all citizens to have a say in the decision-making process. ${ }^{23}$ This unrestricted definition works when applied to New Zealand as, while the country is not a direct democracy - the people do not make decisions directly in a citizen assembly - there are nonetheless mechanisms through which public opinion can be accessed such as referenda and submissions. ${ }^{24}$ Indeed, the internet has promoted increased participation through web-based submissions. Mulgan notes the problems with this unrestricted definition also: government by the people, where all citizens have equal power, is an unachievable ideal. In the end, he chooses the following flexible definition: democracy is "the exercise of political power by the people," where "power" refers to all the ways in which one person may influence the behaviour of others. ${ }^{25}$ Majority rule is inevitable, although this does not promise the majority unrestricted rights; the primary aim ought to be consensus. Provided everyone is free to express their opinion and so has an equal say prior to the decision-making, that is democracy according to its own rules. Democracy also entails certain rights and freedoms: of speech and association, to vote and to information, but not limitless rights as may be promoted by certain liberal principles as these can

\footnotetext{
${ }^{23}$ Mulgan (1989: 16ff.).

24 Though note that popular influence has its limits: the interest group with the most financial backing can use advertising campaigns to hijack referenda.

${ }^{25}$ Mulgan (1989: 18).
} 
end up impinging upon more fundamental rights. ${ }^{26}$ Oddly, Henrik Mouritsen suggests there can be no truly democratic state as it is impossible to be fair to every citizen. ${ }^{27}$ Such a utopian state, I agree, has never existed and never will. There will always be clashes of interests. One person will feel disadvantaged because another has benefitted at their cost. Therefore this thesis will not be dealing with that sort of unattainable democracy.

In New Zealand, democracy is party-based, which brings its own problems. Disparity between parties, for instance, results at election time in substantially more funding going to established parties, thus disadvantaging the smaller and newer ones so that they find it difficult to publicise their policies. As a result these minor parties often rely on publicity via the major parties, as was the case when Jeanette Fitzsimons capitalised on Jenny Shipley's attempt to undermine her campaign in the Coromandel in 1999. In Rome, such inequalities did not exist.

DEMOCRATIC ELEMENTS IN THE ROMAN REPUBLIC

\footnotetext{
${ }^{26}$ Mulgan (1989: 20ff.).

27 Mouritsen (2001: 7).
} 
In a democracy, legal authority to make decisions lies with the people. Was this the case in Rome? A good place to start is Polybius, the Greek aristocrat from Achaea who was taken to Rome as a hostage. There he wrote an analysis of the Roman constitution, based on his experiences as a member of Scipio's inner circle. Polybius (6.11.11ff.) maintained that the Roman Republic in his day had a mixed constitution, made up of monarchic, aristocratic and democratic elements. ${ }^{28}$ The consuls symbolised the first, monarchic, aspect, with their power tempered only by the annual tenure and collegiality of the office. The second, aristocratic, element is provided by the senate which contained many of Rome's elite. The people of Rome, the populus Romanus, rounds off the three as the democratic part. Polybius emphasises that the people alone had the power to legislate (6.14.10). His analysis comes close to the Roman ideal of the senate and people governing the state together, only he extracts consuls from the senate and treats them as a separate category. Lintott suggests that Polybius believed Rome's mixed constitution was a good idea in principle, but in reality it was about to suffer at the hands of the aristocrats, who at the time had more influence than the

${ }^{28}$ Recent commentaries criticise Polybius for omissions and misconceptions. See Walbank (1957) for an explanation of how Polybius' account coheres with others. Walbank (1972: 155 f.) is more critical; Nippel (1980: 142-53) is also critical. Not surprisingly, Millar (1984) is less so. 
people, and were in the process of corrupting the people so that the populus would want "more than their equal part in the system". ${ }^{29}$

The separation of powers in Rome between magistrates, senate and people finds some parallels today in parliamentary democracies like New Zealand. The executive consists of the prime minister and his most senior ministers sitting in cabinet with its advisory role similar to that of the consuls and senior statesmen of the senate. The legislature is made up of the people's elected representatives sitting in parliament, and with the same legislative role as the tribal assembly in Rome. The judiciary finds it parallel in the praetors and juries of senators, equestrians and tribuni aerarii in the Roman context. In New Zealand, as in Rome, the separation of power is only theoretical. In practice MPs participate as both executive and legislators, just as in Rome there is a cross-over in the senators' roles as jurors and proposers of laws.

Polybius has a concept of the mixed constitution as founded upon the same principle as the separation of powers: by creating tension between different bodies they keep one another in check (6.18). ${ }^{30}$ Competition creates balance so that no one institution can act without the co-operation of the others, and

${ }^{29}$ Lintott (1999b: 23).

${ }^{30}$ Lintott (1999b: 24). 
so none comes to predominate. The same effect is achieved by the checks and balances present in both the Roman and New Zealand systems. For instance, the New Zealand public can call the government to account since elections are held relatively frequently: once every three years the people can elect a new government if they are unhappy with the performance of the old one. There were, of course, no political parties in Rome, yet the people could nonetheless punish a Roman magistrate who performed badly. He could find himself impeached at the end of his year in office ${ }^{31}$ and, if the people's memory was long enough, or hostile propaganda sufficiently thorough, his political career could be over. ${ }^{32}$

Popular authority to make decisions can take one of several forms. In Rome, we see citizens directly involved in politics, voting on laws without the intercession of any representative. In New Zealand, citizens elect representatives then sit back and, for the most part, let them make decisions on their behalf. ${ }^{33}$ If we call the latter a representative democracy, what might we call the Roman system? Jeff Tatum has suggested that Rome's was a "delegative democracy":

\footnotetext{
${ }^{31}$ For more on trials see Chapter Five below.

32 Compare the career-ending indiscretion of Graham Capill, founder of the Christian Heritage Party, found guilty in 2005 of sex charges.

${ }^{33}$ See below on the apathy of the contemporary New Zealand voting public.
} 
the political importance of the people, although significant, was clearly constrained. If, then, we must include the Romans' political system within the set of all democracies, we may prefer the denomination 'delegative democracy', in which system there is electoral competitiveness as well as civil and political freedom, all of which obtained in the Roman republic, but very little in the way of responsiveness to the preferences of the public on the part of elected magistrates, whose authority suffers few practical limitations. ${ }^{34}$

Tatum's emphasis on the lack of response on the part of magistrates to the opinions of those who elected them will be investigated in the case studies in the following chapters. Magistrates represented the interests of the people who elected them; consider the advice to Cicero that he appeal to the different interests of the different orders as consular candidate in the electioneering pamphlet Commentariolum Petitionis. And of course the tribunes of the plebs were known to act as representatives of the popular interest, as we shall see.

Popular power may seem reduced in a representative democracy when citizens concede their right to make decisions to office holders. Does democracy require equality of participation? New Zealand has a representative democracy, whereby the citizens exercise their sovereign power through elected representatives. This does not, however, necessarily entail a loss of power. The elected representatives and permanent

34 Tatum (2009: 19). 
government officials have the ability and resources to govern. This in itself may reflect some inequality of opportunity and the need for a redistribution of resources, but still the state needs those experienced in government to run the ship of state. This need not result in usurpation of popular power. People can still have equal political power even if less politically active than an MP or lobbyist. There are several means of exercising power through influencing representatives at national and local levels. For instance, citizens may communicate with parliament, the house of representatives, directly in the form of written submissions or by arranging to meet with MPs in person. The threat of withholding the vote at election time can also encourage MPs to adapt government policy following pressure from interest groups in particular.

The greatest challenge to the democratic spirit in New Zealand is not loss of political power to representatives but voter apathy. $79.46 \%$ of enrolled electors turned out to vote in the 2008 elections. ${ }^{35}$ Participation rates at general elections are relatively high, but at local body level fewer cast their vote. In 2001 only $45 \%$ of eligible voters took part in election of city councils. ${ }^{36}$ Some pundits have viewed abstention from politics as an

${ }^{35}$ http://www.elections.org.nz/news/2008-election-official-results.html accessed 11 July, 2009.

${ }^{36}$ Local Authority Election Statistics 2001, Department of Internal Affairs, Wellington 2003, p. 7. 
expression of tacit approval of the status quo. This theory, however, overlooks the possibility that some citizens do not participate because they lack the resources or ability to do so. Nonetheless equal political power is more important than equal political activity. As long as the opportunity exists for the less politically active citizen to take action in the political arena if the need is felt (eg. by taking part in a peace rally), then the decisionmakers remain vigilant and act in accordance with such anticipated reactions. ${ }^{37}$

At the same time, there exists a balance between rights and duties. You cannot demand rights without also performing duties for the state. There must also be a limit on individual rights to prevent one citizen from infringing upon the rights of another. In order for decision-makers to respond in a democracy with less active participants, citizens must be aware of their duties, which are necessary in order for decision-makers to respond appropriately. The people are sovereign and free but are obliged to fulfil their duties in return for this freedom. ${ }^{38}$

\footnotetext{
${ }^{37}$ Mulgan (1989: 43).

${ }^{38}$ Barber (1996: 285): “Civil society grounds democracy as a form of government in which not politicians and bureaucrats but an empowered people use legitimate force to put flesh on the bones of their liberties; and in which liberty carries with it the obligations of social responsibility and citizenship as well as the rights of legal persons."
} 
WHO WERE THE PEOPLE?

In order to discuss popular political participation in the late Roman Republic, we need first to define "the people". The populus Romanus "signifies the collective people, including, therefore, the senate", 39 unless the formulation is senatus populusque Romanus in which case the people includes everyone except senators. ${ }^{40}$ In other words, the populus was the equites and plebs; citizens of the equestrian order, that is those who belonged to the top property classis, and the rest, the plebs, who were registered in the remaining four classes. ${ }^{41}$

The term "populus" encompasses every adult male citizen. Women and noncitizens might form part of the informal crowd, but nowhere are they explicitly included in the populus. The Roman cives were a diverse bunch in the late Republic owing to a generous policy of enfranchisement of both exslaves and subjugated neighbours. ${ }^{42}$ Following the Social War, all those

\footnotetext{
${ }^{39}$ Lewis and Short "plebs" I.

40 Lewis and Short "populus" I. B. 1.

41 On property qualifications and classes see Livy 1.43.1-8; Dion. Hal. 4.16-17, 4.20.3-5, 7.59.2-

8; Cic. Rep. 2.39-40.

42 On citizenship see Sherwin-White (1973: 322-334).
} 
inhabiting the Italian peninsula south of the rivers Arno and Rubicon were enfranchised. These men made up the populus Romanus.

The plebs were all those citizens outside the senatorial and equestrian census-categories. Those who dwelled in the country were called "plebs rustica", while those in the city were termed "plebs urbana". Some were wealthy, others dirt poor.

These definitions of populus and plebs are not controversial, but when we try to further refine the definition of "people" we encounter problems, due in most part to the rhetorical nature of one of our main sources, Cicero. In his speeches, the meaning of populus Romanus changes to suit his purpose. In the first speech he delivered against Rullus' land bill in 63 BC, Cicero was directing his words to the senate and so characterised the populus as those who valued pax, concordia and otium (Leg. Agr. 1.23). These priorities of peace and harmony echo those of the equestrians as described in the Commentariolum Petitionis (53), which suggests that men from an equestrian background may have formed the core of his supporters in the senate, although it must be admitted that by the year of this speech, there was enough tension in the air that an appeal to pax, concordia and otium no doubt had universal appeal. The second speech he delivered against Rullus was in the forum before a contio, not in the senate house. This time though his 
audience were not senators but whoever was present in the forum, whether by chance or by conscious effort.

This was Cicero's first contio as consul, hence his show of gratitude to the people for supporting his candidature (2.1-4). But this also gives us reason to suspect that his audience was predominantly one of loyal supporters, ${ }^{43}$ notified of the event in advance. They were those who would vote on the bill, so in this speech we find the populus taking on a "tribal" sense, defined in terms of rural and urban tribes (2.79). In another speech, this time in defence of Rabirius, he includes in the united front that defended Rome against Saturninus every type of citizen in order to give a sense of unity, although he does not use the Latin populus: senators, equites, tribuni aerarii and "ceterorumque ordinum omnium homines" (Rab. perd. 27).

In another example, Cicero distinguishes populus from plebs as a rhetorical flourish in the speech he composed in defence of Murena in 63 BC. He hoped his defence would turn out gloriously both for himself and his office, and for plebs and populus (Cic. Mur. 1.1). ${ }^{44}$ Cicero did not usually

\footnotetext{
${ }^{43}$ Thus Mouritsen (2001: 55).

${ }^{44}$ Lewis and Short "populus" I. B. 2: Livy 2.56; Cic. Mur. 1.1; Leg. Agr. 2.27. See Nicolet (1980: 225, 304).
} 
differentiate between the two, so we should not read too much into this distinction.

The sources may also complicate our analysis by vague references to those whom they are discussing. Livy for instance sometimes uses the term "plebs" indiscriminately, even when the context suggests that he is referring to the wider populus, that is all men of both humble and more than moderate means. He uses the term plebs generically. The trick is to refine the identity of his subject from the context. For instance, when he discusses the levy, we should expect the plebs in this case to refer to males of military age.

Ancient authors' choice of terms to describe a section of the population was based not on objective criteria, but was more a reflection of style and individual moral standpoint. Hence some might seek to avoid repetition, while others expressed their attitude towards different sections of society. Analysis of terms in the context in which they are used is thus crucial. ${ }^{45}$

${ }^{45}$ As pointed out by Yavetz (1969: 7). Many terms occur in connection with the participants in demonstrations and other collective action, such as: plebs, multitudo, populus Romanus, equites, hippeis, ochlos, plethos, demos, politai, homilos, polloi, libertinorum et servorum manus, gladiatores, fugitivii, cives imperiti, cheirotechnai, falcarii, tabernarii, opifices, servitia, xenoi, monomachoi, therapontes, improbi, homines, milites, stratiotai, hopla, liberi, servi, egentes, tota Italia and omnes ordines. 
The term "crowd" has negative connotations of which we need to be aware. And yet the crowd (variously termed turba, multitudo, vulgus) that frequented the forum and so too contiones need not necessarily have excluded members of the first property class. These men had time on their hands, and likely had the political nous to take an interest in proceedings. The Commentariolum Petitionis (37-38) provides further evidence on the constitution of the multitudo: the writer emphasises his concern that the candidate have a multitudo about him, and this is no humble crowd, but one consisting of those he had successfully defended, namely men of property and reputation worth saving. ${ }^{46}$

What follows is an examination of collective action and the practice of assemblies and magistrates. I will analyse ancient literary sources, namely histories, biographies, speeches delivered before the people in the Forum and the senate in the curia, as well as letters and inscriptions for evidence of elite attitudes toward the people and popular attitudes to political participation. Developments from early Rome will be traced using Livy and Dionysius of Halicarnassus. Evidence from the principate can also be used with care. One characteristic of ancient literary sources often interpreted as problematic can, in fact, help us reconstruct the past. Historians, especially

${ }^{46}$ Morstein-Marx (1998: 260f.) has successfully defended the reliability of the Comm. Pet. 
Livy, have been criticised for unconscious retrojection of their own contemporary realities, which means that despite having lost his books covering the late Republic, we can glean evidence of this period from his work on earlier times. Along with this examination of ancient material, I will analyse recent political analysis of the late Republic.

Chapter Two investigates the balance of power between senate and people, along with the distribution of power in the popular assemblies. Chapter Three is the first of three chapters containing the case studies on demonstrations and collective action that form the heart of this work. The first set of studies are on secession, mutiny and refusal of the draft. Chapter Four continues with studies on popular pressure to gain reforms to improve the food supply, restore tribunician power, obtain relief from crippling debt and land shortage. The final chapter of analysis, Chapter Five, investigates collective action at contiones, legislative assemblies, trials, ludi et gladiatores, triumphs, funerals, and elections.

\section{CHAPTER 2: SENATUS POPULUSQUE ROMANUS}

Popular participation was fundamental to the workings of the Roman Republic. State institutions incorporated and relied upon the people's involvement and the voting of the legislative assemblies and election of magistrates were both based on the ethos of the sovereignty of the Roman 
people. The citizens reigned supreme in these arenas. The populus Romanus in the broadest sense, including citizens from every strata of society, had an integral role in decision-making to the extent that the people's sanction was needed before a bill passed into law. The success of a candidate for the honour of office-holding depended on his winning the support of those citizens who could afford the time and expense to attend the elections held in Rome annually. When it came to elections, it was up to the candidate to utilise his networks to make himself more appealing than his competition. In the case of legislative assemblies, mobilisation of the voting populace depended on rousing their interest in the issue being put to the vote.

Despite claims to the contrary, ${ }^{47}$ Romans had plenty of opportunity to participate and so exercise political power in the formal mechanisms of government, that is the voting and elective assemblies, as we will see in this chapter. The people also exercised power through demonstrations, secessions, and riots, the subject of my next three chapters.

The citizens of Rome shared the power to make decisions with the senate. The abbreviation SPQR expresses the principle of joint rule. ${ }^{48}$ The Roman

${ }^{47}$ Finley (1983: 91 f.), for example, believes most never had the chance to vote.

48 The acronym stands for "senatus populusque Romanus" (Cic. Planc. 37.90) or "Romani" (Cic. Phil. 6.2.4). Inscriptions preserve the formulae "senatus populusque Romanus" (ILS 72, 81, 83, 112, 216, 24411, 264, 265, 294, 302, 314, 729, 772, 794, 1243, 3090, 3326, 3780, 5386, 
constitution, that is the rules of political operation based on law and tradition, dictated that the senate and people of Rome were together sovereign. They ruled Rome together. The ideal relied on compromise as a means of preventing conflict between senate, people, and factions consisting of elements of the two groups. Sallust expresses the ideal, although not the reality, when he tells us that

before the destruction of Carthage the people and senate of Rome together governed the republic peacefully and with moderation. There was no strife among the citizens either for glory or for power; fear of the enemy preserved the good morals of the state. (BJ 41.2)

Livy portrays more realistically the tension between those who had the loudest voice in the senate and the opinion of those who spoke for the tribal assembly:

When four tribunes of the plebs vetoed this bill [which gave citizenship with the right to vote to the inhabitants of Formiae, Fundi and Arpinum] on the ground that it was not proposed with the sanction of the senate, they were informed that it was the prerogative of the assembly, not the senate, to bestow franchise. (38.36.8-9) ${ }^{49}$

8744a5), “senatus p. q. R." (ILS 296, 298); “senatus p. R.” (ILS 342), “s. p. q. R.” (ILS 82, 255, 274, 292, 309, 341, 374, 425, 694, 698, 769, 797, 798, 799, 1707, 3174, 3781, 3802), "[se]natus et populus Romanus" (ILS 136), "senatus ac populus Rom." (ILS 771) and "senatus amplissimus populusq. Romanus" (ILS 809). Sallust reverses the order, putting the people first: "populus et senatus Romanus" (BJ 41.2), as does Livy: "populi Romani senatusque verbis" (7.31.10; 24.37.7) and ILS 15: "populus senatusque Romanus".

${ }^{49}$ For more on the popular erosion of senatorial authority following the precedent of the Gracchi see Brunt (1988: 32-35). 
This passage illustrates the battle for power between the two public bodies in 188 BC. Here the senate, as represented by pro-senatorial tribunes, and a popular tribune disagree over the correct political process. At the very heart of the debate in 188 was the issue of respecting senatorial auctoritas - the body ought to be consulted before a bill was presented to the assembly out of respect for the prestige of the senators. This conflict between senatorial auctoritas and popular libertas is a continuing theme of the late Republic

Before we can examine further the people's share of decision-making power, we need to first consider who were are talking about. The senate and people were by no means homogenous groups, despite the impression given by Sallust in his famous statement regarding the decline of good relations between senate and people after the fall of Carthage: "The nobilitas began to abuse their dignitas and the populus their libertas... Thus the community was split into two parties (partes), and between these the state was torn to pieces" (BJ 41.5). The senate was indeed composed of factions, but these continually shifted as men changed alliances to suit their latest need. The career of C. Marius most clearly illustrates this tradition.

Sallust's nobilitas was not only composed of factions, but also consisted of men from diverse backgrounds. The oligarchy was made up of the senate and magistrates, that is those of at least equestrian ranked families who 
chose a political career, a career in public office. Curule magistrates were elected by the centuriate assembly, the rest by the tribal assembly. After the reforms of Sulla, quaestors gained entry to the senate and stayed there unless they fell victim to the censors' quinquennial revision of the senate. Freedmen were eligible for equestrian rank if their property qualification was sufficient, so sons of such wealthy freedmen were able to stand for office, although there existed a ban on freedmen themselves canvassing for office. ${ }^{50}$

Non-senatorial aristocracy, that is members of the equestrian order who had not entered the senate, also enjoyed political influence through their connections with magistrates and senators and were for this reason considered part of that ruling elite, or oligarchy. One of the most influential equites was Cicero's friend Atticus, to whom Cicero wrote regularly seeking advice. This was one of the traditional relationships between senator and equestrian. Other members of the equestrian order, such as publicani, might turn to a senatorial friend for help with the completion of public contracts, as Crassus' clients did in 60-59 BC. In the late Republic, however, some equites became more active in the service of both plebs and senate, as we shall see.

50 Treggiari (1969: $64 \mathrm{ff}$. ), with the caveat that the elevation in status occurred only rarely. 
Popular influence differed from that of the oligarchy as it was not so easily concentrated in factions. Sallust attributed the people's failure to take on the senate to the plebs' lack of unity: "The nobilitas had the more powerful factio, while the vis plebis was less effective because it was dispersed and divided among many" (BJ 41.6). The historian is right to emphasise the lack of concentration of vis in the hands of one sector of the populus. Unlike senatorial authority, where one or two powerful cliques might sometimes have dominated senatorial decision-making, this would never be the case with the people. The populus Romanus in the late Republic included citizens from every section of society except senators: equites, farmers, craftsmen, day labourers, soldiers, senators and newly enfranchised freedmen and inhabitants from throughout the Italian peninsula all contributed to the citizen body, the populus Romanus. It was not possible to organise so many disparate groups into factions along the lines of those of the senate, a far smaller body, although some tried. ${ }^{51}$

This chapter tests the truth of the theory that the people and senate together made the decisions which affected Rome and her land empire. Central to the following chapters is an analysis of this decision-making power in the

\footnotetext{
51 At times it seemed like the entire peninsula was divided along factional lines, e.g. during the tension between Marius and Sulla, Catiline and Cicero, and Pompey and Caesaer.
} 
form of a comparison of the motives, interests and aims of the varied groups of citizens plus the techniques the groups used to achieve their goals.

POWER

Power is the ability to affect decisions and can be divided into influence and authority. Influence comes with the threat of sanctions, used in such a way that men follow the suggestion of the influential because of their auctoritas or prestige gained from all areas of their life. Authority, on the other hand, means commands are obeyed because the individual or group has the sort of respect that demands obedience, as is the case when governments follow the dictates of public opinion. Another form of power exists when people adapt their actions based upon anticipated reactions. Thus, in contemporary democracies like New Zealand, the people exercise power without realising their sovereignty, because Members of Parliament (MPs) and government officials moderate their actions in accordance with what they perceive the desires of the constituency to be. In this sense, then, people need not participate in politics in order for their needs and desires to be fulfilled, although such passivity only works if their representatives 
understand fully the people's needs and desires. Anticipated reactions can have negative results. ${ }^{52}$

As we have seen, the power to make decisions was shared by both the senate and people of Rome. But the amount of power possessed by each, and the nature of that power, varied. ${ }^{53}$ The exclusion of some citizens from membership in rural tribes, in particular recently enfranchised free and freedmen, made the voting clout of citizens with rural registrations stronger than those crammed into the four urban tribes. This is just one of the limits placed on the power of some citizens. ${ }^{54}$ Different sectors of society had different spheres of influence. The question of who had the power is also complicated by the fact that the theory as espoused by ancient writers is often contradicted by the reality found in the case studies to follow.

So who had what power in the late Roman Republic? Dionysius of Halicarnassus has consuls explain the division of areas of responsibility between senate and people in the fifth century BC:

52 Mulgan (1989: 33 f.) gives the example of some capitalists unfairly influencing government decisions, potentially with neither government nor capitalist aware.

${ }^{53}$ The reasons for the fluctuating strength of popular power are examined in the chapters that follow.

54 See Brunt (1988: 23-27) on the limits placed on popular power. 
We have had a law so long as we have inhabited this city by which the senate is invested with sovereign power in everything except the appointing of magistrates, the enacting of laws, and the declaration or termination of wars; and the power of determining these three matters rests with the people, by their votes. $(6.66 .3$; cf. $7.56 ; 9.37 .2)$

Although his account is slightly anachronistic in its attribution to the people of the power to enact laws (plebiscites did not gain the force of law until 287 $\mathrm{BC})$, the popular power to elect magistrates and decide to go to war persisted into the late Republic. The senate, meanwhile, made rulings on everything else, namely foreign affairs and treasury matters.

Sallust, on the other hand, downplayed the people's role and instead claimed that the Republic was oligarchic with a few men responsible for decision-making, the people too disorganised to have any real effect: "Affairs at home and in the field were managed according to the will of a few men, in whose hands were the treasury, the provinces, public offices, glory and triumphs. The people were burdened with military service and poverty" (BJ 41.7-8; cf. Cic. Sest. 137). So too he might have believed modern representative democracies to be oligarchic for the same reasons, especially if we use Athens in the time of Pericles as a model for democracy. The citizens of today's democracies do not participate directly in politics. Instead, twenty-first century democracies have constructed vast bureaucracies staffed by non-elected public servants to allow their citizens 
time free from politics; they have heads of state, presidents and prime ministers to guide policy and make the ultimate decisions, whereas Athens was acephalous. An oligarchy is visible in the executive branch of parliament in contemporary New Zealand. It is inevitable that a few office holders (and indeed non-elected officials in government departments) make the decisions, and so, in this sense, democracies are oligarchic.

Further comparison with Athens highlights how democracy has evolved. Today officers of state are elected, whereas Athens used a lottery system (except for the appointment of strategoi); the franchise is now shared (though with degrees of liberality), while in Athens citizenship was closely guarded, restricted to a male birth elite. In New Zealand, Sallust might struggle to recognise the government as democratic: the ideal of the active, publicspirited citizen present in classical Athens has all but vanished, kept alive by only a handful of politically active "trouble-makers." 55

The Roman constitution had a mixture of monarchic, oligarchic and democratic elements which saw power shared amongst three groups:

${ }^{55}$ Recent protests at the closure of the pay and employment equity unit at the Labour Department attracted a small crowd of two hundred participants at parliament on June 30, 2009 (http://www.stuff.co.nz/dominion-post/news/politics/2553043/Pay-equity-protestat-Parliament, accessed 2 July, 2009). 
consuls, senate and people.56 As Polybius noted (6.12.1-8), there were monarchic aspects to the consular imperium. Today there is disagreement over the degree to which the consuls' imperium was all-powerful. ${ }^{57}$ They certainly summoned the comitia centuriata and senate, controlled the approach of embassies, set the agenda for senate meetings and performed its decrees. But their imperium was limited by annual tenure and collegiality, to prevent the domination of any one man. Polybius tends to exaggerate the influence of consuls, ignoring praetors' powers to run Rome's senate and assemblies in the consuls' absence. Such delegation of duties detracted from the consuls' power. In addition, praetors had their own sphere of responsibility in the courts, where they were responsible to no consul yet wielded impressive juridical powers. ${ }^{58}$ Similarly, aediles had their own area focused on the supervision of Rome's roads, marketplaces, and so on. Certainly, a consul as commander of an army had the power to execute his soldiers without a trial. But he still had to answer to the senate; again Polybius exaggerates, this time regarding the consuls' control of finance, giving the impression that he could draw money at will when in fact the senate controlled the supply.

\footnotetext{
56 Brunt (1988: 13-23) evaluates the relative powers of senate, magistrates and the people.

57 Brunt (1988: 15-18) and Lintott (1999: 17f.), for instance, disagree with Polybius over the extent of consular powers and note their limits.

58 On praetors, see Brennan (2000).
} 
The senate's powers extended to control of the treasury, authority in Italy over crimes of treachery, conspiracy, poisoning, and assassination, and the right to send and receive embassies (Polyb. 6.13). In this way, the senate possessed executive power beyond that of a mere advisory body. And yet, senatorial power was limited in several ways. For instance, magistrates could limit the power of colleagues and lesser magistrates with their veto.

Lily Ross Taylor is one modern scholar who has argued for oligarchic hegemony. She claimed that magistrates had the power handed down by tradition to influence elections, legislation and the selection of juries. In both centuriate and tribal assemblies the presiding magistrate

could report omens and dissolve the assembly when he did not like the way things were going, could refuse to accept candidates for office (a power better attested for the centuries than for the tribes), could put men of his choice in empty tribes, and could influence the vote through the custodes he appointed. 59

These magisterial powers not withstanding, the strength of the populus Romanus to get their man elected is illustrated in their choice of office holders. In times of popular discontent, the people would elect men ready to defy the senate, such as Clodius. The people also secured commands via

59 Taylor (1966: 83). 
legislation for their favourites, such as Scipio Aemilianus and Marius, thus stealing the prerogative for allocation of provinces from the senate.

Another hold the people had over the senators was institutionalised bribery: competition at elections was so fierce that candidates had long been compelled to gift money to electors, originally to members of their own tribe, but ultimately to all and sundry. The donations did not, however, usually buy an election victory: the practice was so widespread that all candidates were expected to participate. Q. Aurelius Symmachus, a senator during the $4^{\text {th }}$ century $A D$, reflects upon the improved situation in the Empire:

To challenge the present, let antiquity produce the tribes smeared with freedmen and the plebeian scum; we call upon the patricians. Let it conjure up the distributors of electoral bribes; we call upon the emperors. We understand very well the blessings of our age: the hideous voting tablet, the crooked distribution of the seating places in the theatre among the clients, the venal urn, all of these are no more! The elections are transacted between the senate and the emperors: equals elect equals, and the final decision rests with the superiors (Or. 4.7). ${ }^{60}$

Similarly Cicero believed senators were buffeted about by the random favour of the people. He complains that the people does not vote for the best candidate but

${ }^{60}$ Quote from Linderski (1985: 87). 
promotes those who court it most assiduously (facit eos, a quibus est maxime ambitus); and even if after all it does give a deliberate verdict, that verdict is determined, not by a discriminating wisdom, but frequently by impulse and a spirit of headstrong caprice. For the multitude is a stranger to deliberation, to reason, to discernment, and to patient scrutiny. (Planc. 9)

He continues, explaining that the people decided the outcome of elections:

It is the privilege of free peoples, and above all of this people, whose conquests have given it paramount sway over the whole world, that by its votes it can bestow or take away its offices as it likes. We too have our part to play; tossed as we are upon the stormy billows of popular favour, we must bear contentedly with the people's will, win it to ourselves when it is estranged, grapple it to us when we have won it, and pacify it when it is in turmoil. If we set no great store by its rewards, we are not called upon to do it homage; but if we set our hearts upon them, we must not grow weary in courting its favour. (Planc. 11)

Cicero advises a man who considered he ought to win the aedileship due to his ancient and illustrious lineage, but was frustrated by a lesser opponent who canvassed more energetically (valde ambiendum), that "the people would retort by reminding you of its established usage and ancestral precedent; it would point out that it has always desired to be asked, and to be approached in suppliant guise" (Planc. 12). Members of the nobility, no matter how prestigious their family, nonethless had to seek popular support.

Just as the populus decided who won election to office, they also had power over the actions of magistrates. Once in office, magistrates had to behave 
within certain boundaries or else face impeachment once their tenure was over. They were not only subject to the dictates of the senate, but they also had to answer to the people for fear of court action. ${ }^{61}$ Even after the establishment of standing courts during the second century $\mathrm{BC}$, with juries composed of men from the equestrian and senatorial orders, the people's influence was felt during trials. ${ }^{62}$

The people conferred power and meted out punishment through the justice system. The trial of magistrates took place before juries of equestrians ${ }^{63}$ and those facing capital punishment were tried before the centuriate assembly. Polybius (6.14) also notes in passing that the people could make and repeal law, elect magistrates, declare war and peace (although in practice this was done by the commander in the field), and make alliances. The people had power over the consuls in that the latter relied on popular support to secure the passage of bills through the tribal assembly. The same was the case for men facing prosecution in court (Polyb. 6.15). Similarly, the people could limit a magistrate's powers by legislation (Polyb. 6.16.2-3). Tribunes acting

\footnotetext{
61 Brunt (1988: 20; 341f.).

62 See Chapter Five.

63 Sometimes the equestrian juries were replaced by senatorial ones, as ocurred following Sulla's reforms for instance.
} 
on behalf of the people could also flex their popular muscles via their veto, thus negating any other magistrate's proposal.

Popular authority also becomes more noticeable in the area of legislation, where we find bills passed against the will of the senate, as was the case with Flaminius' agrarian law of 232, the lex Claudia barring senators from commerce of 218, and Gracchan laws on holding public land, conscription and the ballot. Indeed, Tiberius Gracchus' successful intervention on behalf of the people in the case of Attalus' bequest in 133 illustrates that the people were able to override senatorial auctoritas and make decisions in areas that were usually the domain of the senate. ${ }^{64}$

Following Sallust (Hist. 1.12; BJ 41), a theory has developed that the people made their voice heard more clearly under the influence of the Gracchi because, prior to the brothers, the people had been preoccupied by foreign wars and had lacked determined leaders. ${ }^{65}$ By the time of Caesar, popularis politicians had learnt from their predecessors how to secure the popular support needed to win elections and get bills passed into law. Dio claimed

\footnotetext{
${ }^{64}$ Brunt (1988: 32) notes that in this case Tiberius "asserted the sovereign right of the people to take decisions without the prior sanction of the senate."

65 Brunt (1988: 21).
} 
that Caesar "courted the good-will of the multitude, observing how much stronger they were than the senate" (36.43.3).

Despite acknowledging these popular powers, others join Taylor in questioning their strength, holding that "the people's share in power was largely specious", 66 a claim that will be tested in the following pages. Similarly, it has been suggested that the people did not constitute a governing body, and so had less power in comparison to the senate as a result. ${ }^{67}$ This theory, however, supposes that the senate did form a governing body, which is arguable, especially when we take into account the lack of coherence, general disposition towards competition, and their subservient position to magistrates and, as we shall see, the people of Rome.

For example, Sulla's attempt to reduce popular power in 88 , by banning tribunes from legislating, reveals that the people did indeed have enough power to make him nervous despite the alleged pre-eminence of senatorial authority. Sulla tried to increase the power of the senate by limiting that of the tribal assembly, yet his attempt was unsuccessful due to popular backlash. After he marched on Rome in 88, Sulla and his colleague Q.

\footnotetext{
${ }^{66}$ Brunt (1988: 15; 324 ff.).

67 Tatum (2009: 4ff.) refers to the senatorial order as the "governing class", and believes the people only had power when acting in one of their assemblies.
} 
Pompeius Rufus announced two new rules to the people: firstly they revived the procedure whereby the senate considered any bill before it was put to the people to vote on and, in a flashback to the days before the lex Hortensia, they stipulated that the voting be in centuries, not tribes. Appian (BC 1.59) explains that these modifications to legislative procedure were designed to put an end to civil discord because decision-making would be removed from the hands of the poor and reckless, and vested instead in the "well-to-do and sober-minded", and tribunes' power, which had become tyrannical according to this source, curtailed. Whatever Sulla's justification, he failed to convince the people. Nor did he persuade his lieutenants of the benefits of his new system; Pompey was behind the eventual reversal of the reform. The people's response to this reduction of their power will be investigated in Chapter Four below. 


\section{EXERCISE OF POWER AND ELIGIBILITY}

I will focus on the two areas in which power is exercised through political institutions: legislation and election of magistrates. Before we analyse cases of popular action in the following chapters, we need first to evaluate the relative power of the vote of the populus, that is the universus populus, in the centuriate and tribal assemblies. In so doing, we will test Taylor's hypothesis that the populus had more power to legislate than to elect higher magistrates, ${ }^{68}$ alongside Yakobson's belief that "the importance of the popular element in [the electoral] system was far greater than is often supposed." 69 After analysing the formal procedure and theoretical limits of power in each, I will turn to the actual practice of popular participation in the late Roman Republic, including involvement outside official institutions which nonetheless afforded elite and non-elite alike the opportunity to take part in civil life, by attendance at funerals, triumphs, demonstrations, festivals, the theatre, trials and lawsuits, and by escorting magistrates and those canvassing for office. Indeed, Claude Nicolet has suggested that these alternate forms of civil life dominate the official forms in the late Republic. ${ }^{70}$

\footnotetext{
68 Taylor (1949: 61f.; 1960: ix) argues that the plebs urbanus had greater influence in the legislative tribal assemblies, while the greater influence in elections was to be had by those resident outside Rome.

69 Yakobson, (1999: 11f.).

70 Nicolet (1980: 345).
} 
But first, we must consider who was eligible to participate in politics. The inhabitants of Rome and the Italian peninsula could participate in elections and legislation. Citizenship was granted freely relative to other ancient societies (perhaps because initially those involved were all inhabitants of the Latium plain and so no geographical barriers distinguished communities). However, only men born free (ingenui) or freed from slavery (libertini) were eligible and degrees of citizenship existed especially with regard to libertini. $^{71}$ No women or slaves could participate (although we do find influential women and slaves in elite households). In the early Republic censors divided the citizens or populus into census groups according to wealth based on property ownership. ${ }^{72}$ Census qualifications prevented the poor from standing for office and so barred them from taking part in politics as magistrates.

Until the reforms of the third century, patricians enjoyed more power than plebeians. The origin of the distinction between patrician and plebeian is shrouded in the mists of time. Nonetheless, the division between patrician

\footnotetext{
71 Cicero says that "servos denique, quorum ius, fortuna, condicio infima est, bene de re publica meritos, persaepe libertate, id est civitate, publice donari videmus" (Balb. 24). See below for more on the status of libertini.
}

72 Yakobson (1999: 44ff.). 
and plebeian families was rigorously enforced so that originally only patricians could be magistrates. Gradually the plebeians gained representation in the senate, in the first instance by the election of tribuni plebis in $493 .{ }^{73}$ In 471 the comitia tributa won the right to elect plebeian magistrates and the number of tribunes was raised from two to five (Livy 2.55.10-58.2; Dion. Hal. 9.43-49). In 447 it earned the right to elect quaestors (Tac. Ann. 11.22). In 449 plebeians obtained important legislative duties via the Valerio-Horatian laws, which stipulated that plebiscites had the force of law, as long as they had senatorial sanction (Livy 3.39-41, 49-64; Dion. Hal. 11.4-6, 19-24, 38-50). By 287 plebiscites gained independent validity over the whole populus not just the plebs (Livy Per. 11; Plin. NH 16.37). This was maintained except for a period during which Sulla required senatorial approval of plebiscites before they were put to the vote after he instituted various other restrictions on the powers of tribunes. ${ }^{74}$

There is some disagreement about why the patricians shared power with the plebeians. Until recently the consensus was that plebeians applied pressure by withdrawing from Rome in times of peril, thus leaving the patricians in the lurch and encouraging concessions. Mitchell challenged the existence of such secessions by suggesting there never was a "struggle of the orders,"

\footnotetext{
${ }^{73}$ See $M R R 1.16 \mathrm{n} .1$ for the competing traditions regarding the number of tribunes.

74 Taylor (1960: 47); see Chapter Four.
} 
although he has not received much encouragement. ${ }^{75}$ In effect, most citizens were plebs and so formed the majority, and thus were crucial members, of the Roman army. The army flexed its muscle in the fashion of the hoplites in seventh century Greece when they demanded political power in return for military duties: the aristocrats were compelled to allow those wealthy enough to afford the hoplite armour to participate in government. The Roman soldiers sought representation in the form of plebeian magistracies and increased participation via assemblies in exchange for increased military responsibilities. ${ }^{76}$

As Rome's conquered territory increased in the Italian peninsula, so too did the number of her Italian allies, many of whom were obliged to serve in Roman armies by way of the levy (dilectus), although they served in separate allied auxiliary contingents. ${ }^{77}$ Roman assidui (property owners, mostly small farmers) provided most of the Roman manpower, but were fewer in number than the Italian allies who made up as much as two thirds of the army until

\footnotetext{
${ }^{75}$ Mitchell (1990).

76 See Chapter Three on how popular pressure brought change in the people's favour.

77 See Brunt (1971a: 545-548) on the formula togatorum which decided how many allies were levied. Brunt concludes that it is impossible to reconstruct the exact formula, but that we know enough to conclude that something short of a full levy of allied iuniores was the practice.
} 
the first century BC (Vell. Pat. 2.15.2). ${ }^{78}$ The situation had changed by the late Republic, by which time volunteers began to constitute a significant, yet debatable, proportion of the troops. ${ }^{79}$ Similarly controversial is the claim that those Romans serving under Caesar, largely members of the proletariat, received pay and so were wholly professional. ${ }^{80}$ Nonetheless, soldiers carried a lot of weight at elections, as we can see when Cicero asks the jury about the influence of milites at elections:

Do these things appear to you trifling supports and aids towards obtaining the consulship? Is the good-will of the soldiery a trifle? who are both intrinsically powerful through their own numbers, and also by their influence among their connections, and who in declaring a consul have great weight among the entire Roman people. (Cic. Mur. 38)

Freedmen, foreigners, soldiers and farmers were all eligible to vote once enfranchised, as a result of the state's generous policy of enfranchisement.

\footnotetext{
${ }^{78}$ Brunt (1971a: 677-686) reckons the ratio of allies to Romans in armies between 225 and 90 $\mathrm{BC}$ was roughly 2:1, depending on the martial situation. The ratio changes following the Social War as Rome's Italian allies became citizens, although I would suggest Roman expansion around the Mediterranean provided a supply of non-Italian allies. Brunt does not provide analysis of ratios after $90 \mathrm{BC}$.
}

${ }^{79}$ Compare the contention of Nicolet (1980: 91) that volunteers made up the majority of Rome's legions after 106 BC to Brunt (1988: 253) who holds that Marius' reform in 107 did not create an army of volunteers because the property qualification was already so low that there was scarcely any difference between the rural assidui and the urban proletariat volunteers. The state had been for some time supplying gear to the poorer rustic soldiers and deducting the cost from pay. Also, the number of urban volunteers was much smaller than those conscripts or volunteers from the countryside.

80 Nicolet (1980: 117). Cf. Brunt (1988: 260): conscripts and volunteers fought together, and Brunt consistently contends that the urban proletariat formed only a tiny fraction of the armies. Caesar did however double the soldiers' annual stipendium to 225 denarii (Brunt, 1988: 262). 


\section{LEGISLATION}

Popular power is most clearly demonstrated in the legislative ability of the people. Despite repeated and varied attempts to prevent the popular will succeeding, "the last century of the Republic is replete with examples of laws proposed or carried in conformity with popular demands against the will of the senate". ${ }^{81}$ Instances of popular legislation in conflict with senatorial interests date back to the third century BC, following the passage of the lex Hortensia giving plebiscites the force of law. The Gracchi showed the people how much power they had to effect change in their favour, and from the period of their reforms until the end of the Republic popular influence was felt throughout the empire. Popular legislation decided who commanded the army, as was the case in 88 when the people decided that Marius should usurp Sulla as commander against Mithridates, and so voted in favour of Sulpicius' bill to give him command (App. BC 1.57; Livy Per. 77). ${ }^{82}$ The people also passed a law allowing Caesar to stand for the consulship in absentia and retain his command until the time that he would

\footnotetext{
81 Brunt (1988: 27), with examples of techniques used to obstruct the will of the people: tribunician veto, religious impediments, and a law designed to "annul statutes passed in violation of specified conditions for their validity".

82 Although Sulla overturned this popular decision, had he been more law abiding, the people's choice would have remained in command.
} 
become consul. Caesar claimed in $49 \mathrm{BC}$ that he was crossing the Rubicon in defence of the people's tribunes, whose vetoes the senate was illegally overriding, and in defence of the people's right to legislate, a reference to this law (Caes. BC 1.1-9, 22, 32).

A common criticism of the legislative sphere is that the people merely enacted laws rather than shaped them in any way. ${ }^{83}$ This theory we will deal with below. In addition, some hold that senatorial decrees amounted to laws. Alan Watson goes some way in refuting this theory when he considers the legal value of senatus consulta and concludes that they did not create law in the late Republic because senatorial decrees were just recommendations and, based on an analysis of the implications of the evidence from the period, the senate did not consider it was making law when it passed decrees. A senatus consultum of $186 \mathrm{BC}$ requested that the consul should put it to the tribunes of the plebs that they propose to the concilium plebis that P Aebutius and Hispala Faecenia be granted certain rights (Livy 39.19.4-5). ${ }^{84}$ In 58 BC the same principle was followed. Cicero reported to his brother: "senatus consultum factum est ut sodalitates

\footnotetext{
83 Scullard (1959: 8).

${ }^{84}$ Watson (1974: 29).
} 
decuriatique discederent lexque de iis ferretur, ut qui non discessissent ea poena quae est de vi tenerentur" (Q. fr. 2.3.5). ${ }^{85}$

Before we deal with the above instances in more detail, it will pay to outline the voting procedure during the late Republic. ${ }^{86}$ Two assemblies met regularly in the late Republic: the comitia centuriata (centuriate assembly) and the concilium plebis (plebeian assembly). The first assembled to elect the highest magistrates (consuls, praetors, curule aediles and censors). The Roman people also met in centuries to declare war and conclude peace, and to judge capital cases. The concilium plebis met to elect lesser magistrates (tribunes of the plebs, quaestors and plebeian aediles), to legislate, and increasingly to elect, recall, and extend the command of generals, to conclude peace and also, perhaps, to declare war. ${ }^{87}$ There was a third assembly, the comitia tributa (tribal assembly), in existence during the late Republic, but due to its similarities in form and function to the concilium

${ }^{85}$ For more see Watson (1974: Chapter 2).

86 See Taylor (1966) with examples from primary sources. Also Lintott (1999b: 43-49). See Cornell (1995: 378-380) for the typical scholarly take on how the organisation of the assemblies gave the greatest influence to the propertied class and discriminated especially against the urban proletariat and peasants smallholders further from Rome. Cornell's analysis is fair and balanced in that he at least acknowledges the democratic elements preceding the changes just before $300 \mathrm{BC}$.

87 Sandberg (2001: 138 with n. 25) gives tentative support to Fascione's thesis that it had become part of the tribe's regular business to declare war, although he admits that there is only one piece of evidence and this is from 383 BC: 'omnes tribus bellum iusserunt' (Livy 6.21.5). 
plebis it is difficult to distinguish the two. Some have suggested that the tribal assembly had only a nominal existence, and there were no meetings of the tribes other than concilia plebis. But this theory has been rebuffed by Andrew Lintott who has provided evidence for meetings of tribal assemblies presided over by curule magistrates. ${ }^{88}$ There was one striking difference between the two, namely that patricians were banned from participating in the concilium plebis, although they were permitted to attend any contiones, as these were not official assemblies. This exclusion, however, had little effect in the late Republic, for by that time patrician families, always in the minority, had now almost completely died out. ${ }^{89}$ In addition, exclusion from voting need not have prevented patricians from entering the Forum and pressing their fellow tribesmen to vote in their favour. ${ }^{90}$

One of the most important democratic elements in the late Roman republic, this legislative function of the concilium plebis is an example of popular power. The challenge will be, however, to work out the extent to which senatorial and magisterial checks and balances, along with vestigial timocratic elements in the voting units in the two assemblies, influenced not

${ }^{88}$ See Lintott (1999b: 53f.) for detailed discussion.

${ }^{89}$ Witness Caesar's attempts to revitalise patrician clans by creating new families.

90 Taylor (1966: 61f.). See Gellius (15.27.4) for patricians forbidden to participate in legislative assemblies and Livy (5.30.4-7) on patricians circling the Forum in an effort to influence the vote of their tribules. 
only the legislative process but also the voting clout of individual citizens. I will analyse first procedure and participation in the concilium plebis, then the comitia centuriata.

\section{CONCILIUM PLEBIS}

The magistrates may have dominated formal aspects of the plebeian assembly, but Millar has shown that just because an office holder could summon an assembly, it does not mean that he could expect the voters to agree with him. Rome's political leadership needed to win over the people in order for laws to be passed. The bill's proposer (rogator) literally talked the audience in the Forum into supporting his proposal at informal public meetings (contiones). As Cicero put it, in a speech delivered to the people at one such contio, "your influence resides in your votes" (Leg. Agr. 2.102). The vote of the citizens in their tribes decided the matter. Decisions made in the senate were thus only confirmed once the people had been persuaded to support the bill. ${ }^{91}$ While the people lacked the initiative to introduce bills, they could nonetheless reject them. Although we only know of a few

${ }^{91}$ Millar (1998). 
instances of such rejection, the shortage of evidence makes it impossible to draw conclusions as to the regularity of the occurrence. ${ }^{92}$

Since 287 BC, when plebiscites gained the force of law and thus became legally binding on both patricians and plebeians alike, tribunes of the plebs introduced bills before the citizens assembled in their tribes to be voted into law. The concilium plebis was based on tribal organisation. Rome had been divided into geographically determined tribes by the penultimate king, Servius Tullius in the mid-sixth century BC. By the late Republic there were thirty five tribes, four urban and thirty one rural, ${ }^{93}$ membership of which was largely determined by domicile, ${ }^{94}$ although each tribe was no longer necessarily a contiguous geographical unit. For as Rome acquired new territory in the Italian peninsula, at first new tribes were created, but after 241 BC the number of tribes was set at 35 and newly enfranchised communities were added to pre-existing tribes, sometimes quite a distance

92 Flaig (1995: 80) suggests that the people seldom rejected a bill because rogatores made sure they had the necessary popular support at contiones to have it passed in to law. Tatum (2009: 12f.) contends instead that the exceptions prove the rule: few examples survive due to an abitrary accident of the historical record, the fragmentary nature of the sources. He suggests the failure of bills was not so rare, as a negative leaves little or no trace (unless Cicero had a hand in the defeat of a bill as we will see).

93 The four urban tribes were Suburana, Palatina, Esquilina and Collina. The 31 rural tribes were Romilia, Pollia, Maecia, Menenia, Aemilia, Aniensis, Arnensis, Clustumina, Claudia, Cornelia, Camilia, Fabia, Falerna, Galeria, Horatia, Lemonia, Oufentina, Pomptina, Papiria, Pupinia, Poblilia, Quirina, Scaptia, Sabatina, Sergia, Stellatina, Tromentina, Teretina, Velina, Voturia, Voltinia. The seminal work on tribes is Lily Ross Taylor's The Voting Districts of the Roman Republic Rome, 1960.

94 For exceptions to the rule of registration according to place of residence, see below, especially as regards freedmen. 
from the original tribal territory, which resulted in an odd patchwork of tribal distributions over the peninsula. The Pollia, for instance, had its tribal units spread far and wide following the enfranchisement of the Italian allies after the Social War. ${ }^{95}$

All assembly activity relied on the initiative of the presiding magistrates. Magistrates decided which candidates stood for office (though they prevented very few men qualified from standing). They proposed laws which those assembled could not amend, only accept or reject. But the predominance of office holders is a practical expedient and exists even now in western democracies, with government ministers the prime movers behind bills. ${ }^{96}$ Moreover, the magistrates responsible for passing legislation included tribunes of the plebs, and these ten representatives of the plebs offered ample opportunity for diverse issues to be initiated. ${ }^{97}$

The contio (public meeting) opened every assembly: the magistrate sponsoring the bill (rogator) addressed the people, as did those whom he

95 Taylor (1960: 274). She also provides a map at the end of this volume on voting districts which illustrates the spread of the tribes after the enfranchisement of most of Italy in $89 \mathrm{BC}$.

96 Miller (2003: 82): in 2002 government ministers introduced 91.7\% of bills and $85.6 \%$ of those bills enacted were government ones.

97 See Sandberg (2001) for the argument that following Sulla's reforms curule magistrates were permitted to legislate via the tribal assembly. 
allowed on the tribunal, and posed the question (rogatio) to be answered by the vote. Anyone could attend these public deliberative meetings and all were free to defend or even oppose measures, although the usual participants held at least the rank of praetor. ${ }^{98}$ The reliability of speeches delivered in contiones has been questioned because these meetings were little more than political contests designed to win over supporters. ${ }^{99}$ This theory is too cynical. We could instead interpret the practice of addressing the people at contiones as an important democratic element as it was the only way at the time to publicise the debate, and discuss issues with the community of citizens. Certainly, it provided skilled orators such as Cicero the opportunity to compose some compelling speeches: witness the speech Cicero delivered at Rullus' contio on his agrarian bill in 63 BC. Indeed, Millar emphasises the role of the orator and persuasion. ${ }^{100}$ Cicero hints at the active role of the audience at contiones and implies that power lies in public meetings, even though it contravenes the tradition of the ancestors:

[Resolutions] are not based upon considered votes or affidavits nor safeguarded by an oath, but produced by a show of hands and the undisciplined shouting of an inflamed mob. Oh, if only we could

\footnotetext{
98 Nicolet (1980: 286-289). See Chapter Five below on the ex-centurion Sp. Ligustinus, who was invited by the consul and tribunes to talk about his military service (Livy 42.34).

99 Mouritsen (2001: 15).

100 Millar (1984: 18f; 1986; 1995a; 1998). See also Pina Polo (1996: 34 ff.) on non-magistrates addressing contiones.
} 
maintain the fine tradition and discipline that we have inherited from our ancestors! But somehow it is now slipping our of our hands. Those wisest and most upright of our men did not want power to lie in the public meetings [but in the assemblies]. (Flac. 15)

This depiction of what had become a typical contio, the show of hands in response to a question asked by the speaker, the shouting of answers and suggestions, ${ }^{101}$ shows the importance of such meetings as simultaneously an opportunity for magistrates to persuade the people and the people to express its will, for contrary to the theory that only those invited by the presiding magistrate were able to speak, it must be remembered that the populus Romanus could communicate its support or lack or it by way of this hand showing and shouting. They had redress to other forms of public demonstration too. ${ }^{102}$

The development of the secret ballot in the second century was another crucial democratic element. Without voting tablets (tabellae), voters' decisions were public knowledge. This lack of privacy compromised the citizen's liberty, his freedom to vote as he pleased, and compelled votes to follow the direction of influential men and patrons. Cicero states that the advent of the tabella was a "champion of liberty thanks to its secrecy" (vindex

\footnotetext{
101 As usual with Cicero's forensic speeches we need to take care with his often unfair interpretation of participants at public meetings. They are here characterised as the authors of undisciplined shouting, and termed an "inflamed mob". The evidence is from a defence speech designed to dirty the reputation of that "mob".

102 For more on demonstrations at contiones see Chapter Five below.
} 
tacitae libertatis, Leg. Agr. 2.4). Voters could no longer be called to account by their patrons who under the system of oral voting could stand near the pontes and oversee the vote of their clients (Plut. Aem. 31.7). The secret ballot was introduced first for elections in 139 BC by the tribune A. Gabinius. He successfully passed a bill through the concilium plebis (Cic. Leg. 3.35; Lael. 41; Livy Per. 54). ${ }^{103} 137$ BC saw the lex Cassia extend the secret ballot to all trials before the people (except those dealing with the charge of perduellio) thanks to the support of Scipio Aemilianus, who convinced the tribune M. Antius Briso to withdraw his veto (Cic. Brut. 97; 106; Leg. 3.35-37; Sest. 103; Lael. 41; Corn. 1, fr. 50 and Asc. 78 C; Schol. Bob. 135 (St)). ${ }^{104}$ The secret ballot was finally introduced into legislative assemblies in 131 and so made complete the replacement of the rogatores who went through the assembly asking individuals whether their vote was negative or positive regarding a bill or judgement. Following the reform, citizens scratched V (uti rogas) or A antiquo on their tabella cerata.

Another democratic element was the widespread participation of men from all orders in the tribal assembles. Anyone who qualified for citizenship was allowed to vote, and so take part in the decision-making process of legislation. There was no hierarchy of status groups within the citizen body

103 Nicolet (1980: 267ff.).

104 For the secret ballot see further Finley (1983: 112 f. with nn. 30 and 31) and Brunt (1971b: 66). 
as a whole: libertini voted alongside ingenui, but freedmen and newly enfranchised citizens were disadvantaged by being enrolled in only a limited number of tribes.

Historians have traditionally considered members of rural tribes to have had a more powerful vote in the legislative assembly. The 31 rural tribes contained citizens with property outside Rome, and the commonly held belief is that only those wealthy enough to have the time to make the trip to Rome could participate in legislation. The remaining four tribes were urban and held all other citizens, which meant these tribes contained more poor citizens than the rural ones. In addition, the freedmen were limited to these urban tribes for most of the Republic. The 35 tribes in which all Roman citizens were enrolled had equal weight as voting units, but contained unequal numbers voters. As a result citizens' votes were of unequal value. ${ }^{105}$

The four urban tribes were mainly made up of landless men, including freedmen, while the landed aristocracy preferred to be registered in the 31 rural tribes, even when their residence was in Rome. ${ }^{106}$ Some families, however, opted to remain registered in urban tribes in order to claim a link

\footnotetext{
105 Taylor (1960: ix.).

106 Taylor (1966: 64f.).
} 
to the original inhabitants of Rome and so augment their prestige. Thus we find an Aemilius Paullus registered in the Palatine tribe (ILS 949) and perhaps also a L. Manlius (ILS 4942). ${ }^{107}$ Rural tribes contained not only the landed aristocracy, but also the members of communities which had gained citizenship status over time. These citizens were predominantly, but not exclusively, peasant farmers; many diverse occupations were of course to be found in the towns outside Rome.

The majority of citizens resided outside the walls of Rome, and so, combined, ought to have had more influence in the tribal assembly. For this reason we might expect that legislation reflect more their interests than those of their city-dwelling cousins, especially since rural tribes outnumbered urban 31 to four. To fairly represent the proportion of citizens living in the city, the tribal assembly would have needed to provide nine urban tribes to balance 27 rural. ${ }^{108}$ But on the other hand, rural voters were disadvantaged as most would have been unable to afford the time to travel to Rome to participate in elections or, especially, the more frequent

107 Scullard (1973: 22 n.1).

108 On population numbers see Brunt (1966: 6 n. 9): during the last census in the late Republic 910,000 male citizens were recorded, and once some allowance is made for those who failed to register, Brunt estimates the total male citizens population to have been approximately 1,200,000, a quarter of whom lived in Rome based on the number of grain recipients in the 40s (Brunt 1966: 8 citing Suet. Caes. 41 cf. Dio 43.21.4). See also De Ligt (2007) and Scheidel (2008). 
legislative assemblies. Many citizens lived a long way from Rome, and after the Social War this number dramatically increased since all free male inhabitants of the Italian peninsula south of the Po were enfranchised. In theory, then, only those wealthy enough to have the leisure time and money to make the trip could participate. In practice, however, rural immigrants to Rome brought their rural registration with them, and so voted in rural tribes. This was especially the case in the late Republic, when the censors failed to perform their duties and revise tribal registrations between 70 and 23 BC. Consequently, there is evidence of urban residents voting in rural tribes. As early as 133 BC we see Ti. Gracchus, having lost his rural support at harvest time, looking to the support of the urban plebs in the tribal assembly (App. BC 1.14), which would have been pointless had their vote been limited to the four urban tribes. ${ }^{109}$ Indeed, Appian confirms that the first two tribes pronounced for Gracchus. Brunt notes that only a handful of immigrants who had removed to Rome between censuses may have been enough to outvote the small number of rural dwellers who attended the assembly. Based on Gracchus' decision to use the urban plebs in his attempt to secure re-election, plus the epigraphic evidence which also indicates the influence of urban dwellers in rural tribes, Brunt rightly concludes that it is

\footnotetext{
109 Brunt (1988: 25 f.). For the participation of rural voters in Gracchus' agrarian legislation in 133, see Appian (BC. 1.10). It should be noted that Tiberius would also have lost the support of those seasonal workers amongst the urban voters who worked the harvest. Brunt rightly points out that Cicero addresses rural tribesmen dwelling in the city in de Leg. agr. 2.71.
} 
probable that the plebs who lived in the city normally had a majority in the tribal assembly. ${ }^{110}$ Tatum likewise makes the claim that the urban plebs dominated most legislative assemblies, but refers to urban tribesmen rather than rural plebs who had moved to Rome but still voted in their rural tribes. ${ }^{111}$ Tatum cites Lintott, 112 who must be the source of this misunderstanding, based on a misreading of Cicero's seduction of the plebs urbana in his speech against Rullus' land reform bill (Leg. agr. 2.70f.) in which the orator is clearly appealing to those who enjoy the benefits of living in the city. For this reason, then, plebs urbana should be understood to mean plebs who are "urban dwellers," not the narrower definition "urban tribesmen." 113

Legislation and judicial decisions were predominantly made by those residing in Rome as voting on laws and judgements could occur at any time, but not preceding elections (which were held in July following Sulla's reforms) or on dies nefasti. Yet there had to be a lead time of at least 17 days

\footnotetext{
110 Brunt (1966: 7).

111 Tatum (2009: 5)

112 Lintott (1999b: 204)

113 See Purcell (1994: 644) for the definition: "the Roman citizens resident in the city who were not members of the senatorial or equestrian census-categories." Also OLD "urbanus" $1 \mathrm{~b}$ "living or pursuing one's activities in the city (usu. Rome)."
} 
(trinum nundinum) between the posting of a rogatio and the voting day.114 According to Rutilius (consul in $105 \mathrm{BC}$ ), this time lapse was in order to allow rural dwellers time to finish their work in the fields before coming to Rome to trade and legislate. ${ }^{115}$ The jury is still out on who benefited from such a lengthy time between promulgation of a bill and the vote upon it. Optimates might have benefited because the trinundinum meant that they had more than two weeks to prepare a response to rogatores sponsoring popular measures, but equally they may have been disadvantaged as the provision prevented them from proposing laws immediately after an election and so make use of any Italians still in town, those who were sufficiently wealthy to have made the journey to Rome for elections in the first place. These wealthier individuals from the towns and countryside of Italy were more likely to share the the views of, and so have voted with, the more conservative senators. ${ }^{116}$

\footnotetext{
114 Disagreement exists regarding the meaning of trinum nundinum (three market days). Cicero tells us that triunum nundinum must elapse between the promulgation of a law and the vote on it (Cic. Dom. 41). Taylor (1949: 207 n. 61) states that the lex Caecilia Didia of 98 required an announcement ante trinum nundinum for both proposals of laws and elections. Brunt (1988: 23) says three nundinae equal three weeks. See Lintott (1965) for the evidence and the convincing argument that the requirement was for promulgation of a bill on three market days, which means that the period between promulgation and vote had to be at least 17 days. Lintott (1999b: 44 with notes 20 and 21) also refers to the original practice of candidates presenting themselves before the people on three market days prior to election day, which evolved into the practice of canvassing for a trinundinum.
}

115 Millar (1998: 20) cites Rutilius via Macrobius Sat. 1.16.34 and acknowledges that other sources give other reasons for the nundinae, upon which he does not elaborate.

116 Taylor (1949: 207 n. 61). 
Brunt contends that the people never achieved the level of management of everyday affairs such as was achieved by the fifth century Athenian assembly because assembly meetings were rare in the late Republic. ${ }^{117}$ Yet he provides no evidence. Cicero gives the impression that assemblies met regularly to pass laws: "leges videmus saepe ferri multas" (Sest. 109). We must remember that there were more ways for a citizen to participate in legislation than by voting. Citizens who wished to participate in Roman political life found themselves with a part-time job as contiones and assemblies were summoned at least 20 times per year for a total of $40-60$ days. 118

The tribal distributions were far from fair. Although the tribes furthest from Rome tended to be the largest (Velina, Pollia), their tribesmen had more influential votes if they could afford the time and expense to make a trip to Rome come legislation time as the votes of the few who made this journey were accorded the same weight as those of the many who attended the tribal assembly from the older tribes closer to Rome. The smallest rural tribes (Romilia, Lemonia) were nearest Rome. These differences in size may have

\footnotetext{
117 Brunt (1988: 24).

118 Nicolet (1980: 237) bases this conclusion on the evidence of Macrobius: 'with the growth in numbers of the people the assemblies were well attended even in the period between two market-days' (Sat. 1.16).
} 
compensated for the limited ability of distant citizens to travel to Rome and attend meetings and assemblie. Fewer men made the journey from the more distant territories. Taylor believes such a "consideration of the number of voters who would come to the comitia was clearly a factor in the expansion of certain tribes, and particularly of these two [Velina and Pollia] which had been marked out for distant voters from the time of Gaius Flaminius."119 Yet, although this balanced the number of voters likely to attend, it was not fair on the citizen from the far off tribes as they had further to travel and therefore were not likely to make the journey.

Participation of citizens from rural tribes took two forms. As noted above, the wealthy could afford to come to the city to vote - whether they were tempted to depended undoubtedly on the issue. Others had migrated and were now resident in Rome (or lived close by the city) and had the time, for whatever reason, to participate. Distance did not, however, always put people off from making the trip to town to vote. Cicero describes the indignation of the homines honesti atque in suis vicinitatibus et municipiis gratiosi at a Manilian law which "confused the vote" of the centuries. This law enacted that votes were counted by tribes and the centuries ignored (Cic. Mur. 47). While this example relates to the centuriate assembly and

119 Taylor (1960: 99). 
elections, it nonetheless provides evidence of the rich making the short trip to Rome to vote. Another instance occurs in $70 \mathrm{BC}$, when a crowd (frequentia) from all Italy attended Rome for the elections, census and games (Cic. Verr. 1.54). Cicero also tells us that the local plebs from Atina fairly near Rome, who voted in Teretina tribe, turned up to vote for local boy made good Plancius when he stood for the aedileship (Planc. 21).

In order to participate in legislation, citizens really needed to reside in Rome or be able and willing to make the trip to Rome. Laws were passed in the Forum Romanum, and with plenty of notice thanks to the trinundinum. But the majority of citizens resident outside Rome did not attend legislative assemblies and there existed no opportunity or mechanism by which those absent could cast votes.

So let us look at who dwelled in Rome. The majority were very poor, a mixture of libertini and ingenui. Most of these appear to have been enrolled in urban tribes, but there is evidence that some of the poorer residents of Rome retained rural registration. Tiberius Gracchus' attempts to gain the support of these city dwellers suggest that there must have been rural tribesmen among the urban proletariat. ${ }^{120}$ There was also immigration to

120 See above and Brunt (1988: 26 n. 47). Sources for urban dwellers in rural tribes: App. 1.10, 14, 29 f., 32; Cic. de leg. agr. 2.71. 
Rome, although the number of immigrants and the period during which change of residence was significant is the subject of debate.

\section{IMMIGRATION TO ROME}

People moved in and out of Rome, but the strongest evidence for urban drift dates from after Clodius' frumentary law of 58 BC. For although Sallust records that impoverished rural plebs were attracted by the expansion of the dole during the 60s, Brunt queries Sallust's accuracy and suggests that as he was writing in the 30s Sallust may be reflecting more what was happening in his day, following Clodius' corn law of 58.121 The clincher is that it was not until 58 that corn was actually given away for free rather than merely subsidised. Although corn was first subsidised by C. Gracchus in 123 (Plut. C. Gracc. 5), even then the distributions were never constant but sometimes reduced, first by a Lex Octavia (Cic. Brut. 222; de off. 2.72). Saturninus seems to have re-enacted the Lex Sempronia (ad Her. 1.12.21). There is some confusion over whether Saturninus' laws were annulled (Diod. 36.16; Cic. de

\footnotetext{
${ }^{121}$ Brunt (1962: 69 f.). Sallust includes in the list of "scum" pouring into Rome "the young men who had eked out a wretched existence as agricultural labourers." He adds that "they had been tempted to the capital by the public and private doles which were lavishly handed out to the populace by candidates for office, and had come to prefer the comparative ease of city life to the thankless toil they had left" (Cat. 37.4-7).
} 
orat. 2.107; Balb. 48 ). Then came Drusus who in $91 \mathrm{BC}$ "with the assistance of the Italians carried by force laws on the distribution of land and corn" (Livy Per. 71), only to have them repealed with senatorial backing (Cic. de Leg. 2.14; Diod. 37.10.3). Sulla abolished subsidised grain completely (Sall. Hist. 1.55.11 M), but by 73 limited distributions once again existed (Cic. Verr. 2.3.163, 173 and 5.52; see further $M R R$ 2.109). Cato increased the recipients to around 200,000 in 62. It was not until Clodius' legislation during his tribunate in 58 that grain was given free to a large list of recipients. ${ }^{122}$

Corn alone was not enough to attract people to the capital. As Brunt notes, "the prospect of free grain encouraged further immigration from the country, but free grain alone did not sustain life" ${ }^{123}$ Dreams of prosperity were no doubt frustrated: while some might have got jobs on building projects, work for most would have been hard to find. Yet this has never stopped people from moving in the hope that the grass really will be greener on the other side.

There were other reasons to move to Rome. Although the evidence comes from men writing in the 40 s and $30 \mathrm{~s} \mathrm{BC}$, and other sources are imperial, we can tentatively suppose that these practices dated back into the Republic,

122 See Chapter Four below on the popular influence behind the grain laws.

${ }^{123}$ Brunt (1971b: 135). 
continuity being a theme in Roman culture. Varro ( $R R$ 2.3ff.) relates the migration of family heads to Rome. Appian (BC 2.120) claims that corn dole in 44 attracted the lazy, the beggars, the vagrants of all Italy to Rome. Livy (39.3.4-6) records that ambassadors from allied colonies and Latin cities came to Rome in 187 to complain that too many of their citizens had migrated to Rome, and as a result 12,000 were compelled to return to the place they had originally been registered. The problem recurred in 177 when the consul Claudius restricted Latin migration to Rome (Livy 41.9). Although Livy places migration of Italians to Rome early in the second century, we can believe it persisted: the historian is renowned for his anachronistic attribution of circumstances of his own time to earlier periods.

The residents of the communities surrounding Rome had a long history of migration to the city. Influential families from Etruria, Tusculum, and Campania made the move during the early days of the monarchy ${ }^{124}$ and the practice persisted during the Republic, though increasingly the move was made by soldiers who had lost their farms while they were away campaigning, or those dispossessed by creditors. Citizenship was the prize for non-citizen men who left their towns for the big smoke: those Latins who 124 Scullard (1973: 10). 
migrated to Roman territory could exchange Latin for Roman status. ${ }^{125}$ The attractions of the city tempted poor assidui (farmers) to move to Rome.126 Depopulation of the old ager Romanus was caused by wars and depopulation as poor peasant families emigrated to colonies and to Rome.127 Rural workers drifted to Rome to benefit from shelter and doles handed out by aristocrats, with employment provided by seasonal work in the countryside and jobs in construction or on the docks. ${ }^{128}$

Many men may have experienced a relatively high level of transience, moving to and from the city. ${ }^{129}$ This restless group was by no means homogenous: freedmen might have sought employment outside the city, failed farmers a second chance at Rome. Other groups, such as seasonal workers, were no doubt continually on the move. The usual practice saw the censors change a man's tribe when he changed his residence as part of the quinquennial census, but during the last generation of the Roman Republic the usual practice struggled to exert itself. No census was held

\footnotetext{
125 Brunt (1971a: 85).

126 See also Yakobson (1999: 147 and 229); Brunt (1988: 26 n. 47); Cic. Arch. 24; Sall. Hist. 27; Hor. Ep. 2.2.39; Livy 5.20.6; 42.20.4 (but cf. 7.25.8).

127 Brunt (1971a 345 ff.); Cornell (1995: 393 f.)

${ }^{128}$ Brunt (1971a: 380f.).

129 Purcell (1994).
} 
between 70 and 28.130 We cannot say for sure what happened to men who moved residence in this period when the census was enfeebled, but it is fair to suppose they retained their former registration in rural tribes. A man's original domus dictated tribal affiliation, so that when small farmers immigrated to Rome they retained their rural tribal affiliations, thus strengthening the vote of the poorer citizens in legislation. ${ }^{131}$

There is a school of thought that claims poorer Romans did not participate in politics because they were not interested in the issues being debated. ${ }^{132}$ Yet rogationes clearly did address issues of interest to the poor. The surviving statutes reveal the nature of the measures debated in the contiones and put to the legislative assembly. These addressed a number of social issues and so could be expected to appeal to the popular interest. But was this appeal enough to encourage participation by a broad section of society?

130 Brunt (1988: 25) disagrees with those (unnamed) historians who suggest that the tribal lists therefore became out of date.

131 Taylor (1960: 149); “The upper classes, senators, knights and tribuni aerarii, most of them landholders in Italy, were in all the rural tribes [despite the requirement that they keep a house in Rome].... As for the lower population, it included many of the small farmers who had once manned Rome's legions and who, having lost their farms, had been attracted to Rome by the grain dole. These men may have retained their registration in rural tribes, at least for the tribal assembly, though perhaps not in the classes of the centuriate assembly. For the votes on laws the comparatively small group of rural tribesmen in the city had great influence. But the great bulk of the lower population must have been in the four urban tribes." See also Taylor (1949 ch. 3) for the power of urban plebs come legislation time; for it was in this setting that popular leaders could best manipulate the plebs. According to Taylor, then, the plebs never in fact had power in its own right.

132 See for instance Mouritsen (2001). 
Attendance depended on leadership, political context (that is, the state of political affairs both at Rome and elsewhere) and the nature of the bill.133

So then, the evidence we have suggests that citizens from every order could vote with the confidence that their vote would count, although distance from Rome and lack of interest might have put some off. But those who did attend the tribal assembly would have found in their fellow tribesmen a varied bunch of both wealthy and poor men. Naturally enough, some issues failed to ignite the imagination and then turnouts were poor. Cicero reports one such tiny turnout: “We often see many laws passed. I say nothing about those which are passed under such conditions that scarcely five in each tribe, and those not from their own tribe, are found to vote" (Sest. 109). This has been interpreted to mean there was a dearth of rural voters, yet it more likely reflects a lack of interest.

\section{FREEDMEN}

Now that we have established that rural tribesmen were present at legislative assemblies in significant numbers because of migration to Rome, we need to move onto the presence of another element of the population:

133 Williamson (2005:133-144) analyses the range of issues, calculating that $20 \%$ of bills during the late Republic involved distribution of resources. 
men newly enfranchised, free and freedmen. These two groups experienced fluctuating voting power as they were enrolled in only a limited number of tribes. The freedmen suffered most by having their enrolment restricted to the four urban tribes, regardless of where they lived.

It is important to assess the influence of the vote of freedmen in the late Republic, for evidence suggests that those libertini who resided in Rome formed a large and active section of the plebs urbana. Cicero, for instance, gives the impression that the majority of Clodius' supporters were freedmen in order to imply that Clodius appealed to a "lesser" class of citizen (Att. 2.1.8; Dom. 53 f.; 89; Sest. 34). Numbers of freedmen may be exaggerated as Cicero often fails to distinguish freedmen from slaves (Mil. 87; Ascon. 52 C). ${ }^{134}$ Epigraphic evidence gives the impression that freedmen outnumbered ingenui in Rome three to one.135 Of course such a scanty

${ }^{134}$ Cicero's bias against the urban plebs comes through clearly via his rhetorical technique of terming freedmen slaves: "Why then, Lucullus, do you bring me into disfavour, and summon me before a public assembly, so to speak, and actually imitate seditious tribunes and order the shops (tabernas) to be shut? For what is the object of your complaint that we are abolishing the practical sciences, unless it aims at stirring up the craftsmen (opifices)? But if they all come together from every quarter, it will be easy to stir them on to attack your side! I shall first expound the unpopular doctrine that all the persons then standing in the assembly (in contione) are according to you exiles, slaves and madmen" (Acad.. 2.144). Asconius (52 C) corrects Cicero's negative portrayal of urban tribesmen: "At this time laws were being engraved at his house which would make us subject to our own slaves", stating that "among Clodius' proposed legislation there was one measure: this provided that freedmen who hitherto voted in only four tribes should be permitted to vote in the rural tribes also, these being the preserve of freemen".

135 For the ratio of 3:1 freedmen to free born in the tomb inscriptions of the late Republic see Taylor (1961: 118). She bases her conclusion on almost 200 republican inscriptions in CIL I, 2,1226-1422. 
sprinkling of fewer than two hundred tomb inscriptions is not representative of the population of Rome. There is an additional dilemma regarding the motives for leaving inscriptions: some hold that freedmen were more likely than freeborn to want to celebrate their life's achievements in stone. ${ }^{136}$ Nonetheless, in conjunction with the evidence of Cicero and others, there can be no doubt that freedmen resident in Rome formed a significant section of those who voted on laws in the Forum. In addition, many of the shops surrounding the Forum provided workspace for craftsmen who were often freedmen, thus placing them tantalizingly close to the action on voting days, provided, that is, they could get leave from their employers to attend. Those on piece rates would have been free to attend so long as their bosses could spare them.

The influence of the freedmen's vote waxed and waned during the Republic. For although freed slaves became Roman citizens, their vote was weakened when freedmen as an order were restricted to registration in urban tribes. Freedmen, however, were periodically enrolled in rural tribes, thus increasing their influence in both tribal and centuriate assemblies.

\footnotetext{
${ }^{136}$ Brunt (1962: 70 n. 15) disagrees with Taylor's suggestion that ingenui were less likely than freedmen to leave behind epigraphic evidence. Mouritsen (2005) has reasoned that the proliferation of freedmen's epitaphs deterred free men from setting up their own, with the result that freedmen are over-represented.
} 
Romans were relatively generous in their manumission of slaves. ${ }^{137}$ Although our sources' lack of objectivity demands caution of interpretation, we can nevertheless conclude that slaves were freed in numbers sufficient to cause concern over which tribes they were enrolled in. The usual practice was to register all freedmen in the four urban tribes, thus minimising the impact of the group's vote in both the tribal and centuriate assemblies in the late Republic. Urban registration occurred regardless of whether the libertini lived in Rome or outside Rome, regardless of whether he stayed in the countryside or in a town or migrated to Rome.

Both Dionysius of Halicarnassus and Appian comment on the practice of granting civitas to libertini. Appian notes cynically that the pure blood of Roman plebeians was diluted with that of freed foreigners, so that "freedmen have equal rights of citizenship with [plebeians]" (BC 2.120). His attitude is a reflection of the conservative elite during the late Republic. Dionysius is less critical of the practice when he reports that King Tullius

\footnotetext{
137 Wiedemann (1985: 162-175) suggests that manumission was less frequent than has been supposed by those who base their arguments on statistics gleaned from funerary inscriptions as these are more likely put up by descendants of freedmen keen to celebrate their freedom than those who fail to achieve manumisson. Also, he emphasises the master's self-interest as the prime reason for manumission: once freed, the ex-slave owed his master a debt of gratitude through which the master expected his slave to work for him, and the master no longer needed to house, feed and clothe the slave. A win-win situation from the master's point of view.
} 
innovated to enlarge the citizen body by admitting not only foreigners but even manumitted slaves:

For he ordered these also to report the value of their property at the same time as all the other free men, and he distributed them among the four city tribes, in which the body of freedmen, however numerous, continued to be ranked to my day; 138 and he permitted them to share in all the privileges which were open to the rest of the plebeians. (4.22)

Tullius, according to Dionysius, convinced the patricians to support his proposal by pointing out that the freedmen and their sons would be loyal clients to them and their descendants (4.23). Dionysius thus reflects the ever pragmatic Roman approach to enfranchisement.

Masters (domini) granted their slaves freedom as a reward for good work and loyalty, out of respect for the individual, as an incentive to other slaves to behave well in the absence of a police force, to prevent slaves testifying against masters under torture, to rid themselves of older slaves who had become a burden, or to make the newly enfranchised citizen eligible for the corn dole; the custom was that freedmen still owed ex-masters, now patrons, duty once manumitted.139 During the proscriptions, slaves might receive their freedom for killing a proscribed man. ${ }^{140}$

\footnotetext{
138 See below for periods during which, contrary to Dionysius' opinion, freedmen were assigned to all 35 tribes.

139 Treggiari (1969: 11-20). Several sources suggest that state subsidisation of corn caused a rush of manumissions because it offered an incentive to masters to manumit, and thus no
} 
Citizenship (civitas) was conferred at the same time as libertas, as Livy reports in his account of the first manumission: the slave who informed against the conspiracy to restore the Tarquins was rewarded with freedom and citizenship (2.5.9 f., libertas et civitas; see also Plut. Publ. 7). This Vindicius was the first freedman and so great was his service to the new Republic that he was allowed to choose the tribe to which he would belong. Cicero also acknowledges the link between freedom and citizenship:

You advance no reason why, if liberty cannot possibly be taken away, citizenship can. For we have inherited the same tradition with regard to both, and if once it is possible to take away citizenship it is impossible to preserve liberty. For how can a man enjoy his rights to the freedom of a Roman citizen if he is not among the number of Roman citizens? (Caec. 96). ${ }^{141}$

longer feed and house slaves yet still retain their service as once freed slaves still had to perform operae for their patron. Cassius Dio records that Pompey's grain distribution was delayed because "many slaves had been freed in anticipation of the event [and so] he wished to take a census of them in order that the grain might be supplied to them with some order and system." (39.24). Dionysius of Halicarnassus claims that in the good old days most slaves were freed due to worthy conduct while a few purchased their freedom, which was nonetheless lawful and honest. But the situation had so deteriorated by his day (i.e. during Augustus' Principate) that robbers, burglars, and prostitutes were able to buy their freedom, or worse still men who had aided and abetted poisoners and murderers, traitors and blasphemers. At the end of this list of unworthy freedmen he adds those who received the corn dole in order to pass it on to their former masters (Dion. 4.24); Treggiari (1969: 27 f.).

140 During the Second Triumvirate a slave was rewarded with his freedom and so granted citizenship if he killed a proscribed man (App. BC 4.11), although in reality death was sometimes the slave's reward for betraying his proscribed master (App. BC. 4. 29).

141 It should be noted, however, that Cicero proceeds to enumerate upon two instances whereby a free man (liber) might lost his liberty (viz. evasion of military service and refusal to be included in the census). He excuses his double standard on the grounds that the former were never free in the first place and the latter repudiated their freedom (Caec. 99). 
Cicero also emphasises the connection between libertas and civitas in his attack on Clodius for having him exiled without trial (Dom. 77).

Freedmen were added to tribal rolls in one of three ways, depending on the method of manumission. Those freed by a magistrate (vindicta) were perhaps enrolled by the same magistrate in one of the four urban tribes, while those freed censu were enrolled then and there by the censors. Slaves freed by will (testamento) would have waited to be enrolled in the next census. $^{142}$

Libertini thus enjoyed the basic rights of citizenship, although these were limited in several ways. Not only was their vote weaker as a result of registration in only four out of 35 tribes during most of the Republic, but they struggled to gain access to the equestrian order and so political office. Freedmen also suffered reduced rights of succession, litigation and marriage. ${ }^{143}$ In addition, no matter what their legal status, freedmen always suffered socially for having once been slaves. Evidence of their social slur associated with servile background is ubiquitous in the written sources. ${ }^{144}$

\footnotetext{
142 Treggiari (1969: 41).

143 Treggiari (1969).

144 See, for example, Appian (BC 2.120) on freed foreigners diluting the blood of plebeians, quoted above.
} 
Freedmen were teased with the prospect of registration in rural tribes. From time to time magistrates sought to have libertini enrolled in all 35 tribes. Magistrates, usually censors and tribunes of the plebs, tried to elevate the status of freedmen from second class citizens several times in the last three centuries of the republic. Otherwise freedmen possessed little clout in the tribal assembly due to their large numbers being crammed into the four urban tribes, even if they resided in a district where free-born citizens belonged to a rural tribe.

Appius Claudius Caecus was the first magistrate who sought to redistribute freedmen through all the tribes, rather than have them limited to membership of the four urban tribes alone. During his censorship in 312 Claudius first tried to open the Senate to the sons of freedmen by putting their names on the senatorial roll (Diod. Sic. 20.36.3; Auct. Vir. Ill. 34), ${ }^{145}$ but the consuls of 311 refused to use the new list of senators. ${ }^{146}$

145 Cf. Suetonius (Claud. 24.1) who quibbles that in Appius' day libertini referred not to freedmen themselves but to their freeborn sons and it was these, the grandsons of the freedmen, who gained entrance to the senate under Appius. Treggiari (1969: 53) rightly notes that Suetonius' idea gains no support from any other source, all of whom support the emperor Claudius' argument that he was following his ancestor's example by adlecting sons of freedmen to the senate (Tac. Ann. 11.24; Plut. Pomp. 13; Diod. Sic. 20.36; Livy 9.46.1).

${ }^{146}$ Livy states that the consuls of 311 ignored Claudius' new list of senators (and I quote at length to include highlight the disdainful tone with which the reform was greeted by not only the consuls but Livy's source): "the consuls of the following year... complained to the people at the outset of their administration that the senatorial order had been depraved by the improper choice of members, in which better men had been passed over than some that had been appointed. They then gave notice that they should ignore that list, which had 
Despite this temporary setback, Claudius forged ahead with another piece of legislation. The censor used his powers to redistribute men from overcrowded urban tribes into the tribes of their patrons. ${ }^{147}$ Livy records a slightly different version of the reform, substituting humiles for freedmen:

Claudius had been the first to debase the senate by the appointment of the sons of freedmen, and afterwards, when no one allowed the validity of his selection, and he had failed to gain the influence in the senate-house which had been his object, he had distributed the humble denizens (humiles) of the city amongst all the tribes, and had thus corrupted the Forum and the Campus Martius. (Livy 9.46.11)

There has been some debate over to whom "humiles" refers. Badian agrees with Taylor that the term must refer mostly to freedmen, including those resident in the country based on the rationale that Appius would surely have courted such an important group. ${ }^{148}$ Treggiari believes that "humiles" refers to freedmen based on Livy's inclusion of the topic in his treatment of Claudius' failed attempt to get freedmen into the senate. Plutarch indeed reinforces her claim when he records in his section on the first ever freedmen that 'as for other freedmen, Appius, wanting to make himself popular, procured them a right of voting' (Publ. 7). Diodorus Siculus

been drawn up with no distinction of right and wrong, in a spirit of favouritism and caprice; and proceeded to call the roll of the senate in the order which had been in use before Appius Claudius and Gaius Plautius were censors" (9.30 $1 \mathrm{f}$.).

147 Treggiari (1969: 41 f.) states that these were mostly libertini as many city ingenui had been sent off to colonies.

148 Badian (1962: 206 f.); Taylor (1960: 137). 
(20.36.4) claims that Claudius "also gave each citizen the right to be enrolled in whatever tribe he wished and to be placed in the census class he preferred," but this sounds rather too generous. Treggiari is no doubt correct to suggest that freedmen were included in their patrons' tribes. ${ }^{149}$ Claudius' reform remained in force until it was overturned in 304, which suggests that the freedmen had some power before this point to resist challenges, or else that Claudius' opponents were powerless. The censors in 307 followed his example but those in $304^{150}$ reacted to the election of $\mathrm{Cn}$. Flavius, son of a freedman and himself a scribe, to the curule aedileship by reversing Claudius' law and reassigning all freedmen and their sons to the four urban tribes (Livy 9.46.10, 14). ${ }^{151}$

At least one other pair of censors followed Claudius' example, but we do not know when. There may of course have been more, but the sources for this period are lean and made more so with the loss of Livy's books covering the period from 291-222 BC.152 Livy's second decade has not

\footnotetext{
${ }^{149}$ As she notes, this was the technique later favoured by Manlius (1969: 42).

150 The censors were elected irregulary in this instance, hence the three year gap.

$151 \mathrm{Cn}$. Flavius was elected curule aedile "to the vast indignation of the nobilitates" (Val. Max. 2.5.2 - note that Val. Max. mistakenly states elsewhere that he reached the praetorship, 9.3.3)). The unknown author of Vir.Ill. records that Q. Fabius Rullus "removed the sons of freedmen from the list of tribes" (32). See also Plutarch (Pomp. 13) who records that Fabius Rullus was given the title Maximus when as censor in 304 he expelled freedmen's descendents from the senate after they had been enrolled due to their wealth.
} 
survived, so we have only other fragmentary sources covering the period 292-219. In addition, all books after book 45 (which takes us to the end of 167 BC) are lost. But two kinds of summary have survived: the Oxyrynchus Epitome, which covers books 37-40 and 48-55 and was composed during first half of third century, and Periochae ('Summaries') composed in the fourth century AD of all 142 books except 136 and 137 . The summary of book 20 tells us that "freedmen were assigned to four tribes, whereas before they had been dispersed through them all" (Livy Per. 20). ${ }^{153}$ This reform should perhaps be attributed to the 220 s as it is contained in the Periocha of book 20, although the reliability of the Periochae is such that no firm statement of date can be made.

Efforts may also have been made by Scipio the elder in 189/188 to win new supporters when he backed the tribune Terentius Culleo, who persuaded the tribes to carry a law which compelled the censors T. Quinctius Flamininus and M. Claudius Marcellus to register all men of free birth in tribes including the sons of freedmen and to disperse them among all the

\footnotetext{
152 Livy does, however, refer to events and personalities from his missing books in later books, so all is not lost: historians are able to piece together enough evidence to gain some picture of the period.

153 Treggiari (1969: 42) agrees with Taylor's suggestion (1960: 138) that Q. Fabius Maximus returned freedmen to the four urban tribes.
} 
tribes (Plut. Flam. 18.1). ${ }^{154}$ Treggiari disagrees with Taylor's suggestion that freedmen's sons were the target of this lex, and suggests instead that it applied to illegitimate sons of ingenui for Plutarch mentions only freeborn residents and does not specify that their fathers were freedmen. ${ }^{155}$ Similarly Badian points out that the single source is very vague and mentions neither freedmen nor tribes, so that the only conclusion that can be reached is that Culleo, with the support of the populace, forced the censors to add to the roll of citizens all freeborn men. ${ }^{156}$ Indeed, the evidence of Plutarch is insufficient to support Taylor's theory that the sons of freedmen were the exclusive target of the legislation. Instead we should consider the possibility that all hitherto unregistered freeborn men were the object of the lex, including both illegitimate sons of ingenui and sons of libertini.

There is also considerable debate over the form of the change in voting that occurred in 179 , which perhaps limited freedmen once more to urban tribal registration. Our only source is Livy and he records that the censors of 179 $\mathrm{BC}$ "changed the method of voting and constituted the tribes according to

\footnotetext{
154 Taylor (1960: 138 f., 306 ff.); Bleicken 1955: 68 ff. Interestingly, this same Culleo as praetor peregrinus in 187 ejected 12,000 Latin allies from Rome (Livy 39.3.4-6). No doubt he was acting in the interests of the Italian communities who were suffering a loss of man power to Rome. Indeed, ten years later C. Claudius Pulcher as consul proposed a law adapting the ius migrandi so that men who moved to Rome only gained citizenship if they left a son behind (Livy 41.9.9-12).

155 Treggiari (1969: 43).

156 Badian (1962: 207).
} 
districts and to the social origins (generibus) and status (causisque) and income (quaestibus) of the members" (40.51.9). Walsh comments on the lack of detail supplied by Livy and notes the obscurity of what detail he does supply. He suggests that the reference to social origins is meant to distinguish those of free birth from those who were once slaves, with the result that a freedman with a son and property valued at 30,000 sesterces or more was now eligible to vote in the appropriate tribe (which can be assumed from the reform referred to in Livy (45.15.1 ff.), for which see below); that "status" probably means that of the family, that is whether the family has male progeny and therefore eligible for enrolment in a rural tribe (as above); and "income" determined allocation of class, so that those with over 30,000 sesterces belonged to the first or second class and so not only were they able to seek registration in a rural tribe, but they also voted first. 157 Badian remarks that "Livy clearly cannot have had any idea of what these men did: his words cannot have made sense even to himself", and instead recommends that we use this passage as evidence for the existence of "a pair of unusually efficient censors early in the second century."158 The emphasis on redistribution according to region is revealing: it indicates that the small farmers who had moved to Rome after losing their farms while

\footnotetext{
157 Walsh (1996: 173)

158 Badian (1962: 204 f.)
} 
absent fulfilling their military duties had greater influence than was usual. The reform of 179 was trying to redistribute these men to lessen their power.

There is evidence that during the second century an increasing number of freedmen took up residence in rural areas, some of whom came into possession of sizeable estates. Taylor and Staveley take Livy (40.51.9) to mean that freedmen who possessed landed property sufficient to gain them access to the second class and with sons older than 5 years were permitted to enrol in rural tribes, which they believe is supported by this concession's removal ten years later (Livy 45.15.1-2). ${ }^{159}$ Taylor suggests that the focus of reform was on these men who lived in country district as the change in registration of 179 was regionatim, that is by district, and so unlikely to affect residents of Rome. But later it was the freedmen resident in the city of Rome that became the object of reformers because their votes would have been valuable in legislation, thus the efforts to get them registered in all tribes. 160

159 Taylor (1960: 139 f.) and Staveley (1972: 140 f.). Note that Staveley errs in his end notes when he cites as the source Livy 41.50 .8 instead of 40.51.9.

160 Taylor (1960: 147). Also (158): "if [the city freedmen] could be distributed, as their patrons were, through all the tribes, [they] would have had great influence on the votes on laws which were usually in the hands of the city population." But compare Treggiari (1969: 164f.) who rightly suggests that Taylor $(1949: 54)$ is wrong to claim that patricians at first sought to manipulate freedmen in rural tribes, and only later (after the Lex Tabellaris of 139 BC) did populares try to woo them with gifts of favourable rural registration. 
Two further instances of reshuffling registration methods occurred during the second century BC. The first saw libertini once more transferred from rural tribes to one single urban tribe by the censors of 169-168 B.C., C. Claudius Pulcher and Ti. Sempronius Gracchus. Livy records the decision of the censors:

Freedmen had been distributed among the four city tribes except for those who had a son over five years old (these they ordered to be reckoned where they had been enrolled at the census immediately previous), and those who had an estate or estates in the country valued at over thirty thousand sesterces [censors' or tribes' names] ${ }^{161}$ the privilege of enrolling was granted. Although the arrangement had become established in this way, Claudius said that it was impossible for a censor without a decree of the people to deprive any individual of his ballot, let alone a whole class. For if, said Claudius, the censor could move a man from his tribe, which was exactly what ordering him to change his tribe meant, he could remove him from all thirty-five tribes, that is, deprive him of citizenship and status as a free man - not determine where he should be enrolled but exclude him from enrolment. This was argued between the two censors; finally they resorted to the following solution: they drew lots publicly in the Hall of Liberty for one of the four city tribes, to which they would consign all those who had been slaves. The lot of the Esquiline tribe was cast; Tiberius Gracchus announced that they had decided to enrol all freedmen in this tribe (Livy 45.15.1-6)

- one of the many reforms made by the two who became known for the severity of their measures. ${ }^{162}$ Cicero is surely mistaken when he says that Gracchus "libertinos in urbanas tribus transtulit" (De Or. 1.38). That Gracchus and Claudius reduced freedmen to registration in one tribe should

\footnotetext{
${ }^{161}$ At this point there is a lacuna in which the Loeb editor believes the rural tribes for these wealthy freedmen may have been listed; cf. Badian (1962: 207) who suggests the hiatus would have contained the names of the censors responsible for the change.
}

162 Treggiari (1969: 34, 47). 
not surprise anyone. To reiterate: these censors were notorious for their "tristis ...atque aspera censura" (Livy 43.16.1), for their tough treatment of those whom they regarded as unworthy, regardless of whether their victims were freeborn or once slaves: they deprived many equites of their horses (Livy 43.16.1, 44.16.8) and were so mean when they let contracts that the tribune of the plebs Rutillius charged them with perduellio (Livy 43.16.2-16; Val. Max. 6.5.3).

There was more activity in 115, when the consul M. Aemilius Scaurus carried a law affecting liberti, but only the bare details are recorded: "Consul legem de sumptibus et libertinorum suffragiis tulit" (Auct. Vir. Ill. 72.5). Sulpicius Rufus next sought to distribute freedmen more fairly throughout the tribes as tribune in 88 (Asc. $64 \mathrm{C}$ ). He proposed that those exiled by Sulla should be recalled, that new citizens and freedmen should be distributed among the tribes, and that Gaius Marius should be appointed commander to oppose Mithridates (Livy Per. 77) but had his legislation annulled by Sulla (App. BC 1.59), only for it to be revived under Cinna, although only two sources specifically refer to libertini (Schol. Gron. 286 Stangl and Livy Per. 84; cf. on new citizens: Cic. Phil. 8.7; Vell. 2.20.2; App. BC 1.64). The law was abolished once and for all by Sulla as dictator in $81 .{ }^{163}$

163 Treggiari (1969: 37-52); Taylor (1960: ch. 10). 
Manilius also tried his hand at improving the weight of the freedmen's vote during his tribunate in 66 by spreading them throughout the tribes only to have his legislation annulled the following day for failing to observe the trinundinae. ${ }^{164}$ There is some disagreement over the reason behind the annulment of the law. Treggiari backs the argument that it was termed invalid because it was carried by force (following Dio 36.42.2), whereas Taylor says it failed because Manilius did not observe the lead time of trinundinae. 165 Whatever the reason the result was the same: freedmen were not registered in all 35 tribes.

Finally, Clodius was planning a reallocation of tribes for freedmen when he died in 52, but again there is disagreement between secondary sources. Treggiari suggests he aimed to "enrol freedmen in the same tribes as their patrons, since Cicero complained that people like himself would have been controlled, which probably means outvoted by their own freedmen."166 Clodius' promise to enrol freedmen who lived outside the city in the rural

\footnotetext{
164 Asconius (45C) contradicts himself, at first stating that Manilius proposed a bill "ut libertinis in omnibus tribubus suffragium esset" then changing the bill so that it pertained to the franchise of the sons of freedmen, on the details of which Asconius (64-65 C) is vague. Dio says Manilius "had granted the class of freedmen the right to vote with those who had freed them; this he did on the very last day of the year toward evening, after suborning some of the populace" (36.42.2).

165 Treggiari (1969: 50); Taylor (1960: 144 f.).

166 Treggiari (1969: 50). Cic. Mil. 87; Asc. 52C.
} 
tribes was perhaps a deliberate ploy to win votes in the centuriate assembly in his effort to attain the praetorship. ${ }^{167}$ Clodius' carrot makes sense if freedmen had some influence in the centuriate assembly and so would increase the likelihood of his successful candidature, otherwise his purpose in buttering them up is unclear. ${ }^{168}$ The freedmen's vote in the comitia centuriata was limited to only 8 of the 70 first class centuries (see below), so it is unlikely that Clodius expected their support to ensure his election. Rather he hoped to impress the patrons of these men who, following redistribution, might have increased numbers of clients in the more influential rural tribes. ${ }^{169}$ The method of redistribution varied: some reformers sought registration according to location of domus, others would have freedmen enrolled in the tribes of their erstwhile masters.

Sons of freedmen were in a better position vis-à-vis voting clout as they could probably secure registration in rural tribes if they owned property in

167 Evidence for Clodius planning legal reform that would see Cicero and his ilk 'made subject to their own slaves' (Cic., Mil 87); Asconius expands upon these mysterious words of Cicero: the law proposed that 'libertini, qui non plus quam in IIII tribubus suffragium ferebant, possent in rusticis quoque tribubus, quae propriae ingenuorum sunt' (Asc. 52 (C)); a Clodian programme (leges Clodianes) found in Clodius' house (Mil. 89); that Clodius planned to redistribute freedmen "Nec suffragia dabis, quibus ostentas....Nec vero illam nefariam libertatem" (De aere alieno Milonis, frr. 17, 18 (Crawford)); Schol. Bob. 173 (St).

168 Unless Clodius was following family practice. Tatum (1999: 237) suggests a traditional Claudian tactic was to take an interest in freedmen's electoral rights.

169 Thus Taylor $(1960: 133,146)$ : those who tried to redistribute freedmen through the rural tribes sought a new client class. 
the countryside. ${ }^{170}$ It has also been suggested that the elite would have tried to secure the registration of their freedmen in the rural tribes. ${ }^{171}$

170 Treggiari (1969: 52) is rather speculative here, offering neither sources of evidence for this claim nor examples.

171 Scullard (1973: 22). Disappointingly he supplies no sources to reinforce his verdict. But his suggestion is sensible. 


\section{NEW FREEBORN CITIZENS}

Freedmen were not the only citizens to suffer restricted tribal registration; those freeborn Italians who gained citizenship following the passage of the lex Iulia also experienced unequal tribal distribution. The Italians who were enfranchised following the Social War were freeborn, yet they were at first enrolled in ten newly created tribes in 90BC:

The Romans did not enrol the new citizens in the thirty five existing tribes, lest they should outvote the old ones in the elections, but incorporated them in ten new tribes, which voted last. So it often happened that their vote was useless, since a majority was obtained from the thirty five tribes that voted first. This fact was either not noticed by the Italians at the time or they were satisfied with what they had gained, but it was observed later and became the source of a new conflict. (App. $B C 1.49)$

But these new tribes were abandoned after the new citizens demanded distribution throughout all rural tribes with the help of Cinna and others. For they were unhappy with the prospect of second class citizenship, as the new tribes were huge and would vote after the existing 35 tribes, thus rendering their vote unnecessary if a majority had already been reached. Velleius Paterculus criticises Cinna's lack of restraint and in so doing emphasises the senator's role in this struggle: 
Accordingly, although the citizenship had been given to Italy with the proviso that the new citizens should be enrolled in but eight tribes, ${ }^{172}$ so that their power and numbers might not weaken the prestige of the older citizens, and that the beneficiaries might not have greater power than the benefactors, Cinna now promised to distribute them throughout all the tribes. (Vell. Pat. 20.2)

Appian attributes the strife to the actions of Marius and the tribune of the plebs Publius Sulpicius in 88 BC, for Marius planned to use the new citizens to further his own ends once their vote was strengthened via tribal redistribution. The old citizens, however, were not prepared to have their vote weakened and fought the new citizens "with sticks and stones" so that the consuls were compelled to proclaim a cessation from all public business to put off the voting and attendant violence (App. BC. 1.55). The main problem with Appian here is that he does not define who the "old citizens" were - which sector of Roman society was prepared to risk life and limb to participate in this action against the new citizens in the forum? Sulpicius was not put off by the consuls' proclamation and after forcing them to flee the city, his laws were enacted, one providing for tribal reallocation and another giving Marius command against Mithridates (App. BC. 1.56). But Sulla had his laws annulled after he marched on Rome (BC. 1.59). Sulpicius met his end in the aftermath (App. BC. 1.60). Following Sulla's departure for

172 The discrepancy regarding the number of tribes created for the newly enfranchised Italians is discussed by Taylor (1960: 102f. n. 6 ). Sisenna records that the new citizens were enrolled in two tribes (fr. 17 Peter). 
the East, Marius retook Rome and all the new citizens were eventually enrolled in all 31 rural tribes (App. BC. 73). ${ }^{173}$

Newer citizens' voting clout was diminished because they were registered in the bigger tribes. Factional politics played its part. The distribution of new citizens in tribes following the Social War favoured Marians:

Great inequalities remained in the tribes, with the largest tribes in general at a distance from Rome. The distributions were carried out in the interests of the Marian-Cinnan party, and perhaps some sign of their influence can be detected, for instance in the wide distribution of tribes in Etruria, a region favorable to Marius, and in the influential position accorded Sora in the Romilia, a site on the border of Marius' home, Arpinum. ${ }^{174}$

Sulla later settled veterans in Etruria in an attempt to increase his support in a hitherto Marian district.

There exists further evidence of senatorial influence over tribal allocation of new citizens. Following the enfranchisement of the Transpadani these new citizens were distributed over at least twenty of the 31 rural tribes, thus providing these northern Italians with influence in the majority of tribes. Taylor believes the spread was designed "to serve Pompey's influence against the Sullan nobility". In the end, however, the distribution served 173 Taylor (1960: 101-107); Gabba (1994: 123-128).

174 Taylor $(1960: 117 ; 314)$. See Ch 16 for tribes of senators. For the general character of the tribal assignments see $115 \mathrm{f}$. 
Caesar's interests against those of Pompey for Caesar was able to use his influence as governor of Cisalpine Gaul to encourage these men to enlist (Caes. BC. 3.87.4) - helped by the fact that Caesar ultimately secured full citizenship rights for them in 49.175 Hirtius records that Caesar sent his lieutenant Sergius Galba to stand for the consulship and M. Antonius for a priesthood and regularly asked voters to travel to Rome for elections ( $B G$ $8.50)$.

Treggiari suggests the new citizens with the best chance of gaining access to rural registration were the individual provincials like Balbus, who moved from one of the urban tribes to the prestigious Clustumina (Cic. Balb. 57), of which Pompey was a member (ILS 8888). ${ }^{176}$ Influential freedmen may have enjoyed the same sort of privileged treatment. Magistrates could also confer privileges. The case of Seleucus, a newly enfranchised nauarchos (captain of

175 Brunt (1962: 77); Taylor (1960: 130 f.). Brunt (1971b: 142) suggests that even the erstwhile Pompeian supporters from Picenum went over to Caesar because Pompey could not protect them, despite his father's granting them Latin rights in 89BC, whereas Caesar as proconsul had long recruited his legionaries from among their number and granted them full enfranchisement in 49 BC. They respected his authority; Caesar was their patron.

176 Treggiari (1969: 52) refers to Taylor $(1949: 54,114)$ and notes that while technically the reward was for a successful prosecution, the transferral to a more influential tribe reeks of favouritism. But such a change of registration to the tribe of the convicted man was the standard practice according to Roman criminal law (Taylor (1960: $18 \mathrm{f}$ )); Lex repet. (CIL $1^{2}$ 583)). 
a vessel), provides one such example, for Octavian had him registered in the rural tribe Cornelia in gratitude for services rendered. ${ }^{177}$

Elite manipulation of tribal affiliation was a challenge to the fair sharing of voting clout and so the democratic nature of tribal voting. The composition of tribes was tweaked by senators hoping to increase their own personal power and auctoritas. Senatorial influence over voting districts was achieved during the creation of districts and new tribal assignments. There were several methods of achieving this influence. In the days when new tribes were still being established, the big gentes left their old ones to take up land and influence further from Rome, thus doubling their influence as they still held sway in their original tribes (which were named after them). ${ }^{178}$ They saw to it that newly enfranchised clients were registered in their own tribes, thus increasing their influence amongst their tribesmen. ${ }^{179}$ They weakened the influence of other tribes by making them huge and keeping their own small, thus weakening the strength of the individual vote, and increasing their own relatively. ${ }^{180}$ Ultimately, the desire to enrol clients in

\footnotetext{
177 On Seleucus see Ehrenberg and Jones (1949: 301).

178 Taylor (1960: 299).

179 Taylor (1960: 305 ff.; 311).

180 Taylor (1960: 303 ff.; 308 f.).
} 
one's own tribe contradicted the desire to have fewer voters and so a weightier vote. ${ }^{181}$

Romans were aware that unfair tribal distributions diluted the power of legislative votes. This much is clear when we see the efforts of those who tried to make the distribution more fair, especially for newly enfranchised free and freedmen, with mixed results. That the struggle existed to do away with the unequal distribution illustrates that we are dealing with an emerging democracy, where there was awareness of what was right, and the beginnings of change for the better.

\section{VOTING AREAS}

The limited capacity of voting areas has been used in arguments against the existence of democracy in Rome. The areas were too small to contain every single eligible voter, whether it be the Campus Martius where the centuriate assembly was convened, or the gathering area of the tribal assembly in the Forum. 182 The existence of two distinct voting areas can in part be put down to the tradition which barred soldiers from crossing the pomerium. The other

\footnotetext{
181 Taylor (1960: 314 f.).

182 See Mouritsen (2001: Chapter 2) for the latest and most conservative estimates; Taylor (1966); MacMullen (1980: 454-7); Richardson (1992) for layout of public spaces.
} 
reason is the different voting procedures. ${ }^{183}$ Thus elections could not be held in the Forum where there was not enough space for all 193 centuries to assemble at once. Legislative and judicial assemblies on the Capitoline outside the temple of Jupiter Optimus Maximus were limited by the small area, but only from 211-121 BC, after which Castor's tribunal became available. Legislative assemblies were held outside the temple of Castor. Pontes carried voters up stairs to vote at the tribunal. ${ }^{184}$

Theories abound regarding the capacity of the Forum and Saepta. The majority share the view that the areas in which assemblies gathered to vote were too small to contain all those citizens eligible to vote. ${ }^{185}$ While it is impossible to establish the exact number of citizens eligible to vote in the assemblies, it is clear that the areas in which the people met to vote were insufficient to hold every citizen. This small size of congregation points can be taken as evidence for the levels of voter participation: not every citizen was expected to turn up. As stated elsewhere, soldiers and farmers busy with the harvest could not make the trip to Rome. Others refrained from

\footnotetext{
183 Taylor (1966: 40).

184 Taylor (1966: 43 f.).

185 There are some, however, who do not deal with the issue. For example, Mouritsen (2001: 16) criticises Millar for being vague regarding the basic components of politics, "the scale and capacity of the popular institutions... numbers, composition, motivation and behavioural patterns."
} 
voting for various reasons, such as lack of interest in the issue to be legislated upon and general apathy. But although only a small minority attended meetings and assemblies in the Forum, any level of popular participation is remarkable at a time when the average citizen endured long working days (if he was lucky enough to have work that is), food shortages, and other worries about survival.

Taylor bases her opinon that the ordinary citizen did not exercise his right to vote on the evidence of the setting of assemblies. There is no way everyone who was qualified to vote could physically cast a vote due to insufficient space in the Forum and even the relatively capacious Saepta would have held only 70,000 men, which may have been room enough for the centuriate assembly (as many citizens had no property and so little clout), but not the tribal.186 In addition, there is evidence of voters being excluded and shouting their support for candidates from nearby rooftops (Plut. G. Gracchus 3.1). ${ }^{187}$ Taylor suspects that these spaces did not need to fit the whole citizen population of the city as those of the four urban tribes had such a weak vote, even though they were the majority of the inhabitants, that they would not bother voting. ${ }^{188}$ Contrary to what Taylor suggests,

\footnotetext{
186 Taylor (1966: 52 ff.) calculates numbers of voters and who could vote in reality.

187 cf. Mouritsen (2001).

188 Taylor (1966: 113).
} 
however, the Saepta would have held roughly one third of the male citizens resident in Rome. If these many men participated, then that would be a higher rate than that expected by the existence of the 6,000 man quorum at the Athenian ekklesia.

It is clear, then, that the system for voting was not designed to include every potential voter. We need to ask why, when reformers worked to make unfair aspects such as tribal distribution more egalitarian, there were no moves to make full participation possible. The answer may well be that Romans considered the existing system satisfactory because it did cater for those who did arrive at assembly areas to vote. Only on the rare occasion was pressure put on the capacity of voting areas (as above). The areas were, quite simply, big enough.

\section{ELECTIONS}

The space allocated to elections was substantial, especially after the reform of the Saepta. It was here that the citizens decided who from among the senatorial and equestrian order would hold office, that is, who would take command of armies, preside over courts, and manage the administration of 
Rome, Italy and the provinces. The populus Romanus decided who would effect policy in these areas too, as only magistrates could propose laws. The citizens elected these magistrates, so the electoral procedure will be examind in this section to examine whether some citizens had more influence than others in the election of magistrates.

Again it is the people who bestow office on the deserving, the noblest reward of virtue in a state; the people have the power of approving or rejecting laws, and what is most important of all, they deliberate on the question of war and peace. Further in the case of alliances, terms of peace, and treaties, it is the people who ratify all these or the reverse. Thus here again once might plausibly say that the people's share in the government is the greatest, and that the constitution is a democratic one. (Poly. 6.14.912)

Policy-making was thus theoretically in the hands of the people as magistrates were elected by popular vote, laws were passed in popular assembly and foreign policy (or at least the decision to go to war) was made by the people. The tribal assembly began to break with tradition and so set new precedents in the late third century $B C$ in that it elected military commanders, recalled military commanders, and ended wars. ${ }^{189}$ But as a rule the senate and centuriate assembly ruled over external (that is, military) affairs, while the tribal assembly decided domestic matters. As wars

\footnotetext{
189 Sandberg (2001: 137) cites instances of the populus electing commanders, mostly during the Hannibalic War (Livy 29.13.7 (204 BC), 30.27.3-4 (202), 30.41.4 (201), 35.20 .9 (192); Cic. Phil. 11.18 (131). See Rotondi (76-77) for a list of leges and rogationes enacted which recalled commanders. Tribunicians passed laws ending wars according to Livy $(30.40 .14,30.43 .2-3$, 33.25.6-7) and Polybius (18.25).
} 
became less attractive (for a number of reasons: less booty, grimmer conditions of service, especially in Spain) citizens' reluctance to enlist further influenced foreign policy. 190

The Roman constitution in the late Republic has been criticised for the lack of direct popular involvement in the development of policy at Rome: it has been compared to classical Athenian democracy and found wanting in that fewer citizens, it is supposed (bearing in mind the inexact nature of our evidence of numbers participating), presented themselves at voting time. Yet we know that wars were the result of a vote of the people, and so the people played a significant role in the direction of foreign policy. Other examples include increasingly frequent interference in the realm of foreign policy in the late Republic, beginning with Ti. Gracchus' gaining popular support for his annexation of Pergamum.

It has been suggested that the senate had more control over setting policy than the people. Those citizens outside the senate had no direct influence on military policy except through the comitia centuriata, but even then evidence suggests that the question was not always put to the vote from the second

\footnotetext{
190 Toynbee (ii. 95 f.) notes that peasants became reluctant during the second century to sign up because following the Hannibalic War the aim was no longer to protect Rome but "the maintenance and extension of an empire."
} 
century. ${ }^{191}$ In the later Republic, however, the senate found its powers increasingly wrested from it, and it tended to be offended when foreign policy decisions were made by other bodies. Livy (21.63.3 and 38.36.8) as noted above records that the enfranchisement of men from Formiae, Fundi and Arpinum went ahead without senatorial authority in 188 BC. Again, the people took the initiative and made the decision to support the generals, a faction of the senate, in their plan to relieve Messana against the votes of the majority of senators, and so began the First Punic War (Poly. 1.11.1-3). In 167 B.C. the praetor peregrinus $\mathrm{M}^{\prime}$. Iuventius Thalna tried to start a war with Rhodes without senatorial sanction but was prevented by tribunician veto (Livy 45.21.1-8). Diodorus says the praetor appealed to the people for support; he summoned the assembly and urged the people to make war on Rhodes (Diod. 31.5.3). Thus Thalna provided the precedent for Tiberius Gracchus, who gave the power to decide foreign policy to the tribal assembly in the case of Attalus III's bequest in 133. In this case, Tiberius

\footnotetext{
191 See Harris (1985: 263) for wars lacking the authorisation of a comitial vote, including against the Galatians in 187 with neither the authority of senate nor people (Livy 38.45.4-7, $46.13,48.9,50.1$ ), the Istrian war in 178 (Livy 41.7.8, though since the aggressor was the brother of the man who attacked the Galatians Livy or his source may be developing a topos rather than reporting what actually happened), the Third Punic War (App. Lib. $75 \mathrm{f}$.), the Jugurthine War, and Mithridatic War (App. Mith. 22.83; Livy 4.30.15; cf. Cic. Pis. 50). Compare Sandberg (2001: 138 with n. 25) who, as noted above, suggests that the tribes declared war.
} 
Gracchus was acting in the public interest; he "asserted the sovereign right of the people to take decisions without prior sanction of the senate."192

Examination of the procedure surrounding election of magistrates reveals both democratic and undemocratic elements. Voters were given plenty of time to decide whether they wanted to take part in elections, depending on whether any men worth supporting were standing for office. A candidate made his preliminary notification (professio) at least seventeen days (trinundinae) before the day on which the elections were to be held. If his professio was accepted by the presiding magistrate, the candidate began campaigning or canvassing (petitio). Informal meetings (contiones) called by friendly magistrates to discuss public business provided an opportunity for candidates to present their agendas and criticise their opponents. ${ }^{193}$

The electorate was subject to continual canvassing as candidates competed for annual elections, some beginning well in advance (Cic. Att. 1.1). By the late Republic some began their election campaigns a year before the big day, utilising the tribal organisation with its divisores (election agents), men who distributed candidates' hand-outs to their tribules (fellow tribesmen), originally to their own tribes for the purpose of securing the tribe's vote, but

192 Brunt (1988: 32).

193 Mouritsen (2001: ch. 3). 
increasingly the process became perverted as candidates bribed other tribes to vote for them (ambitus). ${ }^{194}$

Favourable auspices were needed before an assembly could be called, a prerequisite open to abuse in the ultra-competitive days of the late Republic. ${ }^{195}$ Then after sacrifice and prayer came a preliminary contio probably limited before elections to statement of business with little or no discussion (in contrast to the deliberative function of the contio preceding acts of legislation and jurisdiction). Non-voters withdrew after the contio and the voters divided into centuries or tribes separated by ropes or wooden fences in an enclosure (ovile or Saepta). Group-voting prevailed, but first individuals filed along narrow passages (pontes) to register their votes, originally verbally, with tellers (rogatores), although, following the reform of 139, voting was performed by secret ballot whereby citizens scratched the initials of the preferred candidate on tabellae ceratae (the lex Gabinia: Cic. Leg. 3.35; Lael. 41). These individual votes were tallied up and the vote of the majority determined the vote of the century or tribe.

In $241 \mathrm{BC}$ or shortly after, the comitia centuriata was reformed, so that there were 193 centuries divided into five classes. The evidence is patchy, but it 194 Bribery is discussed below. 195 See Chapter Five on methods of obstruction. 
appears that the first class contained 70 centuries, with each of the 35 tribes represented by two centuries, one each of iuniores and seniores, plus 18 centuries of Equites. Centuries voted one after the other, with the eighteen centuries of Equites originally voting first - these were the centuriae praerogativae. The order of voting was significant, as the remainder of the centuries often followed the lead of the first to vote (Cic. Planc. 49; Ad. Q. 2.14.4; Div. 1.103; Festus, 249.7). As election was decided once a majority had voted for a candidate, he was elected, even though he might not have received as many votes as someone who failed to be elected. ${ }^{196}$ Hence the additional importance of the lot choosing who voted first. At the time of the reform of the assembly the vote became more democratic "by no longer observing the strict ancient manner of calling [the centuries]" (Dion. Hal. 4.21.3), for now a century was selected by lot to vote first (the centuria praerogativa) and, while this was always from the first class, the new organisation was now based on tribe and so many small farmers were registered in each century, thus reducing the influence of the senatorial order. ${ }^{197}$ Following the publication of the vote of the praerogativa the remaining 69 centuries of the first class voted, with the result of each

\footnotetext{
196 Taylor (1966: 81 f.).

197 Taylor (1966: 91). Though Taylor (1960:303 f.) argues that any seeming democratisation of the process was illusory: the wealthy land owners still dominated the first class and were few, and so their vote had more weight. Scullard (1973: 20) supposes that this change occurred at the same time as the reform of the comitia.
} 
century proclaimed after each voted. Then came the turn of the 18 equestrian centuries: first the 12 centuries of equites, then the weird anomaly of the century of fabrii (engineers or craftsmen) followed by the six ancient equestrian centuries (sex suffragia): Tities, Ramnes, and Luceres. The second through fifth classes voted next. These constituted 100 centuries of uncertain distribution through the classes. Finally, the five unarmed centuries voted. Last to vote was the century of proletarii, a substantial percentage of the population, if not the majority (Dion. Hal. 4.18.2; 7.59.6). Cicero reports that the first class was but a small fraction of the citizen body (Rep. 2.40).

In addition, while voting ceased once a majority was reached in favour of one candidate, it was repeated for no office was held by one man alone. ${ }^{198}$ Ultimately, the centuriate assembly was still weighted in favour of elite, although now the majority was not reached until at least second class voted, which would have occurred fairly frequently as the competition between candidates was fierce in the late Republic, thus making a majority difficult to achieve for the aristocracy did not vote in one block. ${ }^{199}$ The success of the candidates was not confirmed until the presiding magistrate made a formal

\footnotetext{
198 Scullard (1973 19 n. 2) notes the problems in deciphering the reform; re. praerogativa: Scullard 1973: 20 n. 1 with Livy 43.16.14 and Cic Phil 2.82.

199 Taylor (1966: 88 ff.); Scullard (1973: 21)
} 
announcement of the result (renuntiatio). Very occasionally a presiding magistrate refused to confirm the election, as occurred in 67 when Piso disagreed with the result (Val. Max. 3.8.3).

More of a challenge to the emerging democracy of Rome than the arbitrary actions of consuls such as Piso was bribery. Wealthy men owed a duty of euergetism: they were expected to "feed their own tribe". As a display of civic benefaction, patrons were expected to give clients gifts, or impress their own tribe with public games or buildings. It was traditional and legal to give gifts of money in order to win elections. ${ }^{200}$ Yet exceeding the legal limitations saw men charged with ambitus or bribery. In this sense, Romans had a concept of "corruption," as seen in the scathing comments in the Commentariolum Petitionis regarding bribery (56). People should instead support candidates because of past good work and prospect of more to follow (19). Also, by Cicero's day divisores had become professional bribery agents. Cicero had a concept of corruption, though no doubt it was different to ours. ${ }^{201}$ Veyne argues that Hellenistic euergetism in the form of "benefactor politicians" was a sign of a weakening democracy as

\footnotetext{
200 Tatum (1999: 57).

201 On electoral corruption see Gruen (1974: 212 ff.; 271 ff.); Nicolet (297 ff.); Lintott (1990); Yakobson (1992); corrupt divisores: Asc. 75 (C); negative view of divisores Att. 1.16.2, 1.18.4 (personal slur); Verr. 3.161; Planc. 48; De Orat. 2.257. Less negative: Verr. 1.22f.
} 
dependence on the wealthy few increased. ${ }^{202}$ Yet Rome was a different story from Athens as the Roman empire was expanding and needed investment on infrastructure - building programmes were the obvious result. If Rome resembled a period in Athens, it was more like that of the Peisistratid tyranny, than Periclean democracy, with similarly impressive public works and reforms for the common good. A similar phenomenon is visible in the contemporary New Zealand practice of dangling carrots in election year budgets and policy announcements regarding perennial vote winners such as tax cuts, restrictions on immigration, and abolition of interest on student loans.

Laws had long been in place to curb malpractice in elections (ambitus). The earliest was passed in $358 \mathrm{BC}$ to stop the campaigning of plebeian candidates who were making visits to market-places and to settlements of Roman citizens (conciliabula). ${ }^{203}$ Bribery was common in the late Republic and well organised through middlemen called divisores who arranged payments, originally to members of a candidate's own tribe. By the late Republic, however, the process had been perverted so that it no longer functioned as a legitimate form of patronage. Candidates, compelled to give gratuities to tribes other than their own in order to compete with the bribery

202 Veyne (1990).

203 Mouritsen (2001: 35) notes the law was probably aimed at novi homines. 
of the other candidates, employed another tier of agents, usually a friend or ally termed sequester or interpres, to ferry the funds to the divisor, for a candidate faced a certain charge of ambitus if he was caught directly handing funds intended for another's tribe to a divisor. ${ }^{204}$ It has been suggested, however, that moral probity was a pretext, and that the ambitus laws were really aimed at controlling electoral competition arising from personal ambition and the survival instinct. ${ }^{205}$

Bribery encouraged participation and was an institution in and of itself. Although the primary purpose of tribal headquarters, centrally located in Rome, was to organise voters, this function expanded over time to include the distribution of a cash incentive. Tribes managed the "bribery" themselves. Taylor describes the imperial procedure:

Through [the headquarters] men circulated (circumire tribus) to beg the members of the tribes for their votes. The officials of the tribes at this time were the curatores tribuum, elected in the empire and presumably in the republic by each tribe. There were other officers who had an important part in delivering the tribal vote, the divisores, whose duty was originally to distribute the gifts which it was legitimate for the wealthy members of the tribes to make to their fellow tribules. In the late republic, when bribery was rampant, these divisores, gave out money provided by candidates for all the tribes. Efforts to curb such donations by more and more severe laws on ambitus were ineffective, and bribery of the masses

204 See Linderski (1985) for more on the role of divisores.

205 Linderski (1985: 93 f.). 
lured to Rome by the emoluments of the ballot became a regular feature of the campaigns. 206

Bribery, then, can be added to food distribution and games as a lure to Rome. As we turn to the issue of participation in elections, we need to keep in mind the effect of such enticements on the composition of the citizen body that was present and voted at elections.

The degree to which the centuriate assembly favoured the vote of the tiny minority of extremely wealthy elite is currently under debate. Cicero emphasises its plutocratic bias (Rep. 2.39). While the centuriate assembly might appear to favour those in the first class because this small group of citizens was spread over more than its fair share of centuries, the popular element was more important than usually supposed.207 Yakobson notes the sheer size of the urban plebs, and concludes that it must have been "diverse enough in its social composition to provide the centuries of the first class with a good many voters" ${ }^{208}$ He also points out that when our sources mention the presence of soldiers in Rome at elections, this equates to the

\footnotetext{
206 Taylor (1960: 14 f.) cites: Festus (508 L) as evidence for tribesmen coming to Rome for comitia when rural tribes were all in close proximity to Rome; Livy (7.1.2-3) on the law preventing plebeians campaigning; and Taylor (1949: Chapter 3) on the use of tribal headquarters to gather votes by candidates and rogatores. See also Tatum (1999: 26 f.) on divisores with a note providing primary sources on aristocratic scorn of the post.

207 Yakobson (1999: 11, 233).

208 Yakobson (1999: 61).
} 
presence of rural tribesmen, for soldiers were recruited from among peasants not urban proletariat. 209

Although this might have been affected by the migration to Rome of farmers who had hit hard times, for veterans were amongst this number, it also resulted in the presence at elections of rural tribesmen. Hugh Last has argued that rural tribesmen had a marked influence on elections: poverty forced migration to Rome so that these additional rural tribesmen would not only be present dwelling in Rome, but were also mixing with the urban tribes in day-to-day life. This contact with urban poor meant the rural tribesmen adopted their urban cousins' interests, but on most occasions retained their registration in the rural tribes to which they belonged before moving their residence to Rome..$^{210}$ These men, if in need of money and unethical enough, would be more ready to sell their votes to men in tribes other than their own. ${ }^{211}$ It was, as we have seen, only a small step from the traditional practice of distribution amongst a candidate's own tribe to the more widespread largesse visible in the last generation of the Republic.

\footnotetext{
209 Yakobson (1999: 94).

210 Last (1932: 7-9).

211 Yakobson (1999: 147).
} 
The author of the Commentariolum Petitionis emphasises the importance of the popular vote at elections: he is scornful of Antonius because he preferred to go overseas and plunder the innkeepers, rather than stay in Italy and solicit the votes of the people (populo Romano supplicare, Comment. Pet. 8). He also reminds candidates of the value of rural tribesmen: the consular candidate should visualise the whole of Italy divided into its tribal divisions, and ensure he has sufficient support in every town, colony, and rural district, "or indeed any place in Italy". In order to achieve this widespread support the candidate is to "inquire and seek out men everywhere, get to know them, pursue them, secure them, see that they canvass their localities for you and act like candidates on your behalf" (Comment. Pet. 30f.). Cicero also notes their importance when he expects rural voters from Cisalpine Gaul to count heavily in the voting (videtur in suffragiis multum posse Gallia, Att. 1.1.2). Non-elite city dwellers were worth courting too: "reckon up the whole city - all the collegia, pagi, vicinitates; if you strike a friendship with the leading men from among their number, you will easily, through them, secure the masses that remain" (Comment. Pet. 30).

Political theorists hold that frequent elections are a prerequisite of democracy as elections offer the people the chance to oust an under- 
performing or unrepresentative government. ${ }^{212}$ The shorter the tenure, the more pressure on the government to keep the electorate happy. In this sense, the Roman system of annual elections during the Republic was relatively democratic: Roman magistrates were under significant pressure to perform according to the desires of those who elected them. Elections were held regularly and so allowed citizens ample time to schedule them in: they took place in July each year and would be well attended, more so than the tribal assemblies gathered for legislation which could be summoned at any time so long as the period of trinundinae had been observed. These were more likely attended by those at hand, and so tended to be less representative of the wider citizen body. By the end of the Republic, however, elections became irregular due to disprution, and so came more to resemble legislative assemblies in this respect.

The old theory that those whose wealth derived from property enjoyed more power because their vote dominated the comitia centuriata assumes they were united, which was clearly not the case in the late Republic, as competition to maintain dignitas resulted in fragmentation of friendships. ${ }^{213}$ Also, the centuriate assembly favoured the propertied citizens and

\footnotetext{
212 Henderson and Bellamy (2002: 75): in New Zealand "triennial elections provide for decisive periodic accountability."

${ }^{213}$ For fighting for dignitas consider Caesar and his decision to cross the Rubicon, as argued by Gruen (1974: 496 f.)
} 
especially the older voters (seniores, who were relatively few, yet were represented in half the first and second class centuries). While these could be expected to be conservative, they did not always act conservatively in the election of consuls: Marius, Cinna and Caesar were all consuls that clashed with the conservative senators. Yakobson offers an explanation: he notes how the votes of the lower orders shaped the outcome of elections and the preceding campaigns. He maintains that the competition at elections was such that the lower classes sometimes voted. The comitia centuriata did sometimes require every century's vote to decide an election, though not in Cicero's case (Leg. agr. 2.4).214

In praetorian elections especially, there were sufficient candidates to allow most centuries to vote, hence the encouragement in the Commentariolum Petitionis (53) to ensure the support of each stratum of society. ${ }^{215}$ Even if they did not always vote, ordinary Romans had to be courted for candidates had to gain wide support as they never knew who would turn up to vote form year to year. Yakobson's argument has not found favour in all quarters, however, as he has faced criticism for ignoring the evidence that the last century was almost never called on to vote (Dion. Hal. 4.20.5; Livy

\footnotetext{
214 Lintott (1999: 204 n. 41)

215 Yakobson (1999); Tatum (2009: 10).
} 
1.43.11). ${ }^{216}$ Yet the tiny amount of evidence we have fails to support either argument, so we should follow Tatum's suggestion that numbers varied. ${ }^{217}$

Freedmen wealthy enough to belong to the more powerful classes of the urban centuries may have had more clout in elections. On the whole, however, their impact in the centuriate assembly was similarly small to that of the tribal assembly because tribal membership and property classification combined to dictate the century to which each citizen belonged. Thus wealthy freedmen were limited to participation in 8 of the 70 elite (and most influential) centuries. That there were freedmen wealthy enough to have a vote worth courting is clear from the Commentariolum Petitionis (29): Cicero ought to include among his supporters the "multi homines urbani industrii, multi libertini in foro gratiosi navique." Lack of evidence has compelled some to speculate about the position of freedmen in the comitia centuriata, leading to the conclusion that "there is no evidence that freedmen were not registered in the appropriate classes." 218 The state could benefit from the collection of taxes from the richer freedmen (until citizens were relieved of this responsibility in $167 \mathrm{BC}$ ) and freedmen could vote in elections. The

\footnotetext{
${ }^{216}$ For few voters see Mouritsen (2001: 32 ff.), Brunt (1971a).

217 Tatum (1999: 29 ff.).

218 Brunt (1988: 171 n. 95).
} 
Commentariolum Petitionis agains provides the evidence for freedmen's influence in the centuriate assembly: if a consular candidate needed the support of freedmen who were "gratiosi navique in foro" (obliging and energetic in the forum, 29) then some libertini must have belonged to influential first and second class city centuries. ${ }^{219}$

As a result of the changing circumstances in the late Republic, the wealthy no longer dominated either the tribal or centuriate assembly. With increasing numbers of farmers and veterans moving to Rome, and slaves winning their freedom and so gaining citizenship, the balance was tipped in the favour of the non-elite voter. Therefore, each class of the populus Romanus could participate in Roman politics, and members of each did.

So much for the workings of the traditional assemblies. The following three chapters of case studies will examine the evidence for political participation outside the formal avenues analysed in the present chapter.

\footnotetext{
219 Treggiari (1969: 51). Freedmen may have been confined to one century, that of the capite censi, in an earlier period, but after the state enacted the reform above it stood to gain significant funds from libertini enrolled in the appropriate classes. In n. 4 Treggiari refers to A. Rosenberg's suggestion that the reform of the centuriate assembly in the third century sought to restrict the power of rich freedmen.
} 


\section{CHAPTER 3: DEMONSTRATIONS AND COLLECTIVE ACTION I: SECESSION, REFUSAL OF THE DRAFT AND MUTINY}

Few now deny the central role popular pressure played in decision-making during the late Republic: "Democracy did not exist in Rome, but popular pressure did."220 Citizens especially played a pivotal role, and so too did women and non-citizens, although the fragmentary and biased nature of the ancient sources prevents us from getting a clear picture of their significance. The citizens' ability to persuade the decision-makers that their opinion counted was then, as it is now, one of the most important aspects of popular sovereignty - even more so once we consider the popular assembly's central role in the decision-making process. In Rome, the senate was the central governing body, responsible for decisions regarding foreign affairs and redistribution of state finances; in addition it provided advice to magistrates. But senators did not govern alone; they shared power with the people at both the formal and informal levels. Formally, the people voted bills into law and elected magistrates, and informally various popular groups made their opinion known through demonstrations. They could also interfere in the areas considered the preserve of senators. If citizens wanted their

220 Yavetz (1969: 39). 
material interests attended to and their libertas preserved, they needed to persuade the senate to introduce bills which ensured that the wealthiest Romans shared the benefits of empire with poorer Romans. This meant not only redistribution of wealth and land won through conquest, but also the reasonable treatment of fellow citizens by those with imperium so that libertas was not compromised. We may well discover that a different sort of democracy existed in Rome.

In this chapter I will examine first how Roman citizens used the pressure of collective action to effect change in their favour via secessions, refusal of the draft and mutiny. I will use these case studies as a spring board into an introductory analysis of the nature of popular demonstrations and the identity of participants, both at leadership level and below. This analysis continues in the following chapters.

In Chapter Four, I will move onto other forms of demonstration, through which they sought material assistance in the form of subsidised and guaranteed grain distributions, land redistribution and debt relief, along with the restoration of tribunicia potestas. In Chapter Five, I will investigate how different elements within the populus used games (chariot races and theatre performances), contiones, triumphs, funerals, elections, legislative assemblies and trials to express their opinion and achieve their aims. There 
was a development, unreported by Livy, our main source for the early and middle Republic, from the use of military secessions and mutinies, to movements based more on urban elements of the population, although still with support from veterans and people from the countryside, towns and municipia.

The Roman people wielded power over the senate by the latent threat of secession. That is, the threat of withdrawing their military support and their productivity, for as not only soldiers but farmers and artisans also their contribution was significant. $^{221}$ There were no secessions in the late Republic, but the danger nonetheless remained despite changes to the practice of recruitment.222 And, of course, mutiny was common wherever there was a strong sense of unity and an understanding of common interests frustrated.223 The five secessions recorded by our primary sources in 494, $449,445,342$ and 287 succeeded in a relatively peaceful manner in preserving libertas and strengthening plebeian rights when these were threatened by members of the Senate. The plebeians showed impressive

${ }^{221}$ For food shortage following the first secessio plebis, see Livy 2.34.1.

222 The changes attributed to Marius meant members of the capite censi could be recruited should the assidui refuse, but this was far from ideal given their inexperience in comparison to veterans.

223 See Messer (1920) for the argument that mutiny was a common occurrence in the Roman army, the result of a tradition of freedom of thinking and acting. 
levels of organisation, their main method being collective bargaining reinforced by general strike. ${ }^{224}$ Out and out civil war was avoided, although only narrowly and not without violent episodes, as we shall see.

Such dark and desperate times were not easily forgotten; on the contrary, authors during the late Republic and early Empire recalled in sombre tones the discordia between the orders that caused the withdrawal of plebeian arms. They had themselves witnessed the disastrous effect of factional strife and refusal to compromise. And it is exactly such late Republican contamination that we need to scrape off early developments to avoid distortion of the historical reality. ${ }^{225}$ No doubt we will get a different idea of the situation than Livy, filtering as he did his reading of the sources through the experiences and understanding of a man living in the days following the Battle of Actium, when Octavian was shaping his new Republic. As for the argument that the secessions did not occur, ${ }^{226}$ while this has an impact upon our interpretation of the period and the development of key institutions of

\footnotetext{
224 See Canetti (1973: 63-66) on such "prohibition crowds."

225 See G. Forsythe (2005) and his review (BMCR 97.3.26) of T. J., Cornell, The Beginnings of Rome, London, 1995 and T. J. Cornell's review (CR 29.1 (1979): 106-109) of R. M. Ogilvie, Early Rome and the Etruscans, London, 1976. These two book reviews highlight the dangers of not taking authorial bias into account when tackling the unreliable material on the fifth century BC (e.g. the taint from contemporary laws and customs, and the likelihood of historians' access to the Annales Maximi even before they were published in the time of the Gracchi).

${ }^{226}$ Forsythe (2005: 172ff.); cf. Cornell (1995: 256-8, 263, 265-7, 273, 276,).
} 
the Roman state, it does not detract from the fact that the threat of secession, and indeed the threat of other forms of disharmony between the orders, loomed large in the minds of those living in the late Republic and early Empire. Take for example the gloomy omens that accompanied disagreement over the first agrarian law recorded in Livy:

Bellum inde Veiens initum, et Volsci rebellarunt; sed ad bella externa prope supererant uires, abutebanturque iis inter semet ipsos certando. Accessere ad aegras iam omnium mentes prodigia caelestia, prope cotidianas in urbe agrisque ostentantia minas; motique ita numinis causam nullam aliam uates canebant publice priuatimque nunc extis, nunc per aues consulti, quam haud rite sacra fieri; qui terrores tamen eo euasere ut Oppia uirgo Vestalis damnata incesti poenas dederit. (2.42.911)

The secessions were also used to threaten senators who opposed those seeking reform. Here, Sallust has Macer remind the Quirites in 76 how their ancestors used secession to secure tribunes as the defenders of their rights. Macer's speech aimed to rouse the plebs to take back their liberty which was then oppressed by the domination of the Sullan faction.

$\mathrm{Si}$, Quirites, parum existumaretis quid inter ius a maioribus relictum uobis et hoc a Sulla paratum seruitium interesset, multis mihi disserundum fuit, docendique quas ob iniurias et quotiens a patribus armata plebes secessisset utique uindices parauisset omnis iuris sui tribunos plebis. Nunc hortari modo relicuom est et ire primum uia qua capessundam arbitror libertatem. Neque me praeterit quantas opes nobilitatis solus, inpotens, inani specie magistratus, pellere dominatione incipiam, quantoque tutius factio noxiorum agat quam soli innocentes. Sed praeter spem bonam ex uobis, quae metum uicit, statui certaminis aduorsa pro libertate potiora esse forti uiro quam omnino non certauisse. (Sall. Hist. 3.48.1-4M) 
The use of historical exempla to persuade an audience occurs elsewhere also. There is evidence of a symbolic secession in the late Republic: Fulvius led some of C. Gracchus' supporters to the Aventine (Plut. C. Gracc. 15; App. BC 1.26; Livy 3.54, Per. 61), site of the second secession, which suggests that these Gracchans may have been trying to remind their fellow citizens of the dangers to the res publica of such disharmony as they were experiencing. The incident also prompted men to recall the origin of Gracchus' tribunicia potestas and the citizens' rights.227 Cicero similarly threatens the need for another secession to remind the prosecution in Murena's trial that members of plebeian families now counted as well born, thanks to the efforts of their seceding ancestors (Cic. Pro Mur. 15).

Analysis of the techniques used to encourage reform in the secessions sheds light on those used in the late Republic as our major source is Livy and we have already noted how his work is influenced by the era in which he lived. The first secession was in response to patrician refusal to address the debt crisis or, more precisely, refusal to stop abusing plebeians. 228 Plebeians used

\footnotetext{
${ }^{227}$ Chrissanthos (2004: 346).

228 Cornell (1995: 267). Cornell thinks that the "distinguished veteran" is a commonplace, perhaps modelled on a prototype from the fourth century after the institution of tributum at the end of the fifth, anachronistically mentioned in this story from 494 BC. That the figure is based on such a recognisable stereotype lends force to the argument for his existence.
} 
public oratory to recruit support, then the threat of their numbers, noisy disturbances, violence, refusal to enlist and, finally, secession to influence senatorial opinion. Veterans as high up the hierarchy as centurions had become debt slaves due to the twin dangers of defending Rome from marauding invaders and Roman creditors. ${ }^{229}$ An unnamed ex-centurion addressed the people in the Forum and so inspired other debtors, all veterans according to Livy, to demonstrate their frustration at the punitive debt laws. They surrounded the senate house, Livy explains, "to oversee and regulate the deliberations of the senate" (Livy 2.23). When the Volsci threatened to attack, the plebeians held the patricians to ransom and in a prelude to the first secessio plebis they said they would leave the patricians to fight the war against the Volsci unless the debt law was revised (Livy 2.24).

Was there even a debt crisis? Scholars have expressed the view that the problem of debt was created to explain the origin of the secession, since the issue does not appear again for some time after the first secession. The other possibility is that the record for the period is defective. The most sensible answer to the problem has been suggested by Cornell, who, after weighing up these two options, favours the defective evidence theory: there must have been a debt crisis as the conditions for one existed and the prominence

229 See below also for the centurion freed by Manlius Capitolinus (Livy, 6.14.3-8), who specifically placed the blame for his state of penury on usury, as interest piled up on his loan during his absence from home while fighting and then rebuilding his house (6.14.7). 
of the issue in the Twelve Tables confirms the persistence of the problem. ${ }^{230}$ Our sources' failure to preserve the record of an issue does not preclude the existence of that issue.

The popular reaction to the debt crisis forced the senate to act. Such a united instance of collective action could not be combated by force, so senators sought a peaceful resolution. The senate appeased the debtors, who enlisted immediately, by persuading the consul Servilius, "whose temperament was more in tune with popular feeling" than his colleague's, to pass an edict, which he issued to the people assembled in an informal contio. The edict stated that: "no Roman could be held in chains or prevented from participating in the levy, nor any soldier have his property sold or his descendents interfered with" (Livy 2.24.6). But his fellow consul Appius Claudius continued to pass harsh judgements on debtors (Livy 2.27.1). Servilius was powerless to help the people because all the nobles supported Appius. So, with no prospect of help from the consuls or senate, the plebs took action and obstructed the consul's judgments by making an uproar. They also resorted to violence, beating up creditors (Livy 2.27.8-9), equestrians, patricians and lictors (Dion. Hal. 6.34). In these ways Roman

230 Cornell (1995: 267) asks why debt drops off the radar after the first secession and posits these two possibilities. 
citizens outside the senate made their displeasure at magisterial intransigence known.

The power struggle between populus and magistrates continued when the new consuls took office in $494 \mathrm{BC}$. The plebs began to gather nightly on the Aventine and Esquiline hills, worried that these consuls too would ignore their plea for debt reform. Members of the plebs then refused to respond to the consuls when the latter tried to conduct the levy, insisting the senate adhere to its promise from the previous year to outlaw enslavement of citizens due to debt (Livy 2.27-28). They returned to fight the invading Aequi, Sabines and Volscians after the senate appointed a dictator, Manius Valerius, who resolved the stalemate with the promise of an end to debt bondage; he passed an edict based on the one issued by the consul Servilius the year before (Livy 2.28-30; Dion. Hal. 6.39-42.1). In the end the senate reneged on its deal, so Valerius resigned (Livy 2.31; Dion. Hal. 6.44) and the plebs withdrew to the mons Sacer under the leadership of Sicinius, who convinced them to secede rather than kill the consuls. Menenius Agrippa, himself a member of the plebs, convinced them to return to the city using the parable of body parts working together; for the disaffection of the plebs caused the civic body to waste away, just as the body wasted away when limbs and internal organs refused to cooperate (Livy 2.32; Dion. Hal. 6.8386). In this way harmony was restored and a new magistracy created to 
protect citizens from unfair treatment by curule magistrates: two (or five) tribuni plebis were given ius auxilii (the right to aid citizens in distress). In addition the lex sacrata was carried, making the tribunes inviolable: anyone harming a tribune faced the death penalty (Livy 2.33; Dion. Hal. 6.87-90).

Some have doubted the existence of this first secession, yet we must verify its existence to justify our argument that secession was a means of effective popular demonstration. The reasons for rejecting the event include the appearance of the tribunate as a fully formed office when it most likely developed over time, retrojection of powers dating from the time of the Gracchi, conflation of people, etymological connections interpreted literally (for instance, the plebeians' withdrawal to mons Sacer is derived from the lex sacrata), and topoi lifted from Greek history. ${ }^{231}$ Yet this hesitation seems exaggerated: the tribunate as described by Livy is created with only two powers: the proactive right to intervene on behalf of plebeians (ius auxilii) and its defensive status as magistratus sacrosanctus (2.33.1) - hardly the full arsenal the office later came to possess. ${ }^{232}$ There is also criticism of the rationale in Livy's story, claiming it is illogical to explain the creation of

231 Forsythe (2005: 171-176). Gabba (1991: 85) likewise notes that Dionysius of Halicarnassus projected certain topics of historiography from the first century B.C. back to the fifth, such as the debt problem.

${ }^{232}$ Cornell (1995: 259 f.) agrees: he traces, for example, the development of the tribunician intercessio. 
tribunician ius auxilii in response to the debt crisis when it is obvious from the Twelve Tables that tribunes could not intervene to save debtors. ${ }^{233}$ This contradiction might be explained if we consider the hiatus of 44 years between the creation of the tribunate and the codification of the laws. By the time the Twelve Tables were set down the power of the tribunes to aid citizens had been refined, as often happens in practice.

While some may have their doubts, no one can deny that the record of the incident in 494 is nonetheless important for the attitudes to the threat of secession it reveals. Livy reports the atmosphere of fear and desire for reconciliation:

Pauor ingens in urbe, metuque mutuo suspensa erant omnia. Timere relicta ab suis plebis uiolentiam patrum; timere patres residem in urbe plebem, incerti manere eam an abire mallent: quamdiu autem tranquillam quae secesserit multitudinem fore? Quid futurum deinde si quod externum interim bellum exsistat? Nullam profecto nisi in concordia ciuium spem reliquam ducere; eam per aequa, per iniqua reconciliandam ciuitati esse. $(2.32 .5-7)^{234}$

233 Forsythe (2005: 173).

234 "A great panic seized the city, mutual distrust led to a state of universal suspense. Those plebeians who had been left by their comrades in the city feared violence from the patricians; the patricians feared the plebeians who still remained in the city, and could not make up their minds whether they would rather have them go or stay. 'How long,' it was asked, 'would the multitude who had seceded remain quiet? What would happen if a foreign war broke out in the meantime?' They felt that all their hopes rested on concord amongst the citizens, and that this must be restored at any cost." 
And so Livy expresses the desire for concordia in terms that his contemporaries in the late Republic and early Empire understood. Cicero immediately springs to mind, with his obsession with achieving concordia between the senatorial and equestrian orders.

The plebs demonstrated their frustration at further magisterial refusal to respect their recently won rights and withdrew their services in a second major incident. This second secession was provoked by the refusal to step aside of the tyrannical second decemivirate appointed to draw up the last of the Twelve Tables. Livy (3.34) passes quickly over the first board of ten set up to codify the law. The little he relates, however, is interesting for its democratic flavour: the decemvirs address the populus in contione and encourage the citizens to go away and discuss the laws so that they could be emended to reflect popular opinion prior the vote in the centuriate assembly. ${ }^{235}$ He focuses instead upon the conflict between the decemvirs, senate and plebeians. Although a second ten men were appointed to complete the final two tables (perhaps to address the issue of limiting consular imperium, on which see below), popular rights were instead eroded further: the decemvirs acted like tyrants under the leadership of Appius

235 Forsythe (2005: 213) suggests that the Twelve Tables provided codification of laws hitherto interpreted by the pontiffs. The laws offered, amongst other rights, limited protection from the harshness of debt bondage. As Cornell (1995: 282) notes, while this still allowed for some rough treatment by today's standards, regulation of punishment was preferable to arbitrary action. 
Claudius. They intimidated the plebeians, and at first also senators, with their lictors' rods and axes, even removing the right of appeal (3.35), and stripped tribunes of their powers, scourging and beheading those who tried to stand in their way (3.36-37). This provided the motivation for the second secession. The decemvirs were so detestable that the plebeians longed to return to the days of the consuls of whose powers they had just recently been so critical. The plebeians also believed that the senate had betrayed them and answered the summons of privati (for the decemvirs' term of office had ended) to assemble and advise them on how to deal with the war against Sabines and Aequi (3.38). Senior senators hoped that the war and push to replace decemvirs with consuls would make the soldiers and plebeians forget about the restoration of tribunes' powers (3.41). But they were not so easily distracted: the first mention of secession came from L. Siccius. He was, however, assassinated before he could convince the soldiers with whom he campaigned to mutiny. He had secretly suggested the election of tribunes and a secessio (3.43). But what really inspired the soldiers and city dwellers alike was Verginius' appeal following Appius Claudius' outrageous treatment of Verginia. Verginius was a highly esteemed soldier, which may have helped attract the following of 400 men who accompanied him to the camp; that and the disgust they felt at Appius' enslavement of the girl (3.44-50). And so the soldiers occupied the 
Aventine, demanding the return of libertas, the election of tribunes and that L. Valerius Potitus and M. Horatius mediate an agreement (3.50.13-16).

The combined pressure of the secession and the newly elected tribunes of soldiers, ${ }^{236}$ compelled the senate to act. Senatorial decrees were passed dissolving the decemvirate, providing for the election of tribunes of the plebs and giving amnesty to those who had seceded (3.54). The liberatores Valerius and Horatius were elected consuls and set about righting the state through the passage of a raft of laws granting significant concessions to plebeians: by the leges Valeriae-Horatiae plebiscites were binding on the whole people, the plebeians' ius provocationis and ius auxilii were restored and strengthened, everyone was reminded of the sacrosanctity of tribunes, and plebeian aediles were given the responsibility of caring for decrees of the senate in the temple of Ceres (Livy 3.55; Cic. Rep. 2.54; Brut. 54). ${ }^{237}$

Forsythe is skeptical of the historicity of the second secession. As in the first secession he finds there are too many parallels and coincidences which point

\footnotetext{
236 These military tribunes were appointed for the first time at Verginius' suggestion to provide leadership for the soldiers, along with another ten elected by the army sent against the Sabines, two of whom were then elected to direct affairs on behalf of the soldiers (Livy 3.51). Some would query the historicity of this episode, supposing it aetiological. Yet every office has an origin, and military tribunes were undoubtedly created to help commanders organise soldiers.

${ }^{237}$ For plebeian aediles as archivists, see Cornell (1995: 263 f.).
} 
to our sources confusing these with other events: the second secession once more involved an Appius Claudius; a Valerius and a Horatius were the first ever tribunes in 509; and the demise of second decemvirate reminds Forsythe of the overthrow of the 30 tyrants at Athens. ${ }^{238}$ Yet in other cases he dismisses incidents as unlikely because they are unparalleled, including the conflict of the orders. ${ }^{239}$ He also believes the Valerio-Horatian law of 449 reinstating the right of appeal was redundant given that the right was already stipulated in the Twelve Tables. ${ }^{240}$ A final qualm he has regards the original unsuccessful rogation of 462 (and the ensuing years of pressure) which Livy records was motivated by the desire to control consular power

\footnotetext{
238 Forsythe (2005: 222).

239 Forsythe claims the conflict of the orders was unparalled and so unlikely to have occurred, in his review of Cornell (1995) in BMCR 97.3.26 : “On p.265 [Cornell] significantly observes: "The plebeian movement was a remarkable phenomenon, as far as we know without parallel in the history of the ancient city-state." The mere fact that according to the modern orthodox interpretation the struggle of the orders was otherwise unparalleled in the ancient world should immediately set off alarm bells and arouse grave doubts as to its historical validity." Another unparallelled and therefore unlikely occurrence is the seven Fabian consulships (Forsythe 2005: 195). Forsythe's inconsistent theory that discounts both examples with and without parallels has been noted by Filippo Canali De Rossi in his review of Forsythe (BMCR 2005.08.40). Ogilvie (1965: 451 ff.), noting late Republican anachronisms (454), suggests that we should not believe all the detail, but that the substance of the decemvirate is historical. See also Mitchell (1992) for a novel, and now widely discredited, theory as to why the Conflict of the Orders was made up.
}

${ }^{240}$ Forsythe (2005: 230ff.) also notes laws on the plebiscites were passed 3 times: 449 (Livy 3.55.3), 339 (Livy 8.12.15) and 287 (Pliny NH 16.37, Gaius Inst. 1.3, and Gell. 15.27.4), concluding that the correct formula is that found in the Twelve Tables (ut quod tributim plebes iussisset populum teneret, Livy 8.12.15), the rest misinterpretations. But I find it more likely, with Cornell (1995: 277 f.), that these were not copies but reenactments introducing modifications: after 449 plebiscites may still have been subject to auctoritas patrum or a vote of the comitia populi. The subsequent laws worked at removing these restrictions. 
(Livy 3.9.1-5). Yet no clause related to imperium appears in the Twelve Tables.

Forsythe solves the mystery by suggesting that the decemviri composed the laws "with" rather than "concerning" consular imperium.241 But this does not explain the extended efforts of the tribunes A. Verginius and M. Volscius Fictor who were elected five times in succession (461-457 BC) to deal with the issue (Livy 3.11-14, 3.21, 3.24-25, 3.29-30). It is more likely that the situtation had changed by the time of the second decemvirate. Back in 462 the plebeians had sought to limit consular power, but after the outrages of the second decemvirate their aims had become less ambitious: they now wanted to restore their libertas and see the election of tribuni plebis once more. Indeed, the limit on consular power was still hinted at by Livy as late as $451 \mathrm{BC}$ : the plebeians sought to appoint a second commission of decemvirs because they loathed the name of "consul" as much as that of "king" (3.34).

The second secession was over the issue of abuse of power, only in the end it was not consular abuse, but decemviral. By 449 the extra-legal plebeian union set up in the early fifth century no longer had to rely on self-help and

241 Forsythe (2005: 202). 
unilateral action as it had begun to be integrated with state institutions. Later, the influence of plebeian innovation was such that the patricians even began to imitate plebeian offices and assemblies. From 447 quaestors were elected to assist consuls. Thus, just as the plebs appointed aediles to assist the tribunes, so too now patricians had two sets of magistrates. At the same time the patricians set up their own tribal assembly, the comitia tributa, to elect these quaestors and later curule aediles (from 367). ${ }^{242}$

Florus alone records the existence of a third secession in 445 B.C.: "qui tumultus in monte Ianiculo duce Canuleio tribuno plebis exarsit" (1.17). Livy notes only a refusal to enlist but goes into much greater detail than Florus the epitomator. It is likely Florus mistook this refusal for a full scale secession. The incident deserves analysis nonetheless for the light it sheds on the plebeians' technique. This time agitation was based not on debt as in the past, but on status issues: for the restoration of the right to intermarry ${ }^{243}$ and for "the people to elect consuls from the plebeians or the patricians as

242 Cornell (1995: 265 with n. 91) notes that the source for quaestors (Tac. Ann. 11.22) dates their origin to the regal period, though this may have been a different sort of quaestor.

243 The most likely explanation of this abrupt volte-face is that the ban on intermarriage, designed by patricians to deter wealthy non-patricians from going over to the plebeian side or by plebieans to prevent integration, was opposed by moderate patricians and plebeian leaders with political aspirations (Cornell 1995: 292). Forsythe (2005: 225-229) queries Livy's account of the ban on intermarriage but is not clear on why he objects - he seems not to like the idea because Livy and Dionysius of Halicarnassus used different sources. He concludes the law may have referred to the intermarriage of priests (interpreted as patricians) with plebeians. 
they chose" (Livy 4.2). The consuls tried to distract the plebeians with the old subterfuge of exaggerated reports of war and necessity for a levy, but this was refused by the tribune C. Canuleius who argued that: "It was useless for the consuls to hold out threats in the hope of distracting the attention of the plebs from the proposed law; as long as he was alive they should never hold a levy until the plebs had adopted the measures brought forward by himself and his colleagues" (Livy 4.1.6). He at once addressed a contio, concluding with a threat to refuse the levy: "no one is going to take up arms, no one is going to fight for domineering masters with whom they have in public life no partnership in honours, and in private life no right of intermarriage" (Livy 4.5.6). When the patricians agreed to legalise intermarriage and ignored the request for the consulship to be opened to the plebeians, the tribunes obstructed the levy (Livy 4.6.5). The tribunes and plebs were satisfied when the senate offered them the right to stand for the newly instituted office of military tribune with consular powers, at which point Livy moralises:

Euentus eorum comitiorum docuit alios animos in contentione libertatis dignitatisque, alios secundum deposita certamina incorrupto iudicio esse; tribunos enim omnes patricios creavit populus, contentus eo quod ratio habita plebeiorum esset. Hanc modestiam aequitatemque et altitudinem animi ubi nunc in uno inueneris, quae tum populi universi fuit? (4.6.1112). ${ }^{244}$

244 "The result of the election showed that when men are contending for liberty and the right to hold office their feelings are different from what they are when the contest is over and they can form an unbiased judgment. The people were satisfied now that votes were allowed for plebeians, and they elected none but patricians. Where in these days will you 
As Livy's eyes were clearly wet with nostalgia here, we should probably not believe that every one of the plebeians was as happy as he makes them out to be when he says that having won the chance to vote for plebeians, they elected patricians instead. Indeed, in little over one hundred years, the lex Genucia (below) legalised the election of two plebeian candidates to the consulship, indicating continuing plebeian discontent at patrician monopoly of the office.

The refusal to gather for the levy in 445 highlights the effectiveness of this form of collective action: the tribunes needed the support of the plebs, and so organised the plebs to refuse to undertake military service, with the result that the tribunes achieved their end. First the right to intermarry was reinstated. This was certainly to the advantage of the wealthy plebeians, not their poor cousins, for with the passage of this bill the rich and powerful plebeians were once more able to marry into prestigious patrician families. The right of these same upper class plebeians to hold the consulship took longer to achieve, and was only grudgingly conceded in a diluted measure allowing plebeians to stand for the office of military tribune with consular characterised the people as a whole?" On intermarriage measure see Cic. Rep. 2.63; Livy 4.1.1 - 6.4; Flor. 1.17; Ampel. 25.3. On the right to hold the consulship: Livy 4.1.1-7.1; Dion. Hal. 11.53.1-61.3. See also Livy 4.1.1, 7.3; Diod. 12.31.1; Dion. Hal. 11.53.1. 
power. This concession was of benefit to both the wealthy and poor plebeians: the wealthy gained the advantage of holding the highest office, and the poor the right to vote for who the wanted to elect, rather than being limited by the family candidates belonged to.

In 342 BC soldiers threatened to secede and staged a successful mutiny over debt and patrician domination of the senate (Livy 7.38-42; Dion. Hal. 15.3.515). During the Samnite wars soldiers stationed at Capua had mutinied over land and debt, claiming they objected to defending a city whose population lazed about benefitting from the fertility of the Campanian soil. These soldiers wanted good land such as the Capuans possessed, rather than returning to the harsh debt laws at Rome. This was no minor military affair: the soldiers were marching on Rome suo impetu, not on the impetus of any $d u x$. The matter was considered sufficiently serious that the senate named M. Valerius Corvus dictator, and he saved the day by passing the measures requested by the mutineers. Livy also comments on the severity of the situation: "If all these concessions were really made it is quite clear that the revolt possessed considerable strength" (7.42.2). ${ }^{245}$ The measures to which

${ }^{245}$ Forsythe (2005: 272) calls the sedition fictitious because Livy's narrative mentions both the dictator and the consuls as ending the mutiny but he seems overly sceptical as the section of Livy to which he refers (7.42) is added at the end and forms a summary of other versions of the event, with the conclusion: "adeo nihil praeterquam seditionem fuisse eamque compositam inter antiquos rerum auctores constat" (7.42.7). Oakley agrees with Livy that "there was some sedition" based on this quote, but doubts the details are correct (1998: 363; 362-365 for discussion; 383-388 on the Genucian laws). 
Livy refers were passed by the tribune L. Genucius and consisted of: "a measure declaring usury illegal, whilst other resolutions were adopted forbidding any one to accept re-election to the same office in less than ten years or fill two offices in the same year, and also that both consuls might legally be elected from the plebs" (Livy 7.42.1-2). When agitation occurred in camp, the consul in charge of the army in Campania, C. Marcius Rutilius, used the old divide-and-conquer ruse: the mutiny was solved in part by sending some ring-leaders on furlough, others on special missions, and retiring others from service (Livy 7.39). Magistrates had an established tradition of using warfare and colonisation to distract the seditious elements from civil unrest: to alleviate tension they could declare war on neighbouring territories and send out colonists to conquered areas, ${ }^{246}$ but this may be the first time they used the trick of dispersing soldiers far and wide in this particularly diverse way.

The summary of Livy for 287 BC records the bare outline of the fifth and final secession: "Plebs propter aes alienum post graves et longas seditiones ad ultimum secessit in Ianiculum, unde a Q. Hortensio dictatore deducta est. (Isque in ipso magistratu decessit.)" (Per. 11; Plin. NH 16.37). Q. Hortensius

${ }^{246}$ Dionysius 6.43; 7.12-13. Garnsey (1988: 180) likewise notes Rome's leaders preferred to send men to war who would otherwise have stirred up trouble in the city in response to food or debt crises. 
won the plebs over by introducing a bill granting plebiscites the force of law, thus making them binding on plebeians and patricians alike:

In eodem Laeli Felicis libro haec scripta sunt: "Is qui non universum populum, sed partem aliquam adesse iubet, non "comitia", sed "concilium" edicere debet. Tribuni autem neque advocant patricios neque ad eos referre ulla de re possunt. Ita ne "leges" quidem proprie, sed "plebisscita" appellantur, quae tribunis plebis ferentibus accepta sunt, quibus rogationibus ante patricii non tenebantur, donec Q. Hortensius dictator eam legem tulit, ut eo iure, quod plebs statuisset, omnes Quirites tenerentur. (Gell. 15.27.4) ) $^{247}$

As noted, this is the third law on the strength of the plebiscite, with one building upon the other. The contribution of the Lex Hortensia is perhaps that the concilium plebis gained the right to instruct any citizens including patrician magistrates. ${ }^{248}$

Debt provided the stimulus for the final secession of the plebs in 287 that gave rise to the Lex Hortensia. ${ }^{249}$ Yet it appears the lex opened no floodgate of radical popular legislation. Instead, so the argument goes, it was a triumph of the patricio-plebeian oligarchy because they kept in their hands the means of legislation while getting rid of the last vestiges of patrician

\footnotetext{
${ }^{247}$ Also "ut plebiscita universum populum tenerent" (Gaius, Inst. 1.3).

248 Millar (1989: 143).

249 See Hölkeskamp (2004b: 49-83, esp. 78-81) for the argument that the lex included no debt relief because those drafting the bill considered the matter too inflammatory; the fear was that a clause on debt relief would scuttle the chance for reform in other areas.
} 
obstruction. ${ }^{250}$ But with so few sources extant for this period it is difficult to draw such concrete conclusions. There may have been laws passed through the concilium plebis the record of which has not survived. If so, the plebs were legislating well before the most famous early victory of popular sovereignty in the legislative assembly, namely Flaminius' reform in 232 BC.

Between 494 and 287 BC plebeians used secession, resistance to the draft and mutiny to gain improvements in their rights and in defence of their freedom. Ambitious plebeians then used the break-away plebeian movement to successfully challenge the patrician monopoly on officeholding and ultimately assimilate themselves into a new nobility. It was perhaps this group that benefitted most in terms of increase in political power during this period, yet there is no denying the material improvements gained by all plebeians: the abolition of nexum, the introduction of punishment for usury and the chance to gain land in a colony or viritane allotment are some examples. These benefits brought them closer to libertas and escape from the yoke of elite domination.

We see trends developing in the methods used to achieve plebeian aims, trends which also appear in late Republican protests. Demonstrations were

250 Cornell (1995: 344), citing with favour Hölkeskamp and Eder. 
organised by leaders from among the plebeians, some of whom were exsoldiers, such as the old former centurion who inspired the prelude to the first secession; others were active soldiers such as those who arranged the mutiny in 342 that resulted in the piggy-back legislation of the Lex Genucia. In this a proposal aimed at benefitting debtors was tied to others in favour of the plebeian elite who wanted magistracies to be shared more evenly among the aristocracy. Other leaders were civilian, for instance the tribune Canuleius who led his colleagues to bar the levy in 445 BC (as above).

As we have seen, tribunician obstruction of the draft was witnessed often in the earlier Republic, where it was used as a method to force patricians to agree to demands for land, food, the right to intermarriage, access to the consulship and protection against the imperium of consuls. In another early example from $483 \mathrm{BC}$, the tribune C. Maenius tried to make the senate hold true to a promise of land allotments by preventing the consuls from holding a levy, but the consuls circumvented him by moving the recruitment to the Campus Martius, thus placing the plebs beyond the orbit of the tribunes' ius auxilii (Dion. Hal. 8.87.4ff.). ${ }^{251}$ Resistance to the draft occured also in the second century, but for another reason: unrelenting and unattractive foreign

251 Pompey and Crassus got around the veto of tribunes likewise in 55 (Dio 39.39). 
wars. $^{252}$ In 151 tribunes threw the consuls Lucullus and Albinus into prison when they "dilectum severe agerent nec quemquam gratia dimitterent" - the tribunes had sought exemption from service for amici (Livy Per. 48) and men were so reluctant to enlist that recruits were chosen by lot for the first time ever (App. Ib. 49). ${ }^{253}$ Again in 138 Scipio Nasica and his colleague were hauled off to prison when they opposed the demands of two tribunes to release men from service (Liv. Per. 55; Cic. Leg. 3.20). ${ }^{254}$ Consuls were also imprisoned in 119, 91 and 60. Threats of imprisonment were made in 59 and 55 - and a censor was threatened in 109.

Lily Ross Taylor has examined these incidents in her 1962 study "The Forerunners of the Gracchi", in which she rightly suggests that there was no period of quiescence between 287 and 133 BC, with tribunician activity

\footnotetext{
252 Taylor (1962: 21) suggests men did not want to got to Spain because "it was too far away and service lasted too long", adding that there was also less chance of booty compared to the more lucrative areas of Carthage, Macedon and Greece. She bases these claims regarding the lack of recruits in 154 on complaints made in 184 .

${ }^{253}$ Brunt (1971a: 391 ff.)

254 Taylor (1962: 26, n. 42) calls one of these tribunes, Curiatius (Cicero's "lowest and foulest of all mankind" (Leg. 3.20)), an effective agitator. The evidence for such as claim is sparse, due to very little material surviving on Curiatius. But he did address the consuls at a contio to try to make them introduce a motion before the senate to reduce the price of grain by sending legates out for its procurement, only to be defeated by Nasica who successfully won the plebs over by appealing to his superior knowledge of what was good for the res publica (Val. Max. 3.7.3). Indeed Nasica enjoyed considerable popular support; for when he was led off to prison it was popular pressure (precibus populi) that resulted in the remittance of his fines (Livy, Per. 55). Curiatius (inridens) gave P. Cornelius Nasica the cognomen Serapio (Livy, Per. 55; a servilis apellatio because he resembled a sacrifical assistant of that name: Val. Max. 9.14.3).
} 
peaking for the period in the eighteen years before Tiberius' tribunate. ${ }^{255}$ Although extra efforts were made to reach agreement in times of national emergency, such as with the unpopular bill for enrolling youths under seventeen passed when Hannibal was laying waste to the Italian countryside (Livy 25.5), in overseas wars tribunes were still actively defending the interests of the plebs in the face of conservative, status-quoadhering, opposition. Taylor may be overstating her case when she emphasises the "revolutionary character of the tribune's forcible interference with the draft" - she herself acknowledges that modern historians have not interpreted the tribunes' actions as anything out of the ordinary (bearing in mind that this article was published in 1962). Taylor quotes Smith as the extreme point of view: the tribunes "acted in a constitutional and proper way", for they operated within the limits of the ius auxilii - it was their job to protect the people. ${ }^{256}$ Yet Taylor would argue that the imprisonment of consuls who were trying to conduct a levy was an infringement of consular imperium - an act more serious than the passage of legislation without senatorial authority. ${ }^{257}$ Her theory that seditious tribunes existed before the Gracchi has been criticised by Badian because she

\footnotetext{
255 Taylor (1962: 22) records twenty three "episodes of the tribunate" in these eighteen years, compared to only one episode (of doubtful authenticity) between 166 and 152 .

256 Taylor (1962: 19) with n. 3, citing Smith (1955: 177).

257 Taylor (1962: 26f.).
} 
fails "to recognise the important differences that made their activities trivial and temporary." The significance of the Gracchi lies in their drawing "wider circles into the framework of Republican politics."258 Taylor's study, while making a strong case for tribunician independence and sustained activity in the so-called "quiescent" period, does indeed appear to have exaggerated the seditious element. ${ }^{259}$

Whenever compulsion is used to recruit soldiers some will refuse to fight. Conscription was clearly still in force in the late Republic, especially when large numbers of men were required. ${ }^{260}$ The reaction of Cinna's troops indicates the existence of forced recruitment, and its unpopularity. These men, levied from amongst new citizens, killed Cinna in 84 BC. The exact circumstances are unclear: his death may have been the result of a scuffle that broke out (App. BC 1.78), but we should attribute some of the soldiers' hostility to their being unwilling recruits, or at least unwilling to kill fellow citizens in a civil war. The evidence is as patchy as it is dependent on partisan sources, but there are signs that refusal to fight were still used to

258 Badian (1972a: 669). His criticism is aimed also at Astin, Scullard and others. Taylor (1962: 27) does, to her credit, note that the tribunes in her study lacked the comprehensive programmes of the Gracchi.

259 Taylor (1962: 27) does indeed water down her earlier claims in her conclusion when she states that, with the exception of the imprisonment of the consuls in 151 and 138, tribunician acts were not revolutionary, but their repeated interference in state affairs marked them out as forerunners of the Gracchi.

260 On conscription as common in the late Republic see Brunt (1971a: 408-410) who states that "we can safely assume that conscription was in general use." 
express discontent in the late Republic. Individuals refused to fight: during the Social War, C. Vettienus' punishment was the confiscation of his property and he was put in chains for the rest of his life. He had rendered himself unable to serve when he cut off fingers so he could not hold a weapon (Val. Max. 6.3.3). In 67 the lex Gabinia gave Pompey the power to levy troops to deal with the pirate problem (Plut. Pomp. 25). There were certainly plenty of levies held in preparation for the war between the supporters of Caesar and Pompey. Cicero notes with concern the reluctance of men to respond to the levy, claiming they have no stomach to fight (Att. 7.13.2), and laments the brutality of the levies carried out in preparation for the civil war (Att. 9.19.1). While civil wars may create exceptional circumstances, fighting between armies of Roman citizens was the condition of the late Republic, and so these examples can not be excluded as atypical.

And so Roman Quirites used the three tactics of threat of withdrawal from war, refusal to enlist and mutiny to make the senate sit up and pay attention to their demands. Progress was sometimes slow, such as the development of protection from creditors (still an issue in the late Republic). But no matter how long it took and how often bills were defeated, advances were made. Raaflaub bases his belief in the historical core of the Struggle of the Orders on the evidence of critical social and economic conditions, the inevitable conflict between patrician and plebeians as social groups and 
comparison to parallels in other archaic societies. ${ }^{261}$ It was these conditions that the citizens of Rome reacted to in the early Republic, conditions which persisted throughout the Republic and on into the next millennium.

THE NATURE OF POPULAR DEMONSTRATIONS

Popular pressure employed both violent and peaceful methods. One form of popular expression was demonstrating, which on occasion turned to rioting or mass violence. Not all demonstrations degenerated in this way, however. From the experience of the secessions and challenges to its authority described above, the senate was aware of what elements from within the populus Romanus could do if the senate failed to respect their wishes. The people could resort to the ultimate motivator: the threat of sheer weight of numbers. If violent means were to be employed, the number of supporters, levels of organisation and efficacy of weapons needed to overwhelm those of the opposition. Popular pressure kept senators in line with the threat of violent removal: a man might be lynched by a mob of disgruntled citizens or ripped apart by angry creditors, as happened to the praetor Asellio in 89.262

\footnotetext{
261 Raaflaub (1993: 131).

262 Brunt (1966: 18) traces the progress of violence. On Asellio see Livy Per. 74; Val. Max. 9.7.4; App. BC 1.54.
} 
Yet peaceful pressure often sufficed. Public disturbances were unusual, but increased during the late Republic. Vanderbroeck finds 68 out of 92 instances of collective behaviour between 78 and 49 BC involved violence. ${ }^{263}$ Even though the majority of episodes of collective behaviour involved some kind of violence, their preponderance over more peaceful demonstrations may be the result of historians keeping a record of the more exciting, and therefore more noteworthy, violent examples, rather than the dull successes won in the Forum. Accounts of a small number of these less racy episodes have survived thanks to the publication of Cicero's speeches, letters and philosophical treatises. Indeed the random reasons for the survival of the historical record for this period should make us hesitate to draw conclusions regarding what were even the most common aims.

Demonstrations aimed at expressing popular opinion took numerous forms. Men shouted, jeered and applauded at public meetings, trials and shows. Supporters displayed posters of favoured candidates in the lead up to elections.264 Graffiti were scrawled on the tribunal to encourage Brutus to take action against the tyranny of Caesar (Plut. Brut. 10) and pamphlets

\footnotetext{
263 Vanderbroeck (1987: 218-267). The list, however, is not exhaustive, as Tatum (1990: 105 n. 8) notes: one example excluded was when Curio was cheered while Fulfius Calenus was harassed by jeering (Att. 2.18.1).

264 Dessau 6412a, 6412e , 6418d.
} 
scattered about the Forum stating that it was Ptolemy's wish to have Pompey as a commander instead of Spinther (Plut. Pomp. 49.6). ${ }^{265}$ Members of the aristocracy also had a couple of tricks designed to elicit a response from the crowd. Caesar revived the practice of displaying imagines (ancestor masks) of Marius during Julia's funeral procession in 69. In the process he increased his popularity amongst the people who applauded him for returning the honours due to Marius - when some (unidentified) others expressed their disapproval, the People shouted them down (Plut. Caes. 5.12). ${ }^{266}$ A similar technique can be seen when the prosecution displayed the imago of Saturninus at a contio before Rabirius' trial in 63 in order to remind those assembled that the tribune had been the victim of a SCU (Cic. Rab. Perd. 25). Cicero had already made his play for popular sentimental support by expertly manipulating the crowd, first whipping them into a frenzy, then calming them down (Cic. Rab. Perd. 18). ${ }^{267}$

\footnotetext{
${ }^{265}$ Gregory (1994: 93) suggests slogans and graffiti provide evidence of demonstrators' reappropriation of power (through the formulation of specific written messages) from the official messages designed to exercise power over spectators.

266 Flower (1996: 124) notes how Caesar not only advertised his family's achievements, but also his own political programme. See also Gregory (1994:89) on the use of images to "make and reinforce particular political messages" and (84) on political 'theatre' at funerals.

267 On the event in general (with none of the above detail from Cicero) see Dio 37.26-27. Vanderbroeck (1987: 231) mistakenly believes this is the only time that the author of a speech recorded the public reaction - see also Cicero's speech against Rullus' agrarian proposal in which he acknowledges interaction with his audience: "I see someone who confirms that the will was made" (Leg. Agr 2.41). Similarly, it seems that the crowd murmurs a response: "It seems to me your feelings are moved a little" (2.49, after rousing the people with references to Rullus selling off land won by the ancestors).
} 
Demonstrations needed to be organised to attract the attention of the men who could make a difference - especially senators, as they alone could be rogatores and propose bills - but also those with the leisure and proximity to the voting urns to actually partipate in the vote. There was no point in converging on a spot and shouting for land redistribution, for example, if there was no audience to hear you. For this reason the Forum and the Campus Martius were sensible venues for attracting attention. The Forum bustled with political and private business and was surrounded by arcades and shops,268 while the Field of Mars was the gathering place for large communal meetings (comitia, religious festivals, sacrifices, funerals and military exercises and assemblies) ${ }^{269}$ along with informal recreational pursuits. ${ }^{270}$. On the other hand, some demonstrations were spontaneous efforts which sought the attention of men of influence, such as the food riot in 75 , during which some members of the plebs attacked the consuls on the Via Sacra in the Forum and forced them to flee (Sall. Hist. 2.45; 2.47.6-7

\footnotetext{
${ }^{268}$ Livy 1.35.10; Dion. Hal. 3.67.4

${ }^{269}$ Livy 1.44.1-2; Dion. Hal. 4.22.1-2; Gell. 15.27.5.

270 Strabo, commenting on the remarkable size of the Campus, says "it affords space at the same time and without interference, not only for the chariot races and every other equestrian exercise, but also for all that multitude of people who exercise themselves by ball-playing, hoop-trundling, and wrestling" (5.3.8) - the campus was covered in grass (Ov. $\operatorname{Tr}$. 5.31-32), and was a popular place to visit for other recreation purposes too. See Dion. Hal. 5.13.2, Hor. Carm. 1.8.3-12, 3.7.25-28 and Veg. Mil. 1.10 (for horses and drill ground); Hor. Carm. 4.1.37-40 (for running race). See Wiseman (1993: 222) and TLL III 216.79-217.69 for further references.
} 
M). ${ }^{271}$ In other instances, it is more difficult to distinguish organised from spontaneous demonstrations as the motivating force behind an action can sometimes be concealed, especially once a cause received the support of a member of the elite. Also, the distinction between 'popular' demonstrations and those organised by patrons to make clients advance their cause is not always clear.

Clodius' reputation suffered from the derogative spin often applied to his character and motivation, and so we need to be wary. Cicero is our only source for the composition of Clodius' gangs, ${ }^{272}$ and gangs are clients by another name, or at least a variation on a theme, a development of the role of client. ${ }^{273}$ Clodius is a polarising subject, even splitting the opinion of seasoned scholars. Finley, for instance, at one point criticises his use of "gangs of hired thugs" 274 only to refer to him favourably two pages later (albeit in a footnote) as the leader of "a genuine, and wholly exceptional, movement of the urban poor and dispossessed."275 It seems that one

\footnotetext{
271 Vanderbroeck (1987: 220).

272 Brunt (1966: 23).

273 See Nippel (1995: 38f.) for evidence of the use of armed retainers for self-protection in rural areas. On the widespread use of gangs (and other forms of organised violence), see Brunt (1966), Nippel (1995: 70-78), and Lintott (1999a: 67-88).

274 Finley (1983: 117).

275 Finley (1983: 119 n. 42).
} 
method Clodius included in his repertoire to promote the interests of his movement was the hiring of men to take on the opposition, and this method was also used by his opponents. Evidence suggests, for instance, that Cicero himself hired men to supplement the paramilitary forces of Milo and Sestius (exhausting the generosity of his friends, Att. 4.2.7). ${ }^{276}$ Nevertheless, the orator did not hesitate to use derogatory terms to cast his enemy in a negative light for employing the same tactic. ${ }^{277}$

During the late Republic, there were two main venues for the working out of tensions between senatorial authority and popular sovereignty: the Forum and the Campus Martius. The Forum was the scene of competition between popular and conservative senatorial interests over legislative proposals, most notably at the informal meetings which preceded legislation

276 As noted by Shackleton Bailey (ad loc.) and Kaster (2006: 14 n. 30). In addition, Shackleton Bailey suggests that Cicero's amici paid for Milo's bands in 57 (e.g. Sest. 86). And Kaster (ad loc.) rightly picks up on Cicero's defensive tone at Sest. 127, which implies that Cicero did indeed resort to using gangs of armed gladiators to secure his return to Rome.

277 For instance in the pro Sestio: The most noble youths and the most honest knights were summoned to a contio and exposed to the swords and stones of Clodius' gangs (operae, Sest. 27). Similary, when Cicero alleges that Clodius used the shortage of grain as an opportunity for sedition, the orator claims he was backed by desperati duces and an army of perditi (Dom. 13). Brunt (1966: 24) adds that we should not let Cicero's biased testimony convince us that artisans and shopkeepers required money or incitement to surrender a day's earnings and risk their lives in order to participate in demonstrations when real grievances were the issue. Cf. Nippel (1995: 70): "[Clodius] was surely neither the first nor the only person to mobilize parts of the urban populace, but by employing every available means in so concentrated and unscrupulous a way over a considerable period of time he opened up new dimensions of politics." Nippel (1995: 73) claims Clodius used members of collegia, including respectable tradesmen rather than runaway slaves, gangsters and other such lowlifes. 
(contiones), and, as we saw above, spontaneous demonstrations over food shortage. Trials in the Forum also saw differences worked out, although along more partisan lines than legislative contiones. The Campus Martius too found itself a focus point, occupied the night before elections by men hoping to prevent their opponents from entering (Cic. Att. 4.3). On the day of elections the Field of Mars was, of course, the best spot for demonstrating support for, or opposition to, candidates.

Not only did demonstrations occur at formal events such as elections, legislative assemblies and trials, but also at less formal events: at contiones and games, citizens showed their support for popular favourites amongst the aristocracy, and for hot topics, especially debt relief and land redistribution.

ORGANISATION AND LEADERSHIP

The first leaders of the plebs were the wealthy citizens of plebeian status. In the early Republic, the breakaway plebeian movement attracted leaders from among the wealthy non-patrician clients of patricians. These formed the small group who benefitted from the Licinio-Sextian reforms that did away with discrimination against plebeians and in so doing cleaved the 
citizenship into two competing groups: patricians versus plebeians. ${ }^{278}$ After this, the plebeians fought through a second phase to do away with discrimination against the elite of the new order. They wanted regular access to the consulship, censorship and praetorship, along with an equal share of responsibilities, such as presiding over elections, duties at the time monopolised by patricians. ${ }^{279}$

The political leaders of the fourth century BC governed by virtue of the offices they held, and their repeated tenure of office was dependent on popular appeal and electoral success. This point highlights the fact that the system involved a substantial democratic element. It has been suggested that this popular aspect was largely absent in the later period when the senate controlled the government and the outcome of the annual elections had little effect on the general direction of policy. ${ }^{280}$ Yet we clearly see in the late Republic a revival of the mid-fourth century trend which had witnessed charismatic leaders like Appius Claudius Caecus preferring the

\footnotetext{
278 For this reason Cornell (1995: 292, 339f.) dates the origin of the Conflict of the Orders and the rise of the nobility to $367 \mathrm{BC}$.

279 Hölkeskamp (1993: 21).

280 Cornell (1995: 371) cites the frequency of the repeated holding of the same office by the same individuals in the mid-fourth century as evidence for their position relying on popular support. He examines the tendency in the period before $300 \mathrm{BC}$, prior to the strengthening of the senate, during which a few men held office repeatedly and so guided policy as long as they had popular support, noting that the only other examples of such repeated tenure of office are Marius, Caesar and the emperors.
} 
favour of the people to that of the aristocracy, especially in the figures of Marius, Clodius and Caesar.

The Genucian and Ovinian laws changed the balance of power, moving the direction of policy from these individual magistrates to the senate which now began to assume the role of advisory body. In 342 one of the leges Genuciae ruled that no one could hold multiple offices or the same one twice in ten years, thus curtailing prorogation. This provision was largely adhered to: for twenty years the Fasti show only one (doubtful) iteration and several homines novi enter the lists - only necessity dictated the election of experienced commanders who broke the rules on office-holding during the Second Samnite War. Then c. 339 BC the lex Ovinia transferred the power of enrolling senators from magistrates to censors (Festus p. 289 L) and so created a permanent advisory body, no longer an ad hoc group with an everchanging membership dependent on the whim of the current magistrates. These reforms changed the nature of government, strengthening the senate at the price of the "plebiscitary" political system in which magistrates had directly consulted the people before making decisions and relied on the popular vote for iteration of office. Cornell sums up: "In short, before the Lex Ovinia, the Senate as such did not exist." 281 The combined effects of

281 Cornell (1995: 248). Forsythe (BMCR review of Cornell 97.3.26) agrees that it is wrong to suppose, as many have, that the senate was always the preeminent body it was in the 
these new laws strengthened the oligarchy at the expense of the handful of individuals who had previously dominated office-holding, for it is clear from the Fasti that more men now gained access to magistracies shared amongst a wider, albeit diluted, elite. The suggestion is that the people also lost an important conduit to power with the decline in independent men. Another result of the increase in senatorial influence was that individual magistrates had less power to direct policy after the growth of senate into a permanent advisory body. But as we shall see, magistrates still had a leadership role, although they were not the only ones to organise and mobilise the people.

Veterans played an important leadership role. Above we saw old soldiers featuring as leaders in early agitation for reform such as in events preceding the first secession, although Cornell questions their significance, calling the anecdote of the "distinguished veteran" a commonplace. ${ }^{282}$ But the fact that the figure was based on a recognisable stereotype lends force to the argument for his existence. Indeed, again in the late Republic we find veterans leading peasants to do battle with the rich and powerful after mistreatment over the issue of debt: C. Manlius was an ex-centurion (Dio

middle and late Republic, but he criticises as "too extreme" the way Cornell reduces the senate to a "shadowy non-entity" in the early Republic.

282 Cornell (1995: 267). 
37.30.5) who led the Catilinarian forces in battle (Sall. Cat. 24.2).283 Moreover, we might also find veterans operating in Rome: the transference of the leadership role of veterans after discharge from military to civilian arenas is logical, especially in the case of men of rank such as ex-centurions. Peter Brunt believes that centurions were the natural leaders and spokesmen of troops in revolutionary times, so in a civil context the transition by an excenturion to organising veterans is a natural step. ${ }^{284}$

As we will see in the following pages, men from among the senatorial elite organised a number of these demonstrations. Some politicians depended on popular support for selfish reasons, such as to help settle personal scores with other senators or because they struggled to win senatorial support, and so needed that of the people to achieve their ends. The defining feature of a true popular leader was his promotion of the populi causa. Cicero contrasts C. Gracchus, a man who proposed laws pro plebe, to Sulla, homo a populi causa remotissimus (Cluent. 151).285 While there was no popular party, 286 there were men such as Tiberius and Caius Gracchus who appear to have acted

\footnotetext{
${ }^{283}$ His involvement in the conspiracy is analysed below.

284 Brunt (1988: 274).

285 Cicero also devotes a substantial passage of his speech in defence of Sestius to defining "popularis" (Sest. 96 ff.).

286 As demonstrated by Seager (1972).
} 
more altruistically: these "true" popularis politicians offered the people both material assistance and an ideology based on ensuring that the senate shared power with the people and that popular libertas was not overwhelmed by senatorial auctoritas. ${ }^{287}$ In this chapter I will test Nicola Mackie's thesis that the people of Rome looked to populares to both secure material benefits and promote an ideology of legal protection of popular rights. That is, genuine populares consulted the people's interests and did not treat the populace merely as a more effective means than senatorial support in securing their objectives. 288 Populares offered the people not only distributions of land and food, plus debt relief, but also "the power to protect its own interests, along with an ideology supporting the transfer of power from senate to populace." 289 Mackie agrees with Seager that populares promoted popular rights and power, and proposed bills aimed at extending these. ${ }^{290}$ But she takes the idea a step further, claiming this only makes sense in a political environment where there is an active ideological debate.

\footnotetext{
287 See below, for instance, on the lex Sempronia of 123 BC, ensuring protection from summary execution.

288 Mackie (1992: 50 f.).

289 Mackie (1992: 61 f.).

290 Seager (1972b) examines the use of the word popularis in Cicero in two sections, the first on Ciceronian nuances of the definition in the pro Sestio, the second on the tactics Cicero uses to verbally tackle those of his opponents who claim to be popularis. Seager (331 f.) emphasises the existence of a shared tradition of actions, slogans and values, encompassing constitutional rights and protection of these (libertas, provocatio, laws on voting and sovereign powers of the assembly), plebis commoda (agrarian, corn and colony laws), the tribunate and the imitation of popularis models.
} 
Thus the senate justified its claim to legitimacy by appealing to res publica, mos maiorum and leges; while populares appealed to the same values to justify the extension of popular rights and powers. Populares claimed the senate ran the republic in its own interests, and in order to counteract such senatorial predominance the people should have more power to guide the republic and look after its own interests. They called for popular libertas to balance senatus auctoritas. ${ }^{291}$

Similarly, Morstein-Marx acknowledges that since the patronage model has been found wanting, it is more difficult to deny the "importance of the ideological realm". Patronage, with its "narrow focus on private, interpersonal relationships" fails to explain "the communal, civic manifestations of Republican political life (e.g. elections, legislation, contiones)." While he believes "the optimates/populares distinction lies ready to hand as a way to delineate the ideological content of the political struggles of the late Republic," Morstein-Marx argues that we have no evidence of ideologically opposed debates. In the contra Rullum, for example, Cicero's tactic is not to pit himself as optimate against Rullus the popularis, but to claim that he is the real popularis, not Rullus, so that the contional crowd had to distinguish true from false popularis in the

291 Mackie (1992: 52-59). 
dramatised context of the contio. ${ }^{292}$ Competition in appearing to champion the same popular ideology created "ideological monotony", reinforced by populares and their opponents. ${ }^{293}$ There was "contional ideology" not popular ideology.294 Senatorial authority, however, was not maligned; rather the history of compromise between senate and people was emphasised, along with the idea of the senate's subordination to popular sovereignty. The moral worthiness of the men leading the senate was at issue, not an ideological dichotomy between pro- and anti-senate. ${ }^{295}$ His conclusion is that popular trust and support depended not on ideology and the offering of alternate ideas, but on reciprocal obligation (the popular belief that magistrates would hold good to their promise to the people, implicit in their election, to defend their interests) and personality, worthiness, credibility and the resulting auctoritas. 296

The history of the last 25 years of the Republic is one of competition between senatorial and popular authority, as evidenced by, for instance, the SCU

\footnotetext{
292 Morstein-Marx (2004: 206).

${ }^{293}$ Morstein-Marx (2004: 229 ff.).

294 Morstein-Marx (2004: 239ff.) likens the Roman situation to the symbolist model of democratic politics: today, where governing bodies stage problem-solving shows rather than actually deliver lasting benefits to the regimes' voters.

295 Morstein-Marx (2004: 232).

296 Morstein-Marx (2004: 276 ff.).
} 
(twice the hot topic in 63, with the trial of Rabirius and its use against Catiline) and the issue of privilegia: the granting of dispensations to individuals. A tribune of 67 , Cornelius, tried to pass a bill that would have seen the right to grant privilegia transferred from senate to the people (the senate's decision was meant to be approved by popular vote, but the senate had usurped the power). A watered down version that did not undermine senatorial authority was passed after senatorial protest (providing that a quorum of 200 senators first needed to support the bill in the senate and that grants could not be vetoed). ${ }^{297}$

But senators were not the only men behind demonstrations. To be sure, the mobilisation of popular discontent often required leadership from within the aristocracy, but we must not underestimate the spontaneity and autonomy of the plebs, and overestimate the input of the elite.298 Intermediate leaders of more humble origins were also involved, including ex-solders, duces of operae, magistri of vici and collegia. ${ }^{299}$ That Cicero considered it worthwhile, for instance, to know the names of the mostly freedmen organisers of collegia, such as Sextus Cloelius, indicates not only

\footnotetext{
${ }^{297}$ Mackie (1992: 62 f.). Asconius 58-59 C and Dio 36.39-40 have the details of the row.

${ }^{298}$ Lintott (1999a: xxi).

299 Mackie (1992: 67-71); Nippel (1995: 71-73). See Lintott (1967) on Clodius' use of intermediate leadership
} 
their influence but also that members of the elite were not the only popular leaders. $^{300}$ In addition, a number of popular demonstrations have no recorded leadership. Omission of leaders' names may occur for one of several reasons: perhaps the writer was unable to obtain the name from his source, or the leader may have been considered too insignificant to warrant inclusion by an elite author, or the leader may not have suited the writer's angle. Other leaderless demonstrations were spontaneous reactions: the response to the food crisis in 75 (Sall. Hist. $2.45 \mathrm{M}$.); the shouts and applause that greeted Pompey when he replied to the censor that he had undertaken all the military campaigns demanded by law and all under himself as imperator (during the recognitio equitum, Plut. Pomp. 22); the applause and hissing which greeted Roscius in the theatre (Plut. Cic. 13); the popular affirmation of the oath Cicero made when he lay down his consulship ("I swear in very truth," he said, "that I have saved my country and maintained her supremacy," Plut. Cic. 23) and his happy escort on his walk home after the execution of the Catilinarians (Plut. Cic. 22).

Mackie believed that the role of the more humble leaders was that of organiser on behalf of senators: "there was no simple division between 'manipulative senators', on the one hand, and 'naïve populace', on the other:

300 Nippel (1995: 73). 
there was a whole range of more or less humble people in between, engaged in organising support for popularis senators." 301 Did these more humble people never act without elite inspiration? Vanderbroeck's examination of collective behaviour finds that leaders were at the head of 81 out of the 92 instances he has identified for the period 78-49 BC. ${ }^{302}$ Only two were spontaneous, though others may also have been (he is unsure of the leadership of some, especially in the theatre). He argues that the urban plebs did not act without a magistrate's involvement as they refused to act illegally, without official sanction, which may be true in the case of Catiline (he failed to maintain urban support), although this may have had more to do with rumours that he had recruited slaves to raze the city to the ground. 303 We must, however, question Vanderbroeck's claim; for inspection of the eleven remaining episodes reveals that not all have such official sanction, and some of the 81 examples have non-elite leadership. Non-elite intermediate leaders were sometimes the motivating force, such as claquers in the theatre - indeed they led 18 events (although sometimes with

\footnotetext{
301 Mackie (1992: 68 f.). She does concede, however, that some, especially Caesar, relied more on the exploitation of popularis rhetoric than others.

302 Vanderbroeck (1987: 124-129)

303 Catiline's supporters were a diverse cross-section of society - more than Sallust lets on. See Gruen (1974: 418-422) for a thorough list; Brunt focuses on debtors (1971b: 129). The senate had plenty of support amongst equestrians and plebs (eg. offers to take up arms), yet executed the captured conspirators when they could have been kept under guard. Nippel (1995: 68) suggests they were executed to deter others from joining the insurrection. If he is correct, there was more widespread support for the conspirators than the sources admit to.
} 
an overall leader from amongst the senatorial elite, in particular Clodius). ${ }^{304}$ Intermediate leadership organised and mobilised parts of the urban plebs. ${ }^{305}$ If the elite wanted to regain control of the masses, they needed to both convince them that they were representing their interests and win over these intermediate leaders.

Examination of the motivation of intermediate leaders reveals reasons other than loyalty and suggests some independence. It may even be that, in some situations, people from outside the elite were the motivating force. These men then turned to tribunes and other sympathetic individuals from the senate to back their popular reforms. Take, for instance, the Catilinarian and ex-Sullan centurion C. Manlius. From what little we know of him, it is still possible to see that he was motivated by need and the desire for reform of the justice system, goals that coincided with those of Catiline. Plutarch suggests that Manlius played a prominent role in convincing Catiline to do battle with his opponents: he says that it was the ex-soldiers of Sulla who prodded Catiline to take action (Cic. 14.1-2). Manlius may well have had plans to raise forces against the dominant factions even before he was

304 I will consider below other leaders such as Curio and his anti-Pompeian demonstrations, e.g. in July 59 BC: the spectators at the ludi Apollinares applaud the actor Diphilus' criticism of Pompey's power, then fail to respond at all to Caesar's entrance, but applaud the triumvirs' opponent Curio with a standing ovation led by the equites (Cic. Att, 2.119.3.; Val. Max. 6.2.9).

305 Nippel (1995: 73 and 78) follows Vanderbroeck (1987). 
recruited by Catiline, as Cicero says, to set up camp in Faesulae and declare war on the Roman people (Cat. 2.14, a speech addressed to the Roman people). ${ }^{306}$ He was a Sullan colonist who sought relief from debt both for himself and the plebs whose support he galvanised in Etruria. In addition, he had given up on expecting fair treatment from creditors, praetors and the justice system (Cic. Cat. 2.20; Sall. Cat. 28.4, 33). ${ }^{307}$ Manlius was from Faesulae in Etruria (Sall. Cat. 24.2), and this is where he based his recruitment operation of plebs, latrones and Sullan veterans:

Interea Manlius in Etruria plebem sollicitare egestate simul ac dolore iniuriae novarum rerum cupidam, quod Sullae dominatione agros bonaque omnia amiserat, praeterea latrones cuiusque generis, quorum in ea regione magna copia erat, nonnullos ex Sullanis coloniis, quibus lubido atque luxuria ex magnis rapinis nihil reliqui fecerat. (Sall. Cat. 28.4)

An objective interpretation of Manlius' supporters reveals them to have been the neediest elements of society: impoverished plebs and veterans struggling to make their way in the perhaps alien world of farming. The involvement of latrones, mostly runaway slaves,308 must be questioned, however, for although the involvement of runaway slaves should not surprise us, as these people were desperate to win freedom and the chance

\footnotetext{
306 Appian (BC 2.2) and Asconius (50C) also paints Manlius as recruited by Catiline to enlist soldiers for him in Etruria.

307 Wiseman (2002: 299) notes the perennial nature of the issues Manlius wanted addressed.

308 Ramsey (2006 ad loc.) translates latrones as "brigands" and adds that these were mainly slaves who had escaped from the large estates in the area.
} 
to earn a living, Catiline himself asserts that he refused to enrol slaves, ${ }^{309}$ so this allegation is probably a moralising Sallustian slur. These latrones were more likely tenants who despaired of ever repaying their debts.

Such a comprehensive and coordinated group from Etruria implies that this uprising was not spontaneous, but that discontent had been simmering for some time. Comparative analysis indicates that where there is discontent, diverse groups will join in networks and plan to do something about it, then wait for the opportunity to mobilise. ${ }^{310}$

Tribuni plebis were often the leaders in demonstrations of popular pressure. We can access the voice of the people through these men, elected to promote and defend popular interests, who worked on behalf of the needy via grain, land and debt reform legislation. Tribunes employed a variety of methods to make senators aware of the needs and desires of the people. There are numerous cases of tribunes summoning senators to address contiones at which popular pressure was applied to convince them to oblige the popular will. For instance, $\mathrm{Cn}$. Sicinius, tribune in 76 B.C., trying to restore the powers of the tribunate, summoned the consuls to address a contio in order

309 Gruen 1974: 430).

310 On the nature of social movements in America, see Meyer (2007), esp. chapters 2-4. 
to pressure them into supporting his reform. ${ }^{311}$ Three tribunes in $52 \mathrm{BC}$ held daily contiones aimed at turning the people against Milo following the murder of Clodius: at one they produced Pompey and got him to speak against Milo by asking if he was aware that Milo had plotted against his own life. ${ }^{312}$ Not all targets of this tactic buckled to popular pressure: when Scipio suggested to a contional crowd that Tiberius Gracchus' death was justified if he had planned to overthrow the government, the crowd cried out, and he replied with a caustic remark about their ethnicity rendering their threat harmless: "How can I, who have so many times heard the battle shout of the enemy without feeling fear, be disturbed by the shouts of men like you, to whom Italy is only a stepmother?"313

\footnotetext{
311 In a section on humour in oratory: "When this man, as Tribune of the people, had summoned Curio and Octavius, who were then Consuls, into the Forum, and Curio had delivered a tedious harangue, while Octavius sat silently by him, wrapt up in flannels, and besmeared with ointments, to ease the pain of the gout." "Octavius," said he, "you are infinitely obliged to your colleague; for if he had not tossed and flung himself about to-day, in the manner he did, you would have certainly have been devoured by the flies." (Cic. Brut. 217).

312 Prius etiam quam Pompeius ter consul crearetur, tres tribuni, Q. Pompeius Rufus, C. Sallustius Crispus, T.Munatius Plancus, cum cotidianis contionibus suis magnam invidiam Miloni propter occisum Clodium excitarent, produxerant ad populum Cn. Pompeium et ab eo quaesierant num ad eum delatum esset illius quoque rei indicium, suae vitae insidiari Milonem.(Asc. 51C).

${ }^{313}$ Hic, eum interrogante tribuno Carbone, quid de Ti. Gracchi caede sentiret, respondit, si is occupandae rei publicae animum habuisset, iure caesum. Et cum omnis contio adclamasset, hostium, inquit, armatorum totiens clamore non territus, qui possum vestro moveri, quorum noverca est Italia? (Vell, 2.4.4).
} 
In other instances, popular pressure was more successful. P. Cornelius Scipio won election to the aedileship of $213 \mathrm{BC}$, despite tribunician opposition due to his age, because his popularity convinced the tribunes to change their minds (Livy 25.2.6-8). Scipio Aemilianus likewise enjoyed popular support such that he was elected consul 148 BC although he was not qualified (and was a candidate for the aedileship at the time: Val. Max. 8.15.4; Auct. Vir. Ill. 58.5). Like Marius after him, Aemilianus benefitted from a vigorous letter writing campaign. Soldiers, unhappy with the progress of the Third Punic War, wrote home urging friends and relatives to elect Scipio consul based on his reputation, recently earned, as a military tribune. When the consuls tried to annul his appointment, the people argued that, by the laws of Tullius and Romulus, they were the judges of elections. In addition, a tribune threatened to remove from the consuls the power to hold elections. The senate relented in the face of such pressure and permitted the tribunes to repeal the law for a year (App. Pun. 112). ${ }^{314}$

\section{COMPOSITION:}

\footnotetext{
314 Astin (1967: 64) suggests that Scipio and his friends made sure he was elected consul by spreading the idea that he must be elected otherwise Carthage would never be captured and the war would drag on interminably. Astin also notes in a scathing critique of Scipio's technique that within six years Scipio had won the support of freedmen who hung about the Forum able to gather a crowd and force all issues by shouting and inciting passions (Plut. Aem. 38.4). According to Astin, Scipio deliberately exploited his popular appeal as a political weapon.
} 
A diverse cross-section of the populus Romanus participated in politics. We cannot equate "the people" with the urban plebs alone, as Meier does, because the plebs was not a united body. 315 The case of Tiberius Gracchus and his supporters illustrates the different elements that made up the politically active part of the citizen body. The tribune relied first on the rural plebs, then, when they were busy with the harvest, he worked hard to win the support of those urban plebs who had not joined their country cousins as seasonal workers on the harvest (App. BC 1.14). ${ }^{316}$ C. Gracchus explored all his avenues when turned to people from all over Italy, plus equestrians, soldiers and hungry plebs (App. BC 1.21-23; Plut. C. Gracc. 12). Saturninus used a different tactic when he turned to Marian veterans and equestrians. ${ }^{317}$ Sulpicius had the support of the newly enfranchised citizens who wanted to be enrolled in all the tribes and Marians (veterans,

315 Brunt (1966: 21). Cf. Meier 1997 for the equation of populus with plebs urbana.

316 See Chapter Four for more on Tiberius' supporters.

317 To impress the veterans he proposed a bill assigning each 100 iugera of land in Africa (Auct. Vir. Ill. 73.1). Saturninus sent messengers to the country districts, sure of the support of those who lived there because they had served in the army under Marius (App. BC 1.2930). These may have been the same soldiers to whom Plutarch refers as joining with the needy rabble and securing the election of Marius and the defeat of Metellus (Plut. Mar. 28.5) The equestrians he had through his amicitia with Marius - and his lex de maiestate which delivered to an equestrian jury the power to try cases of maiestas (Auct. Ad Her. 2.17; Cic. De Or. 2.107, 109, 164, 197-201; Inv. 2.53; Part. Or. 105; Sall. Hist. 1.62 M). In his second tribunate he proposed bills on subsidised grain, more veteran colonies, and distribution of land seized from the Cimbri. Refs MRR1: 575. 
equestrians and recalled exiles), 318 while Cinna sought the support of newly enfranchised citizens (App. $B C$ 1.65) and the army. Sulla used his army to march on Rome and recover his command against Mithridates in 88, while Pompey used his army and veterans in 70 to restore tribunes' powers (and in 59 to ensure the passage of Caesar's bills). These soldiers were from the Italian countryside. Likewise, C. Manlius galvinised plebs and Sullan veterans to join Catiline, while in the city the movement had the support of members of every order. ${ }^{319}$ The Catilinarians were a group as diverse as their aims: politically frustrated senators and equestrians, leaders from Italian colonies and municipalities (Sall. Cat. 17.4), veterans, rural and urban plebs. $^{320}$ In contrast, Clodius relied mostly on the support of the urban plebs (Asc. 48 C, Cic. Dom. 54).

The men referred to as the urban plebs during the late Republic were a mixed bunch. They were the inhabitants of Rome from outside the senatorial and equestrian orders. From the time of the Gracchi these city dwellers consisted of men of moderate means who fell short of equestrian property qualification, poor day labourers and the destitute, those in debt or

\footnotetext{
318 App. BC 1.55f; Asc. 64 C; cf. Livy Per. 77.

319 See Chapter Four on the Catilinarian Conspiracy.

320 On supporters, see Gruen (1974: 418-422).
} 
under stigma, dispossessed farmers and a large proportion of freedmen. ${ }^{321}$ The ratio of freedmen to freeborn ingenui in Rome is difficult to determine: all we can tell for sure is that freedmen made up the majority of artisans and shopkeepers in Rome and other large cities. Funerary inscriptions found in Rome are mostly those of freedmen, which suggests that they formed the majority of Rome's inhabitants. But this theory has been questioned and it is now generally agreed that the prevalence of these inscriptions is more likely an indication of freedmen's desire to celebrate and advertise their own success. $^{322}$ This diverse range of men, then, were the urban plebs, crucial supporters to have if a reformer's operations were based in Rome.

CONCLUSION: WHAT KIND OF DEMOCRACY?

We have seen in this chapter that all sorts of citizens participated in political reform, decision-making and policy development, regardless of property

321 Scheidel (2008: 17-70) analyses the logic of the demographic debate. See De Ligt (2004) on population growth fuelling the rural misery behind the Gracchan reforms. See also Rosenstein (2004: 10-13); Brunt 1971a; Lo Cascio 1994 and 2001; Scheidel 2004 and 2005. Keaveney 2007: 21 critiques Rosenstein regarding the reliability of census figures in the $2^{\text {nd }}$ century.

322 D'Ambra (1988: 99) in her study of two tombs in Ostia concludes that the aim of the decoration on the façade was to remind the public of the achievements of the deceased. See also the comments of Welch (2007: 507-509) regarding the so-called Tomb of the Baker: the tomb of a freedman, it celebrates not only his career, but also features figures of his wife and himself out of proportion to the surrounding bread-making apparatus. Welch remarks upon this "career relief", a development of the late Republic: "The (mostly nouveaux riche) patrons often wished to include as much self-advertising material as possible in the relatively small space available to them" (509). 
qualification. The long drawn out process of reform has encouraged students of the late Republic to ignore the progress made, and the success of the people involved in achieving reform. The success of collective action to achieve its goal of expressing the opinion of those involved, so that material and ideological interests of these citizens were advanced, is an indicator of the existence of democratic elements. In terms of raw figures, Vanderbroeck claims that 65 out of the 92 cases of collective behaviour he surveyed between 78 and 49 BC achieved their goal. ${ }^{323}$ We do need to bear in mind, however, the effect of making any calculations based on fragmentary sources.

In the following chapter, we investigate the role of these Roman citizens in the decision-making process by way of case studies on food supply, the restoration of tribunicia potestas, debt relief and agrarian reform.

323 Vanderbroeck (1987: 161 ff.). 


\section{CHAPTER 4: DEMONSTRATIONS AND COLLECTIVE ACTION II:} FOOD SUPPLY, RESTORATION OF TRIBUNICIAN POWER, DEBT RELIEF AND LAND REFORM

The following case studies aim to evaluate through the examination of incidents of collective action the degree to which Roman citizens were able to improve their material situation and protect their libertas. ${ }^{324}$ In order to defend my thesis that these people did have political power, I will look at the effectiveness of the action taken. A demonstration will be deemed a success if measures were taken to address the problem over which the demonstration originated. Consideration of leadership might also reveal that political power was not limited to members of the elite insomuch as leadership was provided by men not registered in the top property classes but included ex-centurions, heads of collegia and vici leaders. Citizens outside the aristocracy were able to take action that resulted in material improvement to the quality of their life.

Consideration of the role of non-elite Romans is important, in order to deal with the objections of those who claim that any change to the status quo was driven by ambitious demagogues and that an ideology of redistribution of

324 See Chapter One for a discussion of who the Roman citizens were. 
resources played no part in the politics of the late Republic. Gelzer was incorrect to introduce the idea that Republican politics operated in an ideological vacuum. ${ }^{325}$ Rather, Roman politicians did take sides on matters of principle, although they changed sides as it suited. There existed fluctuating factions: some men were optimates, some populares, most were either, depending on where the advantage lay. ${ }^{326}$ But this factionalism does not negate the existence of an ideology based on popular principles.

\section{CASE STUDY: FOOD SUPPLY}

Food shortages were common in Rome during the Republic, the result of the growing demands of an increasing population in a city without the infrastructure to ensure regular adequate supply of grain, complicated by slave revolts, pirates, civil strife and increased numbers of legions. ${ }^{327}$ In these times of shortage when the usual supply gathered from the Italian peninsular or paid as tax by provinces (Sicily, Sardinia, Hispaniae and

\footnotetext{
325 Wiseman (2002: 306).

326 Wiseman (2002: 293) takes a rather extreme stance when he argues that there clearly existed optimates (Sallust's nobilitas) and populares, not just the former: "the Republic was divided into two rival ideological camps - two partes, as [Cicero] put it in a speech to the Senate - and that this rivalry had been fundamental in Roman politics since the time of the Gracchi."

327 Garnsey (1988: 195 -206). See Livy 2.34.1: following the first secessio plebis the consuls had to send men out to Etruria, Cumae and Sicily to buy grain because the fields had been neglected during the secession.
} 
Africa in particular) dried up due to a drop in production or disruption to supply, the city relied on legates, aediles, quaestors from grain-producing provinces, $^{328}$ specially appointed commissioners, ${ }^{329}$ along with other magistrates and promagistrates to purchase supplementary food, with mixed results. ${ }^{330}$

It was in such an environment of patchy supply that the hunger of the people motivated Gaius Gracchus as tribune to first institute a system of grain procurement and subsidy in 123. His lex Sempronia also provided for the establishment of state granaries to store surplus and so ensure supply in times of poor harvest or interruption of supply, although there is no evidence that these were ever built. ${ }^{331}$ He was perhaps inspired by the system set up by Scipio Aemilianus in 134 to supply soldiers with rations using granaries in Numantia. As quaestor in Sardinia 126-124, Gracchus had also seen food shortage there such that he had been compelled to use family connections in Numidia to secure grain for the forces stationed with him.

\footnotetext{
328 E.g. In 75 BC , when grain prices were extremely high, Cicero was quaestor in Sicily. He sent grain home to Rome (Cic. Planc. 64).

329 E.g. L. Minucius was appointed praefectus annonae in 440 in a period of such severe famine that plebeians were throwing themselves in the Tiber (Livy 4.12.8-11, 4.13.7-8; Dion. Hal. 12.1).

${ }^{330}$ Veyne (1990: 236 ff.).

${ }^{331}$ Rickman (1980: 138-140) demonstrates that private horrea were hired for storage of state grain surpluses.
} 
Appian tells us that the aim of Gracchus' law was to regulate the food supply: the lex provided for a regular monthly distribution ( $B C$ 1.21). Secondary sources conclude from the weight of this and other rather fragmentary evidence that Gracchus proposed the reform to ensure there was food for hungry Romans: Rickman, Garnsey and Rathbone argue the aim of the lex Sempronia frumentaria was to fix the problem of unreliable food supply from Sardinia, Sicily and North Africa. 332 Veyne agrees that "his aim was a guaranteed subsistence, not an equal division of gains amongst all payees or a reduction of relative inequality." 333

So, we can agree on his aim, but what of Gaius' motivation? It appears that ideas of fairness did play a part in his reform, but it was not that Gaius and his plebs had a principle in mind. Rather, they "were developing an ideology, an allegory of justice in which the body politic was likened to a share-issuing company, in order to make more concrete the idea that tout le monde a le droit de vivre." 334 Rickman interprets Gracchus' actions as altruistic

\footnotetext{
332 Rickman (1980: 158 ff.); Garnsey and Rathbone (1985).

333 Veyne (1990: 241).

334 Veyne (1990: 241 f.). I cite the original French edition (1976: 452) to clarify the ambiguity of the translator's interpretation of vivre as "livelihood". This seems to me a misleading translation as it gives the impression that the Gracchans believed everyone should be entitled to a "means of living" (Concise Oxford Dictionary, $7^{\text {th }}$ ed.), whereas Veyne clearly intended vivre to be taken as "life", i.e. everyone had the right to life - in this context, access to subsistence levels of food that ensured life.
} 
- "an act of humanity." 335 The sources include so little detail that it is impossible to tell if he acted in response to popular pressure or to avert public unrest. Either way, the hunger of the people motivated the reform.

Gracchus may also have been aware of a secondary implication of the introduction of state subsidised grain. Not only was his grain law designed to promote price stabilisation, but also to weaken patronage and restore the independence of Roman citizens. In a time of food shortage those with rich patrons could turn to them. Therefore Gracchus may have been trying to compete with the handouts given by rich patrons to their clients. With the state providing grain, politicians could no longer buy votes with the promise of cheap food.

The dignitas derived from supplying the people with food was jealously guarded, so great was the popular following, and so power, that could accrue to a reformer. C. Gracchus introduced his measure as tribune, and so avoided the mistake made by $\mathrm{Sp}$. Maelius. The wealthy equestrian responded to a famine in 440 by making free grain handouts as a private citizen from his own purse. It was alleged that he sought to usurp supreme power once he had won the support of the plebs in this way. The magister

335 Rickman (1980: 161). 
equitum C. Servilius Ahala chased him down and, surrounded by a crowd of young patricians, slew Maelius, who died appealing to the plebs for protection (Livy 4.13-16). Maelius' case indicates that large-scale free handouts could only be made with official sanction. Privati were not allowed to participate, as Maelius' fate illustrates, so fiercely protected was the dignitas gathered by such popular activities.

The nature of Gaius' reform makes it unlikely that he sought to win the support of the people at the expense of losing that of the aristocracy, some of whom considered provision of support to clients an elite prerogative and so opposed state intervention in the food supply. But it was inevitable that he should upset rich patrons who saw their means of gaining prestige cut off. It was one thing for the state to provide a quaestor to manage the food supply, but quite something else for the state to provide the people with cheap food. The magistrates responsible for food distribution, and even those who administered its supply, gained in popularity and dignitas, as it was these state authorities who now fed Rome. Cicero, for instance, credits Saturninus' becoming a demagogue to his removal from office as quaestor in annonae caritate, so great was the insult to his dignitas (Har. resp. 43; quaestor Ostiensis, Sest. 39). ${ }^{336}$

336 Saturninus' job had been to arrange the transport of food from the port to the city (Diod. 36.12). 
Indeed, Garnsey considers this removal of the opportunity for acts of benevolence from individual aristocrats to the state to be one reason for considering the Gracchan reform a revolution. ${ }^{337}$ However, he exaggerates: the system had not changed enough to justify the term revolution. Wealthy individuals were still able to augment their popularity and increase their auctoritas by procuring grain for the people, as Cicero did when he was quaestor in Sicily (Cic. Planc. 64). There were other forms of euergetism too. Generals gave donativa to soldiers, candidates gave gifts to electors, aediles provided games, while other aristocrats built granaries and public buildings. Nor did the new system of grain distribution persist long enough to fulfil the definition of revolution in the sense of new way of government. Perhaps what Garnsey intended to say was that Gaius Gracchus' statesubsidised grain ration was among the first wave of reforms to pit reformer against conservative, and so pave the way to the end of consensus politics. Taylor suggests this in her study of tribunes active in the years immediately preceding the Gracchi: unlike their forerunners, although they followed their lead by interfering in state affairs, the Gracchi were unwilling to compromise. ${ }^{338}$ One thing is clear: bills certainly became the battleground

\footnotetext{
337 Garnsey (1988: 197).

338 Taylor (1962: 27).
} 
for personal competition affecting individual dignitas amongst the senatorial elite.

The next food bill we have any significant information on is that of Saturninus. ${ }^{339}$ In $100 \mathrm{BC}$, the tribune proposed that corn be subsidised. The price at which it was to be sold is not clear. Our main source says $5 / 6$ as per modius, but this is likely a copyist's error: de senis et trientibus misread as de semissibus et trientibus. ${ }^{340}$ If, then, Saturninus' proposal was to provide corn at the same subsidised rate as the lex Sempronia we must conclude that during the intervening years Gracchus' law had ceased to operate. In the end, Saturninus' bill probably failed to be passed into law: his colleagues vetoed his rogatio and, when he pressed on, Caepio broke up the pontes and overturned the voting urns (Ad Her. 1.12.21). Why did Saturninus put forward this rogatio, especially against such open opposition? It may have been that the distributions had ceased and needed to be revived. Another possibility is that it was part of his competition with the conservative elements of the senate - he was fighting for popular support, which, once added to that of the Marian veterans, would have given him the power to take on the optimates. One thing is certain: there was a strong demand for

\footnotetext{
339 Plutarch makes passing reference to Marius opposing a law which proposed a distribution of corn during his tribunate in 119, but provides no further detail (Mar. 4.4).

340 Our source: Auct. Ad Her. 1.12.21. Rickman (1980: 163) suggests the correction.
} 
the distributions. M. Aemilius Lepidus also tried unsuccessfully to reintroduce the practice in 78 , following Sulla's cancellation of the subsidy thanks to Sulla the Roman People did not even retain the "rations of slaves" (servilia alimenta, Sall. Hist. 1.55.11 M).

There remain four laws and decrees to examine: the first, a law proposed in 73 by optimates in response to extreme popular pressure expressed by riots in 75; then a decree influenced by Cato in 62 (he was eager to win popular approval as long as Catiline remained armed and dangerous); the third was Clodius' radical free grain dole of 58; and finally, the law giving Pompey charge of the grain supply for five years. From these we can see the effects of popular pressure applied successfully to both popular and conservative leaders.

Popular pressure resulted in the senate reinstituting the grain subsidy on a small scale in 73 . Following riots in 75 that saw the consuls chased down the Via Sacra, the senate responded by having the consuls of 73 propose another lex frumentaria which stipulated that 5 modii per month be sold to citizens at the same price as Gaius Gracchus' distributions. This lex TerentiaCassia proves the effectiveness of popular pressure. Brunt agrees that outbreaks of mob violence were directly related to food shortages, although 
he acknowledges the lack of data. ${ }^{341}$ The provision of subsidised grain was not the only response to the food crisis: Antonius was also sent against the pirates who were interfering with the supply. When his efforts did not solve the problem, the people voted Pompey command against the pirates in 67. Cicero emphasises the degree of popular pressure behind his appointment:

The whole Roman people (universus populus Romanus), the Forum being crowded, and all the adjacent temples from which this place can be seen being completely filled - the whole Roman people, I say, demanded Cnaeus Pompeius alone as their general in the war in which the common interests of all nations were at stake. (Cic. Imp. Pomp. 44)

The extremely high level of attendance, well above the norm, indicates the dire need for action to be taken to secure supply routes. It also points to Pompey's popularity. Dio relates that the people supported Pompey's appointment with such passion that, when word got out that the senate did not share the popular opinion, the people would have attacked the senators in the curia if they had not got out of the way (24.2). The price of grain fell on the day his command was announced and markets were soon overflowing with food (Cic. Imp. Pomp. 44; Plut. Pomp. 26.2, 27.2). Such sudden plentiful supply suggests that not only pirates but also grain speculation was to blame for the shortage: merchants held stores back to

341 Brunt (1966: 26) agrees with the findings of Rudé (1981). 
cause short supply and so force prices up. Pompey dealt with the pirates by securing the supply lines from the main grain producing regions of Sicily, Sardinia and Africa. Within forty days the seas were free of pirates and supplies secured (Cic. Imp. Pomp. 34; Liv. Per. 99; Plut. Pomp. 28; Dio 36.37.3; App. Mith. 95; Flacc. 29 f).

Popular leaders competed with the senate for the favour of the hungry. In the events of $62 \mathrm{BC}$ we can see how the threat to the status quo posed by Catiline's attractive proposal to deal with debt sent the more conservative members of the senate into a panic. M. Cato convinced the senate to give the poor citizens a monthly allowance of grain at a cost to the treasury of 1250 talents (Plut. Cat. Min. 26.1; Caes. 8.4). Cato's law must have subsidised grain so it was only costing the buyer $61 / 3$ asses, for Cicero moans that under Clodius' measure in 58 "nearly a fifth of the public income was to be lost by lowering the price of grain by $61 / 3$ asses per measure" (Sest. 55). Also, Asconius (8C) records that Clodius' law provided grain free of charge instead of $61 / 3$ asses per modius. That the senate passed a decree admitting "the poor and landless plebs" to the list of eligible recipients (Plut. Cat. Min. 26.1), suggests that they had been removed from the lists at some point (by the lex Octavia ${ }^{342}$ or the lex Terentia-Cassia). The identity of

342 Octavius, an optimate, replaced Gracchus' subsidised distributions with a less generous amount, maybe limiting the number of recipients. The date of the lex Octavia is unclear: 
those removed is unclear: Brunt suggests freedmen were targeted. ${ }^{343}$ Rickman calculates that Cato doubled the number of those eligible. ${ }^{344}$ Plutarch implies the Senate had to do something to steal the support of the poor and landless from Caesar, who had "proceeded to stir up the most corrupt and dissolute elements of the state to form a party in his support" the corrupt and dissolute are equated in the next line with the poor and landless (Plut. Cat. Min. 26.1). Rickman's reasoning is more convincing: the senate needed to increase the number of recipients to compensate for the appeal of Catiline. The poor could not be ignored. The senate had to pass measures to address the interests of the many or face losing them to the other side.

Clodius introduced the first ever free grain dole in 58 BC. ${ }^{345}$ That he should attach this proposal to a raft of popular legislation emphasises the pressure from his supporters among the urban plebs for more generous provision of food. Such was the appeal of free food that rural poor immigrated to Rome

Brunt (1971a: 377) places it between 121 and 119, but Rickman reckons it to be after 100 (1980: $161 \mathrm{f}$.)

${ }^{343}$ Brunt (1971a: 377, 379).

${ }^{344}$ Rickman (1980: 170 f.).

345 Cic. Sest. 55; Dom. 25; Asc. 8 C; Dio 38.13; Schol. Bob. 132 Stangl; Plut. Cic. 30. 
and masters felt encouraged to free slaves. ${ }^{346}$ Some of these no doubt attached themselves as clients to Clodius, their patron and provider. The impact of more eligible recipients (plus poor harvests) put pressure on the supply - complicated also by merchants' reluctance to deal with Clodius' agent Sextus Cloelius, who had been put in charge of the entire grain supply (corn lands, contractors and storage). ${ }^{347}$

As a consequence of the influx of immigrants and the supply issues, there was by 57 BC a severe shortage of grain. The plebs vented their frustration by rioting twice this year: first at the ludi Apollinares in July and then at the ludi Romani in September. The first demonstration is recorded only in Asconius' commentary on the Pro Milone. He calls the participants "infima coacta multitudo", a collected multitude of the basest men, who caused a stir at the price of grain and expelled all the spectators from the theatre (Asc. 48 C). Even taking Cicero's bias into account, for there is no doubt Asconius' commentary reflects the tone of the original speech, 348 we should not be

\footnotetext{
346 I agree with Brunt (1962: 69 f.) who interprets Sallust's comments regarding the influx of agricultural labourers to Rome tempted by the dole (Cat. 37.4-7) to be anachronistic, referring not to the $60 \mathrm{~s}$ but to the situation during the time he was writing, following the Lex Clodia. Another reason to interpret Sallust's comments with care is that in this section he is making a case for the corrupt state of Roman society, not the place to find objectivity. Rural poor moved to Rome, and masters freed slaves, for other reasons too, of course.

347 Rickman (1980: 173 and 5), citing Cic. Dom. 25.

348 Marshall (1985: 47) notes that not only does Asconius hesitate to disagree with Cicero even when the orator makes mistakes, but he also tends to accept Cicero's statements at face value, adopting Cicero's use of pejorative terms for instance.
} 
surprised that it is the infima multitudo who are the first to feel the effects of expensive food. It appears that the state supply had dried up and the crowd was protesting at the price of private suppliers. ${ }^{349}$ This demonstration was not spontaneous, as indicated by coacta, but there is no hint in Asconius as to who organised the demonstrators. Vanderbroeck suggests the leader was Clodius as it was he who organised the second riot (see below). ${ }^{350}$ The demonstration was a success as the price of food dropped shortly after the event. Not everyone, however, agrees that the demonstration was responsible for the price decrease. Cicero gave himself the credit. He suggests that the price fell because "in meo reditu spes otii et concordiae sita videbatur" (Dom. 15) following a senatorial decree proposing a bill for his recall (Dom. 14; Sest. 129). In a speech to the people, he announced that the abundance and cheapness of corn was proof that the gods approved of his restoration (Red. pop. 18).

We have much more detail on the demonstration at the ludi Romani thanks to Cicero's involvement. ${ }^{351}$ He had just returned from exile and the grain

\footnotetext{
349 See Garnsey (1988: 203) for factors contributing to the shortage: speculation, harvest failure, the influx of people supporting Cicero's return from exile (to whom I would add those attending the games), and the increased amount of recipients eligible for Clodius' dole.

350 Vanderbroeck (1987: 247).

351 Vanderbroeck (1987: 249-251).
} 
supply was precarious, both expensive and scarce. Dio paints a chaotic picture of desperate hunger involving more than just the most desperate infima plebs who featured in the previous example. This time the situation had worsened so that hunger drove a great throng of people to seek the attention of the senate:

A sore famine had arisen in the city and the whole crowd (tou homilou pantos) rushed into the theatre and afterwards to the Capitol where the senators were in session, threatening at first to slay them with their own hands, and later to burn them alive, temples and all. (39.9.2)

According to Cicero, the senate was discussing the shortage of food at the time (Att. 4.1.6-7). Cicero once more reduces the participants of the riot to the more humble, although this time not the infima plebs. ${ }^{352}$ The plebs pelted the senators with stones:

If that [stoning] arose from the indignation of the common people (ex dolore plebei), without any one having stirred them up, it is a great misfortune; but if it was caused by the instigation of Publius Clodius, it is only the habitual wickedness of a wicked man: if both these causes existed, if there was both a fact sufficient of itself to excite the feelings of the multitude, and if there were leaders of sedition ready and forearmed, then, does it not seem natural for the republic to have had recourse to the protection of the consul and the loyalty of the senate? But it is quite plain that one of these causes did exist; that there was a difficulty obtaining provisions, and an extreme scarcity of corn, so that men were afraid not only of a continuance of high prices, but of actual famine. No one denies it. But I do not wish you, $\mathrm{O}$ priests, to suspect that that enemy of all

352 See below for the involvement of tabernarii, that is, men who were by no means destitute, but well enough off to run a shop, although lacking, of course, that landed property required to, as Mouritsen (2001: 140) has put it "give them freedom and preserve their dignity and honour." 
tranquility and peace was likely to seize on this as a pretext for conflagration, and massacre, and rapine, unless you see it proved. (Dom. 12)

The orator alleges Clodius along with his armati duces Lollius and Sergius were responsible for inciting this violence, but note his hesitance in blaming them outright. This should make us wonder if he had watertight evidence of Clodius' role. Cicero's obfuscation may be attributed to rhetorical trickery, an effort to encourage his audience to convict Clodius themselves by shying away from doing so himself. ${ }^{353}$ Yet the possibility remains that Cicero was grasping at straws and had no proof that Clodius was behind the demonstration. Q. Metellus fingered Sergius and Lollius for their involvement (Dom. 13), but that is not the same as identifying Clodius as protagonist.

Analysis of Cicero's depiction of L. Sergius and M. Lollius reveals the technique used by leaders to organise demonstrations. Amid the slurs

\footnotetext{
${ }^{353}$ Craig (2007: 266) observes that the tension between Cicero the persuader and Cicero the model public figure opens Cicero up to the charge of self-promotion, or, as here, selfpromotion via denigration of the foe, and notes the danger to the speaker of calling his bluff: "As exemplar of persuasion, the text invites us to imagine the speech as an oral performance before a specific audience, to assess Cicero's persuasive goals and the challenges that he must overcome to achieve them, and to see our text as a representation of an act of the progressive manipulation of the audience. This is the essence of persuasive process criticism. But the depiction of Cicero the persuader is also the self-presentation of Cicero the model public figure. This self-presentation may be seamlessly integrated with the depiction of an oral persuasive act. But it may also weaken or break the illusion of oral performance, leaving the reader to judge it as a literary exercise in self-promotion cast within an oratorical genre."
} 
Cicero slings at Sergius, we discover he was "the exciter of the shopkeepers" (concitator tabernariorum) and that Clodius used "these leaders and others like them at the time when provisions were dear, under pretence of espousing the cause of the poor and ignorant, [to prepare] for sudden attacks on the consuls, on the senate, on the property and fortunes of the rich" (Dom. 13). A reconstruction of the demonstration sees Sergius organising tabernarii to protest against the scarcity of grain. Cicero purposefully misinterprets the attention the demonstrators pay to the consuls, senate and rich as a direct attack on their safety when a more honest (and fruitful) approach is to interpret these influential men as the obvious audience to be addressed by those seeking economic assistance.

Cicero complained that Clodius enlisted slaves and gladiators to massacre the boni, but that the multitude cried out for Cicero, "the guardian and defender of the Capitol and of every temple," to intervene (Dom. 5-7). ${ }^{354}$ Thus he paints himself as the saviour of the state, much as he did when it came to his involvement in the Catilinarian Conspiracy:

When the senate, in a very full house assembled in the temple of the allgood and all-powerful Jupiter, had passed a decree touching my dignity with only one dissenting voice, all of a sudden, on that very day, a most unexpected cheapness followed a time when corn had been excessively

354 Cicero's inclusion of temples here can be explained by the aim of the speech: to justify the removal of the temple dedicated to Libertas which Clodius had erected on the site of Cicero's house. See especially Dom. 141-147. 
dear. Some said, (and I myself am of that opinion,) that the immortal gods had shown their approbation of my return by this exercise of their power. But some traced that fact back, connecting it with this argument and opinion that, as all hopes of tranquillity and concord appeared to depend on my return, and as there was an incessant dread of sedition connected with my absence, so now that all fear of contest was almost at an end, they thought that the state of the corn-market was altered; and, because it again had become more unmanageable after my return, then corn was demanded of me, on whose arrival virtuous men were in the habit of saying that there would be cheapness. (Dom. 14-15).

In the end it was Pompey, with the help of Cicero's rhetorical skills, who saved the people from starvation, as Dio relates:

Cicero now persuaded them to elect Pompey as commissioner of the grain supply and to give him also on this account the office of proconsul for five years both in Italy and outside. So now in the case of the grain supply, as previously in the case of the pirates, he was once more to hold sway over the entire world then under Roman power. (39.9.3)

Dio's account agrees with those of Cicero, Livy and Plutarch: Pompey was given charge of the grain supply (cura annonae) with imperium pro consule for 5 years. 355 The proposal came from the consuls Lentulus Spinther and

\footnotetext{
355“legem consules conscripserunt qua Pompeio per quinquennium omnis potestas rei frumentariae toto orbe terrarum daretur, alteram Messius qui omnis pecuniae dat potestatem et adiungit classem et exercitum et maius imperium in provinciis quam sit eorum qui eas obtineant. illa nostra lex consularis nunc modesta videtur, haec Messi non ferenda. Pompeius illam velle se dicit, familiares hanc." "The consuls drew up a law by which complete control over the corn-supply for five years throughout the whole world was given to Pompey. A second law is drawn up by Messius, granting him power over all money, and adding a fleet and army, and an imperium in the provinces superior to that of their governors. After that our consular law seems moderate indeed: that of Messius is quite intolerable. Pompey professes to prefer the former; his friends [say he wants] the latter." (Cic. Att. 4.1.6-7). The senate decreed Pompey be given HS 40,000,000 for the rem frumentariam (Cic. QF 2.6). "The fruitfulness of the land" was banished along with Cicero (Red. Sen 34). See also Livy Per. 104 (Pompey was assigned supervision of the grain supply for five years); Plut. Pomp 49.4-5 (powers attacked by Clodius).
} 
Caecilius Metellus, but with the opposition of Clodius who alleged the shortage of grain was manufactured to secure Pompey another command at a time when his power was withering away (Plut. Pomp. 49.5). Clodius' charge may have been motivated by a desire for revenge for a similar allegation levelled at him by Cicero, namely that Clodius had exacerbated a period of scarcity by keeping food in storage as a pretext to kindle sedition (Cic. Dom. 11f.). On the other hand, Clodius may have been right to accuse Pompey: the food shortage was solved suspiciously quickly. Clodius' allegations suggest that this was due to Pompey's releasing stores held back to create the necessity for his command, but there is insufficient evidence to corroborate this. It is more likely the surplus was, as Plutarch records, the result of Pompey's efforts: he collected grain personally from Sicily, Sardinia and Africa (Pomp. 50; Sardinia and Africa: Cic. Fam. 1.9.9).

It is not clear what else Pompey did to alleviate the problem. Rickman suggests that Pompey sought to organise the lists of recipients, that is register the manumitted slaves, though he doubts he went so far as to conduct a district-by-district recensus - this would not happen until Julius Caesar in $46 .{ }^{356}$ Nonetheless, the fact that popular pressure succeeded in persuading Cicero, Pompey and the senate to legislate the formation of a 356 Rickman (1980: 174 f.). 
special command with fifteen legati reflects the power of the threat of rebellion.

From this study of grain distributions it is clear that the senate responded to crises, following the lead of individual reformers and inspired by popular pressure, to provide subsidised food in order to maintain stability and preserve the status quo. In this way, then, the people had political power.

\section{CASE STUDY: THE RESTORATION OF TRIBUNICIA POTESTAS}

Examination of the restoration of tribunicia potestas reveals that consistent popular support was crucial. Twice in the history of the Roman Republic the tribuni plebis lost their powers. In the first instance, the tyrants of the second decemviral commission in 450 ignored the tribunes' powers. These were restored by the tribune M. Duilius in the wake of the Valerio-Horatian laws of 449 (Livy 3.55-56). The second time was the result of Sulla's reforms in 81. This time some of their powers were not restored for more than ten years. Citizens were active in both cases to restore the power of the tribunes because these men protected individual libertas and had in recent times 
introduced bills promoting popular interests (commoda). ${ }^{357}$ Analysis of these two incidents will reveal popular methods of making the collective voice heard. The people who attended contiones worked hard to see the restoration of tribunes' powers so long as they were not distracted by offers of state-subsidised grain from opponents of the restoration. ${ }^{358}$

The first time the tribunes lost their powers, the technique adopted to secure their restoration was wide-spread secession. Livy describes how the soldiers mutinied and were joined by the civilians so that the city was left deserted, save for senators and a handful of old men (3.51-52). The withdrawal was a peaceful one, and their collective will was appeased by the return of their tribunes' powers to protect, specifically the restoration of the right of appeal (3.53).

\footnotetext{
357 In Sandberg's 2001 study of legislative practice, he argues that before Sulla's reform disempowered them, tribunes alone proposed rogationes to the tribal assembly. Curule magistrates did not do so until the late Republic. Curule magistrates were forced to legislate in the late Republic due to the "increasing tensions between the optimates and the populares which distinguish the Late Republic. During this political struggle legislation was a crucial weapon; if the curule magistrates were affronted with a college of hostile tribunes, they had no other choice than summoning the people themselves if they wished to enact a comitial law in a civil assembly. However, it is contended here that it was only with the reforms of Sulla that consuls and praetors were formally given the right to legislate before the tribes" (Sandberg, 2001: 147).
}

358 Marshall and Beness (1987: 363). The second tactic of the opponents of the restoration was to destroy any tribunes that emerged as agitators. 
Tribunicia potestas was seriously diluted a second time when Sulla's legislation made tribuni plebis powerless to introduce bills to the assembly (Liv. Per 89) and reined in their ius intercessionis. We know that their right to veto was limited because the tribune Opimius was prosecuted when he used his veto in violation of Sulla's law (Cic. Verr. 2.1.155). It is a little puzzling, then, that Caesar says tribunes never lost their ius intercessionis (BC 1.5.1, 1.7.3). He may be serving his own purpose in these passages, however, as his aim was to discredit the senators with whom he was then struggling by implying that they treated tribunes even worse than the notorious foe of the magistracy, Sulla. Another possibility is that Caesar misinterpreted Sulla's modification of the veto as a complete removal of the power. For it appears tribunes retained a residual right: they were able to use their veto to intervene if the rights of an individual were at stake, as Cicero records that Sulla did not deprive them of their ius auxili ferendi (Cic. Leg. 3.22).

While Sulla retained this one ius crucial to the protection of popular libertas, he did away with another: the right of a tribune to stand for further office (App. BC 1.100; Asc. 67 C, 78 C; Ps. -Ascon. 255 Stangl). This diluted popular power as it dissuaded aspiring politicians from considering the tribunate as part of their career. As we saw with C. Gracchus, the tribunate could be used to improve the material conditions of the people. Sulla's 
measure sounded the death knell for the tribunate as a rung in the ladder of the cursus honorum. At first sight it appears Sulla made the tribunate a deadend job to prevent his opponents from harnessing popular power to use against him and the senate. As Keaveney has noted, the actions of tribunes in Sulla's lifetime had threatened the peace and stability of Rome, and the pre-eminence of the senate over other organs of state. ${ }^{359}$ A desire to suppress men who might cause him trouble may have been part of Sulla's motivation, but he may also have had a more altruistic reason. The move benefitted the state as it reduced the corruption that came with the manipulation of tribunes. Patrons had seduced tribunes with the promise of future support to attain higher office, so long as during their term in office the tribunes did the bidding of their patrons. Marius was an expert at winning tribunes over to his cause. He used the tribune Manlius Mancinus in this way as the rogator of the bill to hand command against Jugurtha over to himself (Sall. BJ 73.7). He also utilised the skills and office of Saturninus when he was tribune. ${ }^{360}$

Cicero claims Sulla introduced another restriction to the tribunate: he forbade any tribune to summon a contio, and states that Quinctius was the

\footnotetext{
${ }^{359}$ Keaveney (2005: 140).

360 See Chapter Five below for Saturninus' attempts to pass legislation for the distribution of land to Marius' veterans.
} 
first to mount the rostra (Cic. Cluent. 110). This is surely an exaggeration, however, for we find tribunes addressing the people in contionibus as early as 76 (see below). It is likely Cicero refers not to a law banning contiones, but to a brief hiatus during which tribunes feared the repercussions should they disobey one of Sulla's commands. Once Sulla was dead and buried, tribunes ignored the prohibition.

Popular pressure resulted in the gradual restoration of these powers. But not without a fight. Opponents used two tactics to prevent the restoration of tribunician powers: first, they distracted the people from political problems by emphasising economic problems, namely food shortages, then solving them by providing state-subsidised grain distributions. ${ }^{361}$ Popular agitation declined when grain distributions occurred: in 75 and 74 aediles made distributions, and in 73 the senate bit the bullet and finally reinstated grain subsidised by the state after eight years of none. The wealthy distracted the hungry with grain distributions, and it was not until Palicanus secured Pompey's support that tribunician power was restored. 362

\footnotetext{
361 Marshall and Beness (1987: 362 f.).

362 It is interesting to note that even following the restoration of tribunician powers, grain distribution remained a means of winning popular support: Crassus, for instance, not only laid on a massive public banquet on 10,000 tables, but also provided grain enough to last each man three months (Plut. Crass. 12.2).
} 
Magistrates and inhabitants of Rome used several methods to bring about reform of the tribunate. Some adopted the constitutional route and put forward bills designed to repeal the leges Corneliae, while others sought to undermine senatorial authority in order to win the popular support they needed to ensure the success of their legislation. Those senators who refused to acknowledge the existence of judicial corruption also helped hasten the restoration of the tribunes' powers. Cicero states that the demand of the populus Romanus for the restoration was really concealing their true desire for honest law courts (Verr. 1.44). While we may doubt the reliability of his claim, given that the context of his claim was the trial of Verres for corruption, there may be truth in it: the same connection between senatorial corruption in the law courts and restoration of tribunes' powers is a theme of the Pro Cluentio (see below).

M. Aemilius Lepidus, consul in 78, was the first to propose the return of tribunician powers (Sall, Hist. 1.77.14M), after originally opposing the motion earlier in his consulship (Gran. Lic. 33-35 F.). ${ }^{363}$ Lepidus' efforts to repeal Sulla's measures came to nothing, however, as he fell out with his

\footnotetext{
363 Marshall and Beness (365) accept this conclusion of Rice Holmes (The Roman Republic and the Founder of the Empire, Oxford 1923, Vol. I, 367 f.). Sallust and Licinianus are the sources, but contradictory. Sallust has L. Marcius Philippus say that Lepidus demanded restoration of tribunician powers (Hist. 1.77.14M; cf. 1.73 M) in his speech in response to Lepidus' demand for a second consulship (1.77.15). Licianus records that Lepidus opposed restoration (Gran. Lic. 33-35F).
} 
consular colleague Catulus and other Sullans, marched on Rome, was defeated, then died after fleeing to Sardinia (App. BC 1.107; Plut. Pomp. 16; Livy Per. 90).

The first tribune to attempt to restore the powers of the tribunate was Sicinius (Ps. -Asc. 189 St.). In 76 Sallust's Macer tells us that Sicinius "dared to talk about tribunician power, but had been stopped to the accompaniment of your [the plebs'] mutterings" (Sall. Hist. 3.48.8 M). The consul C. Scribonius Curio then "played the despot to the extent of ruining a guiltless tribune" (ad exitium usque insontis tribuni dominatus est, Sall. Hist. 3.48.10 M). McGushin interprets this fragment to mean that Curio destroyed the tribune politically, through some trumped-up charge, rather than physically having him assassinated. ${ }^{364}$ Sicinius disappears from the sources after his tribunate, thus illustrating the effectiveness of this tactic for those who defended the Sullan constitution: one way to negate the opposition was to eliminate them. The only other information we have on Sicinius is that he had a "coarse but hilarious wit" (homo impurus, sed admodum ridiculus, Cic. Brut. 216), which is reinforced by the anecdote provided by Cicero (ib. 217). Sicinius was also wary of Crassus, indicating he was politically savvy and so a threat to his opponents:

364 McGushin (1994: 91). 
Sicinnius [sic], who gave the greatest annoyance to the magistrates and popular leaders of his day, when asked why Crassus was the only one whom he let alone and did not worry, said that the man had hay on his horns. Now the Romans used to coil hay about the horn of an ox that gored, so that those who encountered it might be on their guard. (Plut. Crass. 7.9)

Again his wit comes through in Plutarch's account, but more than that we get a picture of his influence: he annoyed not only magistrates (such as Curio, above) but also popular leaders (demagogoi). The language is tantalisingly obscure, but may explain why Sicinius' fellow tribunes receive no mention: they did not support his antagonistic method, or perhaps his aim to restore the powers to tribunes. ${ }^{365}$

It should be noted that these instances of tribunes addressing their fellow citizens from the rostra challenge the reliability of Cicero's claim that they were forbidden under Sulla's laws to address the people in contionibus. It may well be, however, if Cicero is correct, that as the first group to challenge Sulla's prohibition, these men were perceived to have acted outside the law. Although we suggested above that Sulla passed no law actually forbidding the practice, nonetheless his ban was enough that their contiones failed to make as much impression as they might have had they enjoyed official

\footnotetext{
365 Marshall and Beness (1987: 67) suggest the pressure for reform was not consistent and note that there was no popular outcry at Sicinius' demise, only murmurings as noted in Macer's speech in Sallust (Hist. 3.48.8.M).
} 
sanction. Without the right to lawfully mount the rostra and address the people in contione, the tribune's ability to act as rogator was severely diminished. Hence the need to find a champion outside the tribunate to restore the office's power. The other possibility is that Cicero ignored the actions of Sicinius and Opimius because his focus in the Pro Cluentio was Quinctius.366

The following year it appears that the tribune Q. Opimius had learnt from his predecessor's mistakes and made sure he had both popular backing and the support of a curule magistrate, the consul C. Aurelius Cotta. Rome was in the grip of a severe food shortage to which the people reacted by chasing the consuls (Sall. Hist. 2.45M, see above). Cotta, one of these consuls, and Opimius harnessed this popular enthusiasm. A question remains, however, regarding the object of the people's zeal: did they want a return of tribunician power or food? ${ }^{367}$ In the end the people got both thanks to factional competition to win their favour. The motives of the tribune and the consul are also far from clear: the ancient sources suggest that Cotta and Opimius sought to appease the people, rather than to win back popular

\footnotetext{
366 Thus Marshall and Beness (1987: 371).

367 Marshall and Beness (1987: 368 f.)
} 
support following Hortensius' grain distribution (Cic. Verr. 2.3.215). ${ }^{368}$ According to Macer, Cotta was motivated by fear to propose his measure permitting tribunes to stand for further office (Sall. Hist. 3.48.8M). PseudoAsconius makes no mention of Cotta and gives sole responsibility to Opimius, obviously an oversight (255 St.). More recent historians offer varied interpretations. Syme maintains that "Cotta spoke to deprecate illfeeling and conciliate popular favour, not to support or thwart any law", while Seager suggests Cotta's aim was to gain popularity for his brother who stood for the consulship of $74 . .^{369}$

Whatever the motive behind the lex Aurelia, the law roused much popular enthusiasm and not a little disapproval amongst the nobiles (Asc. $66 \mathrm{C}$ ). The reformers may have won over the people, but they had further alienated the oligarchy. As a result, both Cotta and Opimius suffered a backlash: in 74 the senate revoked some of Cotta's laws which dealt with trivial matters (according to Cicero it was Cotta himself who proposed this: Asc. 67C), and charged Opimius with inappropriate use of the veto (Cic. Verr. 2.1.155-157). If Sallust correctly captures the spirit of the moment, then the Aurelian law for partial restoration of tribune's prestige (Asc. 78C), if not power, was a

\footnotetext{
368 Keaveney (1982: 58) believes Cotta sought to appease the people as he was unnerved by the their pursuing him and as a result "cracked".

369 Syme (1964: 200); Seager (1994: 211)
} 
sop to the people to pacify their discontent in hard times, with war abroad (Sertorius was threatening the senate from Spain) and famine at home. For Sallust has Cotta deliver a speech begging the people to "endure adversity and look to the interests of the commonwealth" (Sall. Hist. 2.47M). The theme of the speech is compromise for the sake of the Republic, a theme reflected in the measures of both Hortensius and his Sullan supporters, and the tribune and his consular patron.

An important step had been made in 75 , but tribunes still lacked their essential powers: ius intercessionis and the ability to summon the concilium plebis. That is, they were still unable to propose bills. L. Quinctius was the next to try his hand at restoration of powers (Ps. -Asc. 189 St.). ${ }^{370}$ In 74 he made sure he had popular support by successfully prosecuting a judge for bribing his jury, corruption in the law courts being a popular issue in the 70s. ${ }^{371}$ But in the end he made little progress other than building up momentum for those who followed; the consul Lucullus stymied his efforts at reform.

\footnotetext{
${ }^{370}$ In another strange omission, Pseudo-Asconius fails to mention Opimius and Macer in this list of tribunes who worked to restore tribunicia potestas.

371 Marshall and Beness (1987: 371) advance a similar theory.
} 
The multitudo did enjoy some success in combination with their champion, Quinctius. Cicero tells us that Quinctius was a homo maxime popularis who had his finger on the pulse of those who frequented the Forum (qui omnes rumorum et contionum ventos collegere consuesset). It is implied that he gathered information from these citizens. From the point of view of the populus, then, the Forum was the place to go to voice one's opinion with a view to seeking resolution to problems. With information gathered in this way, Quinctius decided that the senatorial courts had such a bad reputation that he could use this to his own advantage. And so he accused the jurors of being bribed during Oppianicus' trial in 74 (Cluent. 77) and alleged that the president of the court (iudex quaestionis), Junius, failed to take an official oath and did not fill a vacancy among the jurors (ib. $89 \mathrm{ff}$.). The bad reputation of certain jurors combined with the authority of Quinctius' office (Quinctius was homo cum summa potestate) and his ability to kindle the passions of the multitudo to stimulate such a public outcry (clamor) that Junius was removed not only from his office (de foro) but even de civitate (79). From the case of Quinctius it is clear that the Forum was the centre of operations during this period for those who wanted reform, whether they were members of the multitudo or the senatorial order. It also highlights the reciprocal effectiveness of an articulate orator and a stroppy crowd. Cicero compares his own silent audience in 66 to the raucous crowd Quinctius addressed in 74: 
The accuser was a tribune of the plebs, whether on the platform or before the people, a tribune still (idem in contionibus, idem ad subsellia); and he not only came into court straight from his contio but even brought it with him. The Aurelian steps yonder - they were new then - might have been built to serve as an auditorium for the case: and when the accuser had filled them with an excited crowd (concitatis hominibus), there was no possibility of speaking for the accused; nor even of rising to speak. (Cluent. 93)

While it is clear from this passage that Cicero thinks little of Quinctius' demogogic techniques ${ }^{372}$ (not to mention his mores et adrogantiam, 111), there is an inescapable hint of grudging admiration for his oratorical skills (habetur una atque altera contio vehemens et gravis, 77). Nonetheless, despite Cicero's shared interest in the crusade to clean up the juries, there is no denying that Cicero's denunciation of Quinctius is thorough. He even goes so far as to exaggerate the effect of his departure from public life, claiming that the next year things returned to normal (Cluent. 103), which is unlikely given the food shortages attested to in $73 .{ }^{373}$

Quinctius' efforts, however, were not all successful. As in the previous year, attempts were made by the oligarchy to appease the people with grain

\footnotetext{
372 Consider also his comments on the effect of an accomplished speaker on the Roman people: "From this [experience with Junius and Quinctius] it was clear that, as has often been said: as the sea, though naturally calm, becomes rough and stormy beneath a strong wind, so is it with the populus Romanus; peaceable enough when left to themselves, the speech of a demagogue can rouse them like a furious gale" (sua sponte esse placatum, hominum seditiosorum vocibus ut violentissimis tempestatibus concitari, 138).

373 See below on the lex Cassia-Terentia.
} 
distributions. Although there is no clear indication of which faction he favoured, the examples of Hortensius in 75 and the lex Terentia-Cassia in 73 would suggest that $M$. Seius was on the side of the Sullan aristocracy. Again they sought to win over popular support from the reformers by encouraging Seius, an aedile, to fill the people's bellies (Cic. Off. 2.58; cf. Pliny NH. 15.2 for Seius regulating the price of olive oil). His distribution of grain at one as per modius gained him such popularity that statues of him were erected on the Capitoline and Palatine, and, upon his death, his body was borne on the shoulders of the populace to his cremation (Pliny NH 18.16).

Like Sicinius before him, Quinctius' efforts inspired the intervention of a member of the opposing faction. When Macer provides the bare outline of the fates of his predecessors, he laments Curio's destruction of Sicinius, and the animosity with which Lucullus moved against Quinctius (Sall. Hist. 3.48.11 M). Similarly Plutarch notes Lucullus' role in allaying Quinctius' ambition, although his tone resembles as much that of the tribune's opponents as Sallust's does the reforming tribunes: the consul applied pressure to the tribune both privately and in public to change his mind, and is praised by Plutarch for dealing with a potentially dangerous situation wisely (Plut. Luc. 5.4). Lucullus failed to completely ruin Quinctius, however. We hear of the erstwhile tribune securing the praetorship in 68 
and making life difficult for Lucullus by proposing successors to Lucullus' command against Mithridates (Plut. Luc. 33.5).

Macer was the penultimate tribune to take on the establishment in an effort to return tribunes to their former position and power. The survival of a fragment of Sallust's Historiae containing a speech purportedly made by Macer offers mixed blessings: on the one hand it is the only extant speech of a tribune from the 70s, but on the other it is impossible to tell how much is Sallustian invention. Syme suggests that Sallust may have had access to tribunician harangues from earlier times contained in Macer's historical work, along with tradition, his imagination, and the recollections of old men. ${ }^{374}$ Assuming Sallust would not have dared stray too far from the truth, especially given the existence of people who had witnessed the event, then Macer's speech offers an invaluable insight into the methods of a tribune. He gained popular support by denouncing his opponents as a factio noxiorum $(3.48 .3 \mathrm{M})$, and proceeded to expatiate on the theme of corruption in the law courts and senatorial misrule. He did not, however, counsel violence (3.48.17M); rather he exhorted the people to stop talking and take action:

374 Syme (1964: 207). 
"Quid censes igitur?" aliquis uostrum subiecerit. Primum omnium, omittendum morem hunc quem agitis, impigrae linguae, animi ignaui, non ultra contionis locum memores libertatis; deinde - ne uos ad uirilia illa uocem, quo tribunos plebei, modo patricium magistratum, libera ab auctoribus patriciis suffragia maiores uostri parauere - cum uis omnis, Quirites, in uobis sit et quae iussa nunc pro aliis toleratis, pro uobis agere aut non agere certe possitis, Iouem aut alium quem deum consultorem expectatis? Magna illa consulum imperia et patrum decreta uos exsequendo rata efficitis, Quirites; ultroque licentiam in uos auctum atque adiutum properatis. (3.48.14-16M)

The Quirites should exercise their rights and not vote for those who profit at the expense of the people. As Marshall and Benness note, "there was still the need in 73 to secure more consistent popular enthusiasm for tribunician reform." 375

The battle to win the hearts of the Roman people once more turned to their stomachs. The consuls passed a food bill, which Macer viewed with distrust, a bribe to purchase the citizens' freedom at five measures, no more than prison rations $(3.48 .19 \mathrm{M}) .{ }^{376}$ That M. Terentius Varro Lucullus was acting to undermine the tribune's efforts is reinforced by Cicero's judgement that the consul was inimicus tribuniciae potestatis (Asc. 79C).

\footnotetext{
375 Marshall and Beness (1987: 373 f.).

376 Cicero records it was Verres' responsibility to purchase grain in Sicily "ex senatus consulto et ex lege Terentia et Cassia" (Verr. 2.3.163). See also Cic. Verr. 2.3.173 and 5.52 on Verres' duty according to the lex Terentia et Cassia.
} 
The tribune M. Lollius Palicanus finally secured Pompey's support (Ps.-Asc. 189 St.). Palicanus managed to have Pompey address a contio summoned by the tribune (Cic. Verr. 1. 45). It is a mystery how he did it, especially as Sallust has a low opinion of him. He was of humble origin and not eloquent but loquacious - the secret to gaining Pompey's backing may have been their shared birthplace, Picenum (Hist. 4.43M). ${ }^{377}$ Supported by the equestrian order, the urban plebs and "omnes qui favent tribuniciae potestati" (Ps.-Asc. 220 St.), Pompey and Crassus restored tribunicia potestas (Ps.-Asc. 189 St., Livy, Per. 96). Cicero defends Pompey's role in the restoration against Quintus' subtle (staged) attack (Leg. 3.22-26). He asserts that Pompey was right to back the reform as the potestas was essential to the civitas since the power so eagerly sought by the people could not easily be dispensed with now they knew what it was. Cicero concludes his argument in defence of the tribunate by claiming that it was "the duty of a wise citizen, in dealing with an institution not evil in itself and so dear to the people that it could not be resisted, not to abandon its defence to a popular leader, which would have had evil consequences" (Leg. 3.26). He does not count Pompey a popularis! And yet Cicero himself provides evidence of Pompey's populist method. To secure popular support for the restoration of power to the tribunate, Pompey made it the subject of his first contio as

377 Wiseman (1971: 237 f.). 
consul-elect in 71. The people cheered him when he announced his intention to restore powers: "his words elicited a murmuring noise (strepitus) of grateful approval from the assembly". Cicero, however, then slips into rhetorical mode and adds that the response from the populus Romanus was much louder (maximus clamor) for his criticism of senatorial governors and jurors (Verr. $1.44 \mathrm{f}$.), for it is a theme of this speech that corruption in the provinces and law courts must be addressed. It is possible, then, that Cicero is underrepresenting the popularity of Pompey's proposal to make his point.

In little over a decade, then, popular pressure resulted in the restoration of tribunician power by convincing Pompey that the popular support derived from this action would help secure his position, and election to the consulship. The evidence of Appian and Plutarch reinforces that of Cicero above: Pompey appealed to popular sentiment by promising the restoration of tribunician powers, though the chronology of these two sources disagrees with that of Cicero, who ought to be preferred as he is a primary source: Appian and Plutarch place his announcement before his election, suggesting it was part of Pompey's election platform (App. BC 1.121; Plut. Pomp. 21.35). ${ }^{378}$ Plutarch emphasises that by passing this measure Pompey had chosen

378 This chronological issue has been noted by Marshall and Beness (1987: 375). 
the best way to thank the people for the favour they had shown him - and that had someone else beaten him to it he could not have found a better means of showing his gratitude. Military glory was not enough on its own to win over the urban plebs, whose support he needed to compete with the more established nobiles and their amici and clientes. Conservative efforts to distract the hungry by bribing them with food delayed the result, but in the end Macer and Palicanus won the support of the populist Pompey.

\section{CASE STUDY: DEBT RELIEF}

Debt relief had long been a burning issue in the respublica. From the opening years of the Republic citizens had been contending with the senate to reduce the burden of debt bondage and the arbitrary mistreatment of debtors by creditors: Livy records desire for debt reform was so great that it inspired the first secessio plebis (2.23-30). ${ }^{379}$ Not everyone, however, agrees with Livy. Forsythe, for example, claims it is illogical to explain the creation of tribunician ius auxilii in response to the debt crisis when it is obvious from the Twelve Tables that tribunes could not intervene to save debtors. ${ }^{380}$ But is Forsythe here not guilty of chronological compression? The Twelve

\footnotetext{
${ }^{379}$ For analysis of events in 495-494 see Chapter Two.

380 Forsythe (2005: 173).
} 
Tables date to 451-450, whereas this first secession took place in 494 . The codification reflects the laws of a different generation to that of the first generation of the Republic. As noted above, the effect of the Twelve Tables was to regulate the punishment of defaulting debtors, not to do away with the institution of nexum and the benefits that came with it, viz. the supply of dependent labourers to wealthy owners of landed estates.

There was a major debt crisis in the early fourth century, brought on by wars with Latins and other neighbours, plus expensive building projects. The situation was so dire that Manlius Capitolinus, the erstwhile saviour of Rome when the Gauls attacked, lost his life in a bid to provide a cure for his countrymen's indebtedness. According to Livy, Capitolinus was executed for trying to protect debtors by discharging their debt from his own personal fortune. Livy tells us he was the first patrician to intercede in this fashion and "turn demagogue" (popularis factus, Livy 6.11.7). ${ }^{381}$ Although he is critical of Manlius' motives, Livy cannot help but acknowledge that the problem existed: freemen were terrified of the thought of chains and imprisonment (6.11.8).

381 Oakley (1997: ad loc) reminds us that Livy has forgotten earlier describing Publicola as popularis in Book 2. 
Manlius' technique for rousing popular support reveals a politician who used, along with good old fasioned bribery, the passion of another man to elicit a positive response. Livy says Manlius first won the people over with speeches and deeds that appeared popularia but were in truth tumultuosa (Livy, 6.14.2). The historian maintains the image of Manlius the demagogue. By public display of generosity, he paid off the debt of a condemned centurion about to be led away to bondage and so set the old soldier free. As a result he was hailed as parens plebis Romanae (6.14.3-6). ${ }^{382} \mathrm{He}$ had the support not only of the plebs, but also a band of retainers, in the late Republican fashion (caterva sua, 6.14.3). By this point, the crowd was tumultuosa, due in part to the centurion's scars and tales of sacrifice (6.14.6). The centurion specifically placed the blame for his state of penury on usury, as interest piled up on his loan during his absence from home while fighting and then while rebuilding his house (6.14.7). He further excited the plebs by praising Manlius and promising to devote what remained of his strength, life and blood to him (6.14.8). Once the centurion had warmed the crowd up for him, Manlius stepped in and offered the farm which formed the main part of his fortune to the plebs to save anyone else from being condemned and led off into slavery. And so he ensured that, as Livy put it, "per omne fas ac nefas secuturi vindicem libertatis viderentur" (6.14.9f.). Livy is torn

\footnotetext{
382 Oakley (1997: ad loc.) and Forsythe (2005: 261) suggest this is a doublet of the centurion
} anecdote told at 2.23.1-8 and Dion. Hal. 6.26.1-2 (analysed above). 
between terming him a tyrant on the one hand, and a champion of popular liberty on the other, and in so doing unwittingly concedes that Rome had a serious debt problem.

Manlius had yet another means of eliciting popular support in addition to promising to address the problem of debt relief via speeches given in the Forum. He also delivered sermones at home in the style of a contio (Livy, 6.14.11, 18.3 and 19.1). Here Livy dips into the pool of seditious stereotypes: the holding of contiones at home is a Catilinarian motif, 383 and so increases the sense of conspiracy. But then Livy changes tack and addresses the issue of senatorial corruption, thus balancing his criticism of Manlius' demagoguery with a negative portrayal of Rome's ruling elite. Manlius' sermones were full of allegations levelled at the patres: if they used the Gallic gold they had stashed away for themselves, they could clear the plebs of debt (6.14.11). The senators took fright and summoned the dictator, A. Cornelius Cossus, from the army. Cossus first gave a speech in the curia to make sure he had sufficient senatorial support to take on Manlius and the plebs, then he entered the Comitium surrounded by a multitudo of his supporters, ${ }^{384}$ before he sent for Manlius, who arrived with a great train of

\footnotetext{
383 Oakley (1997: ad loc); Kraus (1994: ad loc).

384 Kraus (1994: ad loc) notes that multitudo can mean gang, citing Lintott (1999:a 61). See how Cicero uses the term in this way when he asks Atticus to gather a multitudo to help secure his recall (Att. 3.23.5).
} 
his own followers from amongst the plebs (agmine ingenti). Manlius convinced them to accompany him by announcing that the time had arrived for the contest (certamen) with the senators (Livy, 6.15.1-4). Cossus called Manlius' bluff and offered him the chance to get the gold off those who had it, and, if he failed, it would prove that he was a liar and the stolen gold did not exist. But Manlius was not to be outdone. He replied that the dictator had been appointed to attack himself and the plebs, not the Volsci, Latins and Hernici (6.15.5ff.). When Manlius refused to produce the gold, Cossus had him arrested. So great was his popularity that magna pars plebis put on mourning and multi mortales let their beards grow as a sign of mourning $(6.16 .1-4)$

The response to Manlius' imprisonment offers insight into the role of rumour in spreading news and informing the people of Rome of incidents. ${ }^{385}$ It was like communicating news by "Chinese Whispers," where opinions and judgements adhere to the original information and transform it into something new. Along with public oratory, rumour was the main means of communication in Roman politics. But why does Livy include rumour in this passage? One commentator has suggested that Livy 
uses this technique when he wants to claim no responsibility for the opinion contained in the rumour. ${ }^{386}$

In the case of Manlius, we have already seen the effect of speeches; now it is the turn of rumour: the plebs grew restive following the dictator's defeat of the Volsci, because there were rumours that the senate granted him a triumph not for this victory in the field, but for his victory at home over Manlius (6.16.5-6). Thus the actions of the senate brought about that which they had most feared. Had they not reacted against Manlius' well intentioned actions to relieve debt, the plebs would not have grown seditious. The senate tried to dissipate the tension by ordering two thousand citizens to establish a colony at Satricum, but the move back-fired on them when this remedy aggravated the sedition as the land parcels were considered too small, and given to too few, and came at the cost of Manlius' betrayal (6.16.6-7). Indeed, rumour made much of this betrayal of a defender of popular liberty and dwelt on the unreliability of the plebs and the fickleness of their loyalty: they had abandoned Sp. Cassius and Sp. Maelius at similar critical points in their campaigns for land and food distributions (6.17.1-5).

386 Kraus (1994: ad loc). 
Manlius' seditious activity continued into the following year with meetings of the plebs held night and day at his house so that he might discuss his plans with the leaders of the revolution (cum principibus novandarum rerum interdiu noctuque consilia agitat, 6.18.3). Livy has Manlius deliver a speech, reminding the plebs of their strength in comparison to that of their enemy, and emphasising the desire to fight is more fierce amongst those fighting for their libertas than it is amongst men who fight for dominatio. He promised to be patronus plebis. But then he made his fatal mistake: he appealed to the plebs to give him a more significant title of imperium or honos so that he might have the power to better attain their wishes (6.18.5-15). Livy created this speech to make his point: he has ceased to paint Manlius as a protector of libertas and now portrays him as an out-and-out tyrant, agitating for regnum (6.18.16). He ends his representation of Manlius' position by commenting on the lack of information in his sources on the length to which his plans had matured, which indicates that he was following an earlier tradition rather than creating a speech out of thin air in order to cast Manlius as tyrant. There existed an established tradition that traced the fall of Manlius, but not one that was sufficiently coherent or reliable to convince Livy to include material from it. ${ }^{387}$ This reluctance on the part of the ancient historian must make us wonder how reliable the account contained in Livy

387 Kraus (1994: ad loc). 
is when it comes to other aspects of Manlius' career, and indeed whether he was aiming for regnum rather than his initial stated aim of defending the freedom of the plebs.

There are undoubtedly inaccurate details in Livy. Above we noted late Republican accretions regarding his accounts of the secessions of the plebs. In the Manlian passage there is one glaring inaccuracy: the anachronistic senatus consultum ultimum (6.19.3). The first attested SCU was passed in 121 against Gaius Gracchus and his followers. ${ }^{388}$ Its presence here reinforces Manlius' connection with the late Republican politicians who were declared enemies of the state by this, the ultimate decree.389 One thing, however, is certain. M. Manlius Capitolinus caused, as Forsythe puts it, "some kind of major disturbance" in the 380s. ${ }^{390}$ The incontravertible evidence is provided by the fact that the Manlian clan forbade anyone ever have the praenomen Marcus again and this restraint was adhered to (Livy, 6.20.14). In addition, the foundation of colonies two years later suggests an effort to release pressure on social and economic tensions. ${ }^{391}$ The suppression of Manlius

\footnotetext{
388 On the SCU see Lintott (1999a: 149-174).

389 Kraus (1994 ad loc). See also Forsythe (2005: 260 f.) on Manlius' heavy resemblance to Catiline.

${ }^{390}$ Forsythe (2005: 261).

${ }^{391}$ Forsythe (2005: 262).
} 
did not get rid of the debt problem: there was further agitation on the same issue in 380 and 378, with the lot of the plebs made worse by the construction of the massive "Servian" wall, paid for by new taxes. ${ }^{392}$ Even though the detail may contain anachronisms, the sheer amount of laws dedicated to the issue of debt relief guarantee that the problem existed.

Livy's narrative of the mid-fourth century also suggests there was a debt crisis at the time - a crisis to which the plebs responded by electing men to the tribunate who would represent their interests. This was the case in 367 when again the huge load of debt threatened res novandae: "[aeris alieni] levamen mali plebes nisi suis in summo imperio locatis nullum speraret" (6.35.1). The plebs had no hope of relief unless they secured summum imperium for men from amongst their own number. They also sought to be equal to the patricians in honos et virtus (6.35.2). For this reason the plebs elected G. Licinius and L. Sextius tribunes of the plebs, men who promulgated laws aimed at redistributing patrician wealth to plebeians:

Creatique tribuni C. Licinius et L. Sextius promulgauere leges omnes aduersus opes patriciorum et pro commodis plebis: unam de aere alieno, ut deducto eo de capite quod usuris pernumeratum esset id quod superesset triennio aequis portionibus persolueretur. $(6.35 .4)^{393}$

\footnotetext{
392 Cornell (1995: 331). Livy blames building for the piling up of debts in 385 (6.11.9).

393 On the regulation of interest and the Licinio-Sextian laws in general, see Forsythe (2005: 262-267).
} 
A tremendous struggle ensued as the patres tried to prevent the passage of the laws by enlisting the support of tribunes to veto the proposals. These tribunes surrounded themselves with a guard (praesidium) of patricians and prevented the bills from being read out. But Sextius fought fire with fire and used the opposing tribunes' tactic to veto the election of curule magistrates (at this time, military tribunes rather than consuls, 6.35.6-10). Eventually, however, the reformers relented. The people of Tusculum had appealed for help from Rome to lift the seige set on them by Velitrae, and the plebs felt shame at not helping their fellow citizens, and so compelled the tribunes of the plebs to reconsider their strategy and allow the election of military tribunes (6.36).

Livy gives no detail regarding the technique used by the plebs to convince the tribunes to change their mind, but it is likely the males of military age petitioned their representatives in person, as Livy gives the impression that the tribunes were readily available for their people. Despite relenting on the election of magistrates, the plebs nonetheless resisted the levy to show they were still frustrated at the patrician refusal to allow the passage of the Licinio-Sextian laws (6.36.1-4). But the tribunes had not run out of tricks to secure their proposals' success. Re-elected for an eighth consecutive year, Licinius and Sextius were now experts at playing on popular passions (artifices iam tot annorum usu tractandi animos plebis, 6.36.10). They had 
become accomplished orators, skilled in managing their audience, skilled in persuasion. The term artifex, however, can evoke negative connotations of chicanery and, as interpreted by one commentator, Livy's choice of the word here casts doubt upon the tribunes' motives: they were more interested in their own commoda than those of the plebs (reinforced by their statements at 6.35.2-3 and 39.5-12). ${ }^{394}$ We should consider, however, the context of this passage: the object of their manipulative language here is not so much the plebs as the senate. This is borne out by their technique. They would summon leading senators before the people and ply them with questions about the measures, thus forcing the senators to expose their greed and hypocrisy (6.36.11-12). Livy's point here, then, is that the tribuni plebis were tricking the senators into revealing their corrupt activities in order to undermine the position of the patres and in so doing bolster their own.

The senate in response appointed as dictator Camillus, who delivered a harangue against the intransigent tribunes, warning them that if they tried to pass their measures in defiance of their colleagues' vetoes he would not permit vim tribuniciam to be its own undoing and would distract the plebs by making them enlist and go to war (6.38.4-8). But before Camillus could carry out his threat, he resigned his office. Livy is not sure why, although he favours the suggestion that there may have been an irregularity in the

${ }^{394}$ Kraus (1994: 285) provides as an example Cicero Verr. 2.5.183. 
dictator's election. The other possibility is that the plebs decreed that he be fined should he take any action as dictator, but Livy finds this less likely for several reasons. In the first place, such a decree was unprecedented and, in the second, as Camillus was appointed dictator the following year, he can hardly have suffered the ignominy of a fine only to return to the office once more (6.38.9-13). Plutarch makes no mention of the possibility of his resigning due to an irregularity, but assumes the tribunes had secured a plebiscite: "The tribunes, on the contrary, for their part, opposed his threats with solemn oaths that they would fine him fifty thousand silver drachmas if he did not cease trying to rob the people of its vote and its law" (Cam. 39.4). The Licinio-Sextian laws were finally passed in 367 (6.42.9).

This episode is also interesting for the fractures it reveals in the relationship between plebs and their tribunes. Kraus contends that the adversative asyndeton (plebi: ducibus plebis, 6.38.9) sets the plebeians apart from their tribunes and reflects the conventional view that they did not act independent of persuasive leadership; the crowd was "a shapeless mass that can be swayed by persuasion but is itself essentially without initiative" ${ }^{395}$ Livy reinforces this distinction between leaders and led: the plebs were most keen on the passage of the measures relating to debt and land, and would

395 Kraus (1994: 297). 
have rejected the proposal to make it compulsory that one consul be plebeian had the tribunes not insisted on tying it to the other two measures (6.39.1-2). The tension between the wealthy tribunes and poorer common folk began to show when the tribunes vented their frustration at the plebs' lack of commitment to back their reforms (6.39.8-12). Yet this works against the argument of Kraus that the plebs were under the sway of their leaders. Rather, they clearly knew what was in their interest (land distribution and debt relief), and what was not (plebeian consuls). Indeed she acknowledges the power of the people in her analysis of an earlier passage (6.38): "The present crowds, however, are neither simply spectators nor followers of a charismatic leader: their potential to exert democratic control means that their momentum, as encapsulated by the stubborn tr. pl., is unstoppable."396

The problem of members of the plebs becoming heavily indebted to creditors continued as the latter ignored the law of Twelve Tables which limited interest to a rate of one twelth (unciarium fenus). In 357 the plebs ratified a measure proposed by the tribunes M. Duillius and L. Menenius to revive the obsolete enactment. Livy does little more than record the maximum rate of interest, and even then he fails to mention the period over which it was charged, so we are left with no clue as to what event, if any,

396 Kraus (1994: 293). 
provoked the lex other than general hardship brought on by greedy creditors (Livy, 7.16.1; Tac. Ann. 6.16). ${ }^{397}$

The plebs did, however, succeed in convincing the politicians to embark upon a more serious attempt at dealing with the issue in 352 after they brought out into the open their distress at the increasing weight of usury. Livy does not explain exactly what form their dissatisfaction took, using simply the phrase curaeque privatae in certaminibus publicis erumpebant (7.21.3). Their "public contests" resulted in the appointment of five commissioners called mensarii (bankers) to hand out state loans to debtors. Livy confirms that the popular protest was successful for a huge amount of debt was cleared without either side complaining (7.21.5-8).

Five years later a further measure was passed so that the maximum rate of interest set in 357 was halved, and debtors permitted to pay one quarter of their debt, with the balance due in three annual instalments. Although this reduction in interest appears generous, the measure still left a section of the plebs suffering as paying off a quarter a year would have been a struggle for many peasants. Livy explains that the senate was more concerned with the public than private credit, but the senators did try to lighten the burden by

\footnotetext{
397 Exactly what the interest rate was is not clear as it depended on the period over which it was charged. See Oakley (1998: 177f.) for a discussion.
} 
saving the plebs from the twin evils of tributum and dilectus: no tax was collected, nor levy held (7.27.3-4). This at least offered some respite to the citizens, if not in the form of out-and-out debt relief. ${ }^{398}$ It must be noted, however, that the tributum in question was that tax paid by those not fighting to cover the expenses of those who were. ${ }^{399}$ And Livy tells us there were no wars this year (7.27.3), so the respite from payment was redundant as no payment would have been required.

It was not long before creditors were once more in the limelight: in 344 aediles prosecuted moneylenders (feneratores) and the people found them guilty, but, as to the nature of the crime Livy (7.28.9), our only source, gives no hints. Livy also records an interregnum in 344 but does not mention its cause, perhaps because he found it too boring to mention. $400 \mathrm{He}$ then tells us that the interregnum was followed, "so that that might seem to have been intended," by the election of two patrician consuls (7.28.9-10). This statement does not make sense, however, as the appointment of an interrex to resolve a disputed election would be expected after, not before, such an election, ever since one of the Licinian-Sextan laws stipulated that one

\footnotetext{
398 Oakley (1998: 263).

399 Rosenstein (2004: 54).

400 Oakley (1998: 272).
} 
consul had to be plebeian. ${ }^{401}$ I suggest that if we combine the evidence of the interrex with the prosecution of moneylenders we can propose that there was a debt crisis in Rome of such severity that elections could not be held, perhaps due to civil unrest with voters preventing or even boycotting elections. The subsequent secession only two years later, which resulted in the lex Genucia, supports this theory.

A mutiny led to the proposal of the tribune Genucius finding senatorial support. As noted above, ${ }^{402}$ soldiers stationed at Capua marched on Rome, not demanding the cancellation of interest, but good land such as that in the possession of the Capuans. Debt was, nonetheless, part of the issue: they did not want to return to Rome and her harsh debt laws (Livy 7.38-42; Dion. Hal. 15.3.5). The lex Genucia made illegal the charging of interest, although the law was seldom enforced.

The next step in ameliorating the plebs' debt burden was the ban on debt bondage, or nexum, and was achieved by direct popular pressure on the senate. $^{403}$ This was an important advance in securing and protecting the personal libertas of citizens. The incident which prompted the reform is

\footnotetext{
${ }^{401}$ Cornell, Forsythe and Oakley are silent on the matter.

402 See Chapter Three.

${ }^{403}$ For a thorough treatment of the topic see Oakley (1998: 688-694).
} 
unusual: a libidinous fenerator tried to seduce a handsome youth who had been handed over as nexus on account of his father's debt.404 An ingens vis hominum rushed into the Forum, and then rushed in a column (agmine facto) to the Curia, forcing the senate to be convened. The consuls were ordered to carry a proposal to the people that no debtors should be held in chains or in the stocks, and that only a person's goods, not his body, should be liable for money lent. Livy dates this lex Poetelia to 326 (Livy 8.28; cf. Cic. Rep. 2.59, Dion. Hal. 16.5.1-3, Val. Max. 6.1.9).

Debt provided the stimulus for the final secession of the plebs in 287 that gave rise to the lex Hortensia (Livy Per. 11; Plin. NH 16.37). ${ }^{405}$ In the end, however, the law itself included no debt relief because those drafting the bill considered the matter too inflammatory; the fear was that a clause on debt relief would scuttle the chance for reform in other areas. ${ }^{406}$ The pattern we saw above with the Licinio-Sextian rogations was continued in this instance also, with the Hortensian law addressing more the commoda of the elite plebeians than those of the commoners: the lex was a disappointment to the plebs as it opened no floodgate of radical popular legislation but was

\footnotetext{
404 Livy may be picking up on the theme of reform resulting from father of violated progeny. Compare the case of Verginia, whose enslavement inspired the second secession and the dissolution of the second decemvirate (Livy 3.44-55).

405 On the lex Hortensia see Chapter Three and Cornell (1995: 378-380).

${ }^{406}$ Hölkeskamp (2004b: 49-83, esp. 78-81).
} 
instead a triumph of the patricio-plebeian oligarchy because they kept in their hands the means of legislation while getting rid of the last vestiges of patrician obstruction. ${ }^{407}$

There is little evidence of pressure for debt relief between 287 and 89 . This may be due to the distraction of the wars against Pyrrhus and the Carthaginians. Another reason: the dearth of sources once Livy's coverage is lost between 292 and 219, then again from the end of 167. A third possibility is that there was less need for debt relief, with the cost to assidui and aristocracy of the two Punic Wars offset by the financial gains of imperial expansion.

After the Social War, however, a credit crisis gripped the state. A. Sempronius Asellio, the praetor urbanus in 89 BC, upset equestrian creditors when he proposed that the lex Genucia be followed so that no interest was charged on loans. Creditors argued that they would follow custom, not some obsolete law. Then they ripped him to pieces. He was interrupted while offering sacrifice to Castor and Pollux, pursued out of the Forum and into a tabernula where an unnamed assailant slit his throat. Even though the senate offered a reward, the moneylenders engineered a cover-up and the

${ }^{407}$ Cornell (1995: 344), citing with favour Hölkescamp and Eder. 
perpetrator was never found (Livy Per. 74; App. BC 1.54; Val. Max. 9.7.4). ${ }^{408}$ Badian observes that the way he was chased and then murdered reveals premeditation and deep hatred, which he believes cannot be understood without looking into Asellio's past, and concludes that Asellio was at the heart of a movement aiming to recapture the loyalty of the indebted plebs, and had probably used this promise as a platform for his campaign for the praetorship. ${ }^{409}$ This incident reveals the importance of popular support to the senate since the senators were prepared to take on a powerful equestrian faction in order to win the people over, and also how powerful this particular faction of equestrians was given that there must have been witnesses to the murder of the praetor, and yet they managed to stifle any information from leaking out.

Sulla as consul in 88 tried to deal with the serious economic crisis brought on the by the Social War and exacerbated by Mithridates' occupying Asia Minor and so preventing the collection of tax revenue. The details are fragmentary, but from what remains it appears that Sulla passed a bill which first remitted one tenth of the debt, then applied maximum interest

\footnotetext{
408 The two main sources, Appian and Valerius Maximus, agree in most aspects of this incident, differing only in details, e.g. Appian records Asellio had his throat cut, Val. Max. that he was ripped to shreds. For interpretations of the event, see Badian (1969: 475-481) and Brennan (2000: 443).

409 Badian (1969: 478-480).
} 
payments on the principal, reviving the law of 357: “Unciaria lex appellari coepta est, quam L. Sulla et Q. Pompeius Rufus tulerunt, qua sanctum est, ut debitores decimam partem..." (Fest. 516L). Sulla's measure was a compromise to keep both debtors and creditors content by charging a relatively modest rate of interest. He needed to avoid stirring up any extra resentment at home while he was abroad dealing with Mithridates, yet at the same time he needed to bring relief to those wealthy Romans who had lost property to the enemy during the Social War, and income to the state treasury which had been seriously depleted during this period. ${ }^{410}$

Despite the several efforts to deal with the crisis, it continued. Within a couple of years, Valerius, the suffect-consul of 86 , tabled a bill to deal with crippling debt. ${ }^{411}$ Sallust says the magnitude of the debt was so great that "silver was paid off in bronze" (argentum aere solutum est, Cat. 33.2). ${ }^{412}$ This lex Valeria allowed those in debt to settle for $25 \%$ of the principal (Vell. Pat. 2.23.2).

${ }^{410}$ Keaveney (2005: 56).

${ }^{411}$ Badian (1962b: 56).

412 Ramsey (2007:152) says debtors had to pay one quarter of the remaining principal, and seeing as one silver sesterce was worth four bronze asses, the law required the payment of one bronze as for every sesterce owed. 
Valerius' measure remitting three quarters of all debt was a very generous act, yet there is no record of any popular activity which prompted the action, nor of any response. There is, however, in the next case. During the praetorship of M. Marius Gratidianus in 85, the tribunes summoned the praetors together to draft an edict on the standard of value for the currency. The group had agreed to publish it together, but Marius did it himself on the sly and so alone received the credit for the measure. He was heroised for his deed: "nemo umquam multitudini fuit carior" (Cic. Off. 3.80). ${ }^{413}$ Cicero comments further that Marius' publication of the edict "excitabat fluctus in simpulo," a reference to its reception in their hometown of Arpinum (Leg. 3.36). Marius was clearly aware of the popular support to be gained from such a reform, risking even the rebuke of his colleagues and the tribunes to go solo and publish the decree.

The sources are quiet on the topic of debt for more than twenty years. We know of no further agitation for relief until the most infamous of all. In 63, Catiline took on the majority of the senate in an effort to achieve the twin aims of cancellation of debt (novae tabulae) and increased dignitas for himself and other members of the elite who had suffered political humiliation. ${ }^{414}$

413 Badian (1969: 478).

414 For his indignant response to repeated election defeats (insulted dignitas, wasted effort, and voters electing unworthy men instead of him, Sall. Cat. 35.3-4) being that of a normal 
The frustrated senator used oratory to encourage popular participation in the movement and to unite the disparate groups who sought debt relief. At the same time Catiline and his lieutenants organised an armed rebellion to secure the consulship for Catiline. Once he had secured that office, he planned to cancel debt. His plans, however, never came to fruition as he died on the battlefield in the first armed insurrection since the days of Lepidus and Sertorius. ${ }^{415}$

A financial crash motivated Catiline's movement for debt relief. Yet, some argue otherwise. Scullard, for instance, makes the common mistake of confusing the two aims of debt relief and enhanced dignitas. He contends that Catiline needed a cause to win more supporters in order to secure election to the consulship, and that a promise to cancel all debts

would appeal to all the discontented in Italy (e.g. any of Sulla's veterans that had failed as farmers) and especially to many spendthrift nobles, like Catiline himself, who were in debt, but it would antagonize the bulk of the Senate, the Equites, and the small shopkeepers and workers. ${ }^{416}$

Roman aristocrat, see Gruen (1974: 418). Catiline wanted to be consul, not dictator (Sall. Cat. 20.17)

415 See Yavetz (1963: 498) for speculation on what Catiline might have done had he secured the consulship.

416 Scullard (1959: 108). 
Scullard discredits Catiline's motives from the start by alleging that he acted out of self-interest because he himself was in debt. Cicero too suggests that Catiline was short of funds in comments in a defence speech delivered in 63. Catiline announced in contione domestica that no loyal defender of the miseri could be found except for one that was miser himself (Pro Mur. 50). In this context, miser has been translated as "poor". Sallust shares the judgement, claiming Catiline's lack of assets wound up his defiant spirit (Cat. 5.7; cf. Florus 2.12.1). Yet Catiline asserted in his letter to Q. Catulus that he could have paid off his own debt (Sall. Cat. 35.3) and his credit was good enough to borrow money after his election loss to Cicero and Antonius (Sall. Cat. 24.2). It is not clear why Scullard has included shopkeepers and workers in the group of those who would oppose cancellation of debt. Senators and equites yes: money they had loaned would not be repaid. But the small shopkeepers and workers had everything to gain. We have evidence from the time of Caesar that rent was a real burden on those who lived in the city: Caesar waived rent payments for one year (Dio 42.51.1). Therefore, these poor people would have benefitted had the tables been wiped clean as surely they had borrowed money to cover their rent. Perhaps Scullard refers to their suffering should any violence erupt in the city itself, a point Gruen validates. ${ }^{417}$

417 Gruen (1974: 430 f.) with Sall. Cat. 48.1-2: the support of the plebs withered up once it got out that there were plans afoot to torch the city, for they feared they would lose the tools 
What is more, the evidence suggests that there was a real need for reform of the financial system. After heavy Italian investment in Asia, Mithridates overran the province, murdering Italian businessmen and taking hold of Roman property. Cicero records the impact on credit as men failed to make payments: "nam tum, cum in Asia res magnas permulti amiserunt, scimus Romae solutione impedita fidem concidisse" (Imp. Pomp. 19). ${ }^{418}$ Once Pompey had defeated Mithridates, money began to flow back into Asia, but to the detriment of those who owed money to creditors in Italy keen to retrieve their capital and invest it in the province. ${ }^{419}$ Money was in such short supply in 63 that even the state treasury was bare, compelling the senate to forbid the export of gold (Cic. Vat. 11f.; Flacc. 67). Therefore, when Catiline campaigned for the consulship in 64 on a platform of debt cancellation, he was not creating a straw man for the sake of gaining popularity. There was a legitimate problem which the senate had failed to solve. Nor was he serving his own interests as a debtor; for, as noted above, he was not in financial difficulty. Yet, because we cannot be sure of his motive due to the bias of our sources, we need to consider all options. So, while he may have been able to manage his own debt comfortably, the

\footnotetext{
they needed to survive in the conflagration.

418 See Jonkers (1959: 34f.).

419 Gruen (1974: 426 f.).
} 
cancellation of debt would nonetheless have been a happy secondary result for him.

Yavetz offers a concise overview of the modern interpretations of Catiline's motives. ${ }^{420}$ He suggests that indebted aristocrats and plebs made an alliance against the money lending equites and for the first time tried to cancel debt by armed force rather than legislation. ${ }^{421}$ Catiline lost the support of a significant sector of the urban plebs when the tabernarii decided a one off cancellation of debts was not worth the dangers involved in armed revolt. ${ }^{422}$ Others were put off by the threat of fire in the city, a threat greatly exaggerated by Cicero, and fear of a repeat of the suffering caused by civil disturbances twenty years earlier (Cic. Cat. 3. 24f.; Sall. Cat. 43, 48.1-2; Dio 37.4; Plut Cic. 18; Cat. Min. 22; App. BC 2.3).

Catiline's professed aim was noble: he announced in a speech delivered at his house before the elections in 64 that he sought the consulship to ensure justice: a fairer distribution of wealth and dignitas (Sall. Cat. 20). The first goal would have been difficult enough to achieve in a state such as Rome where, for instance, soldiers struggled to get their fair share of booty from

\footnotetext{
420 Yavetz (1963: 485-487).

421 Yavetz (1963: 498).

422 Yavetz (1963: 497).
} 
greedy commanders and landless fought to gain access to land illegally occupied by the rich. ${ }^{423}$ As for dignitas, in the competitive environment of Roman politics, the tradition of sharing dignitas existed in theory. Yet in practice we often see laws passed in an effort to curb certain families or factions from domination of office-holding. 424

When Catiline lost the election, however, his aims changed as his frustrated dignitas boiled over. He borrowed money and sent it to Manlius in Etruria to help the ex-centurion rally troops from amongst the veterans who populated the area. Men were also sent to Picenum, Apulia, and other strategically favourable spots for the same purpose (Sall. Cat. 27.1). Others still visited Gaul (ib. 42.1f.). Manlius composed a letter containing similar aims: libertas and legal protection from the harsh judgments of praetors regarding debt (Sall. Cat. 33.4-5). Of course the military man did not seek dignitas as that is an aristocratic preoccupation, but libertas for Roman citizens outside the elite contains the same idea of fair treatment and respect. Gruen warns against accepting the propaganda from both sides:

${ }^{423}$ E.g. M. Postumius Regillensis was stoned to death by his own soldiers in 414 because he deprived them of booty and acted with ruthless cruelty (Livy 4.49-50). L Aemilius Paullus became unpopular with is troops when he refused to distribute sufficient booty to them, although in this case Livy (45.35.5-7) accuses the milites of avarice, not their commander. Marius was never so stingy, aware as he was of the mercenary nature of his legionaries. The classic case of land redistribution is that set up by Ti. Gracchus' lex agraria which established a commission to oversee the distribution of public land held in excess of the legal maximum stipulated by the Licinio-Sextian laws of 367 .

${ }^{424}$ E.g. the lex Villia Annalis of 180 B.C., reinvigorated by Sulla. 
naturally the Catilinarians present altruistic motives, while concealing their selfish aims of revenge and increasing their own prestige. By the same token, there is a long history of any lower class discontent being portrayed as stemming from vicious criminals and degenerates. 425

The action of raising an army appears more of a threat to the state than it might have been. Catiline was not the first to use an army to protect his dignitas, nor would he be the last. But his failure to win the consulship meant he lacked the backing of an army in the style of Sulla, Cinna or Lepidus, and this resulted in his having to raise one from scratch. ${ }^{426}$ Catiline's lack of the official sanction which comes with holding a curule office may have contributed to his failure to maintain the support of the urban plebs.

His supporters were desperate for relief from debt and protection of their libertas and dignitas: poor urban plebs who had borrowed to meet rent payments, senators and equestrians who had been humbled in their political aspirations, local magnates from colonies and municipalities, and rural plebs and veterans struggling to make ends meet in the sometimes alien

\footnotetext{
425 Gruen (1974: 423). On the negative stereotype of "mob" or "rabble" pinned to any popular disturbance, see Rudé (1964: 7f., 198-208).

${ }^{426}$ Keaveney (2007: 101 f.).
} 
world of farming. ${ }^{427}$ This movement was not spontaneous but had been simmering in various areas for different reasons and for some time. The rebellion burst into the open once its leaders united.

In Rome, the organisers were the praetor P. Cornelius Lentulus Sura and C. Cornelius Cethegus. According to Cicero (Cat. 4.17), they used a pimp to rush around the tabernae to recruit the poor and naïve (egentes atque imperiti) but could find no one desperate enough to risk losing his workplace and bed, so reliant were the majority of tabernarii on peace for their livelihood (quaestus). From this description it sounds like the owners of shops were the target, and perhaps also their customers who could not have avoided overhearing the invitation. Regarding the choice of a leno, we must, of course, bear in mind that the orator was trying to discredit Catiline in front of a popular audience in the speech from which this evidence originates, and so was trying to associate him with the undesirable elements of society. In order for Cicero to persuade his audience, he could not associate anyone in that audience with Catiline and his movement, as allegations of fraternity with criminals and pimps was a sure fire way to lose friends, not influence people.

${ }^{427}$ As noted in Chapter Three above. Oddly, Vanderbroeck (1987: 231 f.) fails to analyse Catiline's supporters outside of Rome, focusing only on the actions of those in the city. 
Indeed Sallust gives more detail of Lentulus' activities. The praetor used freedmen and clients to galvanise the artisans and tradesmen on the streets to attack Cicero, and others he sent to elicit the support of duces multitudinum "who for a price had been accustomed to ravage the commonwealth" (partim exquirebant duces multitudinum qui pretio rem publicam vexare soliti erant, Cat. 50.1). These leaders of the common people are characterised by one commentator as trouble-making "leaders of armed street gangs", their actions an "evil" which the senate sought to overcome by outlawing collegia in 64.428 The plural multitudinum is unusual, and where the singular is usually understood to mean "crowd", the plural becomes "mobs". ${ }^{429}$ I am not convinced that the context requires such a derogative interpretation. Sallust could just as easily be referring to "leaders of crowds or commoners" rather than leaders of gangs. Sallust might have used duces operarum if he intended to categorise them as heading gangs. Rather, these were the men who ran the neighbourhood colleges, the same

${ }^{428}$ Ramsey (2007: 190).

429 OLD "multitudo" $5 \mathrm{~b}$ gives this translation. The only other occurrence of multitudinum is in Apuleius "In hac non suo nomine de statu et de commodis ciuitatis requirens originis eius principia et fundamenta disponit, sed eo tendit quemadmodum ciuilis gubernator, eiusmodi locum conuentusque multitudinum nactus, iuxta naturam praesentium rerum et conuenarum debeat facere ciuitatem plenam bonarum legum et morum bonorum (De dog. Plat. 2.26). 
men who were highly valued as influential contacts to groom by the author of the Commentariolum Petitionis. 430

Catiline had also suborned tribunes whose job it may have been to close the shops to free up supporters. In the end, though, the tribune Bestia refrained from taking any action - he was to call an assembly after Cicero's murder. Instead, Cicero found out about the plot and posted guards throughout the city and arrested Lentulus and Cethegus after a SCU was passed. Despite attempts by their slaves and freedmen to set them free with the help of artisans, Cicero had them executed. Cicero's move calmed the crowd, but their pacification was not complete until Cato proposed to increase the number of grain recipients. 431

The significance of the Catilinarian conspiracy for my study is that it reveals the lengths to which a frustrated populace will go for the sake of the protection of their libertas. Although Catiline and his supporters failed to achieve their aims, Caesar learnt from their mistakes and succeeded in lightening the debt burden through first crossing the Rubicon in defense of

430 See Comm. pet. 30: "reckon up the whole city - all the collegia, pagi, vicinitates; if you strike a friendship with the leading men from among their number, you will easily, through them, secure the masses that remain".

431 App. 2.2-6; Cic. Cat. passim, esp. 1.8, 10, 2.26, 3.5, 10, and 4.17; Diod. 40.5; Sall. Cat. passim, esp. 24.4, 26.4, 29.2, 30.7, 37.1, and 50; Plut. Cic. 10.2-11, 14-22; Dio 37.29-36; Liv. 102; Flor. 2.12 . 
his dignitas, then resorting to more legitimate means to reform the credit system. $^{432}$

One of those who has defended Catiline from his critics and contended that Catiline sought debt reform is Walter Allen, Jr. The historian argues that Catiline's actions in 63 were not a bid for power but an attempt at reform. ${ }^{433}$ Allen concludes with one final piece of evidence that Catiline sought reform - his erstwhile friend Caelius Rufus died struggling against Caesar to achieve debt reform.

Caelius proposed suspension of payments of interest during his time as praetor peregrinus in 48.434 Then, when he met stiff opposition, he came up with new measures designed to be even more enticing to potential supporters: free rent for a year and the cancellation of debts. Livy says the praetor stirred up the plebs with the hope of cancellation of debts and incited sedition in the city (Per. 111). Another theory suggests that he desired reform to solve his own indebtedness (Vell. Pat. 2.68.1-2), but we should be suspicious of this explanation as it has a distinctly Catilinarian

\footnotetext{
${ }^{432}$ Frederiksen (1966) analyses Caesar's response to the problem of debt. ${ }^{433}$ Allen (1938: 70-85).

${ }^{434}$ Caes. BC 3.20.1-22.4; Dio 42.22.1-25.3; cf. Cic. Fam. 8.17; Vell. 2.68.1-3; Quintil. Inst. Or. 6.3.25.
} 
ring to it. Caesar had illustrated the best way to go about reform: suggest boldly, act modestly. Some debt reform was good, but not too much, as that risked allegations of self-interest.

Caelius' next move was not legal. In order to start helping to settle people's debts he set himself up beside the urban praetor Trebonius whose responsibility he thus impinged upon. The motivation behind this move is not clear. It may be that he was angry with Caesar for supporting Trebonius' candidature for the plum job of urban praetor and not his own, and so sought revenge. Another possibility is that he believed Caesar's measures insufficient to address the issue of overwhelming debt and a shortage of cash with which to settle loans, so tried to stop Trebonius from dealing with debtors based on Caesar's measures. ${ }^{435}$ A third option is that he sought to compete directly with Caesar for popular support. This last suggestion would explain why Caesar had him killed: he feared competition for popular affection and the power that came with winning the support of the populus Romanus.

Caesar had undertaken a general revision of debt as dictator $49 \mathrm{BC}$. As the consul put it himself, "as credit throughout Italy was somewhat restricted

${ }^{435}$ Frederiksen (1966: 133). 
and loans were not being repaid, he decided that arbitrators should be appointed to estimate the value of real and movable property as it had been before the war, and that the creditors should be paid on that basis." (Caes. $B C$ 3.1). ${ }^{436}$ There was a shortage of coin which prevented the repayment of loans (Cic. Att. 7.18.4; 9.9.4; 10.11.2). ${ }^{437}$

A comparison of Caesar's version of Caelius' activities with those of Caelius himself and Dio reveals the extent of Caesar's bias in favour of promoting his own good image, along with that of his closest followers. Caesar claims, Caelius "causa debitorum suscepta" set up his tribunal next to the urban praetor Trebonius and promised to help anyone who wanted to "appeal about the valuation and payment of debt, as Caesar had arranged when he was in Rome". But according to a hostile Caesar, jealous to protect his own popularity, no one lodged an appeal with Caelius because his man Trebonius offered a better deal:

But through the equitable decrees and humanity of Trebonius, who was of the opinion that in this crisis law should be administered with clemency and moderation, it happened that none could be found to originate an appeal. For a man of merely ordinary spirit can make the excuse of poverty and complain either of his own difficulties or of the difficult times and set forth problems of sale, but to insist on holding onto one's possessions when one admits to owing a debt - what kind of person, what kind of cheek is that? (Caes. BC 3.20).

${ }^{436}$ See also Suet. Iul. 42.2; Plut. Caes. 37.1; App. BC. 2.48; Dio 41.37f., 42.22, 51.1 f.

437 See Carter (1993: $140 \mathrm{f}$.$) on the debt problem in this period.$ 
Thus Caesar portrays Trebonius as offering a better deal than Caelius so that anyone with half a brain would go to him and get half the principle waived. So, with no one keen to take up his offer, Caelius promulgated a law (legem promulgavit) that debtors repay their loans without interest in six annual installments (Caes. BC 3.20.5). ${ }^{438}$ Note that Caesar emphasised what he wished his audience to believe regarding Caelius' motivation: the praetor proposes the law "lest he seem to have embarked upon a disgraceful cause in vain" (ib.). Caelius' cause is turpis; he does not make the usual praetorian ruling (formula), but passes a lex. It seems unlikely that Caesar mistook a formula for a lex. Indeed, a recent study has found that curule magistrates acted as rogatores more frequently in the late Republic. Prior to 88, curule magistrates seldom legislated, and when they did it was regarding election of magistrates and declarations of war and peace. ${ }^{439}$ In this earlier period, they used tribunes to pass their bills into law. ${ }^{440}$ Sandberg dates the change in practice to Sulla's reforms, and attributes the change to the crucial role of legislation in the political struggle between the optimates and the populares. When consuls and praetors failed to find the tribunes obliging, they

\footnotetext{
438 See Sandberg (2001: 62) on Caelius' legislation.

${ }^{439}$ Sandberg (2001: 94). This tallies with the theory that consuls' main activity pre-Sulla was campaigning in the field, not regulating matters at Rome.

${ }^{440}$ Sandberg (2001: 97).
} 
summoned the people and proposed measures directly to the assembly. ${ }^{441}$ Therefore, Caelius must have secured popular support in order to pass this measure.

In the face of still more opposition, this time from the consul Servilius, Caelius cancelled his law and put forward two others: one by which tenants received a free year's rent, another cancelling debt (ib. 3.21.1). It appears he did all this in the Forum from his position next to the urban praetor, for then the multitudo made a rush at Trebonius and Caelius drove him from his tribunal. Caelius had won the support of the multitudo. The response of his opponents was swift as they sought to preserve peace in the city, but also their own popularity. Servilius referred the matter to the senate which passed a decree removing Caelius from office and the senate. Then Caelius tried to address a contio but the consul led him from the rostra - a clear sign that there was fear he had won over the people.

Caelius' next move was bold. He pretended he was going to seek the support of Caesar, instead turning to the support of Milo and his gladiators whom he sent to the area around Thurii to win over the farmers (pastores) while he himself reached Casilinum. But when his plans were discovered,

${ }_{441}$ Sandberg (2001: 147). 
and he was shut out of Capua, he changed his mind "periculum veritus, quod conventus arma ceperat atque eum hostis loco habendum existimabat" (Caes. BC 3.21; Livy Per. 111). Caelius may have won the support of the urban multitudo back in Rome, but had not had the opportunity to do the same with the conventus (body of Roman citizens) in Capua. ${ }^{442}$ He had not had the chance to use his rhetorical abilities, nor enourage them with the promise of debt relief since he was now no longer a magistrate. Like Catiline before him, his prestige suffered for not holding office.

Enough of Caesar's version. We are in the rare position of having a candid letter written by one of the protagonists. Caelius writes from Rome around the end of January 48, claiming to be a Caesarian helping out Cicero's Pompeian side. Caelius was with the party that left Rome to join Caesar at Ariminum in 50, but Caelius regrets Cicero did not save him from the type of people that were supporting the Caesarian cause. He laments that if only Appius had been Caesarian and Curio Pompeian, Caelius' hatred of the first and affection for the second would have seen him with the Pompeians in the East rather than with the Caesarians in the West. Instead, because he is so disappointed with Caesar, Caelius has driven plebs and populus from Caesar to the camp of Cicero with his promise of debt relief (Cic. Fam. 8.17). This

${ }_{442}$ For definition, see OLD conventus 3. 
letter reveals that he had the support of a diverse group of citizens, both plebs and populus, not just the multitudo claimed by Caesar.

Dio adds a different perspective to that of Caesar, more favourable to Caelius. According to Dio, Caelius gained a considerable following by offering to help debtors and by waiving rent for tenants. This he did in competition with Trebonius. In Caesar's version, no one wanted his help. With this following Caelius attacked Trebonius (Dio 42.22). Servilius tried to propose a measure dealing with the debt laws, the details of which are lost as Dio does not elucidate. But nothing came of Servilius' proposal as it was vetoed by the tribunes. The consul did succeed in getting Caelius' tablets removed, only to have Caelius attack his assistants and himself directly. Then Servilius barred Caelius from the senate, dragged him from the rostra and smashed his chair - violence on the part of the consul omitted from Caesar's account (42.23). Caelius decided to set out for Campania where Milo was beginning a rebellion so that together they could undermine Caesar. But Dio justifies Milo's conspiracy; alone of the exiles Milo had not been restored by Caesar. Caelius seems to have delayed leaving Rome. Dio says he was being watched and adds that he did not want to leave by stealth as he still thought there was some benefit to be had from his praetor's office. This confidence in the legality of his own position is not mentioned by Caesar, nor is the fact that Servilius granted Caelius 
leave of absence after his relentless appeals. Caelius pretended that he was going to visit Caesar (42.24).

But by the time Caelius found Milo he had been defeated. Shortly after this, the consul declared war on Milo and ordered Caelius to stay in the suburbs to prevent him from stirring up trouble. But Caelius escaped, fled to Milo only to hear that he was dead. Caelius was killed at Bruttium by supporters of Caesar (Dio 42.25). Dio locates his death at a different place and does not include the cavalry as Caesar does, and in so doing makes Caesar appear more responsible for his death. Indeed, one source even has Caelius killed by order of the (very partisan) senate (Vell. Pat. 2.68.2). Having changed sides from pro-senatorial Pompeian to Caesarian, and securing for himself a praetorship in the process, he died when he betrayed Caesar: he tried to get Italy to revolt against Caesar. Yet in Caesar's commentary, Caelius maintained to the end that he was working for Caesar, or at least trying to reach him, but was cut short when Caesar's Gallic and Spanish horsemen garrisoned at Thurii killed him. (Caes. $B C$ 3.22). An ambiguous end for a Roman of shifting loyalties.

Caelius' experience provides evidence for conservative resistance to debt reform, and the difficulty for the reformer in first securing, then maintaining support. Yes, the people were fickle, but the competition for dignitas and 
popularity cannot be underestimated. Caesar, Trebonius, Servilius and Caelius were all competing for the same thing: popular support. Without that, their prestige and power was nothing. The people demonstrated their support by attacking Trebonius. The citizens of Capua demonstrated their support for another man by killing Caelius. These incidents highlight how passionately desperate debtors felt about debt relief. The issue was beyond factional politics: they backed the politician who looked most likely to achieve reform.

As in the case of Catiline, Caesar learnt from Caelius' mistakes and was soon to successfully introduce measures to improve the lot of many citizens. Although it cost Caesar his life also, at least his reforms survived and influenced later Roman law. ${ }^{443}$

\section{CASE STUDY: AGRARIAN REFORM}

Since the early days of the Republic, citizens demanded land from which to earn a livelihood. They applied pressure on the senate for the redistribution of land in the form of both individual viritane allotments and substantial

${ }^{443}$ Frederiksen (1966: 140 f.). 
colonies of thousands. More than twenty agrarian bills for both viritane distributions and colonies are recorded between 486 and 367, at which point veteran colonies become the predominant form of land allocation. While the historicity of the early distributions to urban poor is doubted because the need would have been for defensive colonies of veterans, not relief from urban population pressure, they nevertheless shed light on the late Republic. For, as noted in Chapter Three above, Livy and Dionysius of Halicarnassus, our main sources, are well known for peppering their accounts of the earlier Republic with the late Republican phenomena with which they were more familiar. They used the constitutional workings of the late Republic to add detail to the first 200 years of Republican history because they did not have reliable sources until the third century, when Romans started writing history and stopped relying on legend and the annual lists of consuls. We can therefore use these measures as evidence for the method of reformers, and their opponents, in the late Republic.

With the notable exception of Flaminius' land bill in 232, all other agrarian laws from 366 to 173 were for the establishment of veteran colonies. These were defensive settlements, designed to protect newly annexed territory from encroachment by former inhabitants. When, however, Rome stopped acquiring land in Italy and was reluctant to send colonies overseas, these colonies ceased to be established. Therefore, pressure for the redistribution 
of Campanian land built up, culminating in the lex Sempronia of 133 . There were too many people trying to live off too little land, ${ }^{444}$ hence the need for redistribution of public land. In the last generation of the Republic, the demand for land continued. After several failed attempts by tribunes, this demand was finally satisfied by a lex Julia in 59.

There is disagreement over whether land redistribution was driven by a shortage of men eligible for army recruitment, or by a population increase in the countryside contributing to pressure on Rome. Plutarch believed there was a military motivation to finding land: "The poor, when they found themselves forced off the land, became more and more unwilling to volunteer for military service or even to raise a family" (Ti. Gracc. 8). Until recently, scholars believed a shortage of manpower drove the need to find land for the landless. But now the need for viritane allotments to increase the amount of men eligible for military service in the late second century has been questioned. Nathan Rosenstein has challenged the long held tradition that land grants were needed to "relieve military pressures." 445 Instead, he claims that "year round warfare had become the norm by the later fourth century." 446 He constructs a coherent and convincing argument against the

\footnotetext{
444 Rosenstein (2004: 155).

445 Badian (1972a: 731).

446 Rosenstein (2004: 52).
} 
notion that the practice of long campaigns was introduced in the late third or early second century and caused the rise in landlessness to which Plutarch alludes. De Ligt has added to the debate by suggesting that there was not a decline in population numbers but an increase, as fertility rates rose and rural families became too large for the practice of dividing land amongst sons to be sustainable. ${ }^{447}$ His analysis of the census figures is convincing: there were more Romans sharing less land.

In this section, then, we will examine how these landless citizens secured land allotments. In the earliest period, obstruction of the levy dominates, with occasional mutinies, as we saw in Chapter Three where the plebs used the same methods to gain reform in the areas of debt bondage and patrician domination of office. Tribunes pressured the senate for agrarian reform by preventing the collection of war-tax. There is also some evidence that plebs occupied land to get the attention of the senate. In later periods the landless and their champions bypassed the senate as tribunes took rogationes straight to the people to vote into law.

Some have queried the existence of leges agrariae in the early Republic, alleging that records of such laws are nothing more than accretions from the ${ }^{447}$ De Ligt (2007). 
late Republic. ${ }^{448}$ But these researchers are too pessimistic and would have us believe none of Livy if the slightest repetition or theme can be identified. Patterns are of course going to develop in an examination of agrarian reform. We cannot pass off all accounts of agrarian proposals between 486 and 367 as inspired by the times of the Gracchi; similarly we cannot assume frequent lack of successful reform or redistribution translates into agrarian proposals not being reported. ${ }^{449}$ Cornell further emphasises the historicity of the Licinio-Sextian reforms, stating that we can see the sources struggling to account for features which had become obsolete by the time of writing. We do need, however, to be wary of the adoption of late Republican political vocabulary and characteristics of leaders of the same period, most notably the Gracchi and Saturninus. 450

The first recorded attempt to distribute land was that of the consul Sp. Cassius in 486 BC: his proposal that land confiscated from the conquered Hernici be divided amongst Latins and plebs was vetoed by his colleague with the support of the senate and some of the plebs on the grounds that the land should only be shared out amongst citizens; for they did not want to share the benefits with allies (Livy, 2.41; Dion. Hal. 8.69-71). Two thirds of

\footnotetext{
${ }^{448}$ Forsythe (2005).

${ }^{449}$ Cornell (1995: 268-271).

${ }^{450}$ Cornell (1995: 327 f.). For more on the technique of the sources see Cornell (1986: 52-76).
} 
the land confiscated from the Herninici (now allies) was to be divided amongst Latins and plebs and a third restored to the Hernici (Livy 2.41.3). Dionysius records that the land for division was not that of the Hernici but "he determined to divide among the people a certain large tract of land belonging to the state which had been neglected and was then in the possession of the richest men" (8.69.3) and the land was to be assigned not only to Latins, but the recently enfranchised Hernici too (8.69.4). Cassius failed despite calling the Latins and Hernici into Rome to vote (Dion. Hal. 8.72.4).

Modern scholars, however, have been suspicious of the ancient sources because they appear to have derived elements of their account of the first lex agraria from that of $\mathrm{Ti}$. Gracchus (such as senatorial reluctance to redistribute land held by the wealthy) and also from C. Gracchus' proposal to extend citizenship to the Italians (the opposition of C. Fannius the model). ${ }^{451}$ But there is no reason to doubt that the Hernician land needed settling to shore up defences against the surrounding Aequi and Volsci, and at the same time to encourage the Romanisation of the new citizens by sending settlers from the city and environs, though Cornell disagrees. Cornell believes the confusion can be attributed to the sources combining

451 See Forsythe (2005: 193-195). 
the agrarian reform with the terms of the Hernician treaty concluded in the same year, but stresses that this does not render the proposal a fiction; rather the bill might have come to resemble the provisions of the treaty due to confusion or "willful manipulation" ${ }^{452}$

E. T. Salmon criticises the accounts in Livy and Dionysius of Halicarnassus, asserting that their reports of disagreement in the early Republic over the desirability of sending out a colony must be anachronistic, reflecting first century dissensions, because there was definitely a need to defend Rome from agressors at the time. ${ }^{453}$ While his suggestion is logical, he need not completely deny the existence of reform just because he disagrees with the detail. We should follow the lead of Cornell, who adopts his characteristically positive stance and postulates a genuine core of the tradition, in this case that $\mathrm{Sp}$. Cassius proposed an agrarian law. ${ }^{454}$ Indeed, the plebs' refusal to share land with the allies reminds us of the same reluctance Tiberius Gracchus experienced in 133, when he had to modify his

\footnotetext{
${ }^{452}$ Cornell (1995: 271).

453 Salmon (1969: 115 with refs n. 203).

${ }^{454}$ Cornell (1995: 271).
} 
original proposal to share public land between citizens and Italians when the bill proved unpopular with the voters (App. BC 1.9.35f.; 1.11.44f.). ${ }^{455}$

The idea of a lex agraria remained attractive to the plebs, but a series of conservative magistrates prevented its passage (Livy 2.42). Finally, in 481, the tribune Sp. Licinius tried to enforce land distribution by obstructing the levy, but he incurred the odium of the plebs for misuse of his tribunician power and was opposed by his fellow tribunes who helped the consuls complete the enrolment (Livy 2.43.3-4; 44.1; Dion. Hal. 9.1.3-2.2). Again more recent historians are unhappy with our primary sources - Ogilvie calls Livy to task for applying anachronistic material from the late to the early Republic, specifically the repeated allusion to the use of the tribunician veto which some believe was not used until the time of Ti. Gracchus. ${ }^{456}$ In 480 another tribune, Ti. Pontificius, proposed an agrarian law and again impeded the levy but was overcome by men of consular rank who used their gratia and auctoritas to convince the other tribunes to oppose him (Livy 2.44; Dion. Hal. 9.5.1). These repeated incidents of use of the levy for leverage in the early Republic tell us that the practice persisted into the later

455 Appian implies the inclusion of the Italians, while Plutarch makes no mention of them. Despite the best efforts of Bernstein (1978) to amalgamate accounts, Badian (1979: 455f.) has argued that the only conclusion we can make is that the Italians got nothing from the provisions of the lex Sempronia.

456 Ogilvie (1965: 352). Forsythe (2005: 171) and Badian (1972: 697-700) agree that the veto was seldom used before the Gracchi. See also Dion. Hal. 9.1.3-2.2. 
Republic - Livy used examples from his own period to illustrate previous periods, and with his later books lost he cannot tell us that there was resistance in the later Republic. This material may not have captured the imagination of his epitimator and so has not survived.

Popular pressure for land persisted. In 479 the consul Caeso Fabius suggested to the senate that concordia be secured between patricians and plebs by preempting any tribunician proposal for land distribution by senators proposing it themselves, claiming it only fair to distribute territory taken in war to those whose sweat and blood had won it. The patricians rebuffed him (Livy 2.48). Despite Caeso's failure, we see here a theme that develops in the late Republic, only with a change in protagonists. As patrician families died out, conservative senators replaced patricians in the competition with popularis politicians to win the people's support by proposing bills in their interest.

The popular interest would be frustrated once more before the passage of the first successful land bill, again due to clashes between tribunes and senators. The tribunes Q. Considius and T. Genucius "began to stir up the plebs with their customary poisonous brew: an agrarian law" in 476 and responded to senatorial resistance by attacking individuals, including Menenius, the consul of the previous year, whom they impeached for failing 
to come to the aid of the Fabii at Cremera (Livy 2.52). The condemnation of Menenius stirred up resentment amongst the patricians so that they refused land allotment (Dion. Hal. 9.27.4). The status of the land bill is clarified by Dionysius. ${ }^{457}$ In 473 the tribune Cn. Genucius tried to convince the consuls to carry out the senatorial decree on the distribution of land drafted in 485 to weaken the influence of Sp. Cassius, but the consuls refused, claiming the senate had given the job of drawing up the decree to the consuls of 485 (immediately following the consulship of Cassius and Verginius: 8.76.2), an argument which the tribune denied by replying that senatorial decrees were only valid for a year (9.37.2).

The first lex agraria was finally passed in 467 BC after nearly twenty years of failed attempts. In 470 the consul Aemilius had advocated giving land to the plebs; now in his second consulship, he had the backing of the tribunes. The senators who stood to lose land through its proposal criticised the consul for acting like a tribune (Livy 3.1.6). A lex or plebiscitum was passed instructing the praetor to hold elections for the triumviri agro dando who assigned land to colonists at Antium, thus appeasing those who had stood to be disadvantaged by the redistribution of public land in their

457 Broughton (1951: 29) seems to have got it wrong here when he says Genucius "accused the Consuls of 474 of ignoring the agrarian law of Cassius," for the law was never passed as we can see from Livy and Dionysius. 
possession. ${ }^{458}$ As some plebs did not want to become farmers, colonists from Italian towns (Volsci according to Livy; Latins and Herenici to Dionysius) were also added to make up the numbers because "the rest of the multitude preferred to demand land at Rome than to accept it elsewhere" (Livy 3.1.7).

There is very brief mention made by the usually long-winded Dionysius (9.69.1), but omitted by Livy, of an agrarian bill, proposed by the tribune Sex. Titius in 462 BC, being deferred to "more suitable times" (both consuls were out of the city in command of armies, one attacking the Volsci, the other defending the allied Hernici: Livy 3.8).

The absence of consuls and soldiers did not stop another tribune from taking the opportunity in the same year to introduce a different bill in the people's interest. The tribune C. Terentilius Harsa was not won over by the same argument as his colleague to wait until Rome enjoyed peace when he proposed a board of five be appointed to codify the laws which regulated consular imperium. Instead he put it to the plebs that the consuls were victimising the people by directing laws against them. It will pay to examine the ensuing battle between tribunes and magistrates to shed light on the tactics used in the late Republic, for they were likely similar given

458 See also Dion. Hal. 9.59.2. 
Livy is the source. Popular pressure eventually paid off, even if in an unexpected way.

Threats to boycott the levy were pitted against religious obstructions. Initially, the praefectus urbi intervened, summoned the senate and talked against Terentilius' bill, so that the other tribunes were able to convince their colleague to postpone the matter (Livy 3.9). The whole college of tribunes picked up the bill the next year and, in the face of staunch opposition, they alleged that omens and threats from the Volsci, Aequi and even the colony and loyal neighbour Antium were being invented to distract citizens from the need for limiting consular imperium (Livy 3.10). The tribunes resolved unanimously to obstruct the levy: for were it held, they alleged, citizens would have been sent out to fight a fabricated enemy when they ought to have been in the city attending to the bill on consular imperium (Livy 3.11). Opposition to the bill persisted, due especially to the efforts of the patrician Quinctius Caeso (Livy 3.11-13) and then the diversionary tactics of the patricians in general (Livy 3.14). The bill was still a topic of political interest in 460, so that when the Sabine Ap. Hordeonius seized the Capitol the tribunes again claimed it was a patrician ruse to distract the plebeians from the law and summoned the populus to put down their arms and vote the law in via a concilium plebis (Livy 3.16.6). Their hopes were dashed when the relatively conciliatory consul Valerius was killed reclaiming the Capitol and 
the man elected suffect was none other than the father of Quinctius Caeso (Livy 3.15-20).

Compromise was finally reached so that the tribunes would postpone the vote on their bill and the consuls would not lead the army out of the city (Livy 3.21). Livy reports that the danger of attacks from the Aequi and Volsci in 459 made the tribunes let the war take precedence over their proposal (3.22). Re-elected again in 459 (for the third time) Verginius and Volscius faced consular obstruction of the passage of their law (the consuls obtained a two month delay in summoning the assembly to vote as they planned to use the period to convince the people that it bore secret lies (3.25). The tribunes tried, as usual (suo more, Livy 3.25.9) to prevent the levy, but the plebeians obligingly armed themselves because of a massive Sabine onslaught (two large armies were levied, Livy 3.26). Once the Sabine threat had been reduced by Cincinnatus in 458, the tribunes again tried to get their measure on consular imperium passed, but the senate put them off again (Livy 3.29). The tribunes were elected for a fifth time in 457 and managed to carry a law increasing the number of tribunes to ten, with the senate providing that no tribune be elected to the post in successive years. They failed yet again to pass the measure on consular imperium due to a fresh Sabine incursion which made it necessary for them to cease interfering with the levy (Livy 3.30). 
The six years of wrangling finally paid off, but not as expected. In 456 the new tribunes kept up the effort to pass the law limiting consular imperium but instead one of their number, L. Icilius, carried a plebiscite given very brief notice in Livy "de Aventino publicando" (3.31.1; the Icilian law was a lex sacrata, i.e. an oath taken by the plebs, 3.32.7). Forsythe believes Livy here depicts the type of land law that really belonged to the early Republic (rather than all the others which he considers retrojected from the late Republic). He suggests it "somehow concerned the status of landholdings on the Aventine", perhaps distinguishing the sacred land of shrines from the surrounding public and private ground - hence the bronze pillar inscribed with the law in the temple of Diana (Dion. Hal. 10.32.4). But late annalists not only turned this into a late Republican-style law to distribute land to plebs but also linked the name of the rogator, Icilius, to a family of reforming Icilii. ${ }^{459}$ Indeed Dionysius fleshes out Livy's sparse notice in just such a way: Icilius proposed

that the region called the Aventine be divided among the plebeians for the building of houses. This is a hill of moderate height, not less than twelve stades in circuit, and is included within the city; not all of it was then inhabited, but it was public land and thickly wooded... All the parcels of land held by private citizens, if justly acquired, should remain in the possession of the owners, but such parcels as had been taken by force or

459 Forsythe (2005: $207 \mathrm{f}$.). Icillius was also the first tribune to experiment with convening and addressing the senate (Dion. Hal. 10.31.1-2). 
fraud by any persons and built upon should be turned over to the populace and the present occupants reimbursed for their expenditures according to the appraisal of the arbitrators; all the remainder, belonging to the public, the populace should receive free of cost and divide up among themselves. (Dion. Hal. 10.31.2, 32.2)

The redistribution provision does indeed resemble Tiberius Gracchus' lex agraria. Cornell has a different interpretation of the law: following de Sanctis he believes it was a "unilateral decision of the plebs to occupy public land on the Aventine, and to protect individual settlers against eviction, if necessary by force." 460 Cornell holds that this was the nature of all plebiscites from the early fifth century, before the legal recognition of the leges sacratae. If Cornell is correct, then we have discovered another form of popular demonstration: land occupation.

The tribune Poetilius used the familiar tactic of obstructing the levy when he was elected on a platform of agrarian reform in 441 . He tried to gain popular support, by what methods we do not know. Livy only tells us that his efforts were fruitless. Poetilius was no radical, however: he followed tradition and tried to get the consuls to bring the question before the senate. At this point, Livy includes the curious detail: "After a great struggle he succeeded so far that the senate should be consulted as to whether the next elections should be held for consuls or for consular tribunes. They ordered

${ }^{460}$ Cornell (1995: 261 f.). 
consuls to be elected." It appears Poetilius had failed to convince the consuls to discuss his land redistribution measure, but succeeded in getting them to talk about consular tribunes. Poetilius, frustrated by the obstruction of the consuls, then threatened to impede the levy if land was not redistributed. Livy portrays his threat as pointless because Rome was not then at war or preparing to go to war (4.12.3-5).

The next agrarian proposal again resembled those of the late Republic with its provision to redistribute to individuals land annexed from the enemy (in effect ager publicus), which would involve confiscation of land that had fallen into the hands of the wealthy. The bill was put forward in 416 by the tribunes S. Maecilius and (M.) Metilius, but their fellow tribunes vetoed it. Certainly those who stood to lose land opposed the bill: there was namecalling in the senate (Livy 4.48.1-16). There is no record of the involvement of the populus Romanus or what motivated the tribunes.

Two years later land was again the focus of popular demonstrations: in 414 the tribune M. Sextius proposed to send a colony to Bolae, which had been captured from the Aequi, against the wishes of the violent and abusive consular tribune Postumius. The tribune argued that "those who had captured Bolae deserved that the city and its territory should belong to them," to which Postumius exclaimed, "It will be a bad thing for my soldiers 
if they do not keep quiet." His soldiers responded by taking matters into their own hands: they mutinied and killed him (Livy 4.49-50). Although the final victory lay with the senate, since an interrex was appointed after the tribunes vetoed the election of consuls, the action of the soldiers served to remind the senate of the danger of frustrating the will of the people.

The year after the soldiers expressed their dissatisfaction with Postumius, the consuls alienated the urban plebs. These poor city folk were not so naïve as to fail to notice the speed with which the consuls executed members of their order involved in the mutiny, yet refused to advance measures brought forward in their own interests. Livy suggests that had the senators shared out the vacant territory captured from the Aequi they might have saved themselves from plebeian resentment and the pressure to redistribute the publici agri they had unjustly occupied (Livy 4.51.2-6). The plebs came close to having the issue resolved in 412 when the tribune L. Icilius began to agitate amongst the city dwellers and announced proposals to deal with the land problem, only to lose momentum when the city was hit by an outbreak of pestilence. Although disease brought death to many, Livy reports that it was not considered as worrisome as the proposed land bill. Clearly he reflects the senators' view (Livy 4.52.1-3). After a quiet year, due to disease and famine, agitation for agrarian laws was revived by the tribune $\mathrm{M}$. Menenius. In 410 he pressured the senate to support his bill after gaining 
popular support to obstruct the levy (no one would take the oath, Livy 4.53.3). Menenius lost this support, however, after the enemy captured Carventum, and so his movement lost its impetus especially as those who had refused the oath were brought before the consul Valerius (Livy 4.53.9).

Nine years then lapsed before Livy records another attempted land distribution: in 401 the tribunes proposed an agrarian law and at the same time prevented the collection of war-tax, thus saving the money of those not serving in the army, but simultaneously the shortfall of cash prevented soldiers from being paid. The combination of threatened agrarian reform and actual witholding of tributum did bring success for the plebeians, although not in the form of an agrarian law. Instead, for the first time a plebeian was elected consular tribune (Livy 5.12.3-9). Once more, the interests of the elite plebeians triumphed over those of the poor. ${ }^{461}$

It was not long, however, before the plebs received land. The vote was close in 393 when suffect-consul Lucretius advocated that members of the plebs settled Veii, in response to the unattractive proposal that Rome be moved to Veii, which had been defeated by a majority of one tribe. The senate was so pleased that Rome was staying put that the next day it passed a decree that

461 See Chapter Three for further instances, such as elite plebeians using the numerical superiority of their poorer brothers to compel the patricians to share office. 
seven iugera of the Veientine territory should be allotted to each plebeian (Livy 5.30.8; cf. Diod. 14.102.4). This tactic, of introducing an extreme proposal (moving Rome to Veii), in order to achieve a more modest one is reminiscent of the technique used in the late Republic by Pompey's supporters to secure for him command against the pirates.

The desire for conquered land to be given to the people was still strong in 387 when the tribune L. Sicinius proposed a bill to distribute Pomptine land to plebs: "the people (populus) attended the assembly in greater numbers and showed a more eager desire for land than they had done" (Livy 6.6.1). Here Livy uses the term populus rather than his usual plebs, which may indicate the widespread appeal of the bill to citizens from all social groups: all Romans stood to gain from this new distribution of land.

The final piece of land reform in this period occurred in 367 as part of the famous Licinio-Sextian rogations. The tribunes Licinus and Sextius proposed relief from debt and the institution of land limits, along with redistribution of political power. ${ }^{462}$ They set maximum amounts of public land to be possessed at 500 iugera, the provision Ti. Gracchus revived in 133 BC (Livy 6.35.4-10; Dion. Hal. 14.12 .22; Plut. Cam. 39).

462 See above on the provisions that interest paid on debts be deducted from the principal and what remained paid in three instalments, and that one consul had to be plebeian. 
Following this reform, our sources record no further calls for land laws for more than seventy years. And then, once they reappear they are for veteran colonies (except for the lex Flaminia in 232) until 173, when pressure for the redistribution of Campanian land built up. This may be evidence for the success of 119 years of popular pressure culminating in the Licinio-Sextian reform: the redistribution of public land held in excess of the legal limit had relieved the land shortage problem. Or we may just be missing some piece of evidence that would prove otherwise. Yet we must base our conclusions on the evidence in our possession. Therefore, going on what we have, we can conclude that 367 was a watershed year that saw a significant popular victory in the area of land reform.

In 296 land distribution resumed, but this time the people wanted magistrates to send out colonists to defend newly conquered territory. Volunteers were not forthcoming as the purpose of the colony was military, not agricultural. The citizens legislated for the praetor P. Sempronius to take a vote to elect triumviri to found colonies at Minturnae and Sinuessa (Livy 10.21.4-10; Vell. Pat. 1.14). Livy's record reveals how the vote was organised:

It was arranged that the tribunes of the plebs should get a plebiscite passed requiring $\mathrm{P}$. Sempronius, the praetor, to appoint commissioners for 
the founding of colonies in those spots. But it was not easy to find people to be sent to what was practically a permanent outpost in a dangerously hostile country, instead of having fields allotted to them for cultivation. $(10.21 .9-10)$

The senate persuaded the tribuni plebis to bring a bill to the people, proposing that the praetor choose commissioners to establish colonies. The senate decided the need for the territory to be garrisoned, and the people acknowledged the desirability when they voted the bill into law, although the colonies themselves were not a popular lifestyle choice. The refusal of citizens, rural or urban, to take up the offer to go and live in a dangerous outpost illustrates their freedom to choose.

Following this incident, it appears there were further calls for distribution. The nature of the demand, however, is unclear. All we know is that in 290 the consul Curius "refused more than the regular assignment of land" (Val. Max. 4.3.5). There was pressure for more land distribution than the consul was prepared to offer. It is odd, then, that there is another significant hiatus in our souces at this point. Perhaps Curius' land allocation satisfied the need, although this seems unlikely given the implication in Valerius that demand exceeded supply.

A lengthy 58 years passed before the next lex agraria during the infamous tribunate of C. Flaminius in 232. It has been suggested that Flaminius' 
"brilliant career had demonstrated the theoretical sovereignty of Roman People." 463 He took an agrarian bill to the people despite senatorial opposition. The law distributed land in the north, the ager Gallicus and Picenus, in viritane allotments to Roman citizens in the north (Polyb. 2.21.78; Cic. Brut. 57). Flaminius' ability to pass his agrarian law even though he lacked senatorial support shows that he had tapped into voters outside the senate who were wealthy enough to have votes which counted. As we saw in Chapter Two, men from all walks of life had clout in legislative assemblies due to the migration to Rome of many rural tribesmen who remained enrolled on rural lists during the period in which no censors carried out their duty. Their residence in Rome, and probable underemployment, gave them the chance to vote and so challenge the vote of their wealthy tribesmen, still resident in the countryside who could afford the time and expense to travel to Rome. I suggest Flaminius tapped into this new group. ${ }^{464}$ His success depended on the urban drift of rural tribules following the first Punic war.

Flaminius challenged senatorial authority in order to promote the interests of disgruntled veterans of the war against Carthage and send them out to garrison newly annexed territory in the north. It was a happy coincidence

463 Scullard (1973: 44).

${ }^{464}$ Mouritsen (2001) thinks he mobilised lower classes. 
to the homo novus that he might gain some new supporters in the process. So keen was he to have his land bill passed that he took his proposal straight to the assembly without first consulting the senate - a move at least in part due to senatorial opposition. ${ }^{465}$ Ninety nine years later Ti. Gracchus likewise bypassed the senate when he sought agrarian reform. While the sources do not record them, there were four reasons for Flaminius' bold and unprecedented action. First, he and those who supported his bill gained a new group of clients, although it would have been difficult for the majority of the settlers to make the journey to Rome to exercise their right to vote nonetheless, these men may once have been other men's clients, but were now Flaminius'. ${ }^{466}$ Second, the initiative was no doubt a defensive one for the area once populated by Senones had been conquered and subsequently abandoned 50 years earlier. Moreover the Latin colony of Ariminum, founded in 268, was struggling under pressure from Celtic tribes, so Flaminius' settlement programme would safeguard Rome's defensive buffer

465 Senatorial opposition arose from the political implications of individual allotments of land for Roman citizens at a significant distance from Rome. Usually citizenship was renounced and such colonies became Latin, but with the spread of municipalities oligarchs feared loss of power. See Feig Vishnia (1996:26 f.).

466 Eckstein (1987: 10). He may have had some potent senatorial support in the form of L. Caecilius Metellus (ib. 11 with n. 25). Pliny (NH 7.139-40) records that Metellus was appointed to a land commission and Flaminius' law was the only one during this period to provide him with the opportunity. Feig Vishnia (1996: 32-24) believes Flaminius also enjoyed the support of the prestigious Aemilii and Carvilius, the colleague of Fabius Maximus during his second consulship (confusion over the date is due to Cic. Sen. 11), who remained silent while Fabius Maximus opposed Flaminius because the latter helped him achieve the consulship after a messy divorce. Scipiones may have supported him). 
on her north-eastern border. ${ }^{467}$ Third, he sought to placate a disgruntled proletariat, including veterans of the first Punic war who had lost land in Sicily, and reduce the suffering of the landless by providing them with allotments. ${ }^{468}$ In addition, the fertile land of the Po valley may have helped alleviate food shortages at Rome. The success of the lex Flaminia illustrates the ability of the people to have bills passed in their favour once they have secured a friendly tribune.

As noted above, attention turned from defensive colonies of veterans ${ }^{469}$ to sending settlers out to farm allotments individually. This change of tack put pressure on the fertile land of Campania. Consequently, in 173 the consul Postumius was sent to recover from private possessors public land there (Livy 42.1.6, 9.7.8). In 165 also P. Cornelius Lentulus, urban praetor, was requested by the senate to reclaim Campanian public land (Cic. Leg. Agr. 2.82). More defensive settlements, nonetheless, were still being sent out: decemvirs were elected to divide unoccupied land in Liguria and Gaul

\footnotetext{
${ }^{467}$ Eckstein (1987:11).

${ }^{468}$ Feig Vishnia (1996: 30 f.)

${ }^{469}$ Four further incidents have survived in the historical record. First, three commissioners were sent out to assign land to colonists at Placentia and Cremona (Polyb. 3.40.5 and 9-10). Then in $201 \mathrm{M}$. Iunius Pennus, the urban praetor, held elections for a land commission to assign land in Samnium and Apulia to Scipio's veterans (Livy 31.4.1-3, 49.5). In 199 C. Sergius, promagistrate, had his command prorogued so he could assign land to veterans (Livy 32.1.6). Finally, in 180 a commission of three was appointed to assess a Latin colony at Pisa (Livy 40.43.1).
} 
between Roman and Latin settlers (Livy 42.4.3-4). Popular pressure started to peak around 140, which was probably the year the consul Laelius made his famous agrarian proposal, but withdrew it in the face of senatorial opposition (Plut. Ti. Gracc. 8.3-4).

And then came Tiberius Gracchus. During his tribunate in 133, Ti. Gracchus passed a measure setting up a commission of three men to redistribute public land held in excess of the legal maximum to the poor. The tribune may also have limited the term of military service and reaffirmed the right of appeal to the people and made equestrians members of juries.

As we explained above, Plutarch and Appian, and perhaps Ti. Gracchus too, misunderstood the cause of the land shortage. They wrongly attributed the shortage to an increase in big estates, with land purchased by wealthy aristocrats off struggling peasants, which relied more on slave labour than did the assidui. This factor, in tandem with the trend for men to spend long periods in military service overseas, resulted in citizens losing their farms. This interpretation is incorrect, but it is right to notice that there was a land shortage. The aim of the law was to provide land for those who had none because there were "too many people attempting to start out in life with too 
little land." 470 Colonisation ceased in 173 once there was no land left to distribute in Italy; for Rome was reluctant to send out overseas colonies. ${ }^{471}$

The bulk of Tiberius' supporters came from the countryside. Many were land hungry veterans. It appears that the senate was hesitant to take on these retired soldiers. Obviously rural dwellers were important supporters to have as they helped fend off attacks from conservative politicians. Therefore, so as long as Tiberius had the support of rural plebs, the senate did not act directly (only through Octavius' veto), but he was attacked once he lost their backing after the country folk (and seasonal workers from the city) returned to the harvest (App. BC 1.14). Urban plebs did offer some protection too. We find that without their support Gaius Gracchus and Saturninus were isolated and therefore easy pickings after the intransigence of the conservative bloc in the senate drove them to act illegally.

Tiberius' tribunate also raised the issue of the legitimate expression of the people's will, which had been used to justify the repeated conflict between senators who acted as representatives of popular interests and those who

\footnotetext{
470 Rosenstein (2004: 155ff.) acknowledges other factors also contributed to the need for land reform, such as the need to get recent immigrants out of the city and on the land.

471 Keaveney (2007: 17; cf. 42), noting that when Sulla sent out colonists as part of his reforms in 81 , it was to land won not by conquest but through proscriptions, so great was the lack of land available for distribution.
} 
sought to defend the status quo and senatorial domination in the public sphere. Tiberius Gracchus used this argument for the peaceful deposition of Octavius (Plut. Ti. Gracc. 15). ${ }^{472}$

The lex Sempronia was a success. Many citizens benefitted from the redistribution of land held in excess of the legal maximum as set out in the lex Licinia Sextia. But it did not take long for some of the old habits to creep back in, so that by 123 , the tribunate of Tiberius' brother C. Gracchus, the agrarian law needed to be re-enacted. The following year the conservative senators reacted to the reformer. They persuaded the tribune M. Livius Drusus to propose twelve colonies of poor, in so doing undermining $\mathrm{C}$. Gracchus' colonies (App. BC 1.23; Plut. C. Gracc. 9.2).

In fewer than fifteen years, factional fighting within the senate combined with the influx of money to Rome from imperial expansion saw the end of land grants for the poor. The Gracchan law was ignored and the condition of the poor deteriorated as the wealthy began to buy up land legally (after the introduction of a measure which permitted the holders to sell land about

\footnotetext{
472 Nippel (1995: 56), e.g. a vetoing tribune might be expelled justifiably if he contravened the will of the people. Badian (1972: 7098ff.) agrees that the principle was not new: "the tribune is supposed to act as the champion of the people and in its interest" (709). The tribune Gabinius threatened to depose his colleague Trebellius in 67 when the latter vetoed his proposal to give Pompey a special command to deal with the pirates (Plut. Pomp. 25; Dio 36.30.1 ff.).
} 
which they had quarrelled) or even found reasons to seize it by force. Ultimately, the tribune Sp. Thorius secured the passage of a bill bringing an end to the redistribution of public land. Appian comments that the plebs had lost everything and were reduced to unemployment (BC 1.27).

The plebs did not give up hope, however, as they continued to apply pressure and in so doing succeeded in stimulating further attempts to legislate in their interest. Most notable were the efforts of Saturninus to provide for Marius' veterans during his tribunates in 103 and 100 BC. 473 The case of Saturninus illustrates the methods tribunes used during this period to encourage people to participate in legislative assemblies in Rome. First he saw to it that the tribal assemblies supported his bill to allocate each Marian veteran 100 iugera of land in Africa (Asc. 80C; Auct. Vir. Ill. 73.1). We have more evidence on his second tribunate, during which Saturninus introduced measures on food and land distribution. His technique was to send messengers to those citizens resident in the country districts to inform them of the comitia on the lex agraria that would divide amongst Marian veterans the land which the Cimbri had seized in Gaul. Appian (BC 1.29) claims that the tribune could be sure of their support as they had served in the army under Marius. These may have been the same soldiers Plutarch

473 See on Saturninus Badian (1962a: 21 -219). 
states had joined with the needy rabble and secured the election of Marius and the defeat of Metellus (Mar. 28.5). Saturninus had already in 103 gained the support of the equestrians, if he had not already won them over through his amicitia with Marius, by his lex de maiestate which delivered to an equestrian jury the power to try cases of maiestas. 474

But Saturninus' plans unravelled when his rural supporters came to blows with the city dwellers who opposed the bill because the agrarian law stood to advantage Italians over the demos (BC 1.30). ${ }^{475}$ The law was passed per vim after the ochlos announced they had heard thunder, and so no assembly could be held (App. BC 130; Livy. Ep. 69). Saturninus and fellow tribunes attacked their opponents, forcing them from the rostra (App. BC 1.30). This was a reasonable response as these men, unnamed by Appian, had acted illegally. As private citizens, they had seized the rostra in an effort to prevent the passage of the laws using the pretext of bad omens. But since Saturninus' reforms were carried with violence and against the auspices, they would later be annulled. Although the year of his second tribunate began well, with Marius and his veterans supporting Saturninus' legislative programme, it turned sour, first with this scuffle in the Forum, then with

474 Auct. Ad Her. 2.17; Cic. De Or. 2.107, 109, 164, 197-201; Inv. 2.53; Part.Or. 105; Sall. Hist. $1.62 \mathrm{M}$.

475 By "Italians" Appian refers to the Marian veterans living in the Italian countryside, as Brunt (1988: 279) suggests. 
further violence at consular elections midyear. The senate passed the SCU. Saturninus was killed when the crowd pelted him and the other men sheltering alongside him in the senate house with roof tiles on the first day of what would have been his third term as tribune (App. BC 1.32-33; cf. Cic. Rab. Perd. 20, Val. Max. 3.2.18 Dio 37.26). With Saturninus and Glaucia dead, and Marius' influence in serious decline, the veterans lacked a leader to promote their interests: the land distributions were never carried out. ${ }^{476}$

It is impossible to be sure of Saturninus' aims. Our task is complicated by the hostility of the ancient sources. We ought to be wary of Appian's portrayal of the popularis reformer, for he struggles to be objective in his account of Saturninus. His attitude is best characterised in his words on the condition of Rome following the death of Saturninus and his allies:

Freedom, democracy, laws, reputation, official position, were no longer of any use to anybody, since even the office of tribune, which had been devised for the restraint of wrong-doers and the protection of the plebeians, and was sacred and inviolable, now was guilty of such outrages and suffered such indignities (App. BC 1.33).

Here Appian's lack of sympathy for Saturninius and his modus operandi is made clear, but is understandable when we recall that history is written by

\footnotetext{
476 Keaveney (2007: 25); Badian (1958: 211 n. 2) and Evans (1994: 121); Brunt (1988: 278-280). The movement to find land for veterans continued, but with staunch opposition from men from the countryside, mobilised by magistrates from Rome. Saturninus' colleague Sex. Titius, one of Saturninus' supporters, passed a land law in 99 only to have it annulled by a decree of the college of augurs (Cic. Leg. 2.14 and 31).
} 
the winners, to justify their successes and vilify their opponents. In addition, like his predecessor Tiberius Gracchus, Saturninus' hands-on approach upset his opponents who excused their hostility by alleging he broke with tradition, only to do the same themselves by hypocritically doing away with the ancestors' restraint and by repeated use of obnuntiation and veto. As Appian himself states above, the tribunate had been violated by the actions of Saturninus' opponents.

The urban plebs were a selfish bunch, and on more than one occasion demonstrated jealous protection of their privileges. Livius Drusus had his successful political career undone by his attempt to secure land distribution for Latins and Italians, so negative was the response from urban plebs. In 91 the consuls summoned Etruscans and Umbrians to Rome to protest against the tribune Livius Drusus' law. The consuls appealed to the instinct of selfpreservation in these men, suggesting that the proposed colonies would put their use of public land in jeopardy, and instilling fear in some that they would lose private holdings (App. BC 1.35; Auct. Ill. 66). Worried by rumours about a plot on his life he worked from home, but was assassinated there one evening, despite his precautions (App. BC 1.36). 
Cicero turned popularis to prevent the passage of Rullus's land bill in 63 BC. 477 Sage believes Caesar and Rullus tried to set Cicero up by offering him the chance to participate in a piece of popular legislation. They expected him to react as he did, and so show himself to be the supporter of the status quo, not the popularis he pretended to be in his speech to the people. 478 Had Rullus chosen his moment in any year other than the one in which Cicero was determined to establish his position as senior statesman, his bill would have stood a better chance of success. Against the skilled orator, the naïve tribune stood not a chance, despite the benefits to the state of his proposal. Cicero's victory illustrates the important role of persuasion in politics. In the days before mass media, those with the power of persuasion prevailed.

Three years later, Cicero was supporting a land bill in the face of stiff opposition from the conservative quarter of the senate, including the consul Metellus Celer. The tribune L. Flavius had proposed that Pompey's veterans be given land, some public, the rest purchased with Pompey's new revenues. Unlike Rullus' bill, provisions were added to protect those currently in possession of land. But the conservative senators won and

\footnotetext{
${ }_{477}$ Leg. Agr.; Rab. Perd. 32; Att. 2.1.3; Sull. 65; Pis. 4; Pliny NH 7.117; 8.210; Plut. Cic. 12.2-5; Dio 37.25.4.

478 Sage (1921: 230-236).
} 
blocked the passage of Flavius' agrarian bill (Cic. Att. 1.18.6, 19.4; 2.1.6-8; Dio 37.49f.). The refusal of these senators to compromise was understandable from the perspective of competition amongst senators for auctoritas. The Pompeians would have won a great deal of prestige had they provided land for the veterans. The intransigence of the senators backfired, however, when Pompey, Caesar and Crassus joined forces and formed the first triumvirate in order to get what they wanted.

One of their first achievements was the election of Caesar to the consulship. From this position he proposed legislation, the passage of which was obstructed by his consular colleague Bibulus. Caesar nonetheless passed an agrarian law early in the year, and added another to distribute Campanian land to indigent citizens who had families. 479

\section{CONCLUSION: WHAT KIND OF DEMOCRACY?}

Popular pressure forced the senate to respond to food crises. The senate received added impetus from the threat of individual reformers, and the more conservative senators struggled to cope with the emergence of the popularis politicians and their new ways of operating based on winning

${ }^{479}$ MRR 2: $187 \mathrm{f}$. 
popular support from the senate. The old guard sought to provide subsidised food in order to maintain stability and preserve the status quo. In this way, then, the people had political power.

The prestige that the people's support brought with it persuaded popularis politicians to restore tribunician power. Pompey saw that the popular backing derived from the restoration would help secure his position and election to the consulship. Those ambitious politicians who lacked the traditional forms of support needed the favour of the people to take on the more established nobiles in the competition for dignitas and auctoritas.

Conservative senators resisted debt reform, making it an uphill task for reformers to secure and maintain popular support. Again, competition for dignitas and popularity caused problems, such that Caesar, Trebonius, Servilius and Caelius fought for the people's favour. In the end, the people brought political success to those who promised them the most.

Democratic elements did exist in the late Roman Republic. The demos or populus Romanus made demands and these were met, eventually, during this period, with more success than in earlier periods. The achievements were due to the popular power that exerted itself in the form of resistance to 
senatorial commands and demonstrations of support for those who would pass measures that improved conditions for the needy. 
CHAPTER 5: DEMONSTRATIONS AND COLLECTIVE ACTION III:

CONTIONES, LEGISLATIVE ASSEMBLIES, TRIALS, LUDI ET

GLADIATORES, TRIUMPHS, CHAMPIONS, FUNERALS, ELECTIONS

\section{AND SENATORIAL RESPONSES}

The investigation so far reveals that citizens who belonged to the senatorial and equestrian orders had relatively more control over decision-making through formal mechanisms such as the voting assemblies, while the rest of the populus Romanus, that is, the plebs, exercised more power through demonstrations, secessions and riots. ${ }^{480}$ We continue with the analysis of demonstrations of displeasure and good will at contiones, legislative assemblies, elections, trials, games, triumphs, funerals, including miscellaneous expressions of favour towards popular champions. These were the venues for popular demonstrations during which the will of the plebs became manifest through cheers and jeers, and other forms of collective demonstration. The theatre witnessed occasional outbursts of hissing and jeering, applause and cheering as spectators showed their support of favourites and protested the presence of those whose policy or person they opposed. Cicero may have believed that shows were a good place to assess a man's popularity because the crowd was less easily

${ }^{480}$ Finley (1983: 91) suggests this in his chapter on popular participation. 
manipulated than in comitia and contiones (Sest. 115), but his self-serving examples are from the eve of his recall from exile in $57 \mathrm{BC}$, and conceal the usefulness of contiones. These informal meetings offered senators the best opportunity to assess the people's opinion on issues about to be put to the vote, and to assess their chances of a successful candidature at election time.

\section{CASE STUDY: CONTIONES}

It is often maintained that the people played only a passive part at contiones, for the presiding magistrate and those invited to speak by him (usually other senators) alone enjoyed the right to address those assembled, with the result that the meeting was more a stage-managed political demonstration than a free discussion of the issue at hand. ${ }^{481}$ For a contio to count as democratic, there is a belief that the meeting should influence political decision-making. But, since the speakers were mostly members of the top property classis, some hold that the meeting could not possibly be considered democratic: a humble Roman could not simply stand up and put forward his view. The debate in the contio was limited to those men the

${ }^{481}$ Lintott (1999b: 196); the contio was "the essential instrument in the hands of members of the elite seeking to create and objectify a "verdict of the Roman People" in the view of Morstein-Marx (2004: 158). The contio was "an instrument with which to create a symbolic manifestation of the Popular Will and to exert the pressure of an ostensible communal consensus." (ib. 172). 
presiding magistrate allowed to address the meeting; opposition was often excluded. "The contio was essentially an official platform for politicians to present themselves and their views to small, presumably influential audiences." 482

But this argument presupposes only one kind of participation at the contio itself, namely that of addressing the audience, followed by one kind of participation at the assembly, voting. Moreover, the implication is that those in attendance were wealthy members of rural tribes - the traditional "influential" element. As we saw in Chapter Two above, however, there is good reason to believe citizens with lower property qualifications had moved to Rome and their votes now formed the majority in many rural tribes, so that the extremely wealthy no longer dominated the legislative assemblies. Contrary to Vanderbroeck's suggestion that the audience at a contio was made up predominantly of artisans and shopkeepers, ${ }^{483}$ the nature of the issues debated in contiones indicate that a variable and mixed group of citizens was in attendence, mostly urban dwellers, including recent arrivals from the countryside. ${ }^{484}$ The populus that made up the forum crowd

\footnotetext{
482 Mouritsen (2002:46).

483 Vanderbroeck (1987).

484 Cicero (Leg. agr. 2.70) appeals to an urban audience, reluctant to give up the benefits of the city for a life of drudgery in the countryside. Gruen (1974: 387-404); Mouritsen (2001: 39-46); Morstein-Marx (2004: 130).
} 
included citizens from all walks of life: those who elected Cicero consul (i.e. members of centuries influential in the comitia centuriata, Leg. agr. 2.3); the plebs urbana (ib. 2.70); and the diverse members of candidates' and magistrates' entourages (adsectati), there to show support for their patrons (Comm. Pet. 34, 37-38). ${ }^{485}$ Also taking their ease in the forum were unemployed layabouts and busier folk such as freedmen (Comm. Pet. 29), shoppers and shopkeepers (themselves often freedmen). ${ }^{486}$

Another argument that reduces the popular influence at contiones suggests that elite manipulation and control over contional "debates" meant that, despite the "ingratiating rhetoric of popular power", the senate was firmly in control:

the contio served better as a communal arena in which the hierarchies both within the political elite and in the Commonwealth as a whole could be established, perpetuated, and validated than as a democratic forum for bringing to light, clarifying and pursuing the real interests of the voting citizens. ${ }^{487}$

\footnotetext{
485 As noted above in Chapter One, Morstein-Marx (1998: 260f.) has successfully defended the reliability of the Comment. Pet. While this pamphlet provides advice for electioneering, magistrates also maintained retinues once elected, both to stress their popularity in the competitive environment of Roman politics, and to protect themselves from physical intimidation.

486 Vanderbroeck (1987) emphasises the attendance of shopkeepers and artisans at the expense of the rest of the populace.

487 Morstein-Marx (2004: 285 f.).
} 
This argument rests on a perceived lack of success on the part of the people at achieving significant reform in its interest - the late Republic saw only limited relief in the areas of food supply and land redistribution, and none in relation to reform of the political system to make it more responsive to popular pressure, save for the introduction of the secret ballot in the 130s and the restoration of tribunician powers in 70 . While the pressing urgency of these small victories is acknowleged, they are downgraded to fit the thesis: Morstein-Marx disagrees with Millar's democratic interpretation of the political system, so puts a strong case against Millar's theory. MorsteinMarx's effort to state his own case results in his underemphasis of some significant democratic elements. In response to Millar's model of persuasion which claims that the elite had to appeal to popular ideology and meet fairly specific demands, Morstein-Marx suggests this ideology could be created and so controlled by orators. ${ }^{488}$ He in fact suggests that contiones were used more to mobilise than persuade, as illustrated by the case of the series of contiones held regarding the consular bill to establish a special court to try Clodius following the Bona Dea sacrilege. Here speakers mobilized support against the opposing faction. ${ }^{489}$ But is this not just semantics? A speaker still has to persuade someone to support them before

\footnotetext{
${ }^{488}$ Millar (1998: 217); Morstein-Marx (2004: 14-18). See Connolly (2007: Ch. 1) on persuasion, etc.

${ }^{489}$ Morstein-Marx (2004: 186-89).
} 
mobilisation occurs. And this process was likely often repeated with a different crowd each time.

As for the role of contional audiences, this is often described as rowdy support or disapproval of proposed laws and prospective magisterial candidates. Yet approval or disapproval of speakers did have an impact on decision-making, as witnessed by the effort put in by orators to secure the support of the audience. Cicero emphasises the importance of the popular element in the process of deciding land reform, when he challenges, then summons, Rullus to a contio and declares: "I wish to use the populus Romanus as arbitrator" (Leg. agr. 1.23).

A study of contiones reveals their importance and the role of popular approval of issues raised there: magistrates had to persuade the people that their policy or candidacy was worthy of support. It was in this environment that the citizens had the best opportunity to communicate with magistrates. 490

490 See Pina Polo $(1995 ; 1996)$ for the political role and significance of contiones. 
Contiones gave rogatores 491 the chance to test the water and ensure they had the support needed to pass their bill into law and so avoid the humiliation of failure.492 Contiones also provided a unique opportunity for those in Rome on the day of these informal public meetings to witness the debate, and show their support, or lack thereof, by cheering or booing. ${ }^{493}$ They were "a tool with which to create public opinion and popular pressure." 494 These meetings offered a chance for citizens to express a kind of freedom of speech, just as Rome was a kind of democracy.

Freedom of speech was a key component of men's libertas. ${ }^{495}$ Commoners were de iure permitted to address contiones but only if invited; in fact, they seldom did. Livy records one instance in 171 when the ex-centurion Sp. Ligustinus was invited by the consul and tribunes to talk about his military service (42.34). But the rarity of taking such an active role does not rule out

\footnotetext{
491 The term contionator "the speaker in a contio" is rarely used by Latin authors, and usually means "demagogue" (e.g. Cic. Cat. 4.9). Hence my use of rogator here, based on the usual practice of contiones being summoned by the magistrate or tribune proposer of the bill to be debated. Others also called contiones together, such as Cicero, to celebrate his election to the consulship, which happily handed him the opportunity to talk in opposition to Rullus' land bill.

492 Morstein-Marx (2004: 123-128, 160).

${ }^{493}$ On the role of popular acclamation during the Empire, see Aldrete (1999).

494 Pina Polo (1995: 216).

${ }^{495}$ See Chrissanthos (2004); Brunt (1988: 313-317, 327-329).
} 
the possibility of popular participation of another kind in these informal public meetings.

It is clear from our ancient sources that the members of the audience at contiones were able to communicate their opinion to the speakers. The tribunus plebis Macer expected an interjection in his speech urging the people to take action against the Sullan aristocracy when he said, "'What, therefore, do you propose?' one of you might interject" (Sall. Hist. 3.48.14M). Cicero acknowledges interaction with audience in the speech he delivered against the tribune Rullus in 63: "I see someone who confirms that the will was made" (2.41). Similarly, the crowd murmurs a response after Cicero roused those present with references to Rullus selling off land won by ancestors: “It seems to me your feelings are moved a little" (2.49). Again we see him trying to assess popular opinion via the contio in the third speech delivered against Rullus: “I see that certain of you indicate I don't know what by your rumbling" (strepitu, 3.2). One further example will suffice to illustrate the practice of orators fishing for a reaction from their audience at contiones. In his speech in defense of Sestius, Cicero attacks the praetor, Clodius' brother Ap. Claudius Pulcher, regarding the technique of putting questions to the contional audience in order to elicit a response (Sest. 126). There is no question that this technique was widely used to establish the will of the audience, despite Cicero's efforts to reduce Appius' case to the meaningless 
response of "half-dead hirelings" (ib.). ${ }^{496}$ We need to be wary of Cicero's criticism of the praetor's technique for two reasons: first he criticises Appius for putting the question of Cicero's return to a contio rather than to the traditional comitia, then he accuses him of loading the meeting with mercennarii. We must question the basis of these complaints: the centuriate assembly would vote on Cicero's recall, but he is playing with his audience when he claims the comitia was the ancestors' venue for debate; the contio had long been used for this purpose. As for pin-pointing the source of the outcry to hirelings - such precision would have been impossible without modern surveillance equipment. Cicero understandably targeted Appius because he opposed the exile's recall. The orator provides additional evidence himself to make us question his reliability as a source for the nature of contiones: he hypocritically denigrates these informal assemblies as being at the beck and call of masters loathed by the populus Romanus (Sest. 127), yet, as we have seen above, he himself had been dominus when he addressed a contio in 63 and successfully deterred the people from voting in favour of Rullus' land bill.

Despite clear efforts to register the response of audiences, it has been held that Cicero shuns such interaction, that "actual audience responses are

496 Morstein-Marx (2004: 121) notes Cicero's hypocrisy. 
mentioned only as something to be avoided". 497 This belief is based on a misinterpretation of a passage from Cicero's treatise de Oratore (2.339), in which he advises orators to avoid hostile responses caused by error (peccatum), annoyance (offensio) or dislike (invidia), unpopular subjects or an agitated audience. The problem is the substitution of hostile for all responses, including secunda. The scholar in question may have overlooked adversa as the avoidance of all responses reinforces his theory that "in Cicero's ideal model of contional speech, communicative influence goes only one way, from elite speaker to mass." 498 To the contrary, Cicero's orator responds to acclamatio (shouts). What Cicero suggests is how to deal with hostile shouts (acclamatio adversa), and in so doing he implies not that they were to be avoided, but were inevitable given the preconditions he listed. Also, Cicero says nothing on the topic of acclamatio secunda - something to be sought out perhaps? Indeed Morstein-Marx acknowledges Cicero's double standards: the consummate orator himself does not practice what he preaches when he adopts the techniques of populares to stir up the crowd (when his theory recommends calming) and use of the call-and-response technique. ${ }^{499}$

\footnotetext{
497 Morstein-Marx (2004: 65).

498 Morstein-Marx (2004: 65).

499 Morstein-Marx (2004: 66).
} 
Morstein-Marx further argues that orators were ventriloquists who made the crowd say something useful: "favourable audience responses are almost always prompted by the politicians themselves" 500 No true crowd response was recorded: any response from the crowd contained in Cicero's speeches was elicited by Cicero using cunning rhetorical techniques (e.g. claptraps to elicit applause, the tricolon, and antithesis). ${ }^{501}$ This strikes me as an ingenuous line to take as it negates the possibility that members of the contional crowd expressed their own opinion. Morstein-Marx creates a law binding on all occasions, and so portrays the people as incapable of independent action. It is not in the interest of objectivity to take such an absolute approach to an area of social history in which the sources are so partisan. But we can see why he has not supported (or even examined?) the other side of the argument: not only is the evidence slim regarding the existence of independent crowd participation in informal assemblies, but by taking the line that senators like Cicero manipulated opinion he supports his own overarching thesis that the governing elite manipulated the people. Still, he ought at least to deal with the very real possibility that Cicero was not responsible for every shout or clap, and that the orator was in fact recording audience response as it happened. Morstein-Marx only goes so far as to acknowledge that sources other than Cicero hint at such a reality in

\footnotetext{
${ }^{500}$ Morstein-Marx (2004: 136 n. 92).

501 Morstein-Marx (2004: 136-143).
} 
the form of contradictory crowd responses - he finds himself in the precarious position of dealing with evidence that contradicts his neat theory that speakers controlled their audience. How can this be if the crowd's reactions differ? He puts the phenomenon down to "the natural variations of responsiveness within a crowd"502 - but where does he make it cohere with his other claim that politicians prompted the shouts? Are there then several puppet masters motivating crowd behaviour and reactions?

Cicero used contiones to gauge popular opinion, as he makes clear in a letter to Atticus written March 15, $60 \mathrm{BC}$ :

Tribune Flavius is vigorously pushing his agrarian law with Pompey's backing. There is nothing popular about it except its mover. With the approval of the contio I advocated the deletion from the bill of all provisions detrimental to private interests (Att.1.19.4).

How did he evaluate the popular will? As above, he directed questions at the audience and measured the level of support from their response. The orator also utilised his considerable powers of persuasion, demanding "the plebes Romana at least be able to consider what its interest is (quid intersit sua), what is to its advantage (quid expediat), and how much confidence it thinks ought to be given to you in the purchase and sale of things"' (Leg. agr. 2.66). His tactic of siding with his audience was not novel - others had

502 Morstein-Marx (2004: 146). 
painted themselves in popularis colours to win the support of the people, which means there was at least this ideal that the senate ought to defend the popular interest. And the contio was one of the most important venues for assessing the commoda plebis.

Cicero had summoned the contio himself, so no doubt he was preaching to the converted, although it must be remembered that the forum was a public space, so other interested parties could attend these meetings. He sought to "manipulate public opinion in those quarters which mattered to Cicero, that is the boni or propertied classes, alerting them to the ominious threats of Rullus' seemingly moderate bill." 503 He may also have been targeting tribunes with his words of doom, as it was they who were able to use their veto to block their fellow tribune's proposal. It is likely that he valued the views of the lower strata of society also, a reflection of the competitive nature of Roman politics as one politician had to compete with the rest to win support from every level of society in order to enhance his auctoritas, a competition made even more difficult by the lack of political parties. The effort to win the support of these more humble members of society indicates the voting clout of the plebs: their backing was crucial to get bills passed

503 Mouritsen (2001: 55). 
into law. ${ }^{504}$ The use of the contio as an index of popular support would have been redundant if the people's support did not translate into votes.

Another method employed by contional audiences to communicate with speakers was the shouting of slogans. We have evidence that Clodius used claquers to abuse Hortensius and Curio with slogans at a contio on the topic of Cicero's exile (Dio 38.16.5). This has been viewed as a deterioration of discipline typical of the late Republic ${ }^{505}$ - but vocalisation of opinions was surely a common method in an oral society with few other communication options. The positive publicity generated by a successful contional speech went a long way: soundbites, slogans and published speeches circulated far and wide, reaching the municipales. ${ }^{506}$ Morstein-Marx has referred to this as the "bandwagon effect": a successful contio deterred opponents from voting, so that only a favourable populus assembled.507 There does not, however, seem to be anything preventing the organisation of a rival contio, especially when we take into account the small number of voters needed to

\footnotetext{
504 Morstein-Marx (2004: 122 ff.).

505 Taylor (1966: 28).

506 Millar (1998: 29, 126, 145, 195). In a similar vein, Gregory (1994: 93) analyses the writing of graffiti and slogans as a means of communication between the plebs and politicians. He suggests that such messages written on statues or portraits might indicate the "reappropriation" of the power these images are designed to have over the spectator, revealing "a degree of political and ideological awareness amongst the urban 'mob'."

507 Morstein-Marx (2004: 185f.).
} 
be mobilised by opponents. ${ }^{508}$ Moreover, Morstein-Marx discounts as inconsequential the debate that did arise at the contiones preceding the vote on the Gabinian, Manilian and Trebonian laws, on which see below.

Contiones offered the orator the opportunity to measure the mood of the multitudo. In 63, Caesar persuaded the tribune Labienus to prosecute Rabirius for his involvement in the murder of Saturninus following the SCU in 100. The case was tried before the centuriate assembly but the vote was never taken.509 A criminal conviction might have resulted had the praetor Q. Metellus Celer not raised a red flag on the Janiculum and so dispersed the preliminary contio. For Cicero's inflammatory remarks (he called Saturninus a hostis populi Romani) resulted in public protest in the form of shouting at the contio (Rab. Perd. 18). Thus we see fear of popular reaction influencing the actions of the aristocracy.

It will pay to analyse the findings of Vanderbroeck's study. Vanderbroeck investigates 24 possible and confirmed incidents of collective action at contiones between the activities of the tribune Quinctius following the

\footnotetext{
508 Riggsby (2005).

509 On the sequence of the prosecution, see Tyrrell (1973: 292).
} 
conviction of Oppianicus in 74 and the tribune Ateius summoning a group of people to prevent Crassus' departure for Parthia in 55 BC. 510

We examined the tribunate of Quinctius in Chapter Four above, in relation to his efforts to restore tribunician powers. While he was unsuccessful in this aim, he did succeed in organising daily contiones at which he roused his audience with claims of senatorial injustice. Cicero criticises the tribune for his attacks on the senatorial court and, in particular, the presiding magistrate Junius for accepting bribes after the trial of Oppianicus in $74 \mathrm{BC}$ (Cluent. 77, 89 ff.). Cicero is particularly unimpressed by Quinctius' use of public space and creation of uproar and noise:

How come my case is being heard in such deep silence now, whereas Junius then was deprived even of the chance of defending himself? The reason is that then the case was wholly at the mercy of prejudice, misunderstanding, suspicion, and the spirit of lawlessness and tumult which daily animated the mass meetings (invidiam, errorem, suspicionem, contiones cotidianas seditiose ac populariter concitatas). The accuser was a tribune of the people: whether on the platform or before the people, a tribune still (idem in contionibus, idem ad subsellia); and he came into court straight from his mass meeting - or rather, he brought it with him (ad iudicium non modo de contione, sed etiam cum ipsa contione veniebat). The Aurelian steps over there - they were new then - might have been built to serve as an auditorium for the case: and when the accuser had filled them with an excited crowd (concitatis hominibus), there was no possibility of speaking for the accused; nor even of rising to speak (Cluent. 93).

510 Contiones in fact constitute the largest single category of collective action in Vanderbroeck's (1987) study. 
Cicero contrasts his serene audience with that of Quinctius eight years earlier, omitting to mention that times had changed: no longer were tribunes operating on reduced powers, nor was senatorial corruption the problem it was in the 70s. For not only did Quinctius adopt a different style of oratory to Cicero, simultaneously praised as gravis and condemned as vehemens (Cluent. 77), 511 the tribune also had a far more passionate audience, fired up to bring an end to senatorial dominance of juries. ${ }^{512}$ Their enthusiasm is attested by their attendance at daily contiones. The constitution of this great crowd that filled the Aurelian steps is left undefined - all we know is that they were excited (concitati homines). We do not know whether Quinctius attracted plebs, freedmen, equestrians, or senators. Although we do know at least one senator was present: Cicero.

The populus Romanus gathered at a contio greeted Pompey's promise as consul-designate to restore tribunician powers with strepitus et grata admurmuratio and his assurance to deal with the law courts "non cum strepitu sed maximo clamore" (Cic. Verr. 1.45). In this way Pompey knew he had the backing of a wide cross section of the people, not just humble poor folk, for

\footnotetext{
511 Quinctius is also praised begrudgingly by Cicero for his ability to work up resentment against the judge and jury: "with all the authority of his office and all his skill at kindling the passions of the crowd" (Cluent. 79).

512 Cicero does acknowledge that the senatorial courts had a poor reputation with the people (Cluent.77) , but my point is that he does not take this into account in his criticism of Quinctius.
} 
Cicero was always quick to use derogatory terminology to describe a crowd of citizens if the opportunity presented itself.

The tribune Gabinius used a contio to make sure he had popular support for his proposal to appoint an ex-consul to lead a force against the pirates who were causing havoc with the grain supply. Morstein-Marx sees this as an example of elite manipulation in action: in the process of ascertaining the public will, the elite could also fashion it. ${ }^{513}$ And yet he concedes that "oratorical control over the audience and communication-situation may well be in part a hegemonic fiction shared by the political elite", with invidia (which he translates as "popular indignation") checking senatorial predominance. 514

The response of the audience at Gabinius' contio illustrates the power of invidia. The tribune had first taken the bill to the senate, and when he experienced resistance there, Gabinius reported the result to the people. They took umbrage at the rejection of what was clearly marked out as a job for their champion Pompey, so attacked the senate house, forcing senators to flee (Dio 36.23-24; Plut. Pomp. 25.1-4; Cic. Imp. Pomp. 44). Those of the people involved were, depending on the author, the universus populus

513 Morstein-Marx (2004: 18ff.).

514 Morstein-Marx (2004: 66f.). 
Romanus (Cic.), the more humble homilos and polloi (Dio), and the demos and plethos (Plut.). There seems to be a pattern developing here: when Cicero describes audiences associated with Pompey, they are not the plebs or multitudo but the more respectable populus. Cicero's choice of the word populus, the term that captures all Roman citizens unless opposed to senatus, 515 may reflect Pompey's widespread support by the various strata of society, or the word choice may be attributed to Ciceronian sycophancy in an effort to win over his hero Pompey.

Gabinius' first contio was followed some three weeks later by a second at which he invited Pompey to address the audience first (Dio 36.24.5-26). Gabinius spoke second and reinforced Pompey's words to the Quirites, encouraging them to choose what would benefit the state (Dio 36.26.27-29). The tribune Trebellius tried to speak in opposition but was not granted permission to speak, so interposed his veto. Gabinius responded by introducing a new motion that Trebellius be deposed as he was unfit to hold the office of tribune. The popular will prevailed; for after seventeen tribes voted to depose him, Trebellius withdrew his veto (Dio 36.30.1-2; Asc. 72C). The plebs came very close to deposing yet another tribune for obstructing their will. When a second tribune, Roscius, silently raised to fingers to indicate that two men should be appointed, the audience (homilos) disagreed

515 See Chapter One above on terms for the people. 
with such a great threatening shout that he desisted (Dio 36.30.3; Plut. Pomp. 25). With the opposing tribunes silenced hand and mouth, Gabinius invited the princeps senatus Catulus to speak (Dio 36.30.4-36; Plut. Pomp. 25). The contio broke up into the voting units of the concilium plebis to decide the fate of the bill. And so the law was passed with wide popular support (Dio 36.37.1). Again, without the testimony of Cicero, the Greek sources depict the participants at the contio as mean: demos, homilos (Dio), and ochlos (Plut.).

The case of the lex Cornelia de legum solutionibus also illustrates the strength of popular invidia in the face of senatorial obstruction. The tribune Cornelius promulgated a bill providing that senators could not grant office to anyone unless as prescribed by law, nor could they usurp the decision of the people in any other way. The senate reacted against this reduction in its auctoritas and encouraged one of the other tribunes to use his veto. This tribune, P. Servilius Globulus, also stopped the herald from reading the bill to the contio, at which point Cornelius read it himself. The populus greeted with a huge outcry the consul Piso's protest that Cornelius was ignoring Globulus' veto, and the consul's fasces were smashed when he ordered his lictors to arrest those threatening him. In the end a compromise was reached so that senatorial decrees granting dispensation could only be passed with a quorum of 200 senators present. (Asc. 58-59C; Dio 36.39.240.1). This case also hints that different elements made up the audience: 
while those up the front were destroying Piso's fasces, a group from the back were pelting him with stones (ex ultima contione, Asc. 59C). Not everyone in the audience was involved in the violence. Furthermore, there were clearly opposing sides, supporters of Cornelius versus those of Piso, which throws doubt on Morstein-Marx's "bandwagon effect" theory, according to which rogatores ensured that there was no debate at the contio preceding the vote (Dio 36.39.4). That the bandwagon effect failed is evidenced by the lack of consensus in this case. ${ }^{516}$

During the tribunate of Clodius in 58 several contiones are recorded as being held. Clodius further adapted the contio by using local organisations to arrange support for his proposals. The ancient evidence suggests that "the post-Sullan era witnessed the development of new methods of organizing the plebs and articulating social protest." 517 What had changed? Clodius was more effective in rallying support amongst the plebs urbana than any previous tribune had been: Vanderbroeck has him supplying the top leadership for some 25 incidents between 61 and 52 BC. But was the success a result of innovative techniques such as using intermediate leaders ${ }^{518}$ or the altered political circumstances? In the last generation Romans had

\footnotetext{
516 Morstein-Marx (2004: 185). See also above for Riggsby's criticism.

517 Nippel (1995: 70).

518 As suggested by Vanderbroeck (1987: 52 ff.).
} 
witnessed the rise of the military giant, an increasingly internecine nobility, and the expression of a new public clientele incorporating especially freedmen's interests. Clodius' method was to set himself up as the champion of the people and to attack Cicero; Clodius defended the liberty of the Roman citizen, as when he dealt with the infringement upon the People's liberty resulting from the ban on collegia. Nippel states that this ban, along with that of the Compitalian Games celebrating the abolition of the boundary between slave and free (which had also been banned after disturbances), "aroused the plebs's indignation". ${ }^{519}$ Clodius harnessed this invidia to gain support for the vote to repeal the ban on collegia - he certainly staged the games three days before the vote, assisted by a magister vicorum Sextus Clodius (Cic. Pis. 9).

Clodius succeeded in forming such a strong alliance with the plebs urbana that following his death in 52 the men who took his place as leaders of the Clodian faction "were able to channel the spontaneous anger of the populace as well as deliberately mobilize parts of the plebs for organized demonstrations, [the result of] Clodius' policy of organizing and, so to speak, training the plebs urbana." 520

\footnotetext{
519 Nippel (1995: 72).

520 Nippel (1995: 78). See also Lintott and Vanderbroeck.
} 
During the last one hundred years of the Republic, the audience at contiones changed, as popularis politicians made increased efforts to invite their supporters to attend, thus altering the composition of the traditional contional crowd of boni. With such ideologically opposed groups of supporters, debate in the forum resembled party politics, as one faction tried to appeal to the supporters of the other, as when Cicero played his popularis card. ${ }^{521}$ Those men addressing contiones naturally responded to their audiences, who participated in this important part of the decision-making process by shouting their approval or disapproval, and by more physical demonstrations of their opinion.

\section{CASE STUDY: LEGISLATIVE ASSEMBLIES}

The populus Romanus had another avenue of communication with politicians: the people could also participate in the decision-making process via the legislative assemblies. ${ }^{522}$ The Roman populus is special in the history of the crowd, for its means of expression was not limited to demonstrations; the Roman people was the legislative body. The only other well

\footnotetext{
${ }^{521}$ Mouritsen (2001: 62).

522 On the formal aspects of these assemblies, see Chapter Two above.
} 
documented instance of such direct democracy in antiquity, in terms of influence on decision-making, is that of fifth century Athens.

Citizens in their capacity as voters indicated their support for a man and his treatment of the issue at hand by voting in favour of the bill. In most cases it is difficult to distinguish whether the bill is voted into law due to the popularity of the rogator or the issue. Patronage still counted to a certain degree: a patron could rely on his client to support or oppose a bill, if he shared the opinion of his patron either from personal conviction or from being won over by the patron. But there was no method for a patron to confirm the way his client voted once the secret ballot was introduced for use in legislative assemblies in 131 BC. Clients could vote as they pleased. Thus patronage had less influence on decision-making than traditionally put forward by old school classicists. ${ }^{223}$

I have examined the nature of formal popular participation in legislative assemblies above in Chapter Two. These assemblies also gave the populus Romanus, plethos, demos, operae, manus, senators, equestrians, soldiers, libertini and servi the opportunity to have an informal influence on decision-making through demonstrations.

${ }^{523}$ See for instance Münzer (1920) and the articles collected in Wallace-Hadrill (1989). 
Legislation involved the conflicting interests of many groups. These different factions clashed in the forum, Campus Martius and streets of Rome. Negotiation and concession sometimes prevented the groups from coming to blows. At other times, violence was avoided by a superior show of strength, sufficient to scare off the opposition.

In the first case, we see the interests of three clash: divisores, agents officially charged with the duty of distributing largess by tribe, came into conflict with a reforming tribune and a conservative consul. In $67 \mathrm{BC}$ the tribune Cornelius proposed a lex de ambitu in an attempt to curb electoral corruption. The homilos adopted the bill (Dio 36.38.4). According to Asconius (74C), the tribune convinced the populus Romanus that there was such dire need for the law that they clamoured for it. But then the senate worried that the severe punishments would deter people from accusing those who broke the law due to the "desperate danger" this would place the accused in. The opposing senators then broke two laws in an effort to reform Cornelius' law: they voted to introduce the law in the period before the elections during which no law was to be enacted, and they usurped the people's right to pass measures legally binding on all Romans. The consuls Acilius and Piso redrafted the bill to mitigate the severe penalties of Cornelius' measure so that those found guilty de ambitu were fined, banned from holding office and ejected from the senate (Dio 36.38.1). But this time 
they included penalties for divisores. At this, a multitudo divisorum attacked the assembly. Piso countered the violence of these agents with a greater armed gang (maior manus) of his own, and in this way he secured the passage of the law (Asc. 75-76C). In the end, the conservative element triumphed but not before experiencing a fierce demonstration of popular opinion, in which divisores expressed their dissatisfaction at inclusion in the bill. And not without adopting in response the methods of the populares in the form of reliance on a manus. Cicero meanwhile exaggerates the extent of the people's defeat: “They say that because of the recklessness of that tribunus plebis you can be induced to surrender all claim to that power" (Asc. 76C). They may have had a law they passed overturned by the senate, but the end of 67 , the plebs were once more flexing their decision-making muscle.

In the next example, the tribune Manilius' lex de libertinorum suffragiis reads differently depending on the source. From Dio (36.42.1-43.2), we get the impression Manilius backed a bad horse, misjudging the popular interest when on the last day of $67 \mathrm{BC}$, he summoned an assembly and persuaded tines ek tou homilou to support his proposal to enrol freedmen in rural tribes as well as urban, and so spread their vote over all tribes. The majority of the plethos opposed the measure, however, and it was annuled by the senate the next day. It was after this falling out with the freeborn citizens that Manilius 
sought to rekindle their affection by proposing Pompey be given command against Mithridates. Cicero paints a much bleaker picture, alleging Manilius organised a band (manus) of freedmen and slaves to support his bill (Asc. 45C). He deliberately besmirches the status of freedmen in the audience to exaggerate the tribune's demagogic characteristics. Freedmen naturally made up a significant proportion of all forum audiences as it was these men who owned and worked in the tabernae around the city centre. Asconius (65C) notes that the law was proposed during the period of the Compitalian festival, organised by the collegia compitalicia. Vanderbroeck suggests that Manilius took advantage of this event and sought the assistance of magistri vicorum, who presided over the collegia, to organise the manus. 524

In the previous example we saw a popularis politician charged with organising manus libertinorum et servorum (Asc. 45C). In the following case involving Clodius, Piso and the Lex Pupia Valeria de incestu, the charge is more serious, the use of operae or "gangs" against a concursus of boni and optimates. In $61 \mathrm{BC}$ the optimates (dunatoi) forced the consul Pupius Piso to propose a bill to set up a criminal court to try Clodius for sacrilege following the Bona Dea scandal, and for committing incest with his sister (Cic. Att. 1.13.3). Cicero's account describes the occasion in detail, picking out in the

524 Vanderbroeck (1987: 227). 
assembly trouble-making barbatuli iuvenes and totus ille grex Catilinae under the leadership of Curio who begged the populus to vote against the bill. The consul Piso also talked against the bill he had unwillingly proposed. Then when it came time to vote, Cicero saw operae Clodianae occupying the bridges and reports that the tabellae handed out included no "ayes". Cato, Hortensius and other of the boni ran together to address the comitia (Att. 1.14.5). In the end the bill was passed, but only after deleting the clause stipulating the jury be appointed rather than the usual selection by lot (Cic. Att. 1.14.1-2; 1.16.2). Clodius was acquitted after bribing the jury (Dio 37.46.1-2). In this case, Clodius enjoyed the widespread support of iuvenes, Catilinarians and his own supporters, termed operae by his enemy Cicero. We see also Curio pleading with the populus to vote against the bill that would have set up the special court to try Clodius. The combination of Curio's oratory convincing the voters to reject the bill and the brute force of the supporters who blocked the voting bridges resulted in the optimates dissolving the assembly and reworking the bill to give it more widespread appeal. Popular opinion struck another blow against optimate domination, even if it reflected the will of popularis leaders.

The people were again organised into gangs, or less pejoratively and more accurately bands, to give strength to their opinion on the Lex Julia agraria in 59 BC. Caesar had been compelled to form a private amicitia with Crassus 
and Pompey after experiencing the intransigence of the conservative element of the senate under the leadership of Cato. Appian provides the narrative, with details fleshed out by Plutarch, Cicero and Cassius Dio. To ensure the passage of his bill, Caesar secretly organised a large band of men (cheir) to back him should he need, then took his proposal to the senate, where he found little support so abandoned the senate for the rest of the year and instead addressed the people from the rostra. In one of these contiones he asked Pompey and Crassus if they supported his bill, and when they expressed approval the demos came to the voting place with concealed daggers (App. BC 2.10). The senate convinced Caesar's colleague Bibulus to oppose the bill, but he was attacked and his fasces broken when he interrupted Caesar's contio. Cato was also ejected also when he tried to make a speech criticising Caesar. With the optimate opposition disposed of, the bill was passed into law (App. BC 2.11). Pompey helped his ally by sending soldiers into the city to vote (Plut. Caes. 14.6). The populares were well organised, so that the plebs occupied the forum the night before the legislative assembly (Dio 38.6.1-4) and Vatinius and C. Fibulus led them in an attack on the consul Bibulus when he tried to obstruct proceedings (Cic. Vat. 22 and 31). Cicero appears outraged at this attack on the consul, yet his own rhetoric belies the illegal actions of Bibulus: he was not summoned to address Caesar's contio so was rightly ejected to prevent his obstructionist tactics, and no one was permitted to enter the curia since Caesar did not 
summon the senate for the rest of the year. The Caesarians may have overstepped the mark, however, when they sent a lictor to drag him from his house, unless the implication was that Bibulus' actions had made him a public enemy (hostis). But Clodius had not yet passed his law rendering illegal obnunciation, so Bibulus ought to have been within his rights, though the legality of his obstruction is by no means clear in Dio (38.6.4-6). Cato Minor also tried to get in the way, but was removed from the forum twice by the Caesarians (Dio 38.3). The plebs were well within their rights to eject from the rostra those not invited to speak, in this case Bibulus and Cato, although it is not clear from the sources whether Cato was in fact summoned to address the contio. He found no favour with the audience, however, and was twice made to leave. In this way the plebs, variously termed plethos and demos in the Greek sources, made clear their intentions to vote in favour of a bill that served their interests.

During his consulship in $63 \mathrm{BC}$, Cicero had broken the law and executed Roman citizens without a trial. While he had his excuse that they were not citizens but hostes since they had attacked the state, his actions nonetheless supplied his own enemies with ammunition. Moreover, if we lay partisan politics aside for a moment and consider the popular point of view on these executions, a picture emerges of a people fearful of the reassertion of the arbitrary use of magisterial power to repress the rights of the people, in this 
case to a trial on capital charges. Dio (37.38.1-2) portrays the reaction of the polloi in this way: they are angry at Cicero for causing the death of citizens and feel additional hatred for his taking liberties with the oath delivered on his final day of office, in which he praised himself for saving the state despite being forbidden to do so. It is in this light that we ought to consider the following case, that of the Lex Clodia de exsilio Ciceronis.

Dio (38.12.5-7) records Cicero's unpopularity amongst the great numbers who were annoyed by his speeches (deemed too frank and condescending) and amongst the enemies he made by trying to outdo even the most powerful men. Clodius hoped to win over senate, equestrians and homilos easily, and so crush the braggart. With this purpose in mind he went about buttering up the needy with free corn, the freedmen and artisans with the revival of collegia and the elite with a ban on revision of membership to the senate by censors (Dio 38.13.1-2). ${ }^{525}$ Clodius first passed a lex de capite civis, which everyone understood to be directed against Cicero although it did not mention him by name. Although all the senate shared the responsibility since they had charged the consuls with seeing to it that the state suffered no harm, it was Cicero who had exacted the penalty against the

\footnotetext{
525 It is not clear how any of these measures might have won over the equites. Cicero may have enjoyed their support already as a member of that order and a homo novus - they certainly went into bat for him when they sent envoys to consuls and senate on his behalf (Dio 38.16.2).
} 
Catilinarians, so he received most of the blame (Dio 38.14.4-6). When Cicero lost his nerve after not receiving the support of Caesar and Pompey that he expected, he went into voluntary exile, at which point Clodius persuaded the people to pass a law exiling Cicero by name (Dio 38.17.7). Cicero's own account paints quite a different picture, as we might expect. Clodius is not defending the rights of citizens, but targeting Cicero, robbing him, an exconsul, of his citizenship by the mere summoning of a concilium, and by gathering gangs of the needy (egentes) and servi (Cic. Dom. 79). If we scrape away the bitter hostile bias, we can recognise some of those who participated in the vote to legalise Cicero's exile from Dio's account: the needy were those whom Clodius appealed to with his food bill, and the servi more likely libertini who benefitted for the revival of collegia.526 To be sure, Clodius' desire to exile Cicero may have been motivated by personal malice, but equally Cicero had mistaken the will of the poor and the freedmen, and no doubt others from the lower orders who were wary of a consul who did not consult them before executing Roman citizens. And for this oversight and insensitivity to popular opinion, he paid with seventeen months exile. Cicero's rhetorical abilities were unable to persuade the people to spare him.

526 Vanderbroeck (1987: 243) suggests freedmen rather than slaves participated, but provides no reason for his theory. 
In January $57 \mathrm{BC}$, the tribune Fabricius tried to pass a bill securing Cicero's recall. Despite occupying the rostra the night before the tribal assembly, his attempt failed when he came to blows with those who opposed Cicero's recall. This was no gang of ruffians as Cicero alleges, but powerful men including the consul Metellus Nepos, Clodius and his brother the praetor Ap. Claudius. These certainly did not take on Fabricius and his gang alone, but brought along their armed clients, including slaves, to protect them these armati homines et servi do not escape Cicero's notice (Sest. 75) whereas he omits to mention that Fabricius relied also on armed supporters, which of course he did or else he would have stood no chance. Cicero deliberately downplays any questionable behaviour by those on his own side. The scene as portrayed by Cicero resembles a blood bath, with his supporters being driven off or slaughtered, the centre piece his own brother having to cover himself with the corpses of slaves and freedmen to save his life (Sest. 76). Dio, on the other hand, emphasises the responsibility of both sides (39.7.1). Fabricius' bill failed thanks to popular support in favour of Clodius and his faction.

This demonstration of popular strength forced Cicero's side to put the matter of his recall to the comitia centuriata, reviving a seldom used practice of referring matters concerning a citizen's life to the centuriate assembly the assembly traditionally dominated by those who owned land. Cicero 
emphasises the efforts of Pompey, who sent his men to mobilise the populus Romanus, especially the municipii and coloniae of the Italian countryside, to come to Rome to vote. He also praises the consul Cornelius Lentulus Spinther, who summoned the assembly (Cic. Att. 4.1.4, Dom. 75 and 90, Mil. 38f., Pis. 80; App. BC. 2.16; Liv. 104). Cicero did not have the support of the masses, hence the decision to take the vote for his recall to the comitia centuriata - his backers had given up on winning popular support. Dio is therefore mistaken when he claims the plethos backed Cicero's recall (39.8.23). The exile's supporters were ultimately compelled to move the vote to the comitia centuriata to avoid the wrath of the common people in the assembly weighted in their favour, the concilium plebis. Clodius had won the plebs over as he better understood their needs. The case of Cicero's recall also emphasises the importance of having the plebs on side for the passage of bills via the concilium plebis. Without the voting clout of the city's inhabitants, a bill was unlikely to be passed into law.

Yet Cicero's is a special case. When we reflect upon the typical forms of participation in legislative assemblies, popular demonstrations provide evidence for informal methods of influencing the decision-making process.

CASE STUDY: TRIALS 
At trials too the people had plenty of opportunity to have their opinions heard outside the formal role they had on juries. Jury service was usually the prerogative of the wealthy senatorial and equestrian orders, but in $70 \mathrm{BC}$ a lex Aurelia added jurors from another order. ${ }^{527}$ These were the tribuni aerarii, a mysterious group of men, nowhere in our ancient sources formally defined. They may have been from the same order as equestrians, or a lower one. Dio (43.25.2) refers to them as part of the plebs when he notes that Caesar deprived them of their role as iudices at quaestiones in $45 \mathrm{BC}$.

Trials are sometimes criticised for being nothing more than stages on which the aristocracy worked out their differences, ${ }^{528}$ yet important issues such as the food supply and popular rights were also addressed at these trials; popular participation occurred when rights were challenged.529 Thus, trials were not only a competition over dignitas, although many involved charges of electoral corruption as members of the elite struggled to win office and so honor. Ambitus was a charge levelled at candidates for curule offices who got carried away with canvassing, whereas the charge of maiestas was more often levelled at ex-tribunes who had taken on the conservative element in

\footnotetext{
527 Gruen (1974: 45 f.), Taylor (1960: 149); Scullard (1959: 95, 419); Wiseman (1970: 71 f., 79 f.). 528 See, for instance, Lintott (2004: 62) on politically motivated prosecutors. 529 See below on Milo's trial in 56 BC and Cornelius' in 66.
} 
the senate, often in defense of popular rights. Senators finding themselves charged with these offences looked to their supporters for assistance. In the following cases the popular response is examined.

The people's involvement in the trial of P. Autronius Paetus was limited to a violent display of opposition to his being charged de ambitu. Autronius was in 66 on trial for electoral corruption after securing his election to the consulship of 65. Cicero, in his defence of Autronius' colleague P. Cornelius Sulla, sought to paint Autronius in a dark light to emphasise the innocence of his client in comparison; for this reason he alleges Autronius first recruited gladiatores and fugitivi to disrupt his trial, then used unnamed men to throw stones and riot (Cic. Sull. 15). It must be noted, however, that Sulla was also convicted (Sall. Cat. 18.2; Asc. 75 and 88 C; Dio 36.44.3, 37.25.3), even though he was a much more amicable man - Autronius had terrible temper and other negative traits which made him easy to dislike (Cic. Sull. 71). ${ }^{530}$ His later involvement in the Catilinarian conspiracy (Suet. Jul. 9) implies Autronius was a man desperate to form amicitiae in the face of a hostile and entrenched aristocracy. Due to these difficulties in winning the acceptance of the boni, he turned to those clients he could, and used hired gladiators and slaves. But two points need to be made in relation to the

530 Gruen (1974: 441) calls him "bitter and explosive by nature" and notes that all Autronius achieved by organising such disruption was the hastening of his own conviction; Lintott (1968: 212) focuses briefly on the existence of violence during the proceedings. 
constitution of the crowd who demonstrated their support for Autronius: others before him had relied on gladiators and slaves for protection; and Cicero omits the free citizen clients who without a doubt came to his aid, highlighting instead the servile element in order to undermine Autronius' integrity and so bolster that of his client, Sulla. With Cicero's bias taken into account, and the use of slaves placed in context, we see the participation of Autronius' supporters in a different light: these were men demonstrating their frustration at having their elected candidate removed from office.

In the same year we see a very different group of the people take centre stage at a trial. C. Cornelius was charged with treason (maiestas) following his conduct in defence of popular rights during assemblies while tribune in 67,531 but the charge was dropped when noti operarum duces challenged the prosecutors, the brothers Cominii, as they stood on the tribunal (Asc. 5960C). Cornelius had been a popular tribune, preventing his consular and conservative enemies from usurping the people's right to decide who was granted office (Dio 36.39). ${ }^{532}$ The intervention of noti operarum duces provides an example of leadership originating from outside the aristocracy. The sources mention no link between Cornelius and these well-known leaders of bands of men, although the connection has been supposed by

\footnotetext{
531 On which see above, with Asc. 57-81C and Dio 36.38-40.

532 Gruen (1974: 438); Lintott (1968: 212).
} 
modern commentators. ${ }^{53}$ If there is no evidence that Cornelius organised the duces to intervene on his behalf, we might suggest that these unnamed noti duces acted on their own initiative to mobilise Cornelius' supporters. Public demonstrations such as this one at Cornelius' trial, then, present the possibility that there was a democratic element to popular protest at trials, whereby citizens outside the elite strata organised demonstrations.

Duces operarum appear on the scene again in the following year. Manilius was taken to court charged with treason and, like Cornelius before him, turned to operarum duces for assistance (Asc. 60 and 66C). ${ }^{534}$ The people (homilos or demos) showed Cicero not only that they were ardent supporters of Pompey and his adherents, but that they were familiar with the law when, at the end of his praetorship in 66, Cicero failed to give Manilius the statutory ten days to prepare his defense on a charge of extortion (Plut. Cic. 9.4-6; Dio 36.44.1-2). The praetor's excuse was that he wanted to preside over Manilius' trial himself before his office ended and a less friendly praetor took over. The tribuni plebis were not convinced of his altruism and summoned Cicero to explain himself to the people at a contio. Cicero did

533 Vanderbroeck (1987: 228), for instance, implies Cornelius organised them to come to his aid.

${ }^{534}$ Gruen (1974: 262, 441); Lintott (1968: 212). Vanderbroeck (1987: 229) is critical of Gruen's suggestion that Domitius Ahenobarbus brought the demonstration to an end because he bases his claim on the Scholia Bobbiensia, which he considers too unreliable as a source of evidence. 
well to recover from his original misjudgement of popular opinion and, praising Pompey to the skies, in turn received popular praise, with the audience even going so far as to request that he defend Manilius (Asc. 66C). This is one of three occasions noted in the Commentariolum Petitionis as crucial for winning over the urbana multitudo and eorum studia qui contiones tenent. The other two were Cicero's promotion of Pompey and defence of Cornelius (Com. Pet. 51).

It is perhaps timely at this juncture to reiterate a point made earlier, also noted by Erich Gruen in his study of continuity of tradition in the late Republic: public expression of support or opposition had long taken the form of shouting and demonstrating at assemblies, public meetings and other gatherings like shows and funerals. Sometimes the participants would become violent, but this seldom happened and did not prevent the completion of normal judicial and other decision-making processes. ${ }^{535}$

Bearing this caveat in mind, we come to one of the most notorious popularis politicians of the period, Clodius. He was a master mobiliser of the plebs, with the help of his intermediate leaders, many recruited from the

535 Gruen (1974: 438f.) also notes that although at times volatile, the urban crowd was seldom irrational: their aims related to fixing food shortages and ensuring the senate did not usurp popular rights. He notes in addition that the pattern of taking out frustration against those more well off was repeated often throughout history, with reference to Hobsbawm (1965: 108-125) and Rudé (1981). 
neighbourhood vici, tribal headquarters and collegia. Others no doubt came to him voluntarily when his popularis leanings became clear. These supporters had many opportunities to demonstrate their loyalty. One of the first was following Clodius' misconduct at the Bona Dea festival in 62, which resulted in his facing the charges of sacrilege and incest in a specially constituted quaestio extraordinaria. 536 He sought to oppose the establishment of this special court. From this incident, we know he enjoyed the support of iuvenes, "Catilinarians", senators like Curio and his own bands of clients. The same people demonstrated their support by gathering in huge numbers and so intimidating the jury that the iudices demanded the senate pass a decree granting them a bodyguard (Cic. Att. 1.16.5). Plutarch suggests that the plebs supported Clodius in part because of their dislike of his aristocratic opponents (Caes. 10). Clodius was acquitted. According to Cicero and Dio this was because he bribed the jury (Dio 37.46.1-2). Yet as we have seen, the jury feared for their safety enough to demand the appointment of a bodyguard, so this incident may be interpreted as another case of the people exerting their influence through a demonstration of strength. Vanderbroeck supposes Clodius organised the gathering of his supporters, suggesting he perhaps mobilised support via operae. ${ }^{537}$ Yet we need also to consider the possibility, mooted by Gruen in regard to another

\footnotetext{
536 For legislation establishing this special court, and the people's response, see above. 537 Vanderbroeck (1987: 236).
} 
defendant, 538 that they acted out of spontaneous support for their patron or, depending on their relationship, amicus, and genuine enthusiasm for Clodius encouraged them to act in a threatening fashion towards the iudices.

Defence of the popular interest motivated those of the audience who expressed their opinion at Milo's trial in 56. The exact nature of the court is, in fact, unclear. There are two options according to modern commentators: Gruen suggests he was tried before a quaestio de vi, while Alexander says it was a iudicium populi, based on Cicero (Q. Fr. 2.3).539 Whatever the type of court, the prosecution was attacking Milo's conduct as tribune in 57 when he organised bands of men to take on those of Clodius in an effort to prevent Clodius' election to the aedileship. As Dio puts it, Clodius charged Milo with providing himself with gladiators (39.18). Clodius used the opportunity of the trial to attack Pompey. He put a barrage of questions to the crowd after Pompey had delivered his speech as witness. Plutarch provides details of his technique, likening the plethos to a trained chorus: Clodius would shake his toga as if a prearranged signal to elicit a response from his supporters (Pomp. 48.7). Yet it is possible that such toga-shaking was a traditional popularis technique, dating back to at least the days of Gaius Gracchus (Plut. Ti. Gracch. 2.2), and not a cynical sign of manipulation

538 Gruen (1974: 438) suggests spontaneity on the part of C. Cornelius' supporters.

539 Gruen (1974: 298 n. 139); Alexander (1990: 129 n. 2). 
of the masses. Gaius' "innovative physical presence became the prototype for future politicians wishing to associate themselves with his style of antiestablishment politics." 540

Cicero characterised the audience at Milo's, or at least those who participated in the question and answer "session", as operae Clodianae (Q. Fr. 2.3.2). We ought, however, to take into account his bias against Clodius, and so interpret this designation with a grain of salt. There was a food shortage at the time, and the nature of the questions reveals the real issue for the people gathered was their empty stomachs, not partisan politicking.

The ex-tribune Vatinius found support for his case amongst Caesar's milites. He had been charged with violation of the lex Licinia Junia for irregular legislative activities during his tribunate of 59 (Cic. Vat. 33; he failed to observe the trinundium, Schol. Bob. 140 St.). Soldiers and Clodius disrupted his trial. Vatinius chose to return to Rome to face the charges, as he had already set out to serve as Caesar's legate in Gaul. It appears Caesar sent soldiers to support the man who had secured for him command in Gaul Cicero states that Clodius "put himself at the head of your soldiers as their leader" (Cic. Vat. 33). Gruen interprets this trial as symptomatic of the

540 Corbeill (2002: 188). 
utilisation of the courts as a weapon in the propaganda campaign against the triumvirate. ${ }^{541}$ It is unusual to see milites taking part in activities in the forum as soldiers were not permitted within the pomerium except to celebrate their general's triumph. Cicero may have been denigrating the men's status for rhetorical effect, portraying them as soldiers when they may have been nothing more than the clients of Vatinius and Clodius - this speech is after all out and out invective against a man who was a witness against Sestius, whom Cicero was defending.

The universus populus demonstrated their displeasure at Aulus Gabinius. As tribune in 67 he had enjoyed popularity when he acted as rogator of the bill that gave Pompey command against the pirates. But he lost favour in all quarters, and won for himself a date in court twice in $54 \mathrm{BC}$, for his intervention in the so-called "Egyptian Question." He faced a charge de maiestate for restoring Ptolemy Auletes in contravention of a senatorial decree. ${ }^{542}$ Cicero reports that not only were the senate offended, but also the people: on the day of the trial, Gabinius was nearly crushed by a huge, hostile gathering of the whole people (concursu magno et odio universi populi paene adflictus est, Q. Fr. 3.1.24). Similarly Dio (39.62.2) reports the reaction of "practically the whole demos" as they tried to tear him to pieces, after ${ }^{541}$ Gruen (1974: 292). On the incident see Cic. Vat. 33f.; Sest. 135; Schol. Bob. 140, 150 St. 542 Although he had been unwilling to act on the question of who should reinstate Ptolemy, he had been encouraged to do so by Pompey (Dio 39.55.3) and Antony (Plut. Ant. 3). 
being stirred up by Cicero. Gabinius desperately needed to cash in on his alliance with Pompey. Despite the best efforts of his opponents, especially Domitius and Appius Claudius (the latter hoped to please the plebs, Dio 39.60.3-4), he was acquitted after Pompey made his wishes clear: vehemens in iudicibus rogandis (Q. Fr. 3.3.3) - an illustration of the strength of Pompey's influence over the jury. But as the following episode reveals, he failed to convince the plebs that Gabinius was worth saving.

Gabinius was not so lucky at his second trial in 54. This case shows how popular pressure could bring criminal conviction: the threat of being expelled from the senate whether by censor or by jury as a result of criminal conviction was real. If members of the elite influenced the decisions of censor and juror, so too did citizens outside the ranks of the extremely wealthy. Gabinius underwent a second trial at the same time for extortion (de repetundis), alleged to have occurred when he accepted the mission to reinstate Ptolemy.543 His involvement in the restoration of Ptolemy had greatly upset the plebs (Dio 39.61.3-4), whose superstition convinced them that Gabinius had caused the Tiber to flood when he went against the Sybilline Oracle which forbade anyone to enter Egypt with an army (Dio 39.15.2).

543 See Fantham (1975) for the details. 
Dio (39.60-63) and Cicero (Q. Fr. 3.1.15) reduce the incident to a case of factional politics. He tells us that Gabinius' opponents were the consuls Domitius and Ap. Claudius, opposed to the faction of Pompey for what they could gain personally from the pressure they applied to Gabinius. They used the superstition of the demos and plethos to convince them that the Tiber had flooded because Gabinius had led an army to Egypt against the recommendation of the Sybilline Oracle. Yet if we put this factional politics aside, we see popular power at work. When the jury acquitted Gabinius of the first charge, the people threatened to execute the jury, but then focused on the remaining charges, of which Gabinius was found guilty and so exiled (Dio 39.63.5).

Cicero and Dio are our main sources on Gabinius' trials. Yet we have good reason to treat Cicero's evidence with care. He fell out with Gabinius as early as 58 when Gabinius benefitted from the exile of Cicero (Q. Fr. 3.1.15), and again in 56 we find Cicero carping about Gabinius in his capacity as governor of Syria where he struggled to deal with pirates and did not get on well with publicani (Cic. Sest. 71; Prov. Cons. 9-13). 
$52 \mathrm{BC}$ witnessed the final two trials to be considered here. The first was that of Milo; this time the charge was the murder of Clodius. ${ }^{544}$ The second was the trial of Scaurus, who had been in the thick of the troubles in 53. He was prosecuted for electoral corruption and violence. In both, private citizens clashed with the soldiers Pompey had stationed around the forum to keep the peace in a turbulent year that saw him appointed sole consul by senatorial decree. His appointment itself was the result of popular pressure that saw the growth of a rumour suggesting Pompey be created dictator (Asc. 35-36C).

Milo's trial pitted the quasi-official military forces of Pompey against the surviving friends of Clodius, termed populus, Clodiana multitudo and by implication included tabernarii as on the last day Plancus ordered shops closed to allow their participation (Asc. 52C). Although Pompey claimed he was only interested in fighting the Clodian protesters as part of his new role as sole consul and protector of the state, factional politics may also have played some part in his actions. So too concern for his own personal safety may have influenced his decisions. On the first day, the crowd response came from the Clodian side, when the Clodiana multitudo caused a tumult. When we analyse their motivation, we see that the Clodians sought to show their support for one of their own, C. Causinius Schola, as he underwent

${ }^{544}$ Gruen (1974: 338-343). 
cross-examination as a witness in the trial (Asc. 40C). Their ardour was calmed for the next two days of the trial, when Pompey appeared with a body guard (praesidium) in attendance (Asc. 40, 50-51C), in response to an appeal from Domitius to provide protection, and after the sole consul expressed at a contio his fears that Milo wanted him killed.

When the trial was adjourned on the last day, the tribune T. Munatius Plancus appealed to the populus at a contio to refuse to let Milo escape (Asc. 40, 52C). Pompey posted soldiers on the hills around the forum, as an unofficial police force to protect Milo's defence team - or at least that is how Cicero chose to explain their presence in the speech he later published of the defence he was unable to deliver through fear at the time (Cic. Mil. 3; Asc. 41C; Plut. Cic. 35). The soldiers found cause to act when some of the citizens assembled raised an outcry at the military presence, but the soldiers silenced these objectors with a slap of the sword, and when their protest persisted, some were slain (Dio 40.53.3). The same happened when the people tried to intervene on behalf of Scaurus during his trial for electoral corruption in 52 . They were stymied and some killed when Pompey again lent the support of his forces to peace keeping. (App. BC 2.24).

But what was the nature of the relationship between defendant and supporters? How did they ensure the support would arrive at the forum? 
How were supporters organised? Senators charged with maiestas, typically after holding the tribunate, used collegia and operae to defend themselves (as we saw in the cases of Cornelius and Manilius above). The ex-tribune Vatinius used milites and Clodius to disrupt his trial for his activities during his tribunate of 58 (Cic. Vat. 33f.; Sest. 135). Pompey used his soldiers to keep the peace during trials on several occasions, and on the two instances examined above sent his soldiers against the people when they demonstrated support, in the first example for the prosecution, and in the second for the defence. As Rome had no police force, this is not as illegal as it sounds. Pompey had been charged with the duty of restoring order when he was appointed sole consul in $52 \mathrm{BC}$. He was merely doing his job, albeit along partisan lines.

Criminal trials in the late Republic reveal levels of popular participation beyond the short-lived jury service of tribuni aerarii. Ex-magistrates relied on the support of their clients to extricate themselves from trials based on trumped up charges. Popular demonstrations ranged from shouting to more violent expressions of support, especially once Pompey's soldiers became involved. Popular motivation was based not only on loyalty to senatorial patrons on trial, but also took into account issues behind the case, including the citizens' right to elect candidates and not have them removed from office, the right to enact laws without having the senate annul them, 
and what became a de facto right after years of reforms: access to subsidised food.

CASE STUDY: LUDI ET GLADIATORES

As we saw in the introduction to this chapter, Cicero purported that ludi offered a better gauge of a man's popularity than comitia and contiones (Sest. 115). He also suggested that shows (ludi et gladiatores) were a good place to assess one's popularity apud sordem urbis et faecem - a new experience for him now the misera ac ieiuna plebecula had begun to greet him with ovations after recognising that he was a favourite of Pompey (Att. 1.16.11). It is difficult to confirm the status of these participants, as Cicero exaggerated the lowly rank of those who applauded his presence because Pompey had disappointed him and these were Pompey's clients. The extremely poor he describes should not have been able to afford the ticket price to gain entrance to $l u d i$, but as we see below, popular patrons distributed tickets via collegia and vici, thus opening up participation at ludi to those who might otherwise have been excluded.

The evidence for participation at ludi is scant but nonetheless enlightening, revealing as it does a snapshot of Roman social life, which in turn illustrates 
interaction between orders. Plutarch records an incident that occurred in 63 in the temple of Bellona where spectators had gathered to watch a show. This was the first performance at which a law passed by the tribune Roscius in 67 was applied, segregating equites from the rest of the audience in the theatre. According to Plutarch (Cic. 13.2-4), the other spectators (polloi) objected to the equestrians receiving special seats and hissed at him, at which point the equites (politai) applauded him. Vanderbroeck interpreted this incident as an anti-popularis demonstration, claiming Roscius was popularis when he proposed the law to benefit equestrians because currying the favour of the equestrians was a typical popularis ploy in their battle against the optimates. ${ }^{545}$ There is another way to read this though. Plutarch says it is the polloi who are outraged; that is, the majority. They are angry at Roscius not for any ideological reason, but because favour was shown to an order not their own. The second explanation seems more likely: in the following example we also that access to ludi was jealously guarded by many citizens, from all orders.

The equites were busy again in 59. At the ludi Apollinares members of the equestrian order cheered Curio for his opposition to the triumvirate, while Pompey was pilloried by the actor Diphilus for his unsporting amicitia, and

545 Vanderbroeck (1987: 230). 
Caesar was greeted with a hostile silence (Att. 2.19.3). Cicero interpreted their action as a reflection of the populi sensus (ib.). This was shortly after the boni had applauded Curio in the forum, but hissed and shouted at the praetor Fufius, a well-known adherent of Caesar (Cic. Att. 2.18.1). The absence of any reference to the plebs suggests they were not present, or at least did not join boni and equites in this demonstration against the extralegal triumvirate.

An actor had a leading role in $57 \mathrm{BC}$ too, when at his bidding the populus Romanus indicated their support for the senaorial decree in favour of Cicero's recall. The people had gathered to watch a show when the news was announced in the theater, and as they entered, individual senators were applauded, especially the consul Lentulus Spinther. When Clodius entered, however, the crowd turned against him, hissing and threatening him. When the actor mentioned Cicero, the audience cheered him (Cic. Sest. 116-123). Jeff Tatum has argued against Vanderbroeck who suggests that audiences usually displayed an anti-popularis attitude. ${ }^{546}$ Tatum shows that Cicero, our main source, was using the term popularis ironically when he used it of Clodius. Rather, Cicero believed Clodius was no true popularis. Therefore, Tatum rightly concludes, the spectators usually applauded "true" popularis politicians.

546 Tatum (1990); Vanderbroeck (1987: 77 ff.). 
Shortly after this event, another pair of opponents pitted themselves against one another, this time before a more diverse audience than the above examples: omne genus hominum (Cic. Sest. 124-126). According to Cicero, at gladiatorial games hosted by Q. Caecilius Metellus Nepos in the forum, the universus populus Romanus applauded the arrival of P. Sestius, but when Clodius' brother Ap. Claudius showed himself he was hissed. In his capacity as Sestius' defence counsel, Cicero's words must be taken in context. The evidence for this case is from the speech Cicero wrote in defense of Sestius. He sought to paint a glowing picture of the defendant and so was recalling past postive incidents, and putting an extra gloss on them by denigrating opponents, namely Ap. Claudius, additionally tainted for being the brother of Cicero's foe, Clodius. Moreover, Sestius had been active during his tribunate on behalf of Cicero in securing his recall from exile, so Cicero poured on the praise to repay his benefactor.

Upon his return to Italy, Cicero was similarly excessive in his description when he reported that Clodius and his supporters forced their way into the theatre at the Megalesian games, painting the incident as an attack on the equites and boni: "vis enim innumerabilis incitata ex omnibus vicis conlecta servorum ab hoc aedile religioso repente $<\mathrm{e}>$ fornicibus ostiisque omnibus in scaenam signo dato inmissa inrupit" (Cic. Har. Resp. 22). It is not clear 
what motivated the Clodians, other than that they did not have tickets to the show. It has been suggested that Clodius may not have had time to distribute tickets to the urban plebs, 547 but such a theory seems unlikely when we consider what we know about Clodius' networks. He had lieutenants in the collegia and vici to ensure efficient dispersal of tickets. In terms of participants, as Vanderbroeck notes, Cicero often alleged Clodius' supporters were slaves. Some slaves no doubt numbered amongst his supporters, but so too did members of many other groups. Cicero himself mentions that the slaves were gathered from all the neigbourhoods (vici), so it could be expected that they would have rallied other adherents, free and freed, on the way, either by meeting them on the streets or as word spread.548 In this way, we get a more accurate picture of this episode: Clodius and his supporters, both slaves and freed members of the plebs urbana forced their way into the games because their access had been denied. They merely sought to participate in Roman public life, not topple the state as Cicero would have us believe.

A final example of popular participation in the theater: the people applauded Milo in 54 BC (Cic. Q. Fr. 3.1.13). We know no other details of

547 Vanderbroeck (1987: 253).

548 Vanderbroeck (1987: 253f.) suggests the Clodians included shopkeepers along with slaves in their number, but others were clearly involved too. 
the event, other than Caesar's opinion of the applause. The emphasis is on the existance of the applause not the participants.

Ludi et gladiatores were an integral part of Roman public life. Those excluded sought entrance by any means so that they too could participate. In addition ludi were, as Cicero claims, an important venue for the testing of public opinion, expressed verbally and, sometimes, violently. We must not follow in his footsteps and negate the validity of some demonstrations by demeaning the status of the participants to that of the most humble. All orders of society were involved in demonstrations in the theatre at different times, ranging from showing their support for popular champions, to expressing their frustration at favouritism shown by magistrates to orders other than their own.

\section{CASE STUDY: TRIUMPHS}

Triumphs offered the senate the opportunity to show their gratitude to a conquering magistrate by voting to grant him the right to hold a triumph (Liv. 3.63; Polyb. 6.15). At the same time, the populus Romanus was given the 
chance to display loyalty to their victorious leader. ${ }^{549}$ For this reason, triumphs were jealously guarded by the political elite as a means of accruing dignitas and auctoritas, so much so that during the reign of Augustus the triumph became the prerogative of the imperial family. Three triumphs will illustrate the nature of the collective behaviour typically shown at these events: the triumph of Pompey in 61 celebrating his victory over the pirates and Mithridates, the unofficial triumph of Cato the younger upon his return from Cyprus in 56, and the triumph of Pomptinus for his victory over the Gauls in 54. While the first two examples were celebrations of Rome's success and no disturbances are recorded, the last experienced some violent opposition as the supporters of the imperator fought with those opposing the granting of a triumph.

In the first case, the victorious general Pompey put on such a great show for the plebs that the procession and ritual lasted two days. (Flor. 2.13.9; Plut. Pomp. 45; Vell. Pat. 2.40.3-5). The plebs responded by naming him Magnus in a contio: "Pompeius de liberis Mithridatis et Tigrane, Tigranis filio, triumphauit Magnusque a tota contione consalutatus est" (Livy 103). A short notice, this summary nonetheless shows that a general could confirm for himself his standing in the hearts of the people (here undefined) by staging his own show in the form of a triumph, where he could receive

549 On the people's interpretation of the triumph, see Beard (2007: Ch. 2). 
feedback, as it were. The triumph also allowed him to communicate his achievements to his fellow citizens. ${ }^{550}$

This next case features Cato the Younger who stage-managed his own return from Cyprus to resemble a triumph. So successful was his display, and so impressive the amount of his booty, that the demos crowded the banks of the Tiber and the senate honoured him with an extraordinary praetorship, which he declined. Both our sources comment on the lack of respect he showed his fans by not disembarking until he reached his destination (Plut. Cat. Min. 39; Vell. Pat. 2.45.5). Senate and people alike approved of a good show to celebrate the state's successful acquisition of new lands and new riches.

When Pomptinus wanted to celebrate a triumph for his victory over the Allobroges in 62-61, the senate did not initially grant him permission. He did not gain senatorial permission until 54BC. Dio relates that Pomptinus' friends tried to gather more supporters: the praetor Servius Sulpicius Galba illegally and secretly granted citizenship to some men before dawn on the day of the assembly to vote on the triumph, so that they could participate in

\footnotetext{
550 See Gregory (1994: 84) on the importance of the triumph as a means of visual communication in a largely illiterate society, building on Nicolet's (1976: 355) suggestion that triumphs focused on public display dating from the second Punic war, when generals instead of gods began to take credit for saving citizens from slavery.
} 
the vote (Dio 39.65). ${ }^{551}$ Tribunes who had been excluded from the assembly took exception and fought in the triumph causing bloodshed. Dio is the only source of evidence for popular involvement in this case, 552 and has misunderstood his source regarding the motivation for the tribunes' run in with, presumably, supporters of Pomptinus. Dio says they were angry at being excluded from the assembly, although there was no exclusive assembly to vote on the triumph. He may have mistaken the meeting at which Sulpicius Galba granted citizenship for that at which the people voted for the triumph. Despite the confusion, Pomptinus' triumph provides evidence that tempers could run hot at such events, where men and their supporters competed for pre-eminence over opponents.

Triumphs were hard won but worth the effort for the amount of kudos accrued, as we see especially in the case of Pompey. Cato's shows the positive effect of even a mock triumph on a man's dignitas. In both of these cases, the imperator is nothing without the adulation of the masses. Yet again we see the importance of popular participation in confirming the auctoritas of an individual. Pomptinus' case illustrates the difficulty of achieving a triumph in the competitive environment of the late Republic.

\footnotetext{
551 On the procedure for securing a triumph, see Beard (2007: 200-205).

552 Cicero (Att. 4.18.4) mentions that Pomptinus' desire to celebrate a triumph is opposed by Cato, Servilius and Q. Mucius because no law was ever carried granting him imperium, but gives no details of the popular involvement. He also tells his brother of his own intention to support Pomptinus (Q. Fr. 3.4.6).
} 
CASE STUDY: POPULAR DEMONSTRATIONS TO HONOUR CHAMPIONS

Staying with the theme from the previous section, we here examine popular responses in honour of those who have championed the popular cause or otherwise found themselves in good favour with the people. Romans demonstrated support or opposition in a number of ways.

This group of popular demonstrations illustrates intermediate leadership, and so provides additional evidence for organisers outside the elite. That urban and rural plebs sought to honour these popular champions also emphasises the existence of popular causes that needed addressing.

It is well known that Caesar enjoyed a considerable popular following. But the effort he put into this cannot be underestimated. He was one of the most successful organisers and propagandists when it came to rallying the plebs to demonstrate their support. Below we see him use the funeral of his aunt daughter to do so. And here he uses his Marian connections to cement his popularity. In $65 \mathrm{BC}$, during his aedileship, he secretly ordered the restoration of statues to commemorate Marius' victories over Jugurtha, the 
Cimbri, and the Teutoni, and these he had set up during the night, in the teeth of the opposition of the optimates (Vell. Pat. 2.43.4; Suet. Jul. 11). He had mixed results. Some claimed that by violating laws he was aiming to set himself up to usurp sole power, but that his organisation was superior to these rumours and mobilised "the partisans of Marius who arrived suddenly and filled the Capitol with their applause" (Plut. Caes. 6.3). ${ }^{553}$ In 63 the plethos demanded the senate release Caesar from the curia after an unusually long meeting at which he was to clear himself of charges of involvement in the Catilinarian conspiracy (Plut. Caes. 8.3f.). Again, in 62, the multitudo demanded Caesar's restoration to the praetorship after the senate removed him from office for backing the laws of Caecilius Metellus. The senate praised Caesar for withdrawing to his house in order to pacify the people and so prevent violent clashes (Suet. Jul. 16). ${ }^{554}$ The plebs were quick to show their support by coming to the aid of Caesar.

Pompey vied with Caesar for popular support. When Pompey returned from the East in 62 the people of Italy escorted him to Rome, so relieved were they to see him disband his army (Plut. Pomp. 43.3). So little is known about this case that we do not know who mobilised the people. The demonstration may have been spontaneous as news spread that the people's

\footnotetext{
553 Gruen (1974: 76).

${ }^{554}$ Gelzer (1968: 51f.).
} 
hero was returning peacefully. The incident foreshadows the glorious return of Cicero in 57, and makes one wonder whether Cicero modelled his on Pompey's.

In 50 BC Pompey became ill while at Naples, perhaps with malaria. 555 Festivals followed his recovery as all the cities of Italy had been so worried about Pompey's health that they had vowed public sacrifices for his safety (Dio 41.6.3f.; Vell. Pat. 2.48.2). In June, Cicero wrote to Atticus concerned about Pompey's bad health and the potential for the balance of power to tip should he not recover (Att. 6.3.4); but his attitude had become hysterical by March 49 when he claimed the popular demonstrations were a sham (Att. 8.16.1; 9.5.4). Cicero was clearly venting his frustration at Pompey's popularis stance by implying Pompeians orchestrated the vows of the Italian cities. According to Plutarch, this display of popularity started with a certain Praxagoras, and was then imitated by towns in the neighbourhood until the thanksgiving spread throughout all Italy to become one of the main causes of his war against Caesar as Pompey became over-confident (Plut. Pomp. 57). We have no further information on Praxagoras, so must make an educated guess as to his relationship with Pompey: he was likely a client. In

555 Seager (2002:145). Juvenal (10.283-285) says that the public vows of many cities overcame the fevers Pompey received from Campania. Pompey was not, however, so sick that he could not write a letter to the senate emphasising his own fairness and stirring up prejudice against Caesar (App. BC 2.28). 
this case then, we see clients organising demonstrations to honour their patrons.

Cicero had his share of popular adulation too, thanks to the hard work of amici such as Atticus (Cic. Att. 4.1.1) and Sestius, while Cicero was suffering in exile. Sestius was tribune at the time, and used his position to mobilise support for Cicero's recall. Cicero's gratitude to him is a feature of his speech made in Sestius' defence. When the decision was finally made, the populus Romanus applauded the announcement of the senate's decision to recall Cicero (Sest. 116-123). ${ }^{556}$ The legislation was passed with the support of citizens from the towns and municipalities of the peninsula (Cic. Dom. 75), with "incredibili concursu Italiae" (Cic. Att. 4.1.4). Intermediate leadership was also involved. In anticipation of Cicero's return from exile, his nomenclator organised individuals to greet him; the infima plebes filled the steps of the temples at the Porta Capena and congratulated him with magnificent applause (Cic. Att. 4.1.5). The populus Romanus honoured Cicero by escorting him, in immense numbers rejoicing (Cic. Dom. 76) A whole day was spent welcoming him home (App. BC 2.16). Cicero was desperate to convince men from all orders that he had recovered his dignitas and auctoritas so badly damaged by Clodius' legislation. Therefore we need

556 Tatum (1999: 181 f.); Vanderbroeck (1987: 246). 
to beware of exaggeration in his accounts of the degree of support and adulation he received, despite Plutarch's claim that "so great was the joy of the cities and the eagerness of men to meet him that what was said by Cicero afterwards fell short of the truth" (Cic. 33.8). Cicero's desperate need to have people believe his exile had not effected his political standing is highlighted by his comment to Atticus: "I have resumed what I thought there would be the utmost difficulty in recovering - my brilliant standing at the bar, my auctoritas in the senate, and a popularity with the boni even greater than I desired" (Cic. Att. 4.1.3).

Cicero was deliberately obscuring the fact that he was not without opposition, transferring Clodius' hostility towards his person to his house (Cic. Att. 4.1.3). The rural plebs, present in Rome to celebrate the ludi Romani, cheered him all the way home. But food supplies, already under pressure, could not cope with the influx of visitors. Clodius took the opportunity of the food shortage caused by the massive influx to stir up the plebs, blaming the scarcity on Cicero (Cic. Att. 4.1.6). ${ }^{557}$

Clodius also enjoyed popular demonstrations in his favour, as we have seen above. Another example serves to illustrate why he enjoyed such support

557 See Chapter Four on food shortages. 
amongst residents of Rome. When in 57 armati homines drove builders from the site of Cicero's house (Cic. Att. 4.3.2), Clodius was doing more than drive a thorn into Cicero's side. He had destroyed the house of Cicero, the man who had compromised the liberty of Roman citizens by executing Catilinarians without a trial, and built a shrine to Libertas on the site. Cicero destroyed liberty, Clodius, defender of the interests of the plebs, restored it. 558

The degree of ardent support explains his importance to Pompey as a man favoured by the plebs for his promotion of their interests. He addressed the people on behalf of Pompey in 56 when, following the conference at Luca, Pompey and Crassus had made a deal to stand together for the consulship of 55 but were experiencing senatorial obstruction to their request to postpone elections until their return. The plebs (plethos, homilos, polloi according to Dio 39.27.3-29.3) or the universus populus (Val. Max. 6.2.6) leapt to Clodius' defence when his entrance to the curia was barred by a group of equestrians sent by hostile senators to kill him. The people knew where their interests lay.

558 Allen Jr. (1984). 


\section{CASE STUDY: FUNERALS}

Funerals offered the people of Rome another chance to participate informally in political life by demonstrating their support of individuals and their factions. Like triumphs, they were surrounded by fierce competition for popular favour, as politicians fought to outdo each other. A successful funeral was like winning a triumph: an excellent opportunity to celebrate (and therefore increase) auctoritas and dignitas, and flaunt popularity and connections. Here we investigate the funerals of Sulla, Lucullus, Julia, and Clodius.

Sulla's funeral procession in 78 was disrupted when one of the consuls, Lepidus, tried to prevent it, but Catulus and Pompey joined with Sullan soldiers and veterans who had come in from the countryside to ensure Sulla was properly honoured (Plut. Pomp. 15.3). An unprecedented crowd from the plebs (plethos) flocked together (App. BC 105). Senate, equestrians, and all the legions that had served under Sulla rushed to join in the procession. Loud cries of farewell were raised by senate, equestrians, soldiers and finally by the plebeians. Some lamented his death because they longed for Sulla, but others were afraid of his army and the spirit of Sulla (App. BC 105f.). Members of every order thus demonstrated their respect for the 
deceased senator, even if some worried that the excesses of his regime were not yet over.

The demos reacted spontaneously to the body of L. Licinius Lucullus being carried into the Forum, when he died in $57 \mathrm{BC}$. The plebs requested he be buried in the Campus Martius, but his brother Marcus managed to persuade them to allow the family to lay him to rest in their estate in Tusculum (Plut. Luc. 43.2-3). The city plebs wanted to show him this one final honour as a mark of respect for his deeds as a general and statesman (Plut. ib.).

When Pompey's wife Julia died in 54, the people (populus, Livy 106; demos or plethos in Plutarch Caes. 23.7; Pomp. 53.4f) seized her body and honoured her memory by burying her in the Campus Martius. Unnamed friends (philoi) of Pompey and Caesar motivated the action (Dio 39.64). Who were these friends? Vanderbroeck suggests they were intermediate leaders, 559 but offers nothing more than that. It is likely they were connected to the collegia or vici, due to the amount of people they were able to mobilise.

The populus made the ultimate demonstration of their admiration when they made the curia Clodius' funeral pyre in 52 BC (Asc. 32-33C). The participants at Clodius' "funeral" included a diverse range of Romans:

${ }^{559}$ Vanderbroeck (1987: 259). 
infimaeque plebis et servorum maxima multitudo surrounded his corpse when it lay in the atrium of his house, then next morning an even bigger crowd eiusdem generis gathered, this time including complures noti homines plus the tribuni plebis T. Munatius Plancus and Q. Pompeius Rufus (Asc. 32C). At this point Asconius ceases to use neutral terminology and calls the those who bear Clodius' body to the forum vulgus imperitum (33C). He may be under the influence of Cicero here.

\section{CASE STUDY: ELECTIONS}

We will examine five instances of informal popular participation at elections held between 63 and 53 BC. Out of all our case studies, these were most violent due to the passion of the rival supporters, a reflection of the increasingly competitive nature of Roman politics. Candidates fought more keenly for more lucrative magistracies, and this competition was transferred to the electoral assemblies. The thermostat went up as the value of the prize increased.

People flooded into Rome to vote for Cato in 63 when he stood for the tribunate. He had at last decided to stand for the tribunate after years of declining the office. His motivation: he had heard that the Pompeian 
Metellus planned to put himself forward as a candidate. Cato wanted to have the chance to veto any Pompeian measures that Metellus might put forward (Plut. Cat. Min. 20). Plutarch records that, once his purpose became known, so many polloi came crowding in to encourage him that he was almost crushed (Cat. Min. 21). Plutarch's explanation of their support, however, is doubtless confused: these plebs were supporting a member of the optimates because he promised to increase the number of grain recipients (Plut. Caes. 8.6), not because they wanted him to check the moves of Metellus.

On the eve of the consular elections in 56 rival supporters (Crassus' soldiers and Domitius' slaves) clashed on the Campus Martius. According to Dio (39.31) Lucius Domitius withdrew his candidature after a slave accompanying him to the elections was killed - Crassus had brought stratiotai to Rome to make sure there was no opposition to the election of Crassus and Pompey. Appian relates the same details: when the candidates were making their way to the assembly they came to blows, and finally somebody attacked Domitius' torchbearer with a sword (BC 2.17). Plutarch's version is more dramatic, painting Cato as the hero of the hour: Cato, Domitius' brother-in-law, stopped Domitius from fleeing with the others when they were attacked, but "exhorted him to stand his ground, and not to abandon, while they had breath, the struggle in behalf of liberty 
which they were waging against the tyrants" (Cat. Min. 41.5). Cato refers here to the liberty of members of the senatorial order to compete as equals for curule office. This of course in the context of the conference at Luca. Soldiers beat the slaves into submission, then Pompey and Crassus had their opponents shut up in their homes, and so they were elected (Plut. Crass. 15.4-5). Domitius did not, in the end, stand for election. This case illustrates the superiority of brute military strength over a fighting force of slaves, and explains why soldiers were barred from the city. The soldiers stood to gain by supporting their commander, both by getting their man elected (and so the promise of future benefits such as land on demobilisation), and by donatives received from the general. The plebs participated in a public meeting; for when the deal made between the triumvirs became known, and the optimates were angry, Marcellinus questioned Pompey and Crassus regarding their intentions to stand for the consulship. The majority of the people demanded they answer, to which Pompey equivocated that perhaps he would stand, and perhaps he would not. Crassus on the other hand provided a craftier answer: he would take which ever course he thought would advantage the commonwealth (Plut. Pomp. 51.4f.). And so the war to win over the people continued. 
At the praetorian elections in 55 the triumvirs used force and obnuntiatio to get Vatinius elected. ${ }^{560}$ When the first tribe voted for Cato, he announced he had heard thunder, and so dissolved the assembly by this technique of obnuntiatio (Plut. Cat. Min. 42.3). Pompey then resorted to extensive bribery, ejected the beltistoi (optimates) from the Campus Martius and secured the election of Vatinius (ib. 42.4). Those who had been bribed slunk home guiltily for casting illegal votes, while the rest of the people (plethos) gathered together to express their indignation. Cato addressed these citizens in a contio summoned by a tribune, at which he cast Pompey and Caesar in a bad light. At the end of the day, he was escorted home by a crowd bigger than that which accompanied the elected praetors (ib 42.5). Doubtless these Romans had not forgotten Cato's own bribe in 62, when he offered the poor grain at heavily subsidised prices.

Dissatisfaction at exclusion from participation, given added impetus from candidates' rivalry, finally came to a head in 53 BC. Defeat was admitted and elections cancelled after Clodius and Milo caused a ruckus at the consular elections. Clodius had used the same tactic when excluded from the Megalesian games in 57 (Cic. Har. Resp. 22). Then, they forced entrance

\footnotetext{
560 Dio (39.32.1-2) records violence only at the aedilician elections. . This was a more violent affair than the praetorian elections: Pompey's toga was spattered in blood because so many people near him had been slain (Plut. Pomp. 53.3). The record is too slight, however, to provided us even with the name of an organiser, or the status of participants. Vanderbroeck (1987: 257) suggests Pompey was responsible, I assume on the basis of his role in arranging for Vatinius' successful candidature.
} 
to the games; now he used his supporters to force entrance to the saepta and ordered his men to draw swords and hurl stones during the consular elections in 53 BC (Cic. Mil 41). Clodius was backing Hypseus and Scipio as candidates against Milo. Asconius (30C) relates how the factiones of Clodius and Milo clashed: they fought often in Rome, and although both were equally ruthless (audacia), Milo stood for the meliores partes - elections were impossible to complete because of the reckless hostility of the candidates. It must be reiterated: both factions armed their supporters. Clodius used his to gain entrance to events from which he was excluded; Milo to bar the entrance of the Clodians.

Popular participation in elections took the bloody form of fighting to support favourite candidates. The stronger the force of supporters, the more likely a candidate was to cow opposition, to the extent even of deterring them from standing for office. Popular motivation rested on both public interest, such as support of Cato for his promised grain reform, and factional politics, especially in the case of clashes between the supporters of Clodius and Milo where we see Milo's side using obstructionist tactics to prevent his opponent from gaining the upper hand.

SENATORIAL RESPONSES 
The senatorial response to popular pressure provides evidence of the strength of popular power: the Roman government's response to popular demonstrations reveals that citizens were able to wring concessions and reform out of the conservative core of the senate by expressing their opinion in the forum, Campus Martius and other public meeting areas on some occasions - witness the land, food and debt reform in the people's favour but on others the senate responded to block popular efforts to secure their aims.

Hostile responses to popular discontent included constitutional change (e.g. Sulla seriously decreased the powers of the tribunes), legislation de vi, policing, and senatorial decrees, especially the senatus consultum ultimum (SCU). ${ }^{561}$ The SCU was an emergency declaration, giving consuls the power to protect the state by whatever means necessary, though the details were specific and varied. This decree was first used against Gaius Gracchus, although it was not given this name.562 It was also modified for use in civil wars against Sulla in 83 , Lepidus in 77 , and the Catilinarians in 63 , so that the decree allowed magistrates to take military precautions. Magistrates

\footnotetext{
${ }^{561}$ Nippel (1984; 1995); Vanderbroeck (1987: 153 ff.).

562 "SCU" is a modern term, and derives from Caes. BC. 1.5.3 (OCD s.v. "SCU" (A. Momigliano and A. Lintott)).
} 
and tribunes whose vetoes went against the dominant state faction also found themselves the object of the SCU in $100,62,53,52,49,48$ and 43.563 In short, the SCU not only permitted the senate to levy troops, but it also directly identified public enemies. ${ }^{564}$

While higher magistrates and censors could intervene in certain matters, there was in fact little if any state intervention. In addition, the army was excluded from crossing the pomerium and entering the urbs Romana. When they did intervene, magistrates used coercitio and censorial punishment to make examples of the elite. Riotous public meetings were not usually a cause for concern, though authorities would react if disturbances were serious enough. The senate and curule magistrates issued special mandates to aediles and tresviri capitales (best described as police magistrates) to deal with searches and arrests. The tresviri originally supervised the jail and executions therein, and later organised the vigiles. They could arrest and punish runaway slaves. ${ }^{565}$

563 See Nippel (1995: 63ff.) and Lintott (1999a: Chapter 11).

564 Public interest was the best excuse to destroy personal/political enemies, and so a new charge was created, that of being a hostis, which meant death with impunity (Nippel 1995: 66). The people could and did protest against some hostis decisions by, e.g. refusing to plunder (Val. Max. 4.3.14).

565 Nippel (1995: ch. 1). 
When senators disagreed with a tribune's bill, they could hinder the legislation in three ways: intercessio, obnuntiatio, and filibuster. Cicero provides us with an example of all three techniques (Att. 4.3). Piso shows how to respond when a veto is ignored: he forbade the herald to continue reading Cornelius' bill in 67 in violation of Globulus' veto (see above). Bibulus illustrates the use of obnuntiatio, the reporting of omens that cancelled assemblies, when in 59 he obstructed Caesar's legislation. A third regular senatorial technique was filibuster, as when Metellus talked out the time to prevent the senate from making a decision.

In 57 , the tribune Sestius was attacked and seriously wounded by some of Clodius' men when he tried to prevent a tribal assembly by obnuntiating, despite the fact that obnuntiatio had been outlawed in January of that year. Sestius went to the consuls at the temple of Castor to announce that the omens were unfavourable (Cic. Sest. 79f.; Mil. 38; Red. Sen. 7; Red. Pop. 14). He paid the price for acting in such a partisan and illegal manner. This case illustrates precisely the tension between senatorial and popular powers that was a theme of the period. Sestius considered himself immune to the law banning obnuntio, even though it had been passed by the populus Romanus in the tribal assembly and was therefore binding on all Romans. 


\section{CONCLUSION: WHAT KIND OF DEMOCRACY?}

Those members of the populus Romanus present in the Forum during a contio had the opportunity to take part in the decision-making process. They could cheer and applaud in support, and shout out their opinion on the matter being debated, or make it known through more physical forms of expression. Magistrates hesitated to take their bills to the voting assembly without first ensuring that they had popular backing for fear of losing face should the bills' passage fail. The same influence extended to the legislative assemblies themselves. In this way we can see the power the people had over the elite.

Just as they needed the populus to enact laws, the members of the aristocracy also needed popular support to protect themselves from criminal charges. Acquittal was more easily won with the backing of a passionate group of citizens. 566

Other events gave senators the chance to evaluate levels of support, and gave the people the opportunity to express their feelings. Access to ludi et gladiatores was considered a right, as these were not only entertainment

\footnotetext{
566 Other factors also contributed to the likelihood of success, such as the strength of evidence against the accused, the skill of his defense team, and the ability of the jurors to make their decision with objectivity.
} 
spectacles, but also an integral part of Roman public life at which politicians tested public opinion and flaunted their own popularity, if they had it. Similarly triumphs relied on popular participation to confirm the auctoritas of the victorious individual. In a like manner, the involvement of the populus Romanus at funerals bolstered the auctoritas and dignitas of the deceased and their family.

Roman citizens were able to take part in elections formally by voting. They could also find themselves involved informally, fighting in support of favourite candidates or in defence of the public interest. Popular political participation was not always conducted in an organised and seemly fashion, especially when enthusiastic protection of popular champions boiled over as a result of frustration at an insensitive, selfish and obdurate conservative clique in the senate. 


\section{CONCLUSION: WHAT KIND OF DEMOCRACY?}

The populus Romanus had an important role to play in the decision-making process at Rome in the late Republic. Their political power had both a formal and an informal dimension. From the earliest days of the Republic the citizens had gathered in centuries to perform their official duty and elect the magistrates who would direct the state with the support of the electors. And since the lex Hortensia of 287 citizens had assembled in their tribes to enact laws binding on the whole population. Informally, the people compelled magistrates and senate to compromise and propose bills in the popular interest. Popular opinion and pressure had a great deal of influence at the decision-making level of Roman government.

The balance of power had gradually shifted so that by the late Republic the members of the top census groups no longer dominated the assemblies. Rural tribules had been moving to Rome, bringing their rural registrations with them, which changed the balance in the tribal assemblies so that the ballot of the non-elite voter now counted. When he cast his vote, although he was only contributing to the vote of his unit, it was now as a member of a group made up of a more diverse selection of citizens. 
In addition to the legally prescribed avenues of participation, the people also had recourse to informal means of involvement in politics. Timehonoured methods throughout the Republic were secession, mutiny, and the refusal to enlist. The risk these demonstrations of popular frustration posed to the security of the state compelled the senate to heed the protestors' demands for debt relief, land reform and improved conditions of service.

The people saw to it that the issue of insecurity of food supply was dealt with. Rome had lacked the infrastructure to maintain a reliable food distribution, but popular pressure forced concessions out of the senate that resulted in marked improvements both to the security of supply and the provision of food subsidies for citizens. In the process, politicians such as Pompey enhanced their dignitas beyond normal expectations. Such prestige was treasured by the elite - without it they were nothing in the competitive world of Roman politics. The prestige that the people's support brought was a powerful motivating force in Roman politics, persuading, for example, popularis politicians to restore tribunician power.

Contiones provided Romans with the opportunity to take part directly in politics through attendance at informal debates on legislative proposals in the Forum. Rogatores were not keen to put their dignitas in danger and take 
a bill to the vote until they were sure their proposal would be successful. Public opinion was tested when magistrates put questions to the people and listened for their response. Otherwise, the speaker could use the volume of applause as a measure of approval. The people had power over the elite because they had to be persuaded and cajoled to show their agreement and support magistrates' proposals.

Senators did not only need popular backing to enact laws, but also to protect themselves from guilty verdicts in court. Bribery of the jury was one way to secure acquittal; better still was to utilise the support of the people to compel one's opponents to withdraw charges, as seen in the case of Cornelius and the brothers Cominii.

Politicians had numerous chances to evaluate levels of support, and the people a corresponding amount of opportunities to express their pleasure or disapproval at the politicians' performance and policy choices. Senators tested public opinion and flaunted their own popularity at the performances of ludi et gladiatores. Similarly triumphs needed the people's involvement, otherwise there would be no audience to confirm the auctoritas of the triumphator. Funerals likewise relied on the involvement of populus Romanus to celebrate the auctoritas and dignitas of the deceased and their family. 
Roman citizens were not only able to take part in elections formally by voting, but also informally, fighting to defend favourite candidates or champions of popular causes. Popular political participation did not always occur in a composed fashion, especially when enthusiastic protection of defenders of the people's interest resulted in physical violence through frustration at an insensitive, selfish and obdurate conservative clique in the senate.

Democratic elements did exist in the late Roman Republic. The demos or populus Romanus made demands and these were met, eventually, with more success than in earlier periods. These achievements were due to the popular power that exerted itself in the form of resistance to senatorial commands and demonstrations of support for those who would pass measures that improved the conditions for the needy.

The research in this thesis supports the finding that popular political participation in the late Roman Republic resembled that of an emerging democracy. Citizens outside the senatorial and equestrian orders took on an increasing role in the decision-making process, although their role was on occasion extra-legal and untraditional. But the Romans had always taken pride in developing innovative new practices. The last days of the Republic 
were a preview of what was to come: the reining in of popular power as the people found themselves with increasingly few men willing to represent their cause. Caesar began what his successors in the principate would complete, usurpation of power by one man, the princeps. 


\section{BIBLIOGRAPHY}

Periodicals are abbreviated as in L'Année Philologique. All dates are those of original publication unless otherwise indicated. Book reviews are not included unless cited in footnotes.

\section{Primary sources:}

a) Editions

Ampelius, Liber Memorialis, ed. E. Wölfflin, Leipzig, 1854.

Appian, Appian's Roman History, trans. H. White, 4 vols., Cambridge, MA, 1912-13.

Aristotle, Politics, ed. H. Rackham, Cambridge, MA, 1967.

Asconius, Orationum Ciceronis quinque enarratio, ed. A. C. Clark, Oxford, 1907.

Asconius, Commentaries on Five Speeches of Cicero, ed. and trans. S. Squires, Bristol, 1990.

Cassius Dio, Roman History, ed. and trans. E. Cary, Cambridge, MA, 1914-27.

Cassius Dio, Cassii Dionis Cocceiani Historiarum romanarum quae supersunt, ed. U. P. Boissevain, Berlin, 1955. 
Caesar, C. Iuli Caesaris Commentariorum pars prior [et pars posterior], ed. R. L. A. Du Pontet, v. 1 De bello gallico; v. 2 De bello civili, Oxford 1900-1908.

Caesar, The Gallic War, trans. H. J. Edwards, Cambridge, MA, 1917.

Caesar, The Civil Wars, trans. A. G. Peskett, Cambridge, MA, 1914.

Cicero, M. Tulli Ciceronis orationes, ed. A. Clark, 6 vols., Oxford, 19051911.

Cicero, The Speeches: Pro Archia poeta, Post reditum in senatu, post reditum ad quirites; De domo sua, De haruspicum responsis, Pro Plancio, Cambridge, MA, 1923.

Cicero, The Verrine Orations, trans. L. H. G. Greenwood, 2 vols., Cambridge, MA, 1928-1935.

Cicero, The Speeches: Pro Caelio, De provinciis consularibus, Pro Balbo, trans.

R. Gardner, rev. ed., Cambridge, MA, 1965.

Cicero, The Speeches: Pro Sestio, In Vatinium, trans. R. Gardner, Cambridge, MA, 1958.

Cicero, The Speeches: Pro lege Manilia, Pro Caecina, Pro Cluentio, Pro Rabirio Perduellinis, trans. H. Grose Hodge, Cambridge, MA, 1927.

Cicero, In Catilinam I-IV : Pro Murena, Pro Sulla, Pro Flacco, trans. C. Macdonald, Cambridge, MA, 1972. 
Cicero, Pro Publio Quinctio: Pro Sexto Roscio Amerino; Pro Quinto Roscio Comoedo; De lege agraria I, II, III, trans. J. H. Freese, Cambridge, MA, 1930.

Cicero, Speech on behalf of Publius Sestius, ed. R. A. Kaster, Oxford, 2006.

Cicero, Letters to Atticus, ed. and trans. D. R. Shackleton Bailey, 7 vols., Cambridge, 1965-70.

Cicero, Epistulae ad Quintum fratrem et M. Brutum, ed. D. R. Shackleton Bailey, Cambridge, 1980.

Cicero, Letters to friends, trans. D. R. Shackleton Bailey, 3 vols., Cambridge, MA, 2001.

Cicero, Letters to Quintus and Brutus; Letter fragments; Letter to Octavian; Invectives; Handbook of electioneering, trans. D. R. Shackleton Bailey, Cambridge, MA, 2002.

Diodorus Siculus, Library of History, trans. C. H. Oldfather et al., 12 vols., Cambridge, MA, 1946-67.

Dionysius of Halicarnassus, Roman Antiquities, trans. E. Cary, 7 vols., Cambridge, MA, 1937-50.

Ennius, The Tragedies: the fragments, ed. H. D. Jocelyn, Cambridge, 1967.

Ennius, The Annals of Q. Ennius, ed. O. Skutsch, Oxford, 1985.

Festus, De verborum significatu quae supersunt cum Pauli epitome, ed. W. M. Lindsay, Olms, 1913. 
Florus, Lucius Annaeus Florus, Epitome of Roman history. Cornelius Nepos, trans E. S. Forster and J. C. Rolfe, Cambridge, MA, 1929.

Fronto, M. Cornelii Frontonis Epistulae, ed. van den Hout, Leipzig, 1988.

Fronto, Correspondence [of Marcus Cornelius Fronto] with Marcus Aurelius Antoninus, Lucius Verus, Antonius Pius, and various friends, 2 vols., trans. C. R. Haines, Cambridge, MA, 1919-1920.

Gellius, A. Gellii Noctes Atticae, ed. P. K. Marshall, Oxford, 1968.

Gellius, Attic Nights, 3 vols., ed. J. C. Rolfe, Cambridge, MA, 1978-1984.

Greenidge, A. H. J. and A. M. Clay, Sources for Roman History, 133-70 BC, rev. ed. by E. W. Gray, Oxford, 1960.

Inscriptiones Latinae Liberae Rei Publicae, ed. A. Degrassi, Florence, Fasc. I 1957, Fasc. II, 1963.

Inscriptiones Latinae Selectae, ed. H. Dessau, 3 vols in 5, Berlin, 1892-1916.

Livy, Titi Livi: Ab Urbe Condita I-V, ed. R. M. Ogilvie, Oxford, 1974.

Livy, Titi Livi: Ab Urbe Condita VI-X, ed. R. S. Conway and C. F. Walters 1993, Oxford, 1993.

Livy, Titi Livi: Ab Urbe Condita XXI-XXX, ed. C. F. Walters and R. S. Conway, 2 vols., Oxford, 1993.

Livy, Titi Livi: Ab Urbe Condita XXXI-XXXV, ed. A. H. McDonald, Oxford, 1965.

Livy, Titi Livi: Ab Urbe Condita XXXVI-XL, ed. P. G. Walsh, Oxford, 1999. 
Livy, Livy XII: Books XL-XLII, ed. and trans. E. T. Sage and A. C. Schlesinger, Cambridge, MA, 1964.

Malcovati, H. (ed.), Oratorum Romanorum Fragmenta, 2nd ed., Turin, 1955.

Mommsen, Th., et al. (eds.), Corpus Inscriptionum Latinarum, 17 vols, Berlin, 1863-2006.

Nepos, Lucius Annaeus Florus, Epitome of Roman history. Cornelius Nepos, trans E. S. Forster and J. C. Rolfe, Cambridge, MA, 1929.

Peter, H., Vetorum Historicorum Romanorum Reliquae, Leipzig, 1870.

Pliny the Elder, Natural History Books 1-19, trans. H. Rackham, 5 vols. Cambridge, MA, 1938-1950.

Pliny the Elder, Natural History Books 20-32, trans. W. Jones, 3 vols., Cambridge, MA, 1951-1963.

Pliny the Elder, Natural History Books 33-35, trans. H. Rackham, Cambridge, MA, 1952.

Pliny the Elder, Natural History Books 36-37, trans. D. E. Eichholz, Cambridge, MA, 1962.

Plutarch, Vitae Parallelae, eds. Cl. Lindskog et K. Ziegler, 2 vols., Stuttgart, 1994.

Polybius, Historiae, eds. L. Dindorf and Th. Büttner-Wobst, 3 vols, Leipzig, 1889-1905.

Quintilian, Institutionis oratoriae libri duodecim, ed. M. Winterbottom, 2 vols., Oxford, 1970. 
Riccobono, S. et al. (eds.), Fontes Iuris Romani Antejustiniani, 2nd ed., Florence, 1941.

Sallust, C. Sallusti Crispi Historiarum reliquiae B. Maurenbrecher (ed), Stuttgart, 1893.

Sallust, The Histories, 2 vols., translated with an introduction and commentary by P. McGushin, Oxford, 1992.

Sallust, Sallust, trans. J. C. Rolfe, Cambridge, MA, 1971.

Sallust, C. Sallusti Crispi Catilina, Iugurtha, Historiarum Fragmenta Selecta, Appendix Sallustiana, ed. L. D. Reynolds, Oxford, 1991.

Seneca the Elder, Declamations, trans. M. Winterbottom, 2 vols., Cambridge, MA, 1974.

Sherwin, W. K. (trans.), De viris illustribus urbis Romae, Oklahoma, 1973.

Stangl, T. (ed.), Ciceronis Orationum Scholiastae, Vienna, 1912,

Suetonius, De vita Caesarum libri viii, ed. M. Ihm, Leipzig, 1908.

Suetonius, The Twelve Caesars, trans. R. Graves, revised with introduction by M. Grant, Harmondsworth, 1979.

Tacitus, Annales, ed. H. Heubner, Leipzig, 1983.

Tacitus, Dialogus de oratoribus, ed. M. Winterbottom, Oxford, 1975.

Thesaurus Linguae Latinae, Leipzig, 1900-

Valerius Maximus, Factorum et dictorum memorabilium libri IX, ed. J. Briscoe, 2 vols., Stuttgart, 1998. 
Varro, Varro on the Latin Language, trans. R. G. Kent, 2 vols., Cambridge, MA, 1938.

Vellius Paterculus, Historiarum libri duo, ed. W. Smith, $2^{\text {nd }}$ updated ed., Leipzig, 1998.

\section{b) Commentaries}

Berry, D. H. (ed.), Cicero: Pro P. Sulla Oratio, Cambridge, 1996.

Briscoe, J., A Commentary on Livy, Books XXXI-XXXIII, Oxford, 1973.

Briscoe, J., A Commentary on Livy, Books XXXIV-XXXVII, Oxford, 1981.

Briscoe, J., A Commentary on Livy, Books 38-40, Oxford, 2008.

Carter, J. M. Julius Caesar: The Civil War, Book 3, Warminster, 1993.

Gabba, E., Appiani Bellorum Civilium Liber Primus, 2nd ed., Florence, 1967.

Jonkers, E. J., Social and Economic Commentary on Cicero's De Lege Agraria Orationes Tres, Leiden, 1959.

Kraus, C. S., Livy Ab Urbe Book VI, Cambridge, 1994.

MacKendrick, P., The speeches of Cicero : context, law, rhetoric, London, 1995.

Marshall, B. A., A Historical Commentary on Asconius, New York, 1985.

Oakley, S. P., A Commentary on Livy, Books VI-X, 4 vols, Oxford, 19962005 
Ogilvie, R. M., A Commentary on Livy, Books 1-5, Oxford, 1965.

Pocock, L. G., A Commentary on Cicero, In Vatinium, London, 1926.

Ramsey, J. T., Sallust's Bellum Catilinae, 2nd ed., Oxford, 2007.

Shackleton Bailey, D. R. (ed.), Cicero's Letters to Atticus, 7 vols., Cambridge, 1965-1970.

Shackleton Bailey, D. R. (ed.), Cicero Epistulae ad Familiares, 2 vols., Cambridge, 1977.

Shackleton Bailey, D. R. (ed.), Epistulae ad Quintum Fratrem et M. Brutum, Cambridge, 1980.

Walbank, F. W., A Historical Commentary on Polybius, 3 vols, Oxford, 19571979.

Walsh, P. G., Livy Book XL (182-179), Warminster, 1996. 


\section{$\underline{\text { Secondary sources }}$}

Adcock, F. E., Roman Political Ideas and Practice, Ann Arbor, 1964.

Aldrete, G. S., Gestures and Acclamation in Ancient Rome, Baltimore and London, 1999.

Alexander, M. C., Trials in the Late Republic, 149 B.C.-50 B.C., Toronto, 1990.

Alexander, M. C., "Review of F. Millar: The Crowd in Rome in the Late Republic", AJPh 121 (2000), 162-165.

Alexander, M. C., The Case for the Prosecution in the Ciceronian Era, Ann Arbor, 2002.

Alföldy, G., The Social History of Rome, trans. D. Braund and F. Pollock, rev. ed., London, 1988.

Allen Jr., W., “In Defence of Catiline” CJ 34 (1938), 70-85.

Allen Jr., W., “Cicero's House and Libertas”, TaPhA 75 (1944), 1-9.

Ando, C., Roman Religion, Edinburgh, 2003.

Andreau, J., Banking and Business in the Roman World, trans. J. Lloyd, Cambridge, 1999.

Apter, D. E. and N. Sawa, Against the State: Politics and Social Protest in Japan, Cambridge, MA, 1984.

Arblaster, A., Democracy, Minneapolis, 1994. 
Arena, V., “Not So Democratic After All? Review of H. Mouritsen: Plebs and Politics in the Late Roman Republic", CR 53 (2003), 158-159.

Arendt, H., On Revolution, Harmondsworth, 1963.

Astin, A. E., “Leges Aelia et Fufia”, Latomus 23 (1964), 421-445.

Astin, A. E., Scipio Aemilianus, Oxford, 1967.

Astin, A. E., Cato the Censor, Oxford, 1978.

Astin, A. E., “Censorship in the Late Republic”, Historia 34 (1985a), 17590.

Astin, A. E., “Cicero and the censorship”, CPh 80 (1985b), 233-239.

Astin, A. E., "Roman Government and Politics, 200-134 BC", ch. 6 in CAH II, vol. 8, 1989, 163-196.

Astin, A. E., "The role of the censors in Roman economic life", Latomus 49 (1990), 20-36.

Atkinson, N., Adventures in Democracy: a History of the vote in New Zealand, Dunedin, 2003.

Badian, E., “Lex Acilia Repetundarum”, AJPh 75 (1954), 374-384.

Badian, E., Foreign Clientelae (264-70 B. C.), Oxford, 1958.

Badian, E., “From the Gracchi to Sulla”, Historia 11 (1962a), 197-245.

Badian, E., “Waiting for Sulla”, JRS 52 (1962b), 47-61.

Badian, E., "Review of Lily Ross Taylor: The Voting Districts of the Roman Republic", JRS 52 (1962c): 200-210. 
Badian, E., "M. Porcius Cato and the annexation and early administration of Cyprus", JRS 55 (1965): 110-121.

Badian, E., “The Early Historians”, in T. A. Dorey (ed.), Latin Historians, London, 1966., 1-38.

Badian, E., Roman Imperialism in the Late Republic, Pretoria, 1967.

Badian, E., “Quaestiones Variae”, Historia 18 (1969), 447-491.

Badian, E., Lucius Sulla: the Deadly Reformer, Sydney, 1970.

Badian, E., "Tiberius Gracchus and the Beginning of the Roman Revolution", ANRW1.1 (1972a), 668-731.

Badian, E., Publicans and Sinners, Oxford, 1972 b.

Badian, E., “Review of A. H. Bernstein, Tiberius Sempronius Gracchus. Tradition and Apostasy", AJPh 100 (1979), 452-458.

Badian, E., “The silence of Norbanus: a note on provincial quaestors under the Republic", AJPh 104 (1983), 156-171.

Badian, E., “The Death of Saturninus”, Chiron 14 (1984): 101-147.

Badian, E., “The case of cowardly tribune C.T.H.R.E. on E.H.L.N.R.”, The Ancient History Bulletin 3 (1989), 78-107.

Badian, E., “The scribae of the Roman Republic”, Klio 71 (1989), 582-603.

Badian, E., “The consuls, 179-49 BC”, Chiron 20 (1990), 371-413.

Badian, E., "Tribuni plebis and res publica”, in J. Linderski (ed.), Imperium sine fine - T. R. S. Broughton and the Roman Republic, Stuttgart, 1996, 187-212. 
Balot, R.K., (ed.), A Companion to Greek and Roman Political Thought, Oxford, 2009.

Balsdon, J. P. V. D., “Sulla Felix”, JRS 41 (1951), 1-10.

Balsdon, J. P. V. D., "Roman History, 58-56 BC: three Ciceronian problems", JRS 47 (1957), 15-20.

Balsdon, J. P. V. D., “Roman History, 65-50 BC: Five Problems”, JRS 52 (1962), 134-141.

Balsdon, J. P. V. D., “The Commentariolum Petitionis”, CQ 13 (1963), 242-250.

Balsdon, J. P. V. D., “Fabula Clodiana”, Historia 15 (1966), 65-73.

Barber, B. R., Jihad vs. McWorld: How Globalism and Tribalism are Reshaping the World, New York, 1996.

Beard, M., "Priesthood in the Roman Republic", in M. Beard and J.

North (eds.), Pagan Priests: Religion and Power in the Ancient World, London, 1990, 17-48.

Beard, M. "An open Forum? Review of F. Millar: The Crowd in Rome in the Late Republic", Times Literary Supplement (May 28, 1999), 3-4.

Beard, M. The Roman Triumph, Cambridge, MA, 2007.

Beard, M. and J. North (eds.), Pagan Priests: Religion and Power in the Ancient World, London, 1990.

Beard, M. et al. (eds.), Literacy in the Roman World, Ann Arbor, 1991. 
Beard, M. and M. Crawford, Rome in the late Republic : problems and interpretations, 2nd ed., London, 1999.

Beard, M., J. North and S. Price (eds.), Religions of Rome, 2 vols., Cambridge, 1998.

Beetham, D., S. Bracking, I. Kearton, N. Vittal and S. Weir (eds.), The State of Democracy: Democracy Assessments in Eight Nations Around the World, The Hague, 2002.

Bell, A. J. E., “Cicero and the spectacle of power”, JRS 87 (1997), 1-22.

Bell, A. J. E., "Review of F. Millar, The Crowd in Rome in the Late Republic", JRS 90 (2000): 220-221.

Bell, A. J. E. Spectacular Power in the Greek and Roman City, Oxford, 2004.

Berlin, I., Four Essays on Liberty, Oxford, 1969.

Bernstein, A. H., Tiberius Sempronius Gracchus: Tradition and Apostasy, Ithaca, 1978.

Berry, D. H., “Equester Ordo Tuus Est: Did Cicero win his cases because of his support for the Equites?", CQ 53 (2003), 222-234.

Berry, D. H., “A Ciceronian Companion. Review of J. M. May (ed.), Brill's Companion to Cicero: Oratory and Rhetoric", CR 54 (2004), 8991.

Best, E. E., “Literacy and Roman voting”, Historia 23 (1974), 428-438.

Billows, R., "Legal fiction and political reform at Rome in the early second century B.C.", Phoenix 43 (1989), 112-133. 
Bleicken, J., Das Volkstribunat der klassichen Republik, Munich, 1955.

Bleicken, J., "Das römische Volkstribunat: Versuch einer Analyse seiner politischen Funktion in republikanischer Zeit", Chiron 11 (1981), 87-108.

Boren, H. C., Roman Society: A Social, Economic and Cultural History, $2^{\text {nd }}$ ed., Lexington, MA, 1992.

Botsford, G. W., The Roman Assemblies from their Origin to the End of the Republic, New York, 1909.

Bowman, A. K. and G. Woolf (eds.) Literacy and Power in the Ancient World, Cambridge, 1994.

Brennan, T. C., The Praetorship in the Roman Republic, 2 vols., Oxford, 2000.

Briscoe, J., “Review of R. Feig Vishnia: State, Society, and Popular Leaders in Mid-Republican Rome 241-167 BC", JRS 87 (1997), 281.

Broadhead, W., "Colonization, Land Distribution, and Veteran Settlements", in P. Erdkamp (ed.), in A Companion to the Roman Army, Malden, MA, 2007, 148-163.

Broughton, T. R. S., The Magistrates of the Roman Republic, 3 vols., New York, 1951-1986.

Broughton, T. R. S., "Senate and Senators of the Roman Republic: The Prosopographical Approach", ANRW1.1 (1972), 250-265. 
Broughton, T. R. S., "Candidates defeated in Roman elections: some ancient Roman 'also-rans'”, TAPA 81 (1991), 1-64.

Brunt, P. A., "The army and the land in the Roman revolution", JRS 52 (1962), 69-86.

Brunt, P. A., "Review of D. C. Earl, Tiberius Gracchus”, Gnomon 37 (1965), 189-192.

Brunt, P. A., “The Roman mob”, PEP 35 (1966), 3-27.

Brunt, P. A., "Review of Ch. Meier, Res Publica Amissa", JRS 58 (1968), 229-232.

Brunt, P. A., Italian Manpower 225 BC-AD 14, Oxford, 1971a.

Brunt, P. A., Social Conflicts in the Roman Republic, London, $1971 \mathrm{~b}$.

Brunt, P. A., "Free labour and public works at Rome”, JRS 70 (1980), 81100.

Brunt, P. A., “Nobilitas and Novitas”, JRS 72 (1982), 1-17.

Brunt, P. A., The Fall of the Roman Republic and Related Essays, Oxford, 1988.

Burckhardt, L. A., "The political elite of the Roman Republic: comments on recent discussion of the concepts of nobilitas and homo novus", Historia 39 (1990), 77-99.

Burton, G., "Review of H. Mouritsen, Plebs and Politics in the Late Roman Republic", JRS 93 (2003), 367.

Butler, S., The Hand of Cicero, London and New York, 2002. 
Cairns, F and E. Fantham (eds.), Caesar Against Liberty? Perspectives on his Autocracy, Cambridge, 2003.

Canetti, E. Crowds and Power, trans. C. Stewart, Harmondsworth, 1973.

Cape, R. W. Jr., 'Cicero's consular speeches', in J. M. May (ed.), Brill's Companion to Cicero: Oratory and Rhetoric, Leiden, 2002, 113-158.

Carney, T. F., A Biography of C. Marius, Chicago, 1970.

Cary, M. and H. H. Scullard, A History of Rome Down to the Reign of Constantine, $3^{\text {rd }}$ ed., London and Basingstoke, 1975.

Champlin, E. J., “The Suburbium of Rome”, AJAH 7 (1982), 97-117.

Chapple, G., 1981: The Tour, Wellington, 1984.

Chrissanthos, S. G., "Freedom of Speech and the Roman Republican Army", in I. Sluiter and R. M. Rosen (eds.), Free Speech in Classical Antiquity, Leiden, 2004, 341-367.

Claridge, A., Rome: an Oxford Archaeological Guide, Oxford, 1998.

Clarke, J. R. Art in the lives of ordinary Romans: visual representation and non-elite viewers in Italy, 100 B.C. - A.D. 315, Berkeley, 2003.

Clauss, J. J., “The ignoble consistency of M. Caelius Rufus”, Athenaeum 68 (1990), 531-540.

Coarelli, F., Il Foro Romano II: periodo republicano e augusteo, 2nd edn., Roma, 1986. 
Connerty, V., "Review of A. Drummond, Law, Politics and Power: Sallust and the execution of the Catilinarian conspirators," JRS 87 (1997), 285.

Connerty, V., "Publius Clodius Pulcher. Review of W. J. Tatum: The Patrician Tribune Publius Clodius Pulcher", CR 50 (2000), 514-516.

Connolly, J., The State of Speech: Rhetoric and Political Thought in Ancient Rome, Princeton, 2007.

Corbeill, A., Controlling Laughter: Political Humor in the Late Roman Republic, Princeton, 1996.

Corbeill, A., “Political Movement: Walking and Ideology in Republican Rome," in The Roman Gaze, D Fredrick (ed.), Baltimore, 2002, 182215.

Corbeill, A., Nature Embodied: Gesture in Ancient Rome, Princeton, 2004.

Cornell, T. J., "The Failure of the plebs", in Tria Corda: scritti in onore di Arnaldo Momigliano (ed. E. Gabba), Como, 1983, 101-120.

Cornell, T. J., "The Value of the Literary Traditon Concerning Archaic Rome", in K. A. Raaflaub (ed.) Social Struggles in Archaic Rome: New Perspectives on the Conflict of the Orders. Berkeley, 1986, 52-76.

Cornell, T. J., “The recovery of Rome”, ch. 7 in CAH II, vol. 7 part 2, 1989, 309-350.

Cornell, T. J., "Rome: the history of an anachronism", in A. Molho, K. Raaflaub and J. Emlen (eds.), City-States in Classical Antiquity and Medieval Italy, Stuttgart, 1991, 53-68. 
Cornell, T. J., The Beginnings of Rome, London, 1995.

Cornell, T. J. and K. Lomas, Urban Society in Roman Italy, London, 1995.

Craig, C. P. "A survey of selected recent work on Cicero's rhetorica and speeches", in J. M. May (ed.), Brill's Companion to Cicero: Oratory and Rhetoric, Leiden, 2002a, 503-531.

Craig, C. P. "Review of A. M. Riggsby, Crime and Community in Ciceronian Rome", JRS 92 (2002b), 230.

Craig, C. P., "Cicero as Orator", in W. Dominik, and J. Hall (eds.), A Companion to Roman Rhetoric, Malden, MA, 2007: 264-284.

Crawford, J. W. (ed.), M. Tullius Cicero: the Fragmentary Speeches, $2^{\text {nd }}$ ed., Atlanta, 1994.

Crawford, M. H., The Roman Republic, 2nd ed., Cambridge, MA, 1993

Crawford, M. H., Roman Republican Coinage, 2 vols., Cambridge, 1974.

Crawford, M. H., "Hamlet without the Prince: Review of E. S. Gruen, The Last Generation of the Roman Republic", JRS 66 (1976), 214-217.

Crawford, M. H., Coinage and Money under the Roman Republic, Berkeley, 1985.

Crawford, M. H. (ed.), Roman Statutes, BICS Suppl. 64, 2 vols., London, 1996.

Crawford, M. H., “Republican Legislation. Review of K. Sandberg: Magistrates and Assemblies. A Study of Legislative Practice in Republican Rome", CR 54 (2004), 171-172. 
Dahl, R. A., Polyarchy: Participation and Opposition, New Haven, 1971.

Dahl, R. A., Democracy and its Critics, New Haven, 1989.

Dahl, R. A., On Democracy, New Haven, 1998.

Dahl, R. A., How Democratic is the American Constitution? New Haven and London, 2002.

Dahl, R. A., I. Shapiro and J. A. Cheibub (eds.), The Democracy Sourcebook, Cambridge, MA and London, 2003.

De Blois, L., The Roman Army and Politics in the First Century B.C., Amsterdam, 1987.

De Blois, L., "Army and General in the Late Roman Republic", in P. Erdkamp (ed.), A Companion to the Roman Army, Malden, MA, 2007, 164-179.

De Ligt, L., "Poverty and Demography: The Case of the Gracchan Land Reforms", Mnemosyne 57 (2004): 725-757.

De Ligt, L., "Roman Manpower and Recruitment During the Middle Republic", in P. Erdkamp (ed.), A Companion to the Roman Army, Malden, MA, 2007, 114-131.

De Ligt, L. de and S. Northwood (eds.), People, land, and politics: demographic developments and the transformation of Roman Italy 300 $B C-A D$ 14, Leiden, 2008. 
Develin, R., "The third century reform of the comitia centuriata", Athenaeum 56 (1978), 346-377.

Develin, R., Patterns in Office-Holding, 366-49 B.C., Brussels, 1979.

Develin, R., The Practice of Politics at Rome 366-167 B.C., Brussels, 1985.

Dominik, W. and J. Hall (eds.), A Companion to Roman Rhetoric, Malden, MA, 2007.

Drummond, A., "Early Roman clients", in A. Wallace-Hadrill (ed.), Patronage in Ancient Society, London, 1989a, 89-115.

Drummond, A., "Rome in the fifth century II: the citizens community", ch. 5 in CAH II vol. 7 part 2, 1989b, 172-242.

Drummond, A., Law, Politics and Power: Sallust and the execution of the Catilinarian conspirators, Stuttgart, 1995.

Drummond, A., "Rullus and the Sullan Possessores", Klio 82 (2000), 126153.

Duff, A., Freedmen in the Roman Empire, Oxford, 1928.

Dunn, J. (ed.), Democracy: The Unfinished Journey, 508 BC to AD 1993, Oxford, 1992.

Earl, D. C., The Political Thought of Sallust, Cambridge, 1961.

Earl, D. C., Tiberius Gracchus. A Study in Politics, Brussels, 1963.

Earl, D. C., The Moral and Political Tradition of Rome, Ithaca, N. Y., 1967. 
Eck, W., "Senatorial self-representation: developments in the Augustan period", in F. Millar and E. Segal (eds.), Caesar Augustus. Seven Aspects, Oxford, 1984, 129-167.

Eckstein, A. M., Senate and General: Individual Decision-Making and Roman Foreign Relations, 264-194 B.C., Berkley and Los Angeles, 1987.

Eder, W., “The Augustan principate as binding link”, in K. Raaflaub and M. Toher (eds.), Between Republic and Empire. Interpretation of Augustus and his Principate, Berkeley, 1990, 71-122.

Eder, W., "Who Rules? Power and Participation in Athens and Rome", in A. Molho, K. Raaflaub and J. Emlen (eds.), City-States in Classical Antiquity and Medieval Italy, Stuttgart, 1991, 169-196.

Edwards, C. and G. Woolf (eds.), Rome the Cosmopolis, Cambridge, 2003.

Ehrenberg, V and A. H. M. Jones (eds.), Documents illustrating the Reigns of Augustus and Tiberius, Oxford, 1949.

Epstein, D. F., Personal Enmity in Roman Politics, 218-43 BC, London, 1987.

Erdkamp, P. (ed.), A Companion to the Roman Army, Malden, MA, 2007.

Erskine, A., ‘Walbank's Collected Papers. Review of F. W. Walbank: Polybius, Rome and the Hellenistic World. Essays and Reflections", CR 54 (2004), 166-167.

Evans, J. D., The Art of Persuasion: Political Propaganda from Aeneas to Brutus, Ann Arbor, 1992. 
Evans, J. K., "Resistance at Home: the Evasion of Military Service in Italy During the Second Century B.C.", in T. Yuge and M. Doi (eds.) Forms of Control and Subordination in Antiquity, Leiden, 1988: 121140.

Evans, J. K., War, Women and Children, London, 1991.

Evans, R. J., "Consuls with a Delay between the Praetorship and the Consulship", AHB 4 (1990), 65-71.

Evans, R. J., "Candidates and Competition in Consular Elections at Rome between 218 and 49 BC", Acta Classica 34 (1991), 111-136.

Evans, R. J., Gaius Marius. A Political Biography, Pretoria, 1994.

Fantham, E., “The Trials of Gabinius in 54 B.C.”, Historia 24 (1975), 425443.

Feig Vishnia, R., State, Society, and Popular Leaders in Mid-Republican Rome 241-167 BC, London, 1996.

Feldman, N., After Jihad: America and the Struggle for Islamic Democracy, New York, 2003.

Ferray, J. -L., “Rogatio Servilia Agraria”, Athenaeum 56 (1988), 141-64.

Finley, M. I., Politics in the Ancient World, Cambridge, 1983.

Finley, M. I., Democracy Ancient and Modern, 2nd ed., London, 1985.

Fischer, S. R., A History of the Pacific Islands, Basingstoke, 2002. 
Flaig, E., “Entscheidung unde Konsens. Zu den Feldern der politischen Kommunikation zwischen Aristokratie und Plebs", in M. Jehne (ed.), Demokratie in Rom? Die Rolle des Volkes in der Politik der römischen Republik, Stuttgart, 1995, 77-127.

Flaig, E., Ritualisierte Politik. Zeichen, Gesten und Herrschaft in Alten Rom. Göttingen, 2003.

Flower, H., Ancestor Masks and Aristocratic Power in Roman Culture, Oxford, 1996.

Fontana, B., C. Nederman, G. Remer (eds.), Talking Democracy: Historical Perspectives on Rhetoric and Democracy, Pennsylvania, 2004.

Foreman, Sh., "The significance of participation: peasants in the politics of Brazil", in M. A. Seligson and J. A. Booth (eds.), Political Participation in Latin America, vol. 2: Politics and the Poor, New York, 1979, 36-50.

Forsythe, G., The Historian L. Calpurnius Piso Frugi and the Roman Annalistic Tradition. Lanham, MD, 1994.

Forsythe, G., Livy and Early Rome. A Study in Historical Method and Judgment. Stuttgart, 1999.

Forsythe, G., A Critical History of Early Rome. From Prehistory to the First Punic War. Berkeley, 2005.

Foucault, M., Discipline and Punish: The Birth of the Prison, New York, 1977. 
Foucault, M., “The Subject and Power”, Critical Inquiry 8 (1982), 777-95.

Frank, T., An Economic History of Rome, 2nd rev. ed., London, 1927.

Frederiksen, M. W., "Caesar, Cicero and the problem of debt", JRS 56 (1966), 128-141.

Gabba, E., Republican Rome. The Army and the Allies, trans. P. J. Cuff, Berkeley, 1976.

Gabba, E., "Review of C. Nicolet, The World of the Citizen”, JRS 67 (1977), 192-194.

Gabba, E., Dionysius and The History of Archaic Rome, Berkeley, 1991.

Gabba, E., "Rome and Italy: The Social War", ch. 4 in CAH II vol. 9, 1994, 104-128.

Gabba, E., “Democrazia a Roma”, Athenaeum 75 (1997), 266-271.

Gallie, W. B., Philosophy and the Historical Understanding, London, 1964.

Garnsey, P. D. A., "Peasants in Ancient Roman Society", in Garnsey, P. D. A., Cities, Peasants and Food in Classical Antiquity: Essays in Social and Economic History, (edited with addenda by W. Scheidel), Cambridge, 1998, pp. 91-106 = Journal of Peasant Studies 3 (1976), 221-235.

Garnsey, P. D. A., “Where did Italian peasants live?”, PCPhS 25 (1979), 125. 
Garnsey, P. D. A. (ed.), Non-Slave Labour in the Greco-Roman World, Cambridge, 1980.

Garnsey, P. D. A., "Non-Slave Labour in the Roman World", in P. D. A. Garnsey (ed.) Non-Slave Labour in the Greco-Roman World, Cambridge, 1980, 34-47.

Garnsey, P. D. A., Famine and Food Supply in the Graeco-Roman world: responses to risk and crisis, Cambridge, 1988.

Garnsey, P. D. A., Cities, Peasants and Food in Classical Antiquity: Essays in Social and Economic History, (edited with addenda by W. Scheidel), Cambridge, 1998.

Garnsey, P. D. A. and D. Rathbone, "The Background to the Grain Law of Gaius Gracchus", JRS 75 (1985), 20-25.

Garnsey, P. D. A and G. Woolf, "Patronage and the rural poor in the Roman world", in A. Wallace-Hadrill (ed.), Patronage in Ancient Society, London, 1989, 153-170.

Gelzer, M., The Roman Nobility, trans. R. Seager, Oxford, 1969 (German ed. 1912).

Gelzer, M., Caesar: Politician and Statesman, trans. P. Needham, $6^{\text {th }}$ ed., Cambridge, MA, 1968.

Giovannini, A., “Catilina et le problème des dettes”, in I. Malkin and Z. W. Rubinsohn (eds.), Leaders and Masses in the Roman World. Studies in Honor of Zvi Yavetz, Leiden, 1995, 15-32. 
Goldsworthy, A. The Roman Army at War, 100 BC to 200 AD, Oxford, 1996.

Gordon, A. E., Illustrated Introduction to Latin Epigraphy, Berkeley, 1983.

Grant, A. R., The American Political Process, 7th edn., New York, 2003.

Gregory, A. P., "'Powerful images': responses to portraits and the political uses of images in Rome", JRA 7 (1994): 80-99.

Grieve, L. G., "Livy 40.51 .9 and the Centuriate Assembly", CQ 35 (1985a), 417-29.

Grieve, L. G., "The reform of the comitia centuriata”, Historia 34 (1985b), 278-309.

Griffin, M., “The tribune C. Cornelius”, JRS 63 (1973), 196-213.

Griffin, M., "Review of S. Butler, The Hand of Cicero", JRS 93 (2003), 364365.

Gruen, E. S., “The Lex Valeria”, JRS 55 (1965), 59-73.

Gruen, E. S., “P. Clodius: instrument or independent agent?”, Phoenix 20 (1966), 120-30.

Gruen, E. S., Roman Politics and the Criminal Courts, 149-78 B.C., Cambridge, MA, 1968.

Gruen, E. S., The Last Generation of the Roman Republic, Berkeley, 1974.

Gruen, E. S., "The exercise of power in the Roman republic", in A. Molho, K. Raaflaub and J. Emlen (eds.), City-States in Classical Antiquity and Medieval Italy, Stuttgart, 1991, 251-267. 
Gruen, E. S., Culture and National Identity in Republican Rome, Ithaca, N. Y., 1992.

Gruen, E. S., "Review of Cambridge Ancient History, Second Edition, Volume IX", CJ 91 (1995), 71-75.

Gruen, E. S., "The Roman oligarchy: image and perception", in J. Linderski (ed.), Imperium sine fine - T. R. S. Broughton and the Roman Republic, Stuttgart, 1996, 215-234.

Gruen, E. S., "Review of F. Millar: The Crowd in Rome in the Late Republic", CPh 95 (2000), 236-240.

Habicht, C., Cicero the Politician, Baltimore, 1990.

Hall, U., “Voting procedure in Roman assemblies”, Historia 13 (1964), 267-306.

Hall, U., "Greeks and Romans and the secret ballot", in Owls to Athens Essays On Classical Subjects Presented to Sir Kenneth Dover, Oxford, 1990, 191-199.

Hardy, E. G., The Catilinarian Conspiracy in its Context: a Re-study of the Evidence, Oxford, 1924.

Harries, J., "Review of M. C. Alexander: The Case for the Prosecution in the Ciceronian Era", JRS 94 (2004), 237 f.

Harris, B. F. (ed.), Auckland Classical Essays, Auckland, 1970. 
Harris, W. V., "Review of E. Badian: Publicans and Sinners", AJPh 96 (1975), 433-436.

Harris, W. V., “The development of the quaestorship, 267-81 BC”, CQ 26 (1976), 92-106.

Harris, W. V., War and Imperialism in Republican Rome 327-7- B.C., Oxford, 1979.

Harris, W. V., "On defining the political culture of the Roman Republic", CPh 85 (1990), 288-294.

Hawthorn, J. R., “The senate after Sulla”, G \& R 9 (1962), 53-60.

Heikkilä, K., "Lex non iure rogata: Senate and the Annulment of Laws in the Late Roman Republic", in U. Paananen (ed.), Senatus Populusque Romanus. Studies in Roman Republican Legislation, Helsinki, 1993, 117-142.

Hemelrijk, E. A., "Women's demonstrations in Republican Rome”, in J. Blok and P. Mason (eds.), Sexual Asymmetry. Studies in Ancient Society, Amsterdam, 1987, 217-240.

Henderson, J. and P. Bellamy, Democracy in New Zealand, Christchurch, 2002.

Henderson, M. I., “De Commentariolo Petitionis”, JRS 40 (1950), 8-21.

Henderson, M. I., "The establishment of the 'equester ordo'”, JRS 53 (1963), 61-72. 
Hendrickson, G. L., "On the authenticity of the Commentariolum Petitionis of Quintus Cicero", AJP 13 (1892), 200-212.

Hill, H., The Roman Middle Class in the Republican Period, Oxford, 1952.

Hirst, J. B., Australia's Democracy: A Short History, Crow's Nest, 2002.

Hobsbawm, E., Primitive Rebels, New York, 1965.

Hölkeskamp, K.-J., "Conquest, competition and consensus: Roman expansion in Italy and the rise of the nobilitas", Historia 42 (1993), 12-39.

Hölkeskamp, K.-J., “Oratoris maxima scaena: Reden vor dem Volk in der politischen Kultur der Republik", in M. Jehne (ed.), Demokratie in Rom? Die Rolle des Volkes in der Politik der römischen Republik, Stuttgart, 1995, 11-49.

Hölkeskamp, K., 'The Roman Republic: Government of the People, by the People, for the People?', SCI 19 (2000), 203-223.

Hölkeskamp, K.-J., Rekonstruktionen einer Republik, Munich, 2004.

Hölkeskamp, K.-J., Senatus Populusque Romanus, Stuttgart, 2004.

Hölkeskamp, K.-J., “Die Enstehung der Nobilitaat”, in K.-J. Hölkeskamp Senatus Populusque Romanus, Stuttgart, 2004, 49-83.

Hopkins, K., Conquerors and Slaves, Cambridge, 1978.

Hopkins, K., "Taxes and Trade in the Roman Empire (200 B.C. - A.D. 400)", JRS 70 (1980), 101-125.

Hopkins, K., Death and Renewal, Cambridge, 1983. 
Hopkins, K., “From Violence to Blessing: Symbols and Rituals in Ancient Rome", in A. Molho, K. Raaflaub and J. Emlen (eds.), City-States in Classical Antiquity and Medieval Italy, Stuttgart, 1991, 479-498.

Horsfall, N. The Culture of the Roman Plebs, London, 2003.

Howarth, D., A. J. Norval and Y. Stavrakakis (eds.), Discourse Theory and Political Analysis: Identities, Hegemonies and Social Change, Manchester, 2001.

Inoguchi, T, E. Newman and J. Keane (eds.), The Changing Nature of Democracy, Tokyo and New York, 1998.

Jackson, S. B. 'Marcus Caelius Rufus' Hermathena 126 (1979) 55-67.

Jehne, M., “Einführung: Zur Debatte um die Rolle des Volkes in der römischen Republik", in M. Jehne (ed.), Demokratie in Rom? Die Rolle des Volkes in der Politik der römischen Republik, Stuttgart, 1995a, $1-10$.

Jehne, M., “Die Beeinflussung von Entscheidungen durch 'Bestechung': Zur Funktion des Ambitus in der römischen Republik", in M. Jehne (ed.), Demokratie in Rom? Die Rolle des Volkes in der Politik der römischen Republik, Stuttgart, 1995b, 51-76. 
Johnson, T. and C. Dandeker, "Patronage - relation and system", in A. Wallace-Hadrill (ed.), Patronage in Ancient Society, London, 1989, 219-242.

Johnston, D., Roman Law in Context, Cambridge, 1999.

Jones, A. H. M., “The elections under Augustus”, JRS 45 (1955), 9-21.

Jones, A. H. M., Studies in Roman Government and Law, Oxford, 1960.

Jones, A. H. M., Criminal Courts of Roman Republic

Jongman, W., "Slavery and the growth of Rome", in C. Edwards and G. Woolf (eds.), Rome the Cosmopolis, Cambridge, 2003, 100-122.

Kaplan, A., Catiline: The Man and his Role in the Roman Revolution, New York, 1968.

Keaveney, A., Sulla, the last republican, 2nd ed., Oxford, 2005.

Keaveney, A., Rome and the unification of Italy, London, 1987.

Keaveney, A., Lucullus, Oxford, 1992.

Keaveney, A., The Army in the Roman Revolution, London, 2007.

Kelly, D. H., "Evidence for Legislation by Tribunes 81-70 B.C." in B. F. Harris (ed.) Auckland Classical Essays, Auckland, 1970, 133-142.

Keppie, L. Understanding Roman Inscriptions, London, 1991.

Kloppenborg, J. S., “Collegia and thiasoi: Issues in function, taxonomy and membership". In Voluntary associations in the Greco-Roman 
world, edited by J. S. Kloppenborg and S. G. Wilson, 16-30. London, 1996.

Kloppenborg, J. S. and S. G. Wilson (eds.) Voluntary associations in the Greco-Roman world. London, 1996.

Kühnert, B., "Populus Romanus und sentina urbis: zur Terminologie der plebs urbana der späten Republik bei Cicero", Klio 71 (1989), 432441.

Kühnert, B., Die Plebs Urbana der späten römischen Republik: ihre ökonomische Situation und soziale Structur, Innsbruck, 1991.

Lakoff, G., Moral politics : how liberals and conservatives think, Chicago, 2002.

Lane, J. and S. Ersson, Democracy : a comparative approach, New York, 2003.

Larsen, J. A. O., "The origins and significance of the counting of votes", CPh 44 (1949), 164-181.

Larsen, J. A. O., “The judgement of antiquity on democracy”, CPh 49 (1954), 1-14.

Larsen, J. A. O., Representative Government in Greek and Roman History, Berkeley, 1955. 
Last, H. M., "C. Gracchus" in S. A. Cook, F. E. Adcock and M. P. Charlesworth (eds.) The Cambridge Ancient History, ed. 1, vol. IX, Cambridge, 40-101.

Last, H. M., "Review of F. B. Marsh, A History of the Roman World", AJPh 58 (1937), 467-474.

Last, H. M., "Review-discussion of H. J. Haskell, This Was Cicero", JRS 33 (1943), 93-97.

Laurence, R., "Rumour and Communication in Roman Politics", GER 41 (1994), 62-74.

Lawson, S., Tradition versus democracy in the South Pacific : Fiji, Tonga, and Western Samoa, Melbourne, 1996.

Levick, B., "Morals, Politics and the Fall of the Roman Republic", GER 29 (1982), 53-62.

Lewis, C. and C. Short, A Latin Dictionary, Oxford, 1879.

Linderski, J. and A. Kaminska-Linderska, "A. Gabinius A. F. Capito and the first voter in the legislative comitia tributa", ZPE 12 (1973): 247 252.

Linderski, J., "Constitutional aspects of the consular electionsin 59 BC", Historia 14 (1965), 423-442.

Linderski, J., "Buying the vote: electoral corruption in the Late Republic", The AncW 11 (1985): 87-94.

Lintott, A. W., “Trinundinum”, CQ 15 (1965), 281-285. 
Lintott, A. W., “P. Clodius Pulcher - Felix Catilina?”, GER 14 (1967): 15769.

Lintott, A. W., “The Tribunate of P. Sulpicius Rufus”, CQ 21 (1971): 442453.

Lintott, A. W., "Imperial expansion and moral decline in the Roman Republic", Historia 21 (1972a), 626-638.

Lintott, A. W., "Provocatio: From the Struggle of the Orders to the Principate", ANRW1.2 (1972b), 226-267.

Lintott, A. W., “Cicero and Milo”, JRS 64 (1974), 62-78.

Lintott, A. W., "Democracy in the Middle Republic", ZRG 104 (1987), 3452.

Lintott, A. W., “Electoral Bribery in the Roman Republic”, JRS 80 (1990), $1-16$.

Lintott, A. W., Judicial Reform and Land Reform in the Roman Republic, Cambridge, 1992.

Lintott, A. W., "The crisis of the Republic: sources and source-problems", Ch. 1 in CAH II, vol. 9, 1994a, 1-15.

Lintott, A. W., "Political history, 146-96 B.C.", ch. 3 in CAH II, vol. 9, 1994b, 40-103.

Lintott, A. W., Violence in Republican Rome, 2 ${ }^{\text {nd }}$ ed., Oxford, 1999a.

Lintott, A. W., The Constitution of the Roman Republic. Oxford, 1999b. 
Lintott, A. W., “Legal Procedure in Cicero's Time” in J. Powell and J. Paterson (eds.), Cicero the Advocate, Oxford, 2004: 61-78.

Lo Cascio, E., "The size of the Roman population: Beloch and the meaning of the Augustan census figures", JRS 84 (1994), 23-40.

Lo Cascio, E., "Recruitment and the Size of the Roman Population from the Third to the First Century BCE," in W. Scheidel, Debating Roman Demography, Leiden, 2001: 111-137.

Lomas, K. and T. Cornell (eds.) Bread and Circuses: Euergetism and Municipal Patronage in Roman Italy, London, 2003.

Mackie, N. "Popularis Ideology and Popular Politics at Rome in the First Century B. C.", RhM 135 (1992), 49-73.

MacMullen, R., Roman Social Relations 50 BC to AD 284, New Haven and London, 1974.

MacMullen, R., “How many Romans voted?”, Athenaeum 58 (1980), 454457.

Madsen, D. W., The life and political career of Marcus Caelius Rufus, Univ. of Washington Seattle, 1981.

Marsh, F. B., A History of the Roman World, London, 1935.

Marshall, B. A., Crassus: A Political Biography, Amsterdam, 1976.

Marshall, B. A. and J. L. Beness, “Tribunician agitation and aristocratic reaction 80-71 B.C", Athenaeum 65 (1987), 361-378. 
Mattingly, H., “Property qualifications of Roman classes”, JRS 27 (1937), 99-107.

McClelland, J. S., The Crowd and the Mob from Plato to Canetti, London, 1989.

McDonald, W., “The Tribunate of Cornelius”, CQ 23 (1929): 196-208.

Meier, Ch., Res Publica Amissa, Frankfurt am Main, 3'rd ed., 1997.

Meier, Ch., Caesar, (trans. D. McLintock), London, 1982.

Messer, W. S., "Mutiny in the Roman Army. The Republic", CPh 15 (1920): 158-175.

Meyer, D. S., The Politics of Protest: Social Movements in America, Oxford, 2007.

Millar, F., "The political character of the classical Roman Republic, 200151 B.C.", JRS 74 (1984): 1-19.

Millar, F., "Politics, persuasion, and the plebs/people before the Social War (150-90 B.C.)", JRS 76 (1986): 1-11.

Millar, F., "Political power in mid-Republican Rome: Curia or comitium?: Review of K. Raaflaub (ed.) Social Struggles in Archaic Rome: New Perspectives on the Conflict of the Orders and K. -J. Hölkeskamp, Die Entstehung der Nobilität", JRS 79 (1989): 138-150.

Millar, F., "Popular politics at Rome in the Late Republic", in I. Malkin and J.W. Rubinsohn (eds.), Leaders and Masses in the Roman World. Studies in honour of Z. Yavetz, Leiden, 1995a, 91-113. 
Millar, F., "Roman libertas and civic freedom", Arethusa 28 (1995b), xx-xx. Millar, F., "The Last Century of the Republic: Whose History? Review of J. A. Crook. A. Lintott, and E. Rawson (eds.) The Cambridge Ancient History IX: The Last Age of the Roman Republic, 146-43 B.C.", JRS 85 (1995c), 236-243.

Millar, F., The Crowd in Rome in the Late Republic, Ann Arbor, 1998.

Millar, F., The Roman Republic in Political Thought, London, 2002.

Miller, R. (ed.), New Zealand Government and Politics, Oxford, 2003 (third edition).

Mitchell, R. E., “The Definition of patres and plebs: An End to the Struggle of the Orders", in K. A. Raaflaub (ed.) Social Struggles in Archaic Rome: New Perspectives on the Conflict of the Orders. Berkeley, 1986, 130-174.

Mitchell, R. E., Patricians and Plebeians, Ithaca, N.Y., 1990.

Mitchell, T. N., “The Volte-Face of P. Sulpicius Rufus in 88 BC”, CPh 70 (1975): 197-204.

Mitchell, T. N., Cicero: The Ascending Years, New Haven, 1979.

Mitchell, T. N., “The Leges Clodiae and Obnuntiatio”, CQ 36 (1986), 172-76.

Mitchell, T. N., Cicero: The Senior Statesman, New Haven, 1991.

Morgan, M. and J. Walsh, “Ti. Gracchus (Tr. Pl. 133 B.C.), The Numantine Affair, and the Deposition of M. Octavius", CPh. 73 (1978): 200-210. 
Morley, N., Metropolis and Hinterland, Cambridge, 1996.

Moore, M., Dude, Where's My Country? London, 2003.

Morstein-Marx. R. "Publicity, Popularity and Patronage in the Commentariolum Petitionis", ClAnt 17 (1998), 259-288.

Morstein-Marx, R. "Res Publica Res Populi. Review of A. Yakobson, Elections and Electioneering in Rome. A Study in the Political System of the Late Republic." SCI 19 (2000), 224-233.

Morstein-Marx, R. Mass Oratory and Political Power in the Late Roman Republic, Cambridge, 2004.

Mouritsen, H., Elections, Magistrates and Municipal Elite. Studies in Pompeian Epigraphy, Rome, 1988.

Mouritsen, H., Italian unification: a study in ancient and modern historiography, London, 1998.

Mouritsen, H., Plebs and Politics in the Late Roman Republic, Cambridge, 2001.

Mouritsen, H., “Freedmen and Decurions: Epitaphs and Social History in Imperial Italy" JRS 95 (2005), 38-63.

Mulgan, R., Democracy and Power in New Zealand, 2nd ed., Oxford, 1989.

Münzer, F., Roman Aristocratic Parties and Families, (trans. Thérèse Ridley), Baltimore, 1999 [= Römische Adelsparteien und Adelsfamilien, Stuttgart, 1920]. 
Nagle, D. B., “The Failure of the Roman Political Process in 133 B.C. Part 1: The Gracchan Constitution of 133 B.C", Athenaeum 48 (1970), 372-394.

Nagle, D. B., “The Failure of the Roman Political Process in 133 B.C. Part 2: The Crowded Schedule of 133 B.C.", Athenaeum 49 (1971), 111128.

Nagle, D. B., "Review of Vanderbroeck, Popular Leadership and Collective Behavior in the Late Roman Republic," American Historical Review 95 (1990): 144-145.

Nicolet, C., "Economy and Society, 133-43 B.C.", ch. 16 in CAH II, vol. 9, $1994,599-643$.

Nicolet, C., The World of the Citizen in Republican Rome, trans. P. S. Falla, London, 1980.

Nippel, W., “Policing Rome”, JRS 74 (1984), 20-29.

Nippel, W., Public Order in Ancient Rome, Cambridge, 1995.

Nippel, W., "Roman Voters. Review of A. Yakobson: Elections and Electioneering in Rome. A Study in the Political System of the Late Republic.", CR 50 (2000), 518-520.

Nisbet, R. G. M., “The Commentariolum Petitionis: some arguments against authenticity", JRS 51 (1964), 84-87.

North, J., “The Development of Roman Imperialism”, JRS 71 (1981), 1-9. 
North, J., “The Roman Counter-Revolution. Review of P. A. Brunt, The Fall of the Roman Republic", JRS 79 (1989), 151-156.

North, J., “Democratic Politics in Republican Rome”, PEP 126 (1990a), 321.

North, J., "Politics and aristocracy in the Roman Republic", CPh 85 (1990b), 277-87.

North, J., Roman Religion, Oxford, 2000.

North, J., "Postscript 2003", in R. Osborne (ed.) Studies in Ancient Greek and Roman Society, Cambridge, 2004, 156-158.

Ober, J., Mass and Elite in Democratic Athens, Princeton, 1989.

Ober, J. and C. Hedrick (eds.), Demokratia: a conversation on democracies, ancient and modern, Princeton, 1996.

Ogilvie, R. M., Early Rome and the Etruscans, London, 1976.

O'Gorman, E. "Cicero and the Written Word. Review of S. Butler: The Hand of Cicero"' CR 53 (2003): 346-347.

O'Kane, R. H. T., Paths to Democracy: Revolution and Totalitarianism, London, 2004.

O'Neill, P. "Going Round in Circles: Popular Speech in Ancient Rome", Cl Ant 22.1 (2003), 135-165.

Orlin, E. M., Temples, Religion and Politics in the Roman Republic, Leiden, 1997. 
Osborne, R. (ed.) Studies in Ancient Greek and Roman Society, Cambridge, 2004.

Paananen, U., Sallust's politico-social terminology; its use and biographical significance, Helsinki, 1972.

Paananen, U. et al. (ed.) Senatus Populusque Romanus: Studies in Roman Republican Legislation, Helsinki, 1993.

Parkins, H. M. (ed.), Roman Urbanism: beyond the Consumer City, London, 1997.

Parry, G., Political Elites. London, 1969.

Paterson, J., "Politics in the Late Republic", in T. P. Wiseman (ed.), Roman Political Life, Exeter, 1985, 21-43.

Paterson, J., "Review of A. Yakobson, Elections and Electioneering in Rome", JRS 92 (2002), 229.

Patterson, J. R., Landscapes and Cities: Rural Settlement and Civic Transformation in Early Imperial Italy. Oxford, 2006.

Paul, G. M., A Historical Commentary on Sallustus' Bellum Jugurthinum, Liverpool, 1984.

Pauly, A., G. Wissowa and W. Kroll Real-Encyclopädie der classischen Altertums-wissenschaft, Stuttgart and Munich, 1893-. 
Phillips, D. A., "Review of A. Yakobson: Elections and Electioneering in Rome: A Study in the Political System of the Late Republic", BMCR 07.02.2000.

Pina Polo, F., "Procedures and Functions of Civil and Military Contiones", Klio 77 (1995), 203-216.

Pina Polo, F., Contra Arma Verbis, Stuttgart, 1996.

Platner, S. B. and T. Ashby, A Topographical Dictionary of Ancient Rome, Oxford, 1929.

Pleket, H. W., "Commentary" in A. Molho, K. Raaflaub and J. Emlen (eds.), City-States in Classical Antiquity and Medieval Italy, Stuttgart, $1991,331-343$

Potter, D., et al. (eds.), Democratization, Malden, MA, 1997 (from classical times to the present)

Powell, A., "Roman Democracy. Review of F. Millar: The Crowd in Rome in the Late Republic", CR 50 (2000), 516-518.

Powell, J. and J. Paterson (eds.), Cicero the Advocate, Oxford, 2004.

Purcell, N., "The Apparitores: a study in social mobility", PBSR 51 (1983), 125-173.

Purcell, N., "The city of Rome and the plebs urbana in the late Republic", ch. 17 in CAH II, vol. 9, 1994, 644-688. 
Purcell, N., "Forum Romanum (the Republican period)", in E. M. Steinby (ed.), Lexicon topographicum urbis Romae, vol. 2, Rome, 1993-2000, 325-336.

Purcell, N., "Rome and its development under Augustus and his successors", ch. 15 in CAH II, vol. 10, 1996, 782-811.

Raaflaub, K. A. (ed.) Social Struggles in Archaic Rome: New Perspectives on the Conflict of the Orders. Berkeley, 1986.

Raaflaub, K. A. "Politics and Society in Fifth-Century Rome", Bilancio Critico su Roma Arcaica fra Monarchia e Repubblica, Rome, 1993.

Rahe, P. A., Republics Ancient and Modern, 3 vols., Chapel Hill, 1992.

Rapley, J., Globalization and Inequality: Neoliberalism's Downward Spiral, Boulder and London, 2004.

Rathbone, D. W., “The Slave Mode of Production in Italy”, JRS (1983), $160-168$.

Rathbone, D. W., "Review of J. Andreau, Banking and Business in the Roman World", JRS 91 (2001), 201-202.

Rawson, E., “The interpretation of Cicero's De Legibus”, ANRW 1.4 (1973), 334-356.

Rawson, E., Cicero: a Portrait, London, 1975.

Rawson, E., Roman Culture and Society, Oxford, 1991. 
Reilly, B. and E. Wainwright (2005) "The South Pacific" in S. Chesterman et al. (eds.), Making States Work: State Failure and the Crisis of Governance, Tokyo, 2005, 122-142.

Rhodes, P. J., Ancient Democracy and Modern Ideology, London, 2003.

Rich, J. W., "The supposed Roman manpower shortage of the later second century B.C.", Historia 32 (1983), 287-331.

Richard, J-C., "Patricians and Plebeians: The Origin of a Social Dichotomy", in K. A. Raaflaub (ed.) Social Struggles in Archaic Rome: New Perspectives on the Conflict of the Orders. Berkeley, 1986, 105-129.

Richardson, J. S., “The 'Commentariolum Petitionis'”, Historia 20 (1971), 436-442.

Richardson, J. S., “The Ownership of Roman land: Tiberius Gracchus and the Italians", JRS 70 (1980): 1-11.

Richardson, J., "The Roman Constitution. Review of A. Lintott: The Constitution of the Roman Republic" CR 52 (2002): 120-122.

Richardson, L., A New Topographical Dictionary of Ancient Rome, London, 1992.

Rickman, G., The Corn Supply of Ancient Rome, Oxford, 1980.

Riddle, J. M. (ed.), Tiberius Gracchus: Destroyer or Reformer of the Republic? Lexington, Massachusetts, 1970.

Riggsby, A. M. Crime and Community in Ancient Rome, Austin, 1999. 
Riggsby, A. M. "Review of Robert Morstein-Marx, Mass Oratory and Political Power in the Late Roman Republic", BMCR 2005.03.10

Robinson, A., “Cicero's use of the Gracchi in two speeches before the people", Athene e Roma 39 (1994), 71-76.

Robinson, E. W. (ed.), Ancient Greek Democracy: Readings and Sources Malden, MA, 2003.

Rogers, G. M., "Polybius was right", in H. M. Cotton and G. M. Rogers (eds.) Fergus Millar: Rome, the Greek World, and the East, Vol. I, The Roman Republic and the Augustan Revolution, Chapel Hill, 2002.

Roniger, L. and A. Günes-Ayata (eds.), Democracy, Clientelism and Civil Society, Boulder, Col., 1994.

Rose, P. "Cicero and the Rhetoric of Imperialism: Putting the Politics back into Political Rhetoric," Rhetorica 13 (1995): 359-399.

Rosenstein, N., “War, Failure, and Aristocratic Competition”. CPh 85 (1990a), 255-265.

Rosenstein, N., Imperatores Victi. Military Defeat and Aristocratic Competition in the Middle and Late Republic, Berkeley, 1990b.

Rosenstein, N., "Nobilitas and the political implications of military defeat", The Ancient History Bulletin 6 (1992), 117-126.

Rosenstein, N., "Competition and crisis in Mid-Republican Rome", Phoenix 47 (1993), 313-338. 
Rosenstein, N., "Sorting out the lot in Republican Rome", AJPh 116 (1995), 43-75.

Rosenstein, N., Rome at War: farms, families and death in the Middle Republic, Chapel Hill, 2004.

Rosenstein, N., "Review of T. Corey Brennan, The Praetorship in the Roman Republic", JRS 94 (2004), 234 f.

Rosenstein, N., C. Williamson and J. North, "Responses to W. V. Harris", CPh 85 (1990), 294-298.

Rosenstein, N., and R. Morstein-Marx (eds.), A Companion to the Roman Republic, Malden, MA., 2006.

Rosivach, V. J., "Caelius' adherence to the Caesarian cause", CW 74 (1980-81) 201-212.

Rotondi, G., Leges Publicae Populi Romani, Milan, 1922.

Rowe, G., "Review of M.H. Crawford (ed.): Roman Statutes,", JRS 87 (1997), 264-266.

Rudé, G., Ideology and Popular Protest, London, 1980.

Rudé, G., The Crowd in History, 1730-1848, 2nd ed., London, 1981.

Rundell, W. M. F., "Cicero and Clodius: The Question of Credibility", Historia, 28 (1979), 301-28.

Sage, E. T., "Cicero and the Agrarian Proposals of 63 BC", CJ 16 (1921): 230-236. 
Saikal, A. and A. Schnabel (eds.), Democratization in the Middle East: experiences, struggles, challenges, Tokyo, 2003.

Saller, R., Personal Patronage under the Early Roman Empire, Cambridge, 1982.

Saller, R., "Patronage and friendship in early imperial Rome: drawing the distinction", in A. Wallace-Hadrill (ed.), Patronage in Ancient Society, London, 1989, 49-62.

Salmon, E. T., Roman Colonization under the Republic, London, 1969.

Samons, L. J., II, What's Wrong with Democracy? From Athenian Practice to American Worship, Berkeley, 2004.

Ste. Croix, G. E. M. de, The Class Struggle in the Ancient Greek World: from the Archaic Age to the Arab Conquests, London, 1981.

Ste. Croix, G. E. M. de, Athenian Democratic Origins and other essays, D. Harvey and R. Parker (eds.), Oxford, 2004.

Sandberg, K., "The concilium plebis as a legislative body during the Republic", in U. Paananen (ed.) Senatus Populusque Romanus. Studies in Rome Republican Legislation, Helsinki, 1993, 74-96.

Sandberg, K., Magistrates and Assemblies: a Study of Legislative Practices in Republican Rome, Rome, 2001.

Savunen, L. "Debt Legislation in the Fourth Century BC", in U. Paananen (ed.), Senatus Populusque Romanus. Studies in Roman Republican Legislation, Helsinki, 1993, 143-159. 
Scheidel, W., "The Slave Population of Roman Italy: Speculation and Constraints", Topoi 91 (1999): 129-144.

Scheidel, W., Debating Roman Demography, Leiden, 2001.

Scheidel, W., "Germs for Rome", in C. Edwards and G. Woolf (eds.), Rome the Cosmopolis, Cambridge, 2003, 158-176.

Scheidel, W., “Human Mobility in Roman Italy, I: The Free Population”, JRS 94 (2004), 1-26.

Scheidel, W., "Human Mobility in Roman Italy, II: The Slave Population", JRS 95 (2005), 64-79.

Scheidel, W and S. von Reden (eds.), The Ancient Economy, Edinburgh, 2002.

Scheidel, W., "Roman population size: the logic of the debate", in: L. de Ligt and S. Northwood (eds.), People, land, and politics: demographic developments and the transformation of Roman Italy 300 BC - AD 14, Brill: Leiden, 2008, 17-70.

Schiller, A. A., Roman Law, The Hague, 1978.

Schofield, M., "Perceptions of the Roman Republic. Review of F. Millar: The Roman Republic in Political Thought", CR 54 (2004), 169-171.

Schumpeter, J., Capitalism, Socialism and Democracy, $4^{\text {th }}$ ed., London, 1954.

Scullard, H. H., From the Gracchi to Nero, London, 1959.

Scullard, H. H., Roman Politics 220-150 B.C., 2nd ed., Oxford, 1973. 
Scullard, H. H., Festivals and Ceremonies of the Roman Republic, London, 1981.

Seager, R., “Factio: Some Observations”, JRS 62 (1972a), 53-58.

Seager, R., "Cicero and the word popularis", CQ 66 (1972b), 328-338.

Seager, R., "Populares in Livy and the Livian tradition", CQ 71 (1977), 377-390.

Seager, R., "Sulla", ch. 6 in CAH II, vol. 9, 1994, 165-207.

Seager, R., “The Rise of Pompey”, CAH II, vol. 9, 1994, 208-228.

Seager, R., Pompey the Great: a political biography, 2nd ed., Oxford, 2002.

Shackleton Bailey, D. R., "Nobiles and Novi reconsidered", AJPh 107 (1986), 255-60.

Shapiro, I., The State of Democratic Theory, Princeton, 2003.

Shatzman, I., "The Roman general's authority over booty", Historia 21 (1972), 177-205.

Shatzman, I., Senatorial Wealth and Roman Politics, Brussels, 1975.

Shaw, B. D., “Debt in Sallust”, Latomus 34 (1975), 187-196.

Sherwin-White, A. N., “Violence in Roman Politics”, JRS 46 (1956), 1-9.

Sherwin-White, A. N., The Roman Citizenship, 2nd ed., Oxford, 1973.

Sherwin-White, A. N., “The Lex Repetundarum and the political ideas of Gaius Gracchus", JRS 72 (1982), 18-31.

Shochat, Y., Recruitment and the Programme of Tiberius Grachus, Brussels, 1980. 
Shotter, D., The Fall of the Roman Republic, London, 1994.

Skydsgaard, J. E., "Non-Slave Labour in Rural Italy during the Late Republic", in P. D. A. Garnsey (ed.) Non-Slave Labour in the GrecoRoman World, Cambridge, 1980, 65-72.

Sluiter, I. and R. M. Rosen (eds.), Free Speech in Classical Antiquity, Leiden, 2004

Smith, R. E., The Failure of the Roman Republic, Cambridge, 1955.

Smith, R. E., Cicero the Statesman, Cambridge, 1966.

Staveley, E. S., “The reform of the comitia centuriata”, AJPh. 74 (1953a), $1-33$.

Staveley, E. S., "The significance of the consular tribunate", JRS 43 (1953b), 30-36.

Staveley, E. S., "Cicero and the comitia centuriata", Historia 11 (1962), 299-314.

Staveley, E. S., Greek and Roman Voting and Elections, London, 1972.

Steinby, E. M. (ed.), Lexicon topographicum urbis Romae, 6 vols., Rome, 1993-2000.

Stewart, R., "Review of F. Millar: The Crowd in Rome in the Late Republic", The American Historical Review 104.4 (1999), 1359-1360.

Stockton, D. L., Cicero: A Political Biography, Oxford, 1971.

Stockton, D. L., The Gracchi, Oxford, 1979.

Stockton, D. L., Classical Athenian Democracy, Oxford, 1990. 
Sumner, G. V., "Aspects of the history of the comitia centuriata in the middle and late Republic", Athenaeum 40 (1962), 61-83.

Sumner, G. V., “Lex Aelia, Lex Fufia”, AJPh. 84 (1963), 337-358.

Sumner, G. V., "The legion and the centuriate organization", JRS 60 (1970), 66-78.

Suolahti, J., The Junior Officers of the Roman Army in the Republican Period, Helsinki, 1955.

Suolahti, J., The Roman Censors, Helsinki, 1963.

Syme, R., The Roman Revolution, Oxford, 1960 [1939].

Syme, R., “Ten Tribunes”, JRS 53 (1963), 55-60.

Syme, R., Sallust, Berkeley, 1964.

Syme, R., "A Roman post-mortem. An inquest on the fall of the Roman Republic", in Syme. Roman papers I. (ed. E. Badian), Oxford, 1979.

Syme, R., "Human rights and social status in ancient Rome", CQ 62 (1986-7), 37-41.

Talisse, R. B., Democracy After Liberalism: Pragmatism and Deliberative Politics, New York, 2005.

Tatum, W. J., "Another Look at the Spectators at the Roman Games." The Ancient History Bulletin 4 (1990), 104-7.

Tatum, W. J., The Patrician Tribune Publius Clodius Pulcher, Chapel Hill, 1999. 
Tatum, W. J., "Roman Democracy?", in R.K. Balot (ed.), A Companion to Greek and Roman Political Thought, Oxford, (forthcoming, 2009).

Taylor, L. R., Party Politics in the Age of Caesar, Berkeley, 1949.

Taylor, L. R., "The centuriate assembly before and after the reform", AJPh. 78 (1957), 337-354.

Taylor, L. R., The Voting Districts of the Roman Republic, Rome, 1960.

Taylor, L. R., "Freedmen and Freeborn in the Epitaphs of Imperial Rome", AJPh. 82 (1961), 113-132.

Taylor, L. R., “Forerunners of the Gracchi”, JRS 52 (1962), 19-27.

Taylor, L. R., Roman Voting Assemblies: From the Hannibalic War to the Dictatorship of Caesar, Ann Arbor, 1966.

Taylor, L. R. and R. T. Scott, "Seating space in the Roman senate and the senatores pedarii", TAPA 100 (1969), 529-582.

Todd, M. J., and G. Taylor (eds.), Democracy and Participation: Popular Protest and New Social Movements, London, 2004.

Toynbee, A. J., Hannibal's Legacy: The Hannibalic War's Effects on Roman Life, 2 vols., Oxford, 1965.

Treggiari, S., Roman Freedmen during the Late Republic., Oxford, 1969.

Treggiari, S., "Urban Labour in Rome: Mercennarii and Tabernarii", in P. D. A. Garnsey (ed.), Non-Slave Labour in the Greco-Roman World, Cambridge, 1980, 48-64. 
Treggiari, S., “Leges sine moribus”, The Ancient History Bulletin 3 (1994), $86-98$.

Tyrrell, W. B. “The Trial of C. Rabirius in 63 B.C.", Latomus 32 (1973), 285-300.

Tyrrell, W. B. A Legal and Historical Commentary to Cicero's Oratio pro C. Rabirio Perduellionis Reo, Amsterdam, 1978.

Vanderbroeck, P. J. J., Popular Leadership and Collective Behavior in the Late Roman Republic (ca. 80-50 B.C.), Amsterdam, 1987.

Vanhanen, T., Democratization: A comparative analysis of 170 countries, London, 2003.

Vasaly, A., Representations: Images of the World in Ciceronian Oratory, Berkeley, 1993.

Veyne, P., Le Pain et le Cirque, Paris, 1976.

Veyne, P., Bread and Circuses, (trans. B. Pearce), Harmondsworth, 1990.

Walbank, F. W., Polybius, Berkeley, 1972.

Walbank, F. W., "Polybius' perception of the one and the many", in I. Malkin and Z. W. Rubinsohn (eds.), Leaders and Masses in the Roman World. Studies in Honor of Zvi Yavetz, Leiden, 1995, 201-222.

Walbank, F. W., Polybius, Rome and the Hellenistic World. Essays and Reflections, Cambridge, 2002. 
Wallace-Hadrill, A., "Patronage in Roman Society: From Republic to Empire." in A. Wallace-Hadrill (ed.), Patronage in Ancient Society, London, 1989, 63-88.

Ward, A. M., Crassus and the Late Roman Republic, New York, 1977.

Ward, A. M., "How Democratic Was the Roman Republic?", New England Classical Journal, 31.2 (2004), 101-119.

Watson, A., Law Making in the Later Roman Republic, Oxford, 1974.

Weaver, P. R. C., Familia Caesaris: A Social Study of the Emperor's Freedmen and Slaves, Cambridge, 1972.

Weissman, R. F., "Commentary", in A. Molho, K. Raaflaub and J. Emlen (eds.), City-States in Classical Antiquity and Medieval Italy, Stuttgart, 1991, 347-349.

Wiedemann, T. E. J., Greek and Roman Slavery, London, 1981.

Wiedemann, T. E. J., “The Regularity of Manumission at Rome”, CQ 35 (1985), 162-175

Wiedemann, T. E. J., Slavery, Oxford, 1987.

Williamson, C., "The Roman Aristocracy and Positive Law", CPhil 85 (1990), 266-276.

Williamson, C., The Laws of the Roman People: Public Law in the Expansion and Decline of the Roman Republic, Ann Arbor, 2005.

Wirszubski, C., Libertas as a Political Idea at Rome during the Late Republic and Early Principate, Cambridge, 1960. 
Wiseman, T. P., “The ambitions of Quintus Cicero”, JRS 56 (1966), 108115.

Wiseman, T. P., “The census in the first century B.C.", JRS 59 (1969), 5975.

Wiseman, T. P., “The definition of 'Eques Romanus' in the late Republic and early Empire", Historia 19 (1970), 67-83.

Wiseman, T. P., New Men in the Roman Senate, 139 B.C.-A.D. 14, Oxford, 1971.

Wiseman, T. P., “Review of E. Badian, Publicans and Sinners”, Phoenix 27 (1973), 189-198.

Wiseman, T. P., “Democracy alla romana”, JRA 12 (1999), 537-540.

Wiseman, T. P., Roman Political Life: 90 B.C.-A.D. 69, Exeter, 1985.

Wiseman, T. P., “Review of F. Coarelli, Il Foro Romano II” JRS 76 (1986) 307-308.

Wiseman, T. P., "Campus Martius" in E. M. Steinby (ed.), Lexicon topographicum urbis Romae, vol. 1, Rome, 1993, 220-224

Wiseman, T. P., "The senate and the populares, 69-60 B.C.", ch 9 in CAH II vol. 9 (1994) 327-367.

Wiseman, T. P., "Caesar, Pompey and Rome”, ch. 10 in CAH II vol. 9, $1994,36-423$.

Wiseman, T. P., “Democracy alla romana”, JRA 12 (1999), 537-540. 
Wiseman, T. P., "Roman history and the ideological vacuum”, in T. P. Wiseman (ed.), Classics in Progress, Oxford, 2002, 285-310.

Wood, G. A. and C. Rudd, The Politics and Government of New Zealand, Dunedin, 2004.

Wood, N., Cicero's Social and Political Thought, Berkeley, 1991.

Yakobson, A., "Petitio et Largitio: popular participation in the centuriate assembly of the late Republic", JRS 82 (1992), 32-52.

Yakobson, A., "Secret ballot and its effects in the late Roman Republic", Hermes 123 (1995), 426-442.

Yakobson, A., “Mid-Republican Rome and Popular Politics. Review of R. F. Vishinia, State, Society and Popular Leaders in Mid-Republican Rome241-167 B.C." SCI 16 (1997): 152-158.

Yakobson, A., Elections and Electioneering in Rome: A Study in the Political System of the Late Republic, Stuttgart, 1999.

Yakobson, A., "Popular Power in the Roman Republic", in N. Rosenstein and R. Morstein-Marx (eds.), A Companion to the Roman Republic, Malden, MA., 2006, 383-400.

Yavetz, Z., "The living conditions of the urban plebs in Republican Rome", Latomus 17 (1958), 500-517.

Yavetz, Z., “The failure of Catiline's conspiracy”, Historia 12 (1963), 485499. 
Yavetz, Z., Plebs and Princeps, Oxford, 1969.

Yavetz, Z., Julius Caesar and his Public Image, London, 1983. 